


\section{HUMAN CAPITAL DEVELOPMENT IN SOUTH ASIA}

ACHIEVEMENTS, PROSPECTS, AND POLICY CHALLENGES 
(C) 2017 Asian Development Bank

6 ADB Avenue, Mandaluyong City, 1550 Metro Manila, Philippines

Tel +63 2632 4444; Fax +6326362444

www.adb.org

Some rights reserved. Published in 2017.

ISBN 978-92-9261-038-8 (print), 978-92-9261-039-5 (electronic)

Publication Stock No. TCS179082

http://dx.doi.org/10.22617/TCS179082

The views expressed in this publication are those of the authors and do not necessarily reflect the views and policies of the Asian Development Bank (ADB) or its Board of Governors or the governments they represent.

ADB does not guarantee the accuracy of the data included in this publication and accepts no responsibility for any consequence of their use. The mention of specific companies or products of manufacturers does not imply that they are endorsed or recommended by ADB in preference to others of a similar nature that are not mentioned.

By making any designation of or reference to a particular territory or geographic area, or by using the term "country" in this document, $A D B$ does not intend to make any judgments as to the legal or other status of any territory or area.

This work is available under the Creative Commons Attribution 3.0 IGO license (CC BY 3.0 IGO)

https://creativecommons.org/licenses/by/3.0/igo/. By using the content of this publication, you agree to be bound by the terms of this license. For attribution, translations, adaptations, and permissions, please read the provisions and terms of use at https://www.adb.org/terms-use\#openaccess.

This CC license does not apply to non-ADB copyright materials in this publication. If the material is attributed to another source, please contact the copyright owner or publisher of that source for permission to reproduce it. $A D B$ cannot be held liable for any claims that arise as a result of your use of the material.

Please contact pubsmarketing@adb.org if you have questions or comments with respect to content, or if you wish to obtain copyright permission for your intended use that does not fall within these terms, or for permission to use the ADB logo.

Notes:

In this publication, "\$” refers to US dollars.

ADB recognizes "China" as the People's Republic of China, "Korea" as the Republic of Korea, and "Vietnam" as Viet Nam. Corrigenda to ADB publications may be found at http://www.adb.org/publications/corrigenda. 


\section{CONTENTS}

Tables, Figures, and Boxes $v$

Acknowledgments vii

Abbreviations viii

$\begin{array}{ll}\text { Executive Summary ix } & \text { ix }\end{array}$

I. Overview 1

A. Objective and Scope 2

B. Organization of the Report 3

II. Human Capital Development and Economic Growth 5

A. Overview of Human Development, Structural Transformation,
and Income Growth

B. Role of Human Capital on Economic Development 14

C. Skills Development and Economic Growth 21

III. Achievements and Challenges in Education 27

A. School Enrollments and Educational Attainment 28

B. Quality of Education 33

C. National Education Policies and Institutions 44

IV. Labor Force and Skills 49

A. Evolution of Employment Structure and Skill Requirements 49

B. Technical and Vocational Education and Training Systems in South Asia 54

India $\quad 54$

Bangladesh 61

$\begin{array}{ll}\text { Nepal } & 62\end{array}$

Sri Lanka 63

C. Challenges to the Technical and Vocational Education and Training Systems in South Asia 65

Inputs $\quad 65$

$\begin{array}{ll}\text { Process } & 66\end{array}$

$\begin{array}{ll}\text { Outputs } & 68\end{array}$

V. Changes in Skill Demand and Supply and Wage Structure 69

A. Skill Upgrading, Wage Structure, and Skill Premium in Labor Markets 69

B. Micro Level Analysis of Skill Composition and Wage Structure 71 
Bangladesh $\quad 88$

$\begin{array}{ll}\text { Indonesia } & 92\end{array}$

C. Technology Change and Skill Demand by Enterprises in Asia 99

VI. Policy Recommendations for Human Capital Development 103

A. Access and Quality 103

1. Invest in upgrading and monitoring educational quality toward achieving better learning outcomes. 105

2. Narrow gender, geographical, and socioeconomic disparities in school attainment and outcomes.

3. Improve secondary and tertiary education to match the changing skill demand. 107

B. Skills, Employment, and Labor Markets

108

1. Boost the quality of training and skills development systems to meet industry standards and hasten job-skill matching.

108

2. Facilitate a favorable environment for skills development and training and improve public-private partnership.

3. Harness training and quality employment opportunities for all. 114

C. National Policies and Regional Cooperation

1. Design human capital development strategies that are coherent with the national development policy.

2. Pursue sustainable mechanisms for financing quality improvements in education and skills development.

3. Enhance regional cooperation for human development. 


\section{TABLES, FIGURES, AND BOXES}

Tables

1 Per Capita Gross Domestic Product 6

2 Human Development Indicators 10

3 Growth Accounting for Gross Domestic Product per Worker 17

4 Research and Development Model of Total Factor Productivity Growth 20

5 Program for the International Assessment of Adult Competencies $\begin{array}{ll}\text { Average Test Scores } & 23\end{array}$

6 Educational Attainment 30

7 Gender Parity Index by Level 32

8 Programme for International Student Assessment 36

9 Public Investment on Education 46

10 Employment Share of Industry Sector 50

11 Female Labor Force Participation Rates 53

12 Youth and Adult Unemployment Rates 54

13 Real Weekly Wage Changes for Full-Time Workers in India, 1994-2010 77

14 Relative Monthly Supply Changes for Full-Time Workers in India, 1994-2010 78

15 Inner Products of Changes in Wages with Changes in Supplies 79

16 Data Summary Statistics of Waged Workers in the Labor Force 84

17 Real Weekly Wage Changes for Full-Time Workers in Sri Lanka, 2000-2012 85

18 Relative Monthly Supply Changes of Employed Workers in Sri Lanka, 2000-2012 86

19 Inner Products of Changes in Wages with Changes in Supplies 88

20 Data Summary Statistics of Waged Workers in the Labor Force 90

21 Changes in Log Relative Demand for Male Workers 91

22 Data Summary Statistics of Workers in the Labor Force, 1990-2013 96

23 Real Monthly Wage Changes for Full-Time Workers in Indonesia, 1990-2013 97

24 Relative Monthly Supply Changes of Employed Workers, 1990-2013 98

25 Inner Products of Changes in Wages with Changes in Supplies 98

26 Descriptive Statistics: World Bank Enterprise Survey Data 100

27 Regression Results for Nonproduction Workers' Share in Employment 101

\section{Figures}

1 Per Capita Gross Domestic Product Growth 7

2 Output and Employment Structure 8

3 Global Competitiveness Index 12 
4 Health, Education, and Technological Readiness 13

5 Gross Enrollment Ratios $\quad 29$

6 Educational Attainment 33

7 Prevalence of Underweight Children 34

8 Mean Achievement Test Scores of Grade 5 and Grade 8 Students in Nepal by Subject and Region $\quad 37$

9 Class Size and Trained Teachers in Primary Schools 39

10 Distribution of Tertiary Students by Program 42

11 Expenditure on Tertiary Education by Source 45

12 Private Expenditure on Education by Level 47

13 Proportion of Secondary Students Enrolled in Technical and/or Vocational $\begin{array}{ll}\text { Education Programs } & 57\end{array}$

14 Labor Force with Vocational Training in India 58

15 Proportion of Companies Providing Formal In-Service Training 60

16 Trends in Wage Inequality in India $\quad 72$

17 Gini Coefficients in India $\quad 73$

18 Skill Premium in India $\quad 74$

19 Residual Wage Inequality in India $\quad 75$

20 Indexed Wage Inequality in Sri Lanka 80

21 Gini Coefficients in Sri Lanka 80

22 Skill Premium in Sri Lanka 81

23 Labor Force Participation Rate in Sri Lanka 83

24 Labor Force Participation Rate by Education 89

25 Trends in Wage Inequality in Indonesia 92

26 Gini Coefficients in Indonesia 93

27 Skill Premium in Indonesia 94

28 Residual Wage Inequality in Indonesia 95

29 Share of Nonproduction Workers 99

\section{BOXES}

1 A Virtuous Cycle of Human Development and Economic Growth in the Republic of Korea 11

2 Economic Impact of Workers' Remittances: Evidence from Developing Economies 15

3 Determinants of Skills in the Republic of Korea 24

4 What Makes a Good Teacher? 39

5 Higher Education and Employability in East Asia and Southeast Asia 42

6 Rates of Return to Education 47

7 Technical and Vocational Education and Training Systems in East Asia and Southeast Asia 55

8 Sequential Development of Education in the Republic of Korea 104

9 Linking Education to Jobs in Sri Lanka 107

10 Benefits of Investing in Information and Communication Technology for Education 115 


\section{ACKNOWLEDGMENTS}

This report was prepared by Jong-Wha Lee, Santosh Mehrotra, Ruth Francisco, and Dainn Wie for the Asian Development Bank's technical assistance for Strengthening KnowledgeDriven Development in South Asia (TA-7997 REG).

Insightful comments and suggestions from Mohiuddin Alamgir, Natalie Chun, Eiko Ezawa, Rana Hasan, Jeffrey Liang, Brajesh Panth, Tania Rajadel, Sofia Shakil, Diwesh Sharan, and Emma Veve, especially during the initial stages of the research, greatly helped improve the report and are gratefully acknowledged. This report also benefited from the outstanding research support by Hanol Lee and Eunbi Song. 


\section{ABBREVIATIONS}

ASER Annual Status of Education Report

PRC People's Republic of China

OECD Organisation for Economic Co-operation and Development

GNI gross national income

TVET technical and vocational education and training

GDP gross domestic product

ICT Information and communication technology

TFP total factor productivity

FDI foreign direct investment

R\&D research and development

PISA Programme for International Student Assessment

IALS International Adult Literacy Survey

PIAAC Programme for the International Assessment of Adult Competencies

UIS United Nations Educational, Scientific and Cultural Organization Institute for Statistics

MDGs Millennium Development Goals

UNESC United Nations Educational, Scientific and Cultural Organization

NCERT National Council of Educational Research and Training

NEREC National Education Research and Evaluation Center

SMEs Small and medium-sized enterprises

LFPR Labor force participation rate

ITIs industrial training institutes

NSDC National Skill Development Corporation

VTPs vocational training providers

IT information technology

MOL Ministry of Labor

TVEC Tertiary and Vocational Education Commission

UNEVOC UNESCO International Centre for Technical and Vocational Education and Training 


\section{EXECUTIVE SUMMARY}

T

his analytical study reviews the development of human capital in countries in South Asia, particularly in terms of education and skills achievement. It also analyzes the factors contributing to the differences in human development arising from policies and strategies for economic and human development pursued by these countries. It then compares the progress in education and skills development in these countries with those in other Asian economies, including the People's Republic of China, the Republic of Korea, and selected countries in Southeast Asia.

The expansion and upgrading of human capital play an important role in increasing employment, productivity, and income growth. However, in South Asia, education and skills remain the binding constraint. Raising the quality of education and skills of its workforce can play a critical role in catching up to the level of human and economic development of the People's Republic of China, the Republic of Korea, and more successful Southeast Asian economies.

Human capital is an important factor of economic growth in South Asian economies, along with physical capital and technology. The estimates of the growth accounting between 1981 and 2010 suggest that human capital contributed directly as a productive input of about $22 \%$ of annual gross domestic product per worker growth in India. During the same period, it contributed around 21\% in Bangladesh and 16\% in Sri Lanka.

Education and skills of the labor force also play a very important role in promoting the rates of technological progress and innovation in an economy when it moves up the value chain transitioning from simple to more sophisticated high-value products. This study emphasizes the significant role of schooling and skills on labor productivity and wages.

Although South Asia has made a tremendous progress in expanding access to schooling, especially at the primary and secondary levels, over the past decade, there are still millions of children who remain out of school. A significant number of them will remain uneducated for the rest of their lives. Substantial school disparities in access, participation, and completion across gender, income, and social groups still remain in countries in South Asia.

A greater focus on boosting the quality of education at all levels is needed. The quality of teachers is still low, particularly in rural areas. A large share of primary school graduates in South Asia lack basic numeracy and literacy skills. Additionally, students have limited access to post-primary education. Higher public and private investments in education are necessary to upgrade quality and reduce disparities in learning outcomes in South Asia. 
South Asia needs to keep up with the evolving skills requirement of the economic structural transformation process, as well as the rapidly growing youth workforce. A well-trained, relevant workforce is crucial to adequately support the economy and its transformation process. As these economies undergo early stages of structural transformation, they are now experiencing shortages of skilled workers.

Changes in demand and supply of skilled labor have also influenced wage inequality in South Asian economies. The expansion of skilled workers can match the pace of technological progress, it can also help reduce both skill-job mismatches and wage inequality.

In preparing the new entrants to the workforce, both capacity and quality constraints are needed to be addressed jointly by the public and private sectors in the region. Likewise, systemic problems are to be addressed to enable skills development institutions to upgrade the quality of skills they produce. More challenges specific to South Asia include rigidity in institutions, higher employment shares of the informal sector and small and medium-sized enterprises, gender inequality in labor market participation, and rapid increase in youth population.

Although skills development policies and technical and vocational education and training (TVET) systems in South Asia vary across countries, they share many weaknesses and problems, both in terms of access, inputs, and outputs. Girls, children from poor families, and rural residents are usually the ones that would benefit from vocational training. Teachers who are qualified and well-equipped to teach in TVET institutions are very limited in South Asia. Public resource allocations for skills training are inadequate, and there is very little private sector involvement. Due to the lack of involvement among potential employers, the TVET systems in South Asia rarely respond adequately to changes in the labor market. As a result, employability of graduates is low and widely varied.

The paper proposes nine policy actions toward developing a more productive, well-skilled, and relevant labor force for a modern, competitive economy:

\section{Implement human capital development strategies that are coherent with national} development policies, and relevant to changing demand. Mainstreaming education and skills development in national development policies is crucial to strengthen commitment and ensure that education and skills development could support economic development priorities toward overcoming challenges, including the changing industry demand and structural transformation, having high youth unemployment rates, growing youth population, and growing informal sector. Coordination of development policies on education and skills and training systems with other departments responsible for trade and industry development is important to ensure that they are coherent with the government's economic and labor policy directions. Conscious efforts toward promoting noneducation policies that support greater human development, such as policies on improving early childhood health and nutrition, creating a favorable business environment, and improving national infrastructure, are also important.

\section{Invest on upgrading and monitoring educational quality toward achieving better} learning outcomes. Upgrading teacher quality is a key to improving learning outcomes in South Asia. This region needs well-trained and qualified teachers who are able to help 
students develop cognitive and noncognitive competencies. Teachers should be wellequipped to engage students in classroom discussions, develop critical thinking, and effectively handle weak learners. Periodic assessment of teachers' capacity and student performance could help promote accountability among teachers toward addressing quality challenge. Strengthening school leadership and management in facilitating periodic assessments could help improve teacher quality. Aside from traditional monitoring and assessment channels, use of information and communication technology (ICT) can also be considered. With a transparent standard of recruitment and deployment system, long-term investment in teachers' continuous professional development is necessary for building a quality teaching force.

Broaden access to quality education and skills development across gender, regions, and social groups to narrow disparities in school attainment and outcomes. Countries must provide quality education to all learners in South Asia through equitably deploying trained teachers across regions and communities to reduce income gaps. Use of ICT tools to facilitate classroom and distance learning is also a promising mechanism for tackling geographical disparities in the quality of education and skills learning. Education scholarships and stipends for students from socially or economically disadvantaged families could also help reduce educational gaps across social groups. Empowering local governments and rural communities to demand and support better learning outcomes using their resources can contribute to reducing geographical disparities. Promoting adult education and alternative learning experiences can especially help mothers and students in communities where learning outcomes and school participation are particularly low.

Improve secondary and tertiary education to match changing skill demand. Secondary and tertiary schools are increasingly in demand to yield graduates with skills that are relevant to labor markets, and on par with industry standards. Encouraging greater partnership between educators and employers to facilitate the joint development of curriculum standards, internship, workforce exchange, as well as financing, is a promising way toward narrowing the gap between the skill supply and demand. Promoting the integration of internship programs and other practical learning experiences in secondary and tertiary curriculum could also ease greater production of graduates with employable skills.

Boost the quality of training and skills development systems to meet industry standards and hasten job-skill matching. Upgrading the quality of technical teachers is crucial in boosting the quality of skills development and training in South Asia. South Asian TVET systems should move from a supply-oriented to a more market demand-oriented training system that is relevant and responsive to the changing market demand. A law enabling joint certification between employers and the government could not only help raise the quality of TVET graduates in the region, but also encourage training providers to be more accountable with the quality of service they provide. Innovations such as competencybased training and vocational qualification frameworks can help establish appropriate quality standards in the workplace. While each actively plays its role in skills development, governments and private institutions in South Asian countries must work hand in hand toward expanding their capacity to provide training to their ever-growing workforce, enhancing the quality of workers and their skills to match demand, and harnessing quality employment for different skills levels. 
Facilitate a favorable environment for skills development and training, and improve public-private partnership. While strengthening its role and capacity for regulation, the government should shift the role of skills training to the private sector. Within a favorable regulatory environment, private training providers may be allowed to set their own fee levels and fields of concentration. Nonetheless, the government should play an active role in providing skills training where private solutions are either too costly or not found, such as in certain highly strategic skills, in remote geographical areas, or in the informal economy. Governments should encourage public-private partnership such as in-firm training, which remains very low in South Asia. Governments should also actively provide the public with information about current and future labor market requirements, training programs, as well as the performance of the public system.

Harness training and quality employment opportunities for all. Training and gendersensitive work environments must be fostered to encourage greater female labor participation. Skills training to specifically improve the productivity of the workforce in the informal sector, which continue to absorb the vast majority of new entrants, should be strengthened. Affordable, user-friendly ICT solutions should be considered as a tool for expanding the capacity for providing quality training and education and making it inclusive. Nonetheless, governments must initially improve their capacity to carefully formulate and adequately implement ICT strategies that are affordable and effective in reaching underserved, remote areas.

Pursue sustainable mechanisms for financing inclusive quality improvements in education and skills development. The public sector should effectively leverage its limited resources toward promoting greater private financing, and implementing cost-sharing mechanisms to expand greater access to quality education, especially at the postsecondary level. Governments can also help higher educational institutions in building their own capacity of raising additional resources. Affordable and effective mechanisms for financing quality improvements, such as competitive financing, training vouchers, and training levies, are essential for upgrading and expanding training and skills development. To generate a training fund, training levies could be collected from large and medium-sized firms. Integrating vocational education into the secondary schools curriculum, and providing stipends to cover costs other than tuition fee could encourage more students from poor families to stay in school and pursue vocational education.

Forge closer regional cooperation for human development. Many of the challenges on education and skills development are common across South Asia, as well as in other parts of Asia. Development partners, such as the Asian Development Bank, could leverage their resources toward greater knowledge sharing, teacher training, expert and student exchanges, student assessment, curriculum development, research collaborations, and technology-sharing to promote school productivity and effective learning across Asian countries. Countries in South Asia can learn from the experience of countries in East Asia and Southeast Asia in skills upgrading, industrial development, and strategic financing. In addition, promoting greater mobility of students and labor with and across countries, and improving flexibility of labor markets also offer great promise in reducing wage disparities and skills development, as well as making allocation of skilled workers more efficiently across economies. 
Within the framework of these broad policy recommendations, policies for boosting the quality of human development at the national and local levels must be more carefully and systematically designed, implemented, and evaluated. More systematic studies must be conducted to design broad-based and well-targeted interventions to encourage adequate investments for upgrading the quality of education and skills development. 



\section{OVERVIEW}

$\mathrm{H}$

uman development is widely considered to be a crucial factor for industrialization and modernization of countries. Recent studies have emphasized the significant importance of human capital, particularly that attained through education and skills, for sustained long-term growth (Lucas 1988; and Mankiw, Romer, and Weil 1992). An abundance of well-educated people goes along with high level of labor productivity. It implies greater human capabilities to acquire advanced technology from developed countries. Improving human capital can create a virtuous circle since it facilitates technology adaptation and progress. In turn, technological progress induces higher demand for skills.

Countries across Asia have demonstrated steady but different rates of progress in economic and human development over the last century, particularly after World War II. Significant improvements in both the quantity and quality of their labor forces have raised productivity and allowed for expansion, especially of their industry and service sectors, and therefore, contributed to economic growth. The average school attainment of the working-age population has increased at a faster pace in East Asia and Southeast Asia compared with South Asia (Barro and Lee 2013). Overall, East Asian and Southeast Asian economies have shown better performance in terms of human development than South Asian economies. The People's Republic of China (PRC) and the Republic of Korea are considered as exceptional cases showing unprecedented improvements. Significant changes in rates of returns to education, skill premium, and wage inequality have also occurred. Although rising inequality has been observed in some of these economies, most economies have been successful in reducing poverty while raising per capita income (Asian Development Bank [ADB] 2012a).

Studies have also highlighted differences between the two regions regarding workplace training and lifelong learning that enable workers to adjust to an increasingly rapid progress in technology (Maclean et al. 2013; Organisation for Economic Co-operation and Development [OECD] 2012a, 2012b). As economies in Asia continue to progress, demand is rising particularly for workers with secondary education and better skills. More successful economies in Asia, such as the Republic of Korea, have consciously invested heavily in human capital as a major strategy to move up the value chain, and to move toward a knowledge economy with higher per capita income.

In South Asia, education and skills remain the third binding constraint after transport and energy. In addition to addressing transport and energy challenges, it is crucial for South Asian countries to raise the quality of education and skills of its workforce to avoid stagnating at their current income levels and catch up a level of economic and human development of the PRC, the Republic of Korea, and more successful Southeast Asian economies. 


\section{A. Objective and Scope}

This analytical study reviews the human capital development in South Asia, particularly in terms of education and skills achievement, and compares it with that in other Asian economies, including the PRC, the Republic of Korea, and selected Southeast Asian countries to analyze the factors contributing to the differences in human development arising from economic and human development policies and strategies that the countries have pursued.

It relies on existing census and survey data on population and labor force in reviewing the expansion of labor force and progress in education over the last 5 decades, covering Bangladesh, India, Nepal, and Sri Lanka in South Asia. India and Sri Lanka currently belong to a group of lower middle-income economies, while Bangladesh and Nepal belong to that of low-income economies.' For comparison, the study will also cover Asian economies with different levels of development, including three lower middle-income economies: Indonesia, the Philippines, and Viet Nam; two upper middle-income economies: Malaysia and the PRC; and a high-income economy, the Republic of Korea, which will serve mainly as a reference point.

The analysis highlights the similarities and differences in educational and skills development trajectory across countries, and its implications on economic performance. It also identifies factors that have contributed to the different human capital and economic growth trends in these economies, with a focus on education and labor productivity trends. It draws policy lessons and insights based on the past experience of other successful Asian economies to guide future direction of the economies in South Asia in terms of strategically pursuing human capital investments that will allow them to move up the value chain, and therefore attain and sustain higher economic growth rates.

Human capital accumulation changes the distribution of earnings across individuals with different skills, thereby affecting income inequality in an economy. This study investigates how the changes in supply and demand of skilled workers have influenced wage inequality in South Asian economies by using micro-level data. It highlights the implications of technology development for skilled labor demand and wage inequality.

While human capital is a multidimensional concept covering a set of health- and education-related characteristics that contribute to worker productivity, this report focuses largely on the quantity and quality of education, skills training, and skills of the labor force at the national level, and, to some extent, at the regional level. ${ }^{2}$ Health and other important aspects of human capital are beyond the scope of this report.

\footnotetext{
According to the World Bank's classification, low-income economies are those with a gross national income (GNI) per capita, calculated using the World Bank Atlas method, of $\$ 1,045$ or less in 2013; middle-income economies are those with a $\mathrm{GNI}$ per capita of more than $\$ 1,045$ but less than $\$ 12,746$; high-income economies are those with a GNI per capita of $\$ 12,746$ or more. Lower middle-income and upper middle-income economies are separated at a GNI per capita of \$4,125 (http://data.worldbank.org/about/country-and-lendinggroups).

2 According to human capital theory developed by Becker (1964) and Mincer (1974), human capital refers to all the attributes of workers which can be accumulated by investment and used as a means of production, similar to physical capital.
} 
Different in terms of level and rate of development stages, as well as resource endowments, the numerous and diverse issues that confront the economies in South Asia are best tackled in country-specific contexts. This comparative report focuses on tackling major human capital development achievements and broad-based challenges that are common and relevant to most countries, and presents policy options for addressing these challenges. Policy insights from micro level analyses using data from labor force and enterprise surveys in South Asian countries, as well as in selected Southeast Asian economies with available data for comparison, are also discussed. Specific policy issues and challenges that are best addressed through an in-depth case study or impact evaluation are beyond the scope of this study.

\section{B. Organization of the Report}

The rest of the report is organized into thematic sections. Section II reviews and compares the past and present economic, institutional, and human development in South Asia. With selected Southeast Asian countries, the PRC, and the Republic of Korea as references, it also describes the remaining high-level policy challenges that may either constrain or enable continued human and economic development across countries. This section also discusses the link between human capital development and economic growth, and empirically assesses the contribution of human capital, measured by educational attainment and skills of adult population, on labor productivity growth.

Section III highlights the different trajectories of human capital development across economies. It looks at the changes in school enrollments and educational attainment, as well as the gaps in access to education, and the quality of educational output and its determinants. This section also reviews the policies pursued by these countries that contributed to these changes. Drawing from the successes of the PRC and the Republic of Korea in building human capital mainly through formal education toward meeting the emerging global demands, this section also highlights future policy options for economies in South Asia. It also presents some lessons on how the Republic of Korea has been able to make an effective transition from an agricultural economy to an industrialized economy, and then to a knowledge economy within a relatively short period of time.

Section IV reviews and compares the evolution of employment structure and skill requirements in South Asia, and as well as other countries in East Asia and Southeast Asia. It also tackles the existing technical and vocational education and training (TVET) systems in South Asia, and highlights the weaknesses and challenges within and across countries, especially in terms of the employability of new workers, in light of the rising demand for skilled workers for sustained economic growth. It also reviews those in the PRC, Indonesia, the Republic of Korea, Malaysia, the Philippines, and Viet Nam, and highlights the important strategies that these countries have pursued along with other lessons that are useful for South Asian countries.

Section $\vee$ investigates the changes in demand and supply of skilled workers and their impact on wage inequality across economies, and by educational level within each economy. It discusses the implications of technological development for labor demand changes and wage inequality in these economies. Using data from national surveys of 
labor force, it examines the changes in labor supply and demand and their influences on wage structure in three South Asian economies with available data-Bangladesh, India, and Sri Lanka-and Indonesia for comparison. Additionally, using firm-level data from the World Bank's Enterprise Surveys, it discusses whether technological change of these firms is related to research and development expenditures or foreign direct investment in South Asia and other Asian economies.

Section VI summarizes and concludes by reiterating key high-level policy directions related to skills development, and labor and employment based on the analysis presented in previous sections. 


\section{HUMAN CAPITAL DEVELOPMENT AND ECONOMIC GROWTH}

\section{Highlights}

- The expansion and upgrading of human capital, a key factor for promoting productivity and technological progress in economic growth, are important for sustaining the economic growth of South Asian countries.

- Greater and better quality education, which contributes significantly to the development of cognitive skills, plays an important role in increasing employment, productivity, and income growth.

- Continuous development of skills through pre-employment and on-the-job training is critical to sustaining growth in employment and labor productivity.

There has been significant progress in economic development, structural transformation, and human development in South Asian economies over the past decades. This section reviews past and present economic and human development conditions in South Asia, and compares them with those in selected Southeast Asian countries, the People's Republic of China (PRC), and the Republic of Korea as reference points, it also describes the remaining high-level policy challenges that may either constrain or enable continued human and economic development across countries.

An abundance of well-educated and better-skilled workers boosts productivity, increases returns on investment, and facilitates technological adaption and innovation. This section also reviews the link between human capital development and economic growth, and empirically assesses the contribution of human capital, measured by educational attainment of adult population, on labor productivity growth in South Asian and Southeast Asian economies. It also analyzes the role of skills development on productivity growth.

\section{A. Overview of Human Development, Structural Transformation, and Income Growth}

Table 1 compares the per capita income across South Asian countries and other Asian economies over the last 5 decades. It shows that, while the four South Asian countries started with comparable income levels in the 1960s, their income levels started to diverge between 1960 and 1990 as their growth rates varied (Figure 1). Experiencing a much faster economic growth during 1960-1990, India and Sri Lanka achieved an income level that is two to three times higher than that in Bangladesh and Nepal by 1990. From then on, 
economic growth in Bangladesh started to keep pace with that in India and Sri Lanka. Nonetheless, Bangladesh remained a low-income economy, along with Nepal, while India and Sri Lanka are now considered lower middle-income economies.

Although initially lower than most Southeast Asian economies, the per capita incomes of South Asian economies were higher than the PRC in the 1960s. However, between 1960 and 1990, the PRC's per capita income grew at a pace faster than South Asian economies. In the 1990s, although the PRC's level of income remained lower than Sri Lanka's income, with its economic growth doubling between 1990 and 2013, the PRC managed to surpass the per capita income not only of Sri Lanka, but also that of Indonesia and the Philippines. The PRC is now considered an upper middle-income economy.

\section{Table 1: Per Capita Gross Domestic Product}

\begin{tabular}{|c|c|c|c|c|c|c|}
\hline \multirow[b]{2}{*}{ Region and Country } & \multicolumn{3}{|c|}{$\begin{array}{c}\text { Level } \\
\text { (in 2005\$ constant prices) }\end{array}$} & \multicolumn{3}{|c|}{ Annual Growth (\%) } \\
\hline & 1960 & 1990 & 2013 & 1960-2013 & 1960-1990 & 1990-2013 \\
\hline \multicolumn{7}{|l|}{ South Asia } \\
\hline Bangladesh & 253 & 270 & 621 & 1.7 & 0.2 & 3.6 \\
\hline India & 228 & 403 & 1,165 & 3.1 & 1.9 & 4.6 \\
\hline Nepal & 178 & 233 & 409 & 1.6 & 0.9 & 2.4 \\
\hline Sri Lanka & 337 & 710 & 2,004 & 3.4 & 2.5 & 4.5 \\
\hline \multicolumn{7}{|l|}{ Other Asian countries } \\
\hline China, People's Rep. of & 121 & 463 & 3,583 & 6.4 & 4.5 & 8.9 \\
\hline Indonesia & 286 & 840 & 1,810 & 3.5 & 3.6 & 3.3 \\
\hline Korea, Rep. of & 1,107 & 8,829 & 23,893 & 5.8 & 6.9 & 4.3 \\
\hline Malaysia & 986 & 3,147 & 6,998 & 3.7 & 3.9 & 3.5 \\
\hline Philippines & 696 & 1,002 & 1,581 & 1.5 & 1.2 & 2.0 \\
\hline Singapore & 2,530 & 16,554 & 36,898 & 5.1 & 6.3 & 3.5 \\
\hline Thailand & $437^{a}$ & 1,572 & 3,438 & $4.3^{b}$ & $5.1^{c}$ & 3.4 \\
\hline Viet Nam & $263^{d}$ & 301 & 1,029 & $4.7^{e}$ & $3.4^{f}$ & 5.3 \\
\hline
\end{tabular}

a Reflects data for 1965.

b Reflects data from 1965 to 2013.

c Reflects data from 1965 to 1990.

d Reflects data for 1984.

e Reflects data from 1984 to 2013.

${ }^{f}$ Reflects data from 1984 to 1990.

Source: World Bank. 2014. World Development Indicators Online. http://databank.worldbank.org (accessed 24 December 2014).

The conditional convergence of income theory suggests that, relative to a country with an income level that is initially closer to its steady-state or long-run potential level, a country with a relatively low income will grow faster (Barro and Sala-i-Martin 1992). The gap between an economy's initial income and its steady-state income level is proportional to the gap between the stock of both its physical and human capital and technical efficiency 
from their long-run levels. A larger gap implies a greater or a more rapid catch-up through higher rates of capital accumulation and diffusion of technology from more technically advanced economies. Therefore, the lower the initial level of per capita income relative to its steady-state, the higher the subsequent growth tends to be.

In contrast to the prediction of convergence theory, although they started off poor, South Asian economies showed a slower growth in per capita income during 1960-1990, compared with their richer counterparts in Southeast Asia (Figure 1). Again, starting at a lower income level in the 1990s, the South Asian economies only managed to keep pace with the growth in Southeast economies. This suggests that structural characteristics as well as policy factors, rather than initial income, have played a greater role in determining the income growth in these Asian economies.

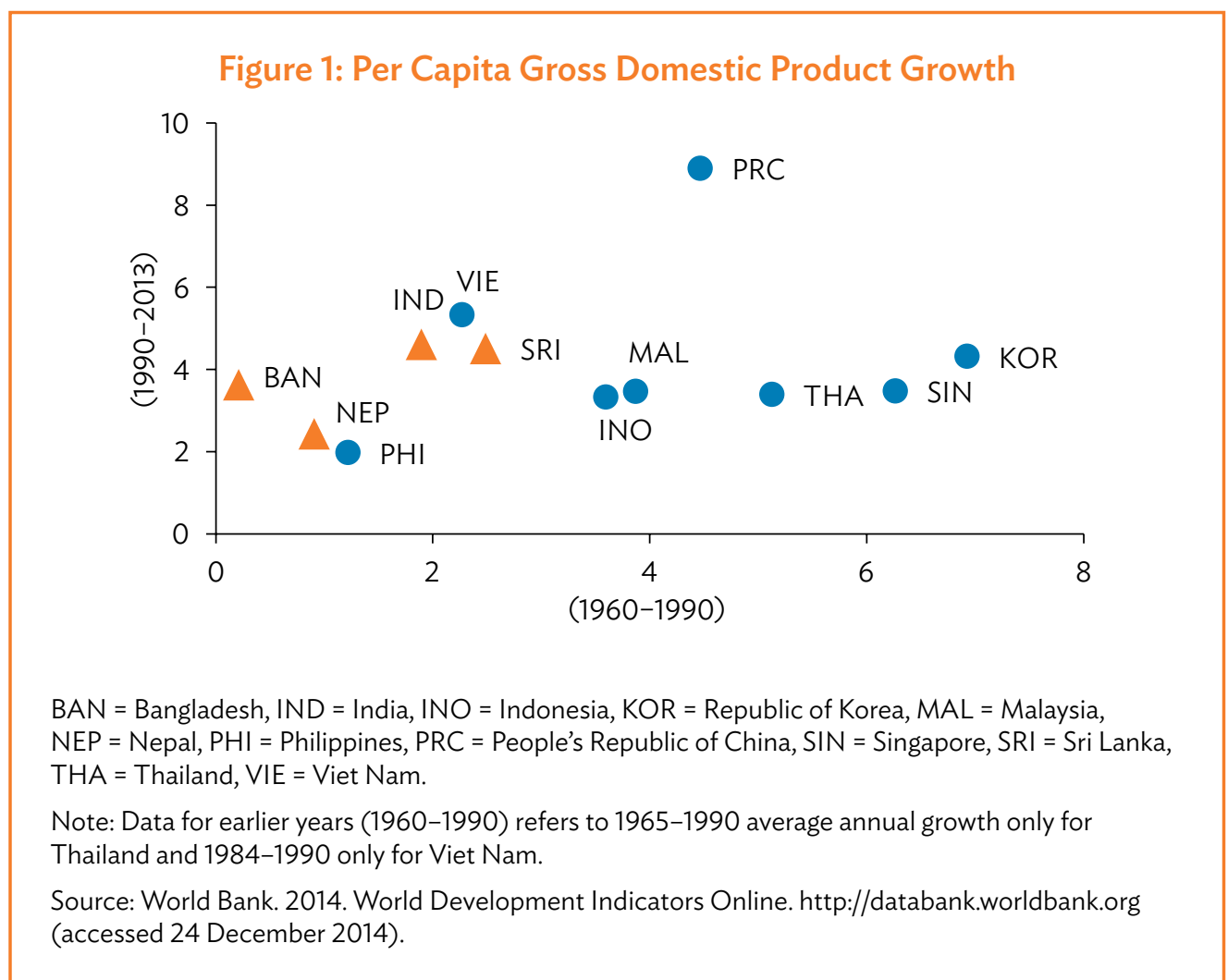

For South Asian economies to catch up and achieve a level of development that is comparable with that in the PRC, the Republic of Korea, and Southeast Asia, a faster growth rate would be required in the coming decades. This is why it is important for South Asia to study and learn from the early industrialization experience of the PRC, the Republic of Korea, and Southeast Asia, and build up their catch-up strategy. Specifically, understanding the role of human and physical capital, technology, as well as manufacturing and trade in driving economic growth in other more successful Asian economies could help guide economic policies in South Asia. 
Figure 2 shows the broad changes in the structure of economies in South Asia and other parts of Asia between 1980 and 2013. It depicts a general shift toward greater production and employment in the nonfarm sectors. The share of the nonfarm sectors to total output expanded by an average of 19 percentage points in South Asia during this period. This is higher than in the Republic of Korea (12.8 percentage points) and most Southeast Asian economies (excluding Viet Nam-21 percentage points), but slightly lower than in the PRC (20.2 percentage points).

\section{Figure 2: Output and Employment Structure}

Share in Output (\%)

South Asia

$\llbracket$ Agriculture $\backsim$ Industry $₫$ Services

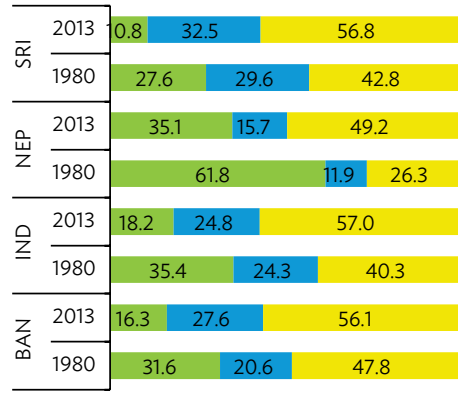

Other Asian countries

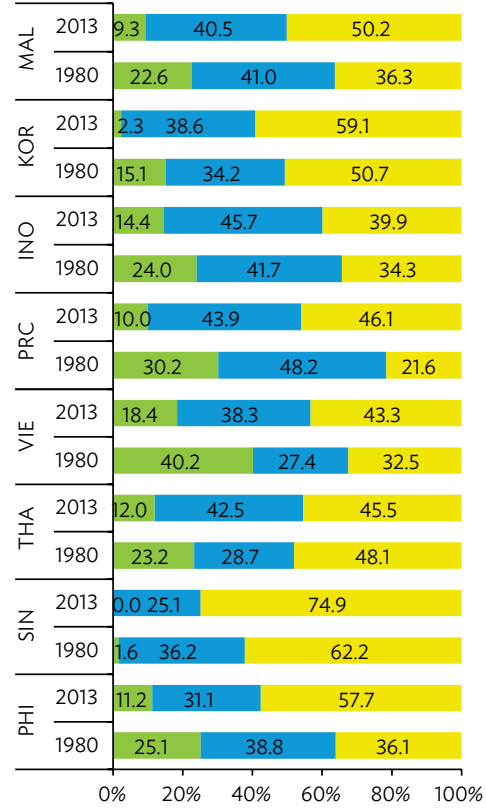

\section{Share in Employment (\%)}

$\llbracket$ Agriculture $\|$ Industry $₫$ Services

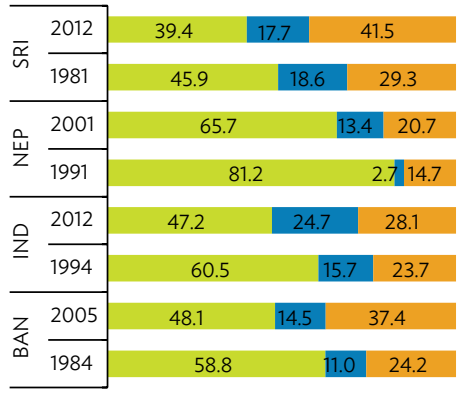

BAN = Bangladesh, IND = India, INO = Indonesia, $K O R=$ Republic of Korea, MAL = Malaysia, NEP = Nepal, $\mathrm{PHI}=$ Philippines, $\mathrm{PRC}=$ People's Republic of China, $\mathrm{SRI}=$ Sri Lanka, $\mathrm{THA}=$ Thailand, $\mathrm{VIE}=$ Viet Nam.

Sources: World Bank. 2014. World Development Indicators Online. http://databank.worldbank.org (accessed 24 December 2014); Groningen Growth and Development Centre 10-Sector Database. http://www.rug.nl/research/ggdc/data/10-sector-database (accessed 30 May 2014). 
The service sector accounted for most of the expansion in South Asia's nonfarm sector, especially in India, where the industry sector's share in total output only increased marginally during the period (i.e., by 0.5 percentage points), and in Nepal. This was also the case in some economies in Southeast Asia, including Malaysia, the Philippines, and Thailand, and the PRC where the share of the industry sector to total output even narrowed during the period. In contrast, the services sector's share to total output contracted (by 2.6 percentage points) during the period, while the industry sector's share expanded by 13.9 percentage points. In the Republic of Korea and Indonesia, the expansion of both nonfarm sectors during the period was more or less similar or close to each other.

The transformations confirm the stylized patterns of structural change in the previous studies (see the survey by Herrendorf et al. 2013). Increase in gross domestic product (GDP) per capita is associated with decreases in employment and value-added shares for agriculture, and increases in employment and value-added shares for services. The manufacturing employment and value-added shares show hump-shaped changes.

On the employment side, expansions in the share of nonfarm jobs were similarly observed, but at a rate that was disproportionate to those observed in the output side (Figure 2). In South Asia, the expansion in the share of nonfarm jobs was lower than that in output across all countries. Specifically, the share of nonfarm sector to total employment expanded by an average of only 11.5 percentage points in South Asia, or less than $40 \%$ or 7.5 percentage points lower than the expansion in nonfarm sector's share to total output. In contrast, the expansion of the share of nonfarm jobs in Southeast Asia (average of 19.9 percentage points) exceeded the expansion of nonfarm output's share by an average of almost $68 \%$ or 8 percentage points. This was similarly observed in the PRC and the Republic of Korea during the period. These suggest that between 1980 and 2013, the output growth and structural shift in South Asia was relatively less labor-intensive than in the PRC, the Republic of Korea, and most of South Asia (except Singapore).

In India and Nepal, more than two-thirds of the expansion in nonfarm jobs was in the industry sector and not in the services sector, which accounts for most of the growth in output.

Among others, the expansion of a labor-intensive industry sector (mainly manufacturing) in the 1950s played an important role in the economic and human capital development of the PRC and the Republic of Korea. In recent decades, the role of labor-intensive services sector in growth and job creation has been increasing not only in the PRC and the Republic of Korea but also in other Southeast Asian countries (Figure 2).

Table 2 provides a simple cross-country comparison in terms of some basic indicators of human development across four South Asian countries and selected East Asian and Southeast Asian economies with different income levels. Since the 1980s, all economies have made notable progress in human development, both in terms of increasing life expectancy and improving adult literacy rate.

Starting at different initial levels, rates of progress in each indicator also vary across economies. 
Table 2: Human Development Indicators

\begin{tabular}{|c|c|c|c|c|c|c|}
\hline \multirow[b]{2}{*}{ Region and Country } & \multicolumn{3}{|c|}{$\begin{array}{l}\text { Life Expectancy at Birth } \\
\text { (years) }\end{array}$} & \multicolumn{3}{|c|}{$\begin{array}{l}\text { Literacy Rate, Adult Total } \\
\text { (\% of people ages } 15 \text { and } \\
\text { over) }\end{array}$} \\
\hline & 1980 & 2000 & $\begin{array}{c}2012 \\
\text { or Latest }\end{array}$ & 1980 & 2000 & $\begin{array}{c}2012 \\
\text { or Latest }\end{array}$ \\
\hline \multicolumn{7}{|l|}{ South Asia } \\
\hline Bangladesh & 54.9 & 65.3 & 70.3 & 29.2 & 47.5 & 58.8 \\
\hline India & 55.4 & 62.2 & 66.2 & 40.8 & 61.0 & 62.8 \\
\hline Nepal & 47.7 & 62.0 & 68.0 & 20.6 & 48.6 & 57.4 \\
\hline Sri Lanka & 68.3 & 71.2 & 74.1 & 86.8 & 90.7 & 91.2 \\
\hline \multicolumn{7}{|l|}{ Other Asian countries } \\
\hline China, People's Rep. of & 67.0 & 72.1 & 75.2 & 65.5 & 90.9 & 95.1 \\
\hline Indonesia & 58.6 & 67.3 & 70.6 & 67.3 & 90.4 & 92.8 \\
\hline Korea, Rep. of & 65.8 & 75.8 & 81.4 & - & - & - \\
\hline Malaysia & 68.1 & 72.9 & 74.8 & 69.5 & 88.7 & 93.1 \\
\hline Philippines & 62.2 & 66.8 & 68.6 & 83.3 & 92.6 & 95.4 \\
\hline Singapore & 72.0 & 78.1 & 82.1 & 82.9 & 92.6 & 96.4 \\
\hline Thailand & 64.2 & 70.9 & 74.2 & 88.0 & 92.7 & 96.4 \\
\hline Viet Nam & 67.4 & 73.6 & 75.6 & - & 90.2 & 93.5 \\
\hline
\end{tabular}

- = data not available.

Source: World Bank. 2014. World Development Indicators Online. http://databank.worldbank.org (accessed 24 December 2014).

For instance, the average life expectancy at birth in Nepal increased from 1980 to 2012 by over 20 years or equivalent to almost $43 \%$ of its level in 1980 . In contrast, during the same period, the average life expectancy at birth in Sri Lanka-the highest among the four South Asian countries-increased by 5.8 years or equivalent to only $8.4 \%$ of its initial level. Nonetheless, many countries in East Asia and Southeast Asia, such as the PRC, the Republic of Korea, Malaysia, and Viet Nam having lower average life expectancy at birth than Sri Lanka in the 1980s, have surpassed Sri Lanka's performance.

A similar pattern can be observed in terms of literacy and educational attainment. This simply illustrates that other factors beyond the initial human development level matter in achieving better human development. Understanding these factors is important in narrowing human development gaps across countries, especially in South Asian countries with low levels of human development.

Another key challenge that needs to be addressed is the gender gap in human development. Currently, the gender gap in adult literacy rates remains above 20 percentage points in India and Nepal. The next section will discuss in detail the gender gap in education in South Asia. Addressing health and education challenges have implications to increasing a country's productivity and sustaining income growth. Along with institutions, infrastructure, and macroeconomic environment, health and primary education are basic requirements for development and competitiveness (Schwab and Sala-i-Martín 2014). These mutually enforcing factors are important, especially to the countries that are in the early stages of economic development. As they move to higher levels of development, efficiency enhancers such as higher education and training, goods and labor market efficiency, and technology readiness, and innovation and sophistication factors become more important. 
In East Asia, the rapid expansion of human capability is an integral element in achieving rapid economic growth (Drèze and Sen 2013). The quantity and quality of education received by the workforce allowed them to adapt to more advanced production processes and techniques, which in turn increases their production efficiency. Box 1 discusses how better-educated labor force enabled the growth and expansion of the Republic of Korea's export industry.

\section{Box 1: A Virtuous Cycle of Human Development and Economic Growth in the Republic of Korea}

Economic growth and human development have a two-way relationship. An outcome of economic growth, human capital development is also a contributing factor for growth, indicating a virtuous cycle. Exemplifying this virtuous cycle is the Republic of Korea, along with the People's Republic of China and Singapore.

Accumulating a well-educated labor force, as well as having high savings and investment ratios and well-directed export-oriented development strategies, the Republic of Korea has been successful in sustaining economic growth over the last half a century. A number of studies have suggested that the active enforcement of the Republic of Korea's comprehensive trade reforms and export promotion policies, such as direct export subsidies and tax incentives, since the regime of President Park Chung-hee in the 1960s also favored the shift from an inward-oriented to an export-oriented economy. Other policies, such as currency devaluation and foreign capital promotion, were also implemented to reduce bias against export industries and augment domestic capital.

Having an abundant supply of well-educated labor force enabled the Republic of Korea to enhance its labor productivity and promote competitiveness of its labor-intensive manufacturing industry in the 1960s and 1970s. Highly educated labor force enabled the Republic of Korea to absorb and further adapt advanced foreign technology, allowing it to invest in research and development and upgrade the level of sophistication of its industrial technologies.

Alongside sustaining economic progress, the Republic of Korea also achieved a rapid expansion and upgrading of education. Behind this was its deliberate and steady investment on education even before the early period of its economic takeoff. As early as 1960, the Republic of Korea had accumulated a substantial stock of human capital. About $56 \%$ of its population had received some primary education, and $20 \%$ had some secondary education, surpassing the attainment of most developing countries. Over the next 3 decades since then, the Republic of Korea experienced an unprecedented rate of educational growth-adding almost 6 years in its school attainment-as demand for higher education also increased with income, while public investment in education remained high. Better income allowed Koreans to fulfill their desire for a better social status.

Besides strong social motivations, the Republic of Korea's export-oriented development strategy also contributed to educational growth. The strong performance of labor-intensive export industries in the early stages of its development promised strong growth in wage and employment, thereby stimulating higher demand for education.

Because of the country's pursuit of outward-looking development strategy, there had been more incentives to acquire education higher than the level needed in prevailing industries compared with inward-looking economies. As the outward-looking economy is exposed to global competition, it needs to change its industrial and employment structures. To meet new requirements from more technologically advanced and profitable areas, investment in education is necessary. This results in a continuous increase in demand for further education.

Sources: Ranis and Stewart 2006; Suri et al. 2011; Chung 2011; Lee 2003. 
A 2014 report on the global competitiveness of 144 economies worldwide (Schwab and Sala-i-Martín 2014) highlights the importance of these factors that are mutually enforcing to determine a country's productivity across different stages of development. Using them as the basis for assessing countries' global competitiveness and ranking, the report ranks the more progressive economies in Asia at the upper third, headed by Singapore at second place (Figure 3). It is followed by other East Asian and Southeast Asian economies: Malaysia (20th place), the Republic of Korea (26th), the PRC (28th), Thailand (31st), Indonesia (34th), the Philippines (52nd), and Viet Nam (68th). In contrast, South Asian economies were lower in the rankings. India is at 71st place (lower than in 2013-2014: 60th place), followed shortly by Sri Lanka (73rd), while the two low-income economiesBangladesh (109th) and Nepal (102nd) - ranked squarely at the bottom third.

Since these factors are mutually enforcing, weakness in one pillar has negative consequences in others. For instance, a strong innovation capacity requires sufficient financing for research and development, including a workforce that is healthy, well-educated, well-trained, and adept at absorbing new technologies, among others (Schwab and Sala-i-Martín 2013). Meanwhile, efficiency in the goods and labor markets requires well-functioning institutions, a stable macro environment, and extensive and efficient infrastructure. As expected, countries with a higher level of development perform well in most of these development pillars; therefore, these countries tend to score better overall as shown in Figure 3.

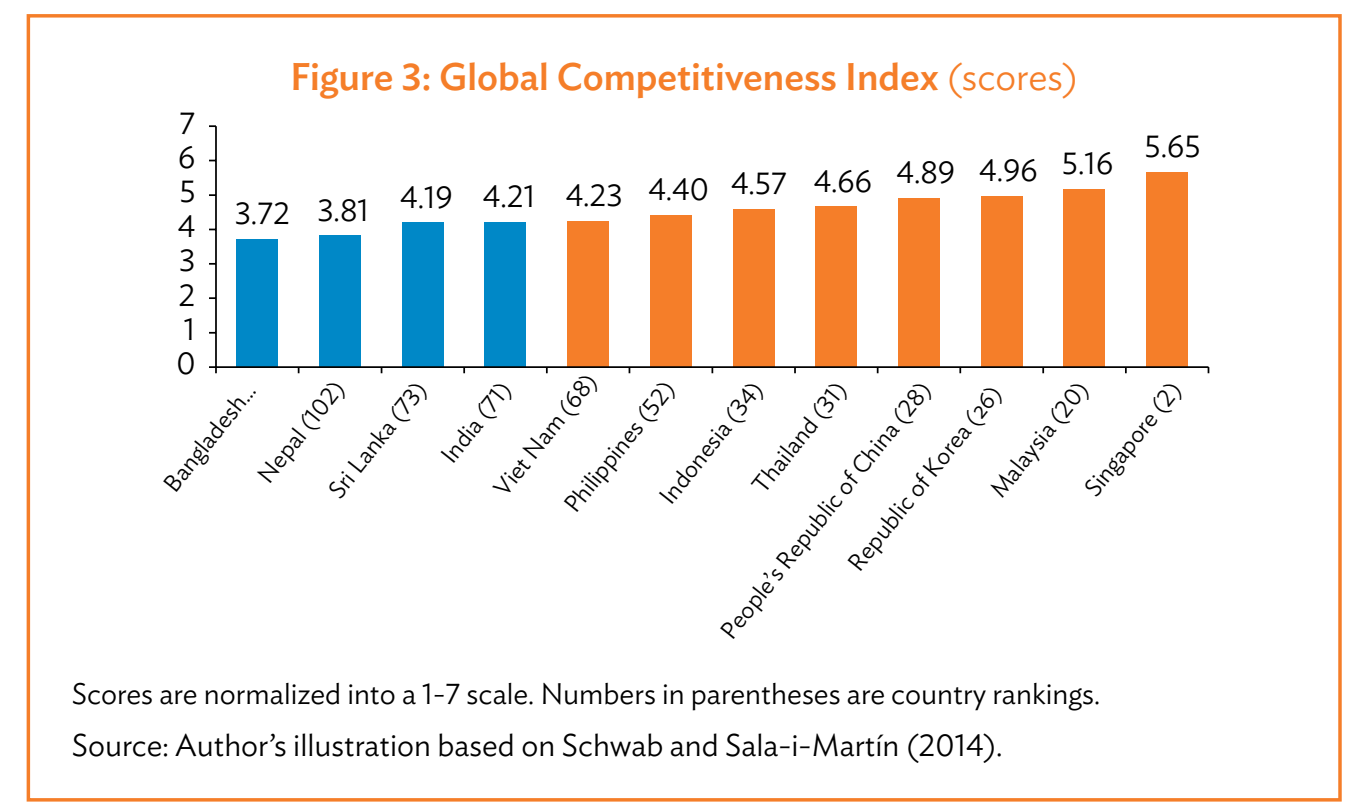

Bagwati and Paragariya (2013), while perceiving that the growth of human resources and demographic dividend in South Asia's largest economy-India-can place it on the same growth trajectory in the next decades as the PRC had in earlier years, pointed out that poor quality of education across levels can be a hindrance to long-term growth. Beyond having abundant low-cost labor, the ability of a country's workforce is central in allowing firms operating in the country to absorb and use technologies that may enhance industrial productivity, the quality of higher education and training is crucial for economies wanting to move up the value chain, and produce more sophisticated or value-intensive products 
Figure 4: Health, Education, and Technological Readiness

A. Health and primary education and technological readiness

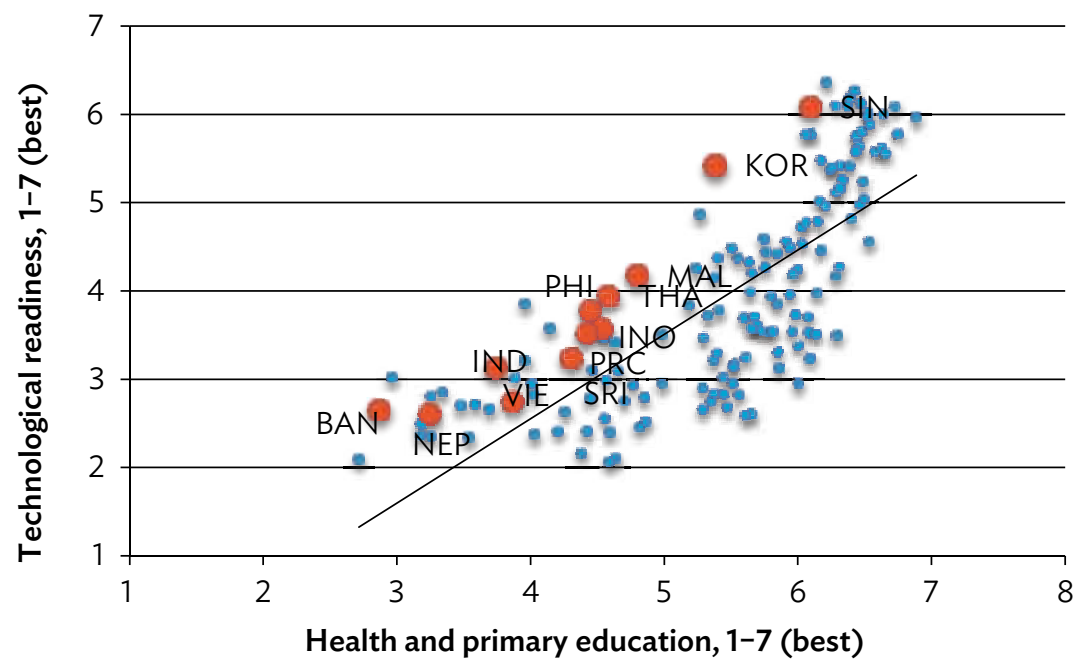

B. Higher education and technological readiness

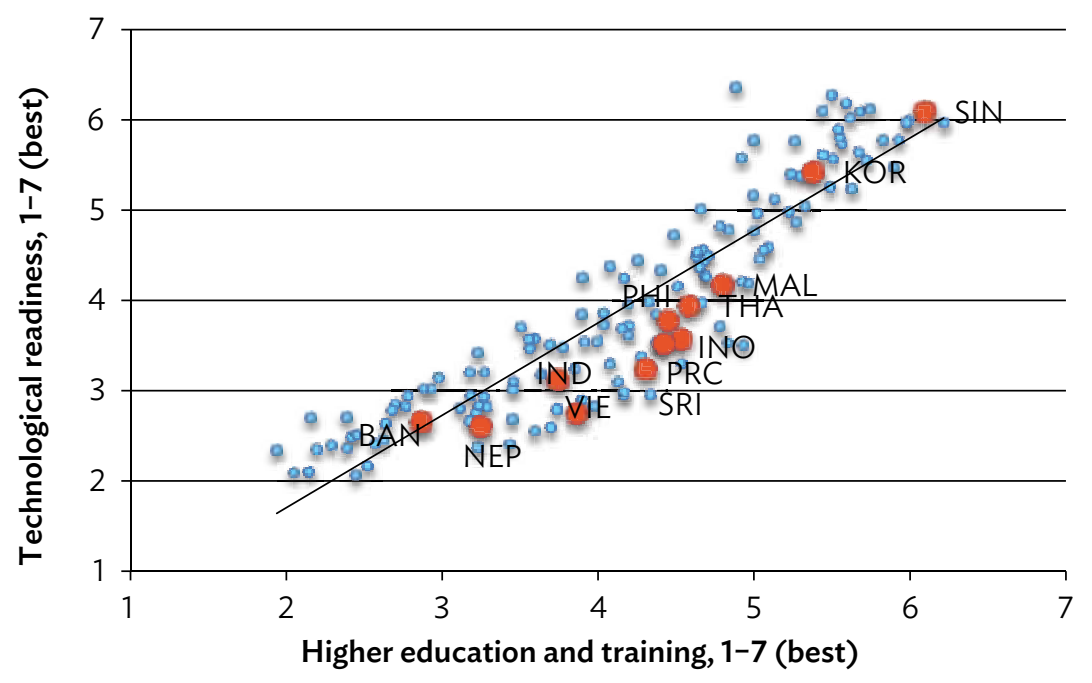

BAN = Bangladesh, IND = India, INO = Indonesia, $K O R=$ Republic of Korea, MAL = Malaysia, NEP = Nepal, $\mathrm{PHI}=$ Philippines, $\mathrm{PRC}=$ People's Republic of China, $\mathrm{SIN}=$ Singapore, $\mathrm{SRI}=$ Sri Lanka, $\mathrm{THA}=$ Thailand, $\mathrm{VIE}=$ Viet Nam .

Note: Scores are normalized into a 1-7 scale.

Source: Author's illustration based on Schwab and Sala-i-Martín. 2014. (accessed 30 October 2014). 
(Schwab and Sala-i-Martin 2014). Information and communication technologies (ICTs) and efficiency-enhancing production processes are key examples. In India, workers, especially young people, need opportunities to update and upgrade their skills continuously. Though India's public vocational education and training systems are well institutionalized, they lack the scale, curriculum, financing, and incentives needed to prepare young workers to meet the demands of rapid globalization and technological advancement (Lee 2014a).

Economies with well-educated workers are more agile in adopting existing technologies (Figure 4). A better-educated, well-trained, and healthier labor force that is adept at absorbing new technologies among other things (e.g., research and development [R\&D] investments, efficient goods market) is important especially for developing economies to catch up with the more progressive economies (Nelson and Phelps 1966, Borensztein et al. 1998, Barro and Sala-i-Martin 2004, and Drèze and Sen 2013).

\section{B. Role of Human Capital on Economic Development}

Growth theories explain that human capital development promotes economic growth over the long run (Lucas 1988 and 1993). This can be through raising the productivity and income of existing and future labor force (Box 7), attracting more physical capital, improving the local capacity to easily absorb and adapt existing technologies, and eventually, increasing the economy's capacity to innovate or develop new technologies, products, and processes (Bosworth and Collins 2003, Klenow and Rodriguez-Clare 1997, Mankiw et al. 1992, and Romer 1986 and 1990).

A large body of empirical work establishes the significant role of educational level and quality in driving economic growth (Hanushek and Woessman 2008a and 2008b, Temple and Woessmann 2006, Barro and Sala-i-Martin 2004, Krueger and Lindahl 2001, Mankiw et al. 1992, and Barro 1991). Studies have shown that student test scores on international assessments are positively related to economic growth (Hanushek and Woessman 2008). Hanushek and Woessman (2008a), for example, found that a 1 standard deviation increase in student test scores on international assessments of literacy and mathematics is associated with a $2 \%$ increase in annual GDP per capita growth.

Even small investments in human capital can have a major impact on poverty reduction. Education and its implications for a poor person's ability to find a job is a key element to making growth inclusive and sharing its proceeds widely. A study of 21 developing countries - including Bangladesh, Nepal, and Sri Lanka-by Inchauste and SaavedraChanduvi (forthcoming) indicates that growth in labor income (i.e., growth in employment and in earnings per worker) made a huge contribution in poverty reduction in these countries. In Bangladesh (2000-2010) and Nepal (1996-2003), labor income growth accounted for more than half of the reduction in poverty, and more than two-fifths in Sri Lanka (2002-2009).

As an economy's human capital grows, aside from generating more income from employment in the home country, migrant workers can also generate and send more 
income for the home country from working abroad. Although workers' migration can have negative consequences to the source economy (e.g., brain drain) and left-behind family (i.e., due to parental absence), many studies confirm an overall positive impact of overseas workers' remittances on home country's growth and development, especially in developing countries (Box 2).

\section{Box 2: Economic Impact of Workers' Remittances: Evidence from Developing Economies}

In 2013, \$414 billion or three-quarters of the world's remittance flows were sent to developing economies. Of this, over $27 \%$ were received by economies in East Asia and the Pacific, while over $23 \%$ were received by those in South Asia (i.e., Bangladesh, India, Nepal, and Sri Lanka). India was the largest recipient of remittances ( $\$ 70$ billion in 2013), followed by the People's Republic of China ( $\$ 59.5$ billion), and the Philippines ( $\$ 26.7$ billion). Bangladesh ranked ninth, with $\$ 13.9$ billion remittance receipts. The ratio of worker's remittances to gross domestic product (GDP) in South Asian countries can be as high as $28.8 \%$ of GDP (in Nepal) to as little as $3.7 \%$ (in India). In Bangladesh and Sri Lanka, remittance inflows are equivalent to around 10\% of GDPcomparable with that in the Philippines (9.8\%).

Source: World Bank. 2015a. World Development Indicators Online. http://databank.worldbank.org.

By reducing liquidity constraints, remittance income may improve domestic investment on physical capital, as well as on human capital of household members, and therefore positively affect economic growth (Pradhan et al. 2008, Jongwhanich 2007). Many studies on developing economies have confirmed that remittances generally raise health and educational investments for left-behind children, as well as school attendance or attainment among them (e.g., Adams and Cuecuecha 2010 for Indonesia, Vogel and Korinek 2012 for Nepal, Mansuri 2006 for Pakistan, and Quisumbing and McNiven 2010 and Yang 2008 for the Philippines). Ziesemer (2009) found that a 1 percentage point increase in remittance-to-GDP ratio is associated with a 0.7 percentage point increase in savings.

Although positive, growth accounting estimates suggest that the direct contribution of human capital, measured by the improvement of educational attainment for labor force, to GDP growth is smaller than either physical capital per worker or total factor productivity (TFP) growth. For instance, Collins (2007) showed that, of the $2.4 \%$ annual growth in output per worker in South Asian economies (including Bangladesh, India, Pakistan, and Sri Lanka) over the period 1960-2003, education accounted for only around 0.35 percentage points. Average growth in output per worker was around 2.6\% per year in India, 2.3\% in Sri Lanka, but only $1.2 \%$ in Bangladesh. Of these, education accounted for over 0.3 percentage points for both India and Sri Lanka, but only 0.2 percentage points for Bangladesh. Note, however, that the increase in educational attainment of about 0.3 percentage points per year can make sizable differences in the living standard over the long term. It could lead to about a $10 \%$ increase in per worker GDP or per capita income of about $10 \%$ after a generation, in addition to the possible impact of education on physical capital accumulation and TFP growth. 
Between 1961 and 2010, the average annual GDP growth rate was 3.4\% in Bangladesh, 5.1\% in India, and $5.0 \%$ in Sri Lanka. ${ }^{3}$ During the same period, the economies of the PRC (7.6\%), the Republic of Korea (7.1\%), Malaysia (6.4\%), Singapore (7.4\%), and Thailand (6.6\%) grew at a much faster rate. Bangladesh and India have demonstrated improvement in economic growth since the 1980 (Table 3). The average annual GDP growth rate increased from 1.4\% in 1961-1980 to 4.7\% in 1981-2010 in Bangladesh and from 3.6\% in 1961-1980 to 6.1\% in 1981-2010 in India. Unlike these two countries, Sri Lanka's average annual GDP growth rates were relatively stable, decreasing slightly from $5.2 \%$ in $1961-1980$ to $4.8 \%$ in 19812010.

As shown in Table 3, India's average educational attainment grew at about 0.3\% in 19611980 , contributing to about $10 \%$ of annual GDP growth in 1961-1980, while it grew at $0.9 \%$, contributing to $14 \%$ of annual GDP growth in 1981-2010. In Bangladesh, annual growth rate of average schooling years increased from $0.2 \%$ in $1961-1980$ to $0.5 \%$ in $1981-2010$, accounting for about $16 \%$ and $10 \%$ of annual GDP growth, respectively. Sri Lanka presents increase in the growth rate of average schooling years from $0.4 \%$ in $1961-1980$ to $0.5 \%$ in 1981-2010, contributing about 7\% and 11\% of annual GDP growth, respectively. The growth rate of human capital and its contribution to GDP growth in South Asian economies are quite comparable with, or slightly higher than, those in most of other Asian economies (Table 3).

In Sri Lanka, human capital contributed about $11 \%$ of the average GDP per worker growth rate in the first period and $16 \%$ in the second period. Its contribution was larger in both Bangladesh (i.e., $43 \%$ in the first period and $21 \%$ in the second period) and India (21\% in the first period and $22 \%$ in the second period).

Although the accumulation of physical capital explains a larger portion of GDP per worker growth in all Asian economies, human capital has nonetheless contributed more significantly to the growth in GDP per worker growth than in TFP in many countries. The gap in growth rates of GDP per worker between South Asian and other Asian economies is, for most cases, attributed to differences in growth rates in physical capital and TFP, rather than in human capital. For example, both the growth in physical capital and TFP each contributed to almost half of the average GDP per worker growth rate of around $8 \%$ in the PRC in 1981-2010. In the same period, growth in physical capital contributed about 41\% and TFP $37 \%$ of the average GDP per worker growth rate of less than $4 \%$ in India.

Note that growth accounting only accounts for the direct contribution of each of the factors of production, and disregards interaction effects between inputs, such as the contribution of human capital to the growth of physical capital and technological progress. As noted earlier, the level and quality of education and skills of the labor force, which broadly determine technological readiness of workers, play a very important role in the rates of technological progress and innovation in an economy. Given access to advanced technology, having a pool of well-educated and skilled workers is a crucial determinant

\footnotetext{
3 Based on available data for selected economies in South Asia (Bangladesh, India, and Sri Lanka) and selected Asian countries (the PRC, Indonesia, the Republic of Korea, Malaysia, the Philippines, Singapore, and Thailand) over the periods 1961-1980 and 1981-2010. Average human capital (i.e., aggregate labor quality) is measured as the weighted sum of the shares of workers multiplied by the relative marginal products (or relative wage rates) across all education categories.
} 
of the domestic absorptive capacity or the capability to absorb the spillovers of foreign technologies (Abramovitz 1986), and therefore the extent and speed of technological diffusion in the country. Having the appropriate pool of workers who can perform complex tasks, adopt existing technologies, and adapt rapidly to the evolving needs of the production system is especially important for economies in moving up the value chain and transitioning from simple, more advance production processes, toward more sophisticated, high-value products (Schwab and Sala-i-Martín 2013, ADB 2012a).

Table 3: Growth Accounting for Gross Domestic Product per Worker

\begin{tabular}{|c|c|c|c|c|c|}
\hline \multirow[b]{2}{*}{$\begin{array}{l}\text { Region, Country, } \\
\text { and Period }\end{array}$} & \multirow[b]{2}{*}{$\begin{array}{c}\text { Annual GDP } \\
\text { Growth Rate (\%) }\end{array}$} & \multirow[b]{2}{*}{$\begin{array}{l}\text { GDP per Worker } \\
\text { Growth Rate (\%) }\end{array}$} & \multicolumn{3}{|c|}{ Contribution of } \\
\hline & & & $\begin{array}{c}\text { Physical } \\
\text { Capital/Worker }\end{array}$ & $\begin{array}{l}\text { Human } \\
\text { Capital }\end{array}$ & $\begin{array}{l}\text { TFP } \\
\text { Growth }\end{array}$ \\
\hline \multicolumn{6}{|l|}{ South Asia } \\
\hline \multicolumn{6}{|l|}{ Bangladesh } \\
\hline \multirow[t]{2}{*}{ 1961-1980 } & 1.36 & -0.51 & -0.26 & 0.22 & -0.47 \\
\hline & & $(100.0)$ & $(-50.6)$ & $(43.2)$ & $(-92.6)$ \\
\hline \multirow[t]{2}{*}{ 1981-2010 } & 4.68 & 2.18 & 1.36 & 0.45 & 0.36 \\
\hline & & $(100.0)$ & $(62.6)$ & (20.7) & (16.8) \\
\hline \multicolumn{6}{|l|}{ India } \\
\hline \multirow[t]{2}{*}{ 1961-1980 } & 3.60 & 1.63 & 0.58 & 0.34 & 0.71 \\
\hline & & $(100.0)$ & $(35.4)$ & (21.1) & $(43.5)$ \\
\hline \multirow[t]{2}{*}{ 1981-2010 } & 6.10 & 3.87 & 1.59 & 0.86 & 1.42 \\
\hline & & $(100.0)$ & $(41.0)$ & $(22.3)$ & (36.7) \\
\hline \multicolumn{6}{|l|}{ Sri Lanka } \\
\hline \multirow[t]{2}{*}{ 1961-1980 } & 5.24 & 3.68 & 0.50 & 0.38 & 2.80 \\
\hline & & $(100.0)$ & $(13.7)$ & (10.4) & (75.9) \\
\hline \multirow[t]{2}{*}{ 1981-2010 } & 4.77 & 3.23 & 0.75 & 0.52 & 1.96 \\
\hline & & $(100.0)$ & $(23.3)$ & $(16.0)$ & $(60.7)$ \\
\hline \multicolumn{6}{|l|}{$\begin{array}{l}\text { Other Asian } \\
\text { countries }\end{array}$} \\
\hline \multicolumn{6}{|l|}{ PRC } \\
\hline \multirow[t]{2}{*}{ 1961-1980 } & 4.64 & 1.64 & 1.25 & 0.26 & 0.13 \\
\hline & & $(100.0)$ & $(76.2)$ & (15.9) & (7.9) \\
\hline \multirow[t]{2}{*}{ 1981-2010 } & 9.58 & 7.95 & 3.88 & 0.19 & 3.88 \\
\hline & & $(100.0)$ & $(48.7)$ & $(2.4)$ & $(48.8)$ \\
\hline \multicolumn{6}{|l|}{ Indonesia } \\
\hline \multirow[t]{2}{*}{ 1961-1980 } & 5.25 & 2.94 & 0.74 & 0.23 & 1.98 \\
\hline & & $(100.0)$ & $(25.0)$ & (7.7) & (67.3) \\
\hline \multirow[t]{2}{*}{$1981-2010$} & 5.11 & 2.72 & 2.50 & 0.37 & -0.15 \\
\hline & & $(100.0)$ & (91.9) & $(13.5)$ & $(-5.4)$ \\
\hline
\end{tabular}


Table 3 continued

\begin{tabular}{|c|c|c|c|c|c|}
\hline \multirow[b]{2}{*}{$\begin{array}{l}\text { Region, Country, } \\
\text { and Period }\end{array}$} & \multirow[b]{2}{*}{$\begin{array}{c}\text { Annual GDP } \\
\text { Growth Rate (\%) }\end{array}$} & \multirow[b]{2}{*}{$\begin{array}{l}\text { GDP per Worker } \\
\text { Growth Rate (\%) }\end{array}$} & \multicolumn{3}{|c|}{ Contribution of } \\
\hline & & & $\begin{array}{c}\text { Physical } \\
\text { Capital/Worker }\end{array}$ & $\begin{array}{l}\text { Human } \\
\text { Capital }\end{array}$ & $\begin{array}{c}\text { TFP } \\
\text { Growth }\end{array}$ \\
\hline \multicolumn{6}{|l|}{ Korea, Rep. of } \\
\hline \multirow[t]{2}{*}{ 1961-1980 } & 8.02 & 4.50 & 2.13 & 0.43 & 1.95 \\
\hline & & $(100.0)$ & $(47.2)$ & $(9.4)$ & $(43.3)$ \\
\hline \multirow[t]{2}{*}{ 1981-2010 } & 6.56 & 4.68 & 2.84 & 0.39 & 1.45 \\
\hline & & $(100.0)$ & $(60.7)$ & (8.3) & (31.0) \\
\hline \multicolumn{6}{|l|}{ Malaysia } \\
\hline \multirow[t]{2}{*}{ 1961-1980 } & 7.49 & 4.33 & 1.46 & 0.43 & 2.44 \\
\hline & & $(100.0)$ & (33.7) & $(9.9)$ & (56.4) \\
\hline \multirow[t]{2}{*}{ 1981-2010 } & 5.69 & 2.65 & 1.92 & 0.45 & 0.28 \\
\hline & & $(100.0)$ & (72.4) & $(17.0)$ & (10.6) \\
\hline \multicolumn{6}{|l|}{ Philippines } \\
\hline \multirow[t]{2}{*}{ 1961-1980 } & 5.28 & 2.09 & 1.35 & 0.20 & 0.54 \\
\hline & & $(100.0)$ & $(64.5)$ & $(9.7)$ & (25.7) \\
\hline \multirow[t]{2}{*}{ 1981-2010 } & 3.05 & 0.40 & 0.97 & 0.13 & -0.71 \\
\hline & & $(100.0)$ & $(244.6)$ & (33.0) & $(-177.6)$ \\
\hline \multicolumn{6}{|l|}{ Singapore } \\
\hline \multirow[t]{2}{*}{ 1961-1980 } & 8.69 & 4.89 & 2.79 & 0.13 & 1.96 \\
\hline & & $(100.0)$ & $(57.2)$ & $(2.8)$ & (40.1) \\
\hline \multirow[t]{2}{*}{ 1981-2010 } & 6.61 & 3.18 & 2.12 & 0.44 & 0.61 \\
\hline & & $(100.0)$ & $(66.9)$ & $(13.9)$ & (19.2) \\
\hline \multicolumn{6}{|l|}{ Thailand } \\
\hline \multirow[t]{2}{*}{ 1961-1980 } & 8.39 & 6.07 & 3.39 & -0.03 & 2.71 \\
\hline & & $(100.0)$ & (55.9) & $(-0.6)$ & (44.7) \\
\hline \multirow[t]{2}{*}{ 1981-2010 } & 5.48 & 3.63 & 2.19 & 0.35 & 1.09 \\
\hline & & $(100.0)$ & $(60.3)$ & $(9.7)$ & $(30.0)$ \\
\hline
\end{tabular}

GDP = gross domestic product, $\mathrm{PRC}=$ People's Republic of China, TFP = total factor productivity.

Note: Figures in parentheses are the contributions of each of the factors of production to annual GDP per worker growth rate.

Source: Author's estimates.

A growing body of empirical literature establishes the positive impact of human capital on productivity, technology adaptation, and innovation. For instance, Lee (2001) found that, in developing countries, the stock of human capital with higher levels of education strongly determines the development of ICT. In Sri Lanka, Dutz and O'Connell (2013) found that availability of skills has a strong positive relationship with productivity and innovation (i.e., introduction of new products or processes), both within and across firms. They found that, within a cluster of firms, output per worker is three times higher if all firms train workers than otherwise. 
Aside from having better infrastructure and more flexible human resource policies than India, the higher technical factor productivity in the PRC can be explained by having more skilled workers ( $\mathrm{Li}$ et al. 2011). For instance, while over $22 \%$ of workers in firms in the PRC use computers regularly on the job, only less than $17 \%$ of workers do in India. In the PRC, every additional year of schooling among workers is associated with a $30 \%$ increase in worker's marginal product (Fleisher et al. 2011).

According to Fleisher et al. (2010), the PRC's regional growth patterns are related to regional differences in physical and human capital, among other things. They found that human capital positively affects output and productivity growth across provinces through direct (e.g., domestic innovation activities) and indirect (e.g., spillover effect on TFP growth) processes. They also found that, while investment in infrastructure generates higher returns in developed regions, human capital investment generates slightly higher or comparable returns in less-developed areas.

Improvements in human capital played a key role in the structural transformation of the economies of the PRC and India, and in achieving high growth rates in the past decades. Using firm-level data, Hsieh and Klenow (2009), for instance, found that, on the one hand, inefficiencies due to misallocation of factors of production may have shaved $2 \%$ off Indian manufacturing TFP growth from 1987 to 1994 . On the other hand, because of allocative efficiency improvements, the PRC may have boosted its TFP by $2 \%$ per year during $1998-$ 2005.

Micro data analysis by Lee and Malin (2013) has revealed that education plays an important role in improving the allocation of labor between the PRC's agriculture and nonagriculture sectors. They estimated that, during 1978-2004, around 11\% of aggregate growth in output per worker was due to increased education. Of this, 9 percentage points were gained through the labor reallocation channel, and the remaining 2 percentage points was due to higher within-sector human capital.

Human capital stock interacts with inflows of foreign technology-embodied foreign direct investment (FDI), and thereby contributes to technology growth in developing countries (Borensztein et al. 1998). FDI by multinational corporations, which often carry out a substantial part of the world's R\&D investment, is considered as a highly important channel of technology diffusion (Findlay 1978, Lee and Shin 2012). Empirical studies have shown that FDI contributes significantly to productivity growth when the host economy satisfies a minimum threshold stock of educated workers (Borensztein et al. 1998, Xu 2000).

Nevertheless, technological adoption alone does not guarantee sustained productivity growth in an economy. An economy's catch-up speed to the world technology frontier is inversely related to the gap between the domestic and global levels of sophistication. This is also known as the "advantage of backwardness" (Gerschenkron 1962). This implies that, as the gap closes, it gets more and more difficult for the lagging economy to catch up with the more advanced ones. To sustain productivity growth, in addition to adaptation of existing technologies, the emerging economy needs to eventually innovate and produce its own technologies. As this occurs, accumulating higher levels of human capital becomes more important. 
Human capital and R\&D investment have significant and positive effects on TFP growth. Estimates by Park (2012) based on a panel of cross-country data over the period 19702007 indicate that a 1-year increase in average years of schooling leads to an increase in TFP growth by about 0.3 percentage points per year (Table 4). Overall, empirical results confirm that human capital is a key factor in developing countries. Its expansion should be important for sustained economic growth of South Asian countries. To promote technological progress, they must improve its quantity and quality of education, while expanding investments for technology imports and innovation.

The role of human capital in technological advancement was highly evident in the case of the PRC and other advanced East Asian economies, where they capitalized on their healthy and highly capable workforce to adaptation-existing technologies. In contrast, employer surveys in South Asia increasingly suggest that poor learning outcomes and a shortage of skills are barriers to private sector investment and growth (World Bank 2011a). For instance, employers in India or even in Sri Lanka-South Asia's outlier in education-see an inadequately educated labor force as a severe constraint (Mckinsey Global Institute 2012b, World Bank 2011a).

Confirming this, Lee and Shin (2012) found that technology gap, the initial stock of human capital (measured by average years of secondary and tertiary schooling), and FDI have positive impacts on the growth rate of TFP. For every additional year of secondary and tertiary schooling, annual TFP growth is promoted by 0.8 percentage points. Take for instance, the average number of years of secondary and tertiary schooling over the period 1970-2000 for the following countries: India, 1.1; Bangladesh, 0.8; Nepal, 0.7; Sri Lanka, 2.2; and the Republic of Korea, 3.4 years. The Republic of Korea's schooling advantage over these South Asian countries is estimated to have raised its TFP growth by an average of between 1.0 and 2.2 percentage points per year.

Table 4: Research and Development Model of Total Factor Productivity Growth (Dependent variable: Average growth rate of total factor productivity)

\begin{tabular}{|l|c|c|c|c|}
\hline Explanatory Variables & $(1)$ & $(2)$ & $(3)$ & $(4)$ \\
\hline Log GDP gap with the US & $\begin{array}{c}-0.012^{* * *} \\
(-7.479)\end{array}$ & $\begin{array}{c}-0.011^{* * *} \\
(-6.869)\end{array}$ & $\begin{array}{c}-0.009^{* * *} \\
(-3.962)\end{array}$ & $\begin{array}{c}-0.008^{* * *} \\
(-3.565)\end{array}$ \\
\hline Life expectancy gap with the US & $\begin{array}{c}0.052^{* * *} \\
(4.674)\end{array}$ & $\begin{array}{c}0.045^{* * *} \\
(4.033)\end{array}$ & $\begin{array}{c}0.030^{*} \\
(1.858)\end{array}$ & $\begin{array}{c}0.029^{*} \\
(1.835)\end{array}$ \\
\hline Human capital & $\begin{array}{c}0.022^{* * *} \\
(4.594)\end{array}$ & $\begin{array}{c}0.023^{* * *} \\
(4.796)\end{array}$ & $\begin{array}{c}0.016^{* * *} \\
(3.471)\end{array}$ & $\begin{array}{c}0.019^{* * *} \\
(3.952)\end{array}$ \\
\hline Asian economy dummy & & $\begin{array}{c}0.011^{* * *} \\
(2.869)\end{array}$ & & $\begin{array}{c}0.010^{* * *} \\
(2.862)\end{array}$ \\
\hline R\&D capital stock per worker, & & & $0.063^{* * *}$ & $0.057^{* *}$ \\
growth rate & & & $(2.534)$ & $(2.313)$ \\
\hline Number of Observations & 505 & 505 & 146 & 146 \\
\hline Adjusted R-squared & 0.167 & 0.179 & 0.204 & 0.243 \\
\hline
\end{tabular}

GDP = gross domestic product, R\&D = research and development, US = United States.

Notes:

${ }^{* * *}, * * *$ indicate significance at the $10 \%, 5 \%$, and $1 \%$ levels, respectively. $t$-statistics are in parentheses. All models include period dummies, but are not reported here.

${ }^{a}$ Human capital $=\exp (0.08 \times h)$, where $h$ is the 10 -year average educational attainment level.

Source: Park (2012). 
They also confirm the complementarity between human capital and FDI. By promoting the inflow of advanced technologies through FDI and, more importantly, complementing it, human capital can help in substantially narrowing the gap in TFP growth rates. In the last decade, FDI flows to South Asia increased significantly as its business environment improved, thereby narrowing the gap with the PRC, and contributing to faster growth. The ratio of FDI to GDP in 2005-2010 was 0.022 in India, 0.010 in Bangladesh, and 0.015 in Sri Lanka, while negligible in Nepal. This highlights that South Asian countries have achieved significant productivity growth by promoting both greater access to advanced technologies, as well as the accumulation of skilled human resources that are capable of developing or using new technologies.

\section{Skills Development and Economic Growth}

As a country's production shift from low-skill industries that are less skill-intensive toward greater production in high-skill industries, more highly skilled workers are needed (Heckman et al. 2006). Arguably, an individual's productivity is largely determined by one's cognitive skills such as numeracy, literacy, problem-solving ability, and general scientific understanding of the world.

Measuring the level of skills of the labor force is a challenging task. Although estimates of average years of schooling can provide a reasonable proxy for the stock of educational capital for a broad group of countries, they do not take into account the differences in the quality of schooling across countries and over time. Recent literature compares educational quality using internationally comparable test scores at the primary and secondary levels, such as the Third International Mathematics and Science Study and the Programme for International Student Assessment (PISA). ${ }^{4}$

Studies have found that the test score measures are more significantly linked to economic growth than average years of schooling in cross-country regressions (Hanushek and Kimko 2000, and Hanushek and Woessman 2012). Studies have also observed a significant role of test scores on economic growth in cross-country regressions (Barro and Lee 2015).

Although students' test scores, which reflect the quality of schooling, can be a good indicator of the quality of additional labor force, these scores do not directly measure the stock of educational capital held by a country's working-age population. Both test scores and educational attainment do not reflect the skills and experience acquired by individuals, or the knowledge they lose, after they graduate from school. Hence, current cognitive test scores of adults, rather than students, may be a better measure of a labor force's current cognitive ability.

There have been attempts to directly measure the skills of the labor force across countries. For instance, three adult literacy surveys have been undertaken over a number of countries: the International Adult Literacy Survey (IALS), the Adult Literacy and Life Skills Survey, and the Programme for the International Assessment of Adult Competencies (PIAAC). Conducted in 1994 for the first time, the IALS provides a direct comparison of certain

$\overline{4}$ See Barro and Lee (2015) for literature survey and a newly constructed cross-country data. 
work-related skills in adult populations across 23 countries, which are mostly Organisation for Economic Co-operation and Development (OECD) member countries. Three domains were considered to measure literacy, including literacy on prose, document, and numbers. Patterned after the IALS, the ALLS also considered problem-solving on top of the three domains of IALS. Adult Literacy and Life Skills Surveys were conducted between 2003 and 2008 over a nationally representative sample of 16-65-year olds in only 10 countries.

OECD (2013b) developed PIAAC, which has involved 33 countries in two rounds since 2008. PIAAC assessed the proficiency of adults from ages 16-65 in literacy, numeracy, and problem-solving in technology-rich environments (problem-solving). PIAAC measures each of the three skill domains on a 500-point scale. The results are available from 24 countries that surveyed around 166,000 adults aged 16-65.

As shown in Table 5, Japan had the highest average test scores in all three skill domainsnumeracy (288), literacy (296), and problem-solving (294) - among the countries that participated in the PIAAC. ${ }^{5}$ Finland ranked second and the Netherlands third in numeracy and literacy. Australia ranked second and Finland third in problem-solving. The Republic of Korea ranked 16th in numeracy (263 points), 13th in literacy (273 points), and 11th in problem-solving (283 points).

Based on an analysis of PIAAC data on 22 countries, Hanushek et al. (2013) found that cognitive skills have a strong positive impact on individual earnings. Our analysis, using PIAAC data for the Republic of Korea (the only country that participated in the PIAAC among our selected South Asian and Southeast Asian countries), has confirmed the significant role of both schooling and on-the-job training on labor productivity or wages (Box 3). On top of formal schooling, on-the-job training improves skills of workers entering the labor markets. Work experience has also a significantly positive effect on all skill domains. The point estimates indicate that 1-year experience has the effect on skills by about $5 \%-10 \%$ of the skill impact of 1 year's formal schooling.

Empirical studies based on firm and industry data also support the importance of skill upgrading of workers and lifelong learning. A 1995 World Bank report found that enterprise training in a number of developing economies that include Colombia; Indonesia; Malaysia; Mexico; and Taipei,China is associated with higher firm-level productivity in all five economies (Tan and Batra 1995). A recent study by Konings and Vanormelingen (2015) found that, even after controlling for endogeneity of training, the marginal product of a trained worker was, on average, $23 \%$ higher than that of an untrained worker across firms in Belgium.

\footnotetext{
5 OECD (2013). Literacy is defined as "the ability to understand, evaluate, use, and engage with written texts to participate in society, to achieve one's goals, and to develop one's knowledge and potential." Numeracy is defined as "the ability to access, use, interpret, and communicate mathematical information and ideas in order to engage in and manage the mathematical demands of a range of situations in adult life". Problem-solving in technology-rich environments is defined as "the ability to use digital technology, communication tools, and networks to acquire and evaluate information, communicate with others, and perform practical tasks." (Humburg and van der Velden 2015).
} 
Table 5. Program for the International Assessment of Adult Competencies Average Test Scores

\begin{tabular}{|c|c|c|c|c|c|}
\hline \multicolumn{2}{|l|}{ Numeracy } & \multicolumn{2}{|l|}{ Literacy } & \multicolumn{2}{|c|}{ Problem-Solving } \\
\hline Country & Score & Country & Score & Country & Score \\
\hline Japan & 288 & Japan & 296 & Japan & 294 \\
\hline Finland & 282 & Finland & 288 & Australia & 289 \\
\hline Netherlands & 280 & Netherlands & 284 & Finland & 289 \\
\hline Belgium (Flanders) & 280 & Australia & 280 & Sweden & 288 \\
\hline Sweden & 279 & Sweden & 279 & Netherlands & 286 \\
\hline Denmark & 278 & Norway & 278 & Norway & 286 \\
\hline Norway & 278 & Estonia & 276 & Austria & 284 \\
\hline Czech Republic & 276 & Belgium (Flanders) & 275 & Czech Republic & 283 \\
\hline Slovak Republic & 276 & Russian Federation & 275 & Denmark & 283 \\
\hline Austria & 275 & Czech Republic & 274 & Germany & 283 \\
\hline Estonia & 273 & Slovak Republic & 274 & Korea, Republic of & 283 \\
\hline Germany & 272 & Canada & 273 & Canada & 282 \\
\hline Russian Federation & 270 & Korea, Republic of & 273 & Slovak Republic & 281 \\
\hline Australia & 268 & United Kingdom & 272 & Belgium (Flanders) & 281 \\
\hline Canada & 265 & Denmark & 271 & United Kingdom & 280 \\
\hline Korea, Republic of & 263 & Germany & 270 & Estonia & 278 \\
\hline United Kingdom & 262 & United States & 270 & Ireland & 277 \\
\hline Poland & 260 & Austria & 269 & United States & 277 \\
\hline Ireland & 256 & Ireland & 267 & Russian Federation & 276 \\
\hline France & 254 & Poland & 267 & Poland & 275 \\
\hline United States & 253 & France & 262 & Cyprus & 267 \\
\hline Cyprus & 250 & Spain & 252 & & \\
\hline Italy & 247 & Italy & 250 & & \\
\hline Spain & 246 & Cyprus & 250 & & \\
\hline
\end{tabular}

Source: Organisation for Economic Co-operation and Development (2013). 


\section{Box 3: Determinants of Skills in the Republic of Korea}

In addition to questions related to their skills, respondents of the Programme for the International Assessment of Adult Competencies (PIAAC) survey were asked to provide some basic personal and employment information such as age, sex, education, immigration, language, education of parents, wage, and job. The mean age of the respondents in the Republic of Korea, who were full-time employees aged 25-65, was 43 years old and the share of female was 39\%. Respondents took over 13 years of schooling and almost 16 years of experience of actual paid work on average. First-generation and nonnative immigrants are $1 \%$ in total sample. About $0.4 \%$ of the respondents spoke other languages than Korean at home. The highest level of schooling between mother and father was 10.8 years. On average, the respondents took 0.29 weeks of job-related and 0.34 weeks of non-job-related nonformal education over the 12 months prior to the survey.

The following skill production function is estimated using the sample of Koreans aged 25-65 participants in the PIAAC:

$$
\text { score }_{i}=\alpha+1 \beta+F \gamma+J \delta+\varepsilon_{i}
$$

where score $_{i}$ is a test score of each assessment domain of individual $i$; I are individual characteristics such as age, female indicator, years of schooling, immigration background, and language spoken at home; $F$ are family characteristics such as highest level of parents' years of schooling and number of books at home; J are job characteristics such as number of weeks spent in job-related or non-job-related education and experiences.

Box Table 1 reports the estimates of individual, family, and job characteristic variables for test score of each skill domain. Age has a negative effect on skill test scores. When other variables are controlled, females have lower scores than males. The gender differentials range from 2.6 points in literacy to 7.1 points in problem-solving. An increase in average schooling by 1 year raises average test scores in problem-solving by 3.7 points, literacy by 4.8 points, and numeracy by 6.0 points. Nonnative individuals who do not use Korean at home have very low test scores compared with native Koreans. Parents' schooling has a positive effect on all skill domains. The estimates range from 0.57 in numeracy to 0.85 in problem-solving, equivalent to $10 \%-23 \%$ of the point estimates on individuals' own schooling. The more books there are at home, the higher the test scores on skill domains.

On-the-job training affects positively and significantly the skills of workers in all three domains. An individual's test score increases by about 0.6 points in numeracy, 0.8 points in literacy, and 0.5 points in problem-solving, by attending job-related nonformal education for a week. The point estimates indicate that about a week of on-the-job training has the effect on skills as much as about $8 \%-15 \%$ of the skill impact of 1 year's formal schooling. Hence, on-the-job training can improve skills of the workers who entered labor markets after finishing formal schooling. The experience also has a significantly positive effect on all skill domains. The point estimates indicate that 1-year experience has the effect on skills by about $5 \%-10 \%$ of the skill impact of 1 year's formal schooling.

To estimate the effect of skill on wage, the following Mincer-type equation is estimated for the sample of Korean full-time employees aged 35-54a:

$$
\ln (\text { wage })_{i}=\alpha+\beta_{1} E d u_{i}+\beta_{2} \text { Skill }+\beta_{3} E_{i}+\beta_{4} E^{2}+\beta_{5} F_{i}+X \gamma+\varepsilon_{i}
$$

where In is a the log of hourly earnings including bonuses for wage and salary earners of individual $i, E d u_{i}$ is years of schooling, Skill ${ }_{i}$ is numeracy, literacy, or problem-solving test score, $\varepsilon_{i}$ is years of labor market experience, $F_{i}$ is female indicator, and $X$ are occupation-by-industry dummy variables. Occupation-by-industry fixed effects are used to control the differences in industry or occupation characteristics. Full-time employees are those working at least 30 hours per week. The top and bottom $1 \%$ to eliminate outliers were excluded. 
Standard deviations of test scores were rescaled to 1 to compare the effect on log of wage with that of years of schooling.

\section{Box Table 1: Skill Production Function Estimates}

\begin{tabular}{|c|c|c|c|}
\hline Dependent Variables & $\begin{array}{c}\text { (1) } \\
\text { Numeracy }\end{array}$ & $\begin{array}{c}(2) \\
\text { Literacy }\end{array}$ & $\begin{array}{l}\text { (3) } \\
\text { Problem-Solving }\end{array}$ \\
\hline \multicolumn{4}{|l|}{ Individual characteristics } \\
\hline \multirow[t]{2}{*}{ Age (years) } & $-0.821^{* * *}$ & $-0.866^{* * *}$ & $-1.501^{* * *}$ \\
\hline & $(0.041)$ & $(0.043)$ & $(0.078)$ \\
\hline \multirow[t]{2}{*}{ Female } & $-5.307^{* * *}$ & $-2.562^{* * *}$ & $-7.11^{* * *}$ \\
\hline & $(0.574)$ & $(0.605)$ & $(0.974)$ \\
\hline \multirow[t]{2}{*}{ Years of schooling } & $5.977^{* * *}$ & $4.791^{* * *}$ & $3.708^{* * *}$ \\
\hline & $(0.177)$ & $(0.155)$ & $(0.237)$ \\
\hline \multicolumn{4}{|l|}{ Immigration background } \\
\hline First-generation & -0.193 & -3.44 & $-8.89^{* *}$ \\
\hline (parents only born in other country) & $(2.707)$ & $(2.596)$ & $(3.898)$ \\
\hline Nonnative & $-27.985^{* * *}$ & $-32.669^{* * *}$ & $-32.347^{* * *}$ \\
\hline $\begin{array}{l}\text { (parents and siblings born in other } \\
\text { country) }\end{array}$ & $(2.974)$ & $(3.791)$ & $(3.973)$ \\
\hline \multicolumn{4}{|l|}{ Language spoken at home } \\
\hline \multirow[t]{2}{*}{ Not use the language of test } & $-27.324^{* * *}$ & $-31.143^{* * *}$ & $-48.287^{* * *}$ \\
\hline & $(4.95)$ & $(9.213)$ & $(14.402)$ \\
\hline \multicolumn{4}{|l|}{ Family characteristics } \\
\hline \multirow[t]{2}{*}{$\begin{array}{l}\text { Highest level of parents' years of } \\
\text { schooling }\end{array}$} & $0.569^{* * *}$ & $0.685^{* * *}$ & $0.852^{* * *}$ \\
\hline & $(0.14)$ & $(0.163)$ & $(0.239)$ \\
\hline \multicolumn{4}{|l|}{ Books at home $(0-10$ books $=0)$} \\
\hline \multirow[t]{2}{*}{$11-25$ books } & $4.511^{* * *}$ & $4.265^{* * *}$ & -0.639 \\
\hline & $(1.602)$ & $(1.057)$ & $(1.753)$ \\
\hline \multirow[t]{2}{*}{$26-100$ books } & $7.319^{* * *}$ & $7.596^{* * *}$ & $3.932^{* * *}$ \\
\hline & $(1.149)$ & $(0.648)$ & $(1.329)$ \\
\hline \multirow[t]{2}{*}{$101-200$ books } & $14.909^{* * *}$ & $10.722^{* * *}$ & $10.186^{* * *}$ \\
\hline & $(1.562)$ & $(0.948)$ & $(1.947)$ \\
\hline \multirow[t]{2}{*}{ More than 200 books } & $19.191^{* * *}$ & $18.386^{* * *}$ & $11.178^{* * *}$ \\
\hline & $(1.225)$ & $(1.366)$ & $(1.935)$ \\
\hline \multicolumn{4}{|l|}{ Job characteristics } \\
\hline \multirow[t]{2}{*}{ Job-related nonformal education } & $0.611^{* *}$ & $0.789^{* * *}$ & $0.516^{* *}$ \\
\hline & $(0.264)$ & $(0.228)$ & $(0.248)$ \\
\hline \multirow[t]{2}{*}{ Non-job-related nonformal education } & $0.696^{*}$ & $1.137^{* * *}$ & $0.723^{* *}$ \\
\hline & $(0.385)$ & $(0.251)$ & $(0.359)$ \\
\hline \multirow[t]{2}{*}{ Experience (years) } & $0.302^{* * *}$ & $0.244^{* * *}$ & $0.307^{* * *}$ \\
\hline & $(0.036)$ & $(0.033)$ & $(0.045)$ \\
\hline $\mathrm{N}$ & 4,440 & 4,440 & 4,440 \\
\hline $\mathrm{R}^{2}$ & 0.387 & 0.371 & 0.278 \\
\hline
\end{tabular}

Notes: Least squares regressions weighted by sampling weights are used. Sample consists of Korean PIAAC participants aged 25-65. Experience squared is divided by 100 . Robust standard errors are in parentheses. ${ }^{*} p<.1,{ }^{* *} p<.05,{ }^{* * *} p<.01$ 
Box 3 continued

The coefficients of the experience variable and its square suggest inverted $U$-shape relationship between experience and wage (Box Table 2). Female indicator suggests female employees earn on average about 32\%-34\% less than males, with schooling, skills, and experience controlled. The return to formal schooling is $4.5 \%$ per year in column (1). The point estimates in columns (2)-(4) indicate that the return to numeracy is $4.9 \%$, literacy $4.6 \%$, and problem-solving $2.8 \%$. Thus, the estimated impact of one-standard deviation increases in numeracy is $43.2 \%$ and literacy score (39.1), are almost equivalent to that of 1-year increase in average formal schooling, while one standard deviation increase in problem-solving i.e., (36.1), has about $60 \%$ of that of 1 -year increase in schooling.

\section{Box Table 2: Estimation of Wage Equations}

\begin{tabular}{|l|c|c|c|c|}
\hline Variables & $(1)$ & $(2)$ & $(3)$ & $(4)$ \\
\hline Years of schooling & $0.045^{* * *}$ & $0.04^{* * *}$ & $0.04^{* * *}$ & $0.046^{* * *}$ \\
\hline Numeracy & $(0.001)$ & $(0.001)$ & $(0.001)$ & $(0.001)$ \\
\hline & & $0.049^{* * *}$ & & \\
\hline Literacy & & $(0.01)$ & & \\
\hline & & & $0.046^{* * *}$ & \\
\hline Problem-solving & & & $(0.008)$ & \\
\hline & & & & $0.028^{* * *}$ \\
\hline Experience & & $0.027^{* * *}$ & $0.027^{* * *}$ & $0.032^{* * *}$ \\
\hline & $0.028^{* * *}$ & $(0.001)$ & $(0.001)$ & $(0.001)$ \\
\hline Experience squared & $(0.0005)$ & $-0.039^{* * *}$ & $-0.038^{* * *}$ & $-0.044^{* * *}$ \\
\hline Female & $-0.042^{* * *}$ & $-0.002)$ & $(0.002)$ & $(0.003)$ \\
\hline & $(0.001)$ & $(0.002)$ & $-0.324^{* * *}$ \\
\hline & $-0.339^{* * *}$ & $-0.335^{* * *}$ & $-0.336^{* * *}$ & $(0.005)$ \\
\hline Industry $x$ occupation dummy & $(0.003)$ & $(0.004)$ & $(0.004)$ & Yes \\
\hline N & & Yes & Yes & 1,417 \\
\hline R-squared & 1,417 & 1,417 & 1,417 & 0.570 \\
\hline
\end{tabular}

Notes: Least squares regressions weighted by sampling weights are used. Dependent variable is log of hourly earnings, including bonuses for wage and salary earners. Sample consists of full-time employees aged 35-54 working at least 30 hours per week in the Republic of Korea. Full-time employees are defined as those. Experience squared is divided by 100 . Test scores are standardized to std. dev. equal to 1. Robust standard errors are in parentheses. ${ }^{*} p<.1,{ }^{* *} p<.05,{ }^{* * *} p<.01$.

a See Lee and Wie (2015c) for details. The sample is limited to survey respondents who are full-time employees aged 35-54 to get best estimates of long-run returns to skills. See the discussion in Hanushek et al. (2015).

Source: J. W. Lee and D. Wie. 2015c. Returns to Education and Skill in the Labor Markets of Japan and Korea. In progress. 


\section{ACHIEVEMENTS AND CHALLENGES IN EDUCATION}

\section{Highlights}

- Although uneven across countries, South Asia has made strong educational progress in terms of school enrollment, especially at the primary and secondary levels, as well as overall attainment.

- However, significant school disparities remain in access, participation, and completion across gender, income, and social groups.

- The low quality of education and high disparity in learning outcomes are major challenges in South Asia.

- Higher public and private investments in education are necessary to upgrade and reduce disparities in learning outcomes.

The recognition of education as a fundamental driver of development has driven many countries worldwide to invest heavily on education and pursue the Millennium Development Goal (MDG) of achieving universal primary education, and eradicating gender disparities at all levels of education by 2015 since the beginning of the century (Lee 2014b). Although this has contributed considerably to expanding educational opportunities and attainment, and making them more gender-inclusive, there is much more to be done.

Although progress is uneven across South Asian countries, the number of primary schoolage children not attending school has gone down to less than $12 \%$ in the early first decade of the 21 st century level ${ }^{6}$ (World Bank 2015a 2015b). This was mainly driven by the progress in India. Nonetheless, around 21 million children aged 8-14 years ${ }^{7}$ in the region remain out of school, most of them are poor and girls (United Nations Educational, Scientific and Cultural Organization Institute for Statistics [UIS] 2015). While many of them were able to start school but left early, some were never able to attend school. Educational disparities across regions, gender, and social strata are especially obscure at the higher educational levels.

Above all, the overall quality of education in most countries in South Asia, which is related to both the low quality of education and inadequate early childhood nutrition and development, is alarmingly below par. Thus, even those who are attending school are not getting the necessary cognitive skills to be productive.

\footnotetext{
6 Including all six countries: Bangladesh, Bhutan, India, Maldives, Nepal, and Sri Lanka.

7 Primary to lower secondary school age.
} 


\section{A. School Enrollments and Educational Attainment}

Figure 5 shows the overall trend in gross enrollment ratios by level among school-age population group. Since the 1960s, enrollment ratios at the primary and secondary levels have rapidly increased across Southeast Asian countries, allowing them to catch up with other Asian countries, and even close the gap at the primary level. Notably, Sri Lanka has shown strong growth in secondary enrollment ratios, surpassing many other Asian economies. However, a huge enrollment disparity still remains between South Asia (including Sri Lanka) and other Asian countries at the higher levels, especially at the tertiary level where South Asia had limited progress throughout the period.

Table 6 shows that, although South Asian countries have notably increased access to schooling between 1960 and 2010, as well as their average educational attainment, all except Sri Lanka remain less-educated than their most Asian counterparts. As of 2010, the average years of schooling among the population aged between 15 and 64 years was only 4.2 years in Nepal, over 6 years in both Bangladesh and India, and over 10 years in Sri Lanka. The average number of years of schooling in Nepal in 2010 is similar to the Republic of Korea's educational level in the 1960s, while that of Bangladesh and India are similar to the Republic of Korea's attainment in the 1970s. In contrast, the current level of educational attainment in Sri Lanka, which is only lower than the current level in Singapore, is around the same as that of the Republic of Korea's attainment in the 1990s.

As of 2010, majority of the population aged 15-64 (79.4\%) in Sri Lanka had some secondary education or higher, and only a marginal share had never attended school. In contrast, while $30 \%-50 \%$ of the population aged 15-64 in Bangladesh, India, and Nepal had some secondary education or higher, around one-third remained uneducated. This striking observation suggests that gaps in access to schooling remain a serious concern for most of South Asia.

Although South Asia made significant progress toward achieving universal primary education (MDG 2), efforts continue to ensure that children, boys and girls alike, will be able to complete a full course of primary schooling (MDG 2A), and eliminate gender disparities at all levels of education (MDG 3A). Countries in South Asia have managed to narrow gender disparities in educational access as in other Asian economies. Latest gross enrollment figures suggest that they have brought the female-to-male ratio in enrollment or gender parity index closer to 1 (i.e., equal ratios for males and females) at the start of the decade 2010-2019, especially at the primary and secondary levels (Table 7). However, except in Sri Lanka, the gender parity index remains far from 1, especially at the tertiary level. This implies that in Bangladesh, India, and Nepal, girls have less chances of entering and staying in school than boys do, especially at the tertiary level. 


\section{Figure 5: Gross Enrollment Ratios (Total, \%)}

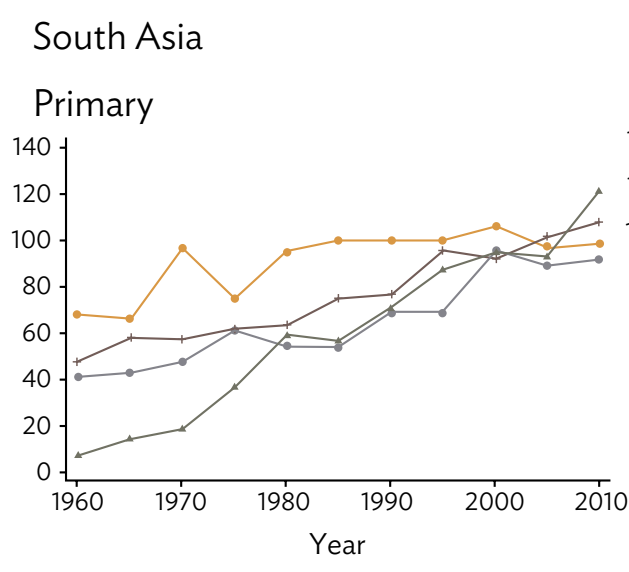

$\multimap$ Bangladesh — India $\_$Nepal $\_$Sri Lanka

Secondary

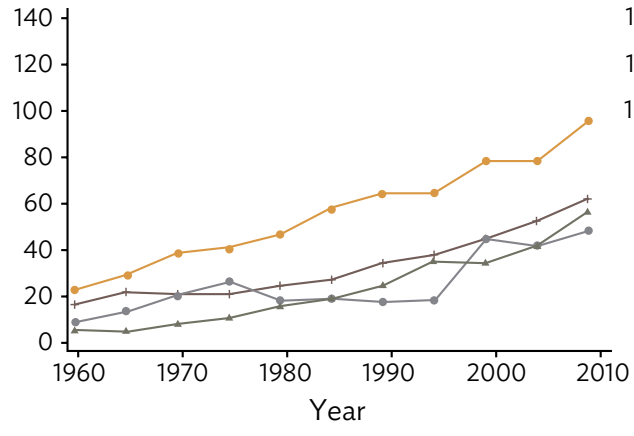

$\multimap$ Bangladesh $\longrightarrow$ India $\longrightarrow$ Nepal $\multimap$ Sri Lanka

Tertiary

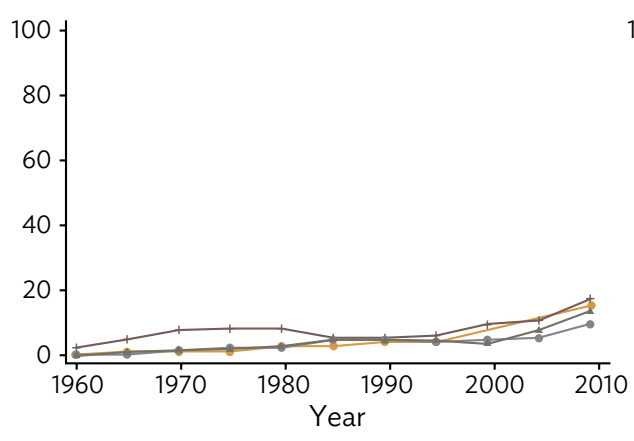

$\multimap$ Bangladesh — India $\longleftarrow$ Nepal — Sri Lanka

\section{Other Asian countries}

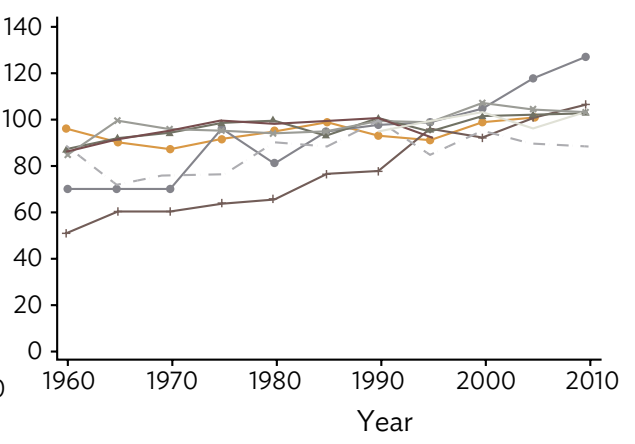

$\ldots$ China, People's Rep. of — Korea, Rep. of —India —Malaysia „_Philippines _Singapore _ _ - Thailand __ Viet Nam

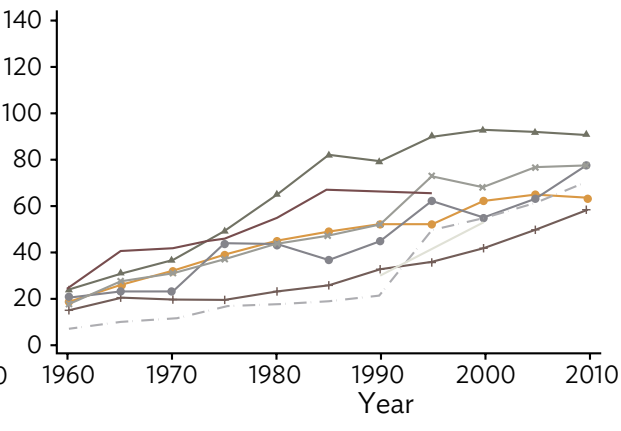

$\ldots$ China, People's Rep. of —_Korea, Rep. of India $\multimap$ Malaysia $\multimap$ Philippines
Singapore $\ldots$ - Thailand $\rightleftharpoons$ Viet Nam

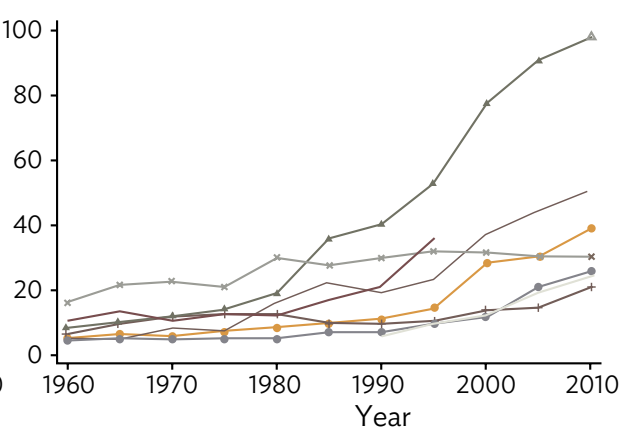

$\longrightarrow$ China, People's Rep. of —_Korea, Rep. of

—_India —Malaysia \# Philippines

_Singapore _ _ - Thailand__ Viet Nam

Notes: Total gross enrollment ratio is the proportion of total enrolled students in the relevant education level to the population of the relevant education age group. It can exceed $100 \%$ due to the inclusion of overaged and underaged students because of early or late school entrance and grade repetition.

Source: Barro and Lee (2013). 
Table 6: Educational Attainment

\begin{tabular}{|c|c|c|c|c|c|c|c|c|c|}
\hline \multirow{4}{*}{$\begin{array}{l}\text { Region, } \\
\text { Country, } \\
\text { and Year }\end{array}$} & \multirow{4}{*}{$\begin{array}{l}\text { Average } \\
\text { Years of } \\
\text { Schooling }\end{array}$} & \multirow{4}{*}{$\begin{array}{l}\text { Population } \\
\text { Aged } \\
15-64 \\
\text { (million) }\end{array}$} & \multicolumn{7}{|c|}{ Highest Level Attained } \\
\hline & & & \multirow{2}{*}{$\begin{array}{c}\text { No } \\
\text { Schooling }\end{array}$} & \multicolumn{2}{|c|}{ Primary } & \multicolumn{2}{|c|}{ Secondary } & \multicolumn{2}{|c|}{ Tertiary } \\
\hline & & & & Total & Comp. & Total & Comp. & Total & Comp. \\
\hline & & & \multicolumn{7}{|c|}{ (\% of population aged $15-64)$} \\
\hline \multicolumn{10}{|c|}{ South Asia } \\
\hline \multicolumn{10}{|c|}{ Bangladesh } \\
\hline 1960 & 1.02 & 30 & 77.2 & 16.8 & 2.0 & 5.8 & 2.2 & 0.3 & 0.2 \\
\hline 1980 & 2.25 & 47 & 66.8 & 17.3 & 15.7 & 14.8 & 5.0 & 1.1 & 0.6 \\
\hline 2000 & 4.69 & 81 & 43.2 & 22.7 & 21.1 & 30.5 & 18.4 & 3.6 & 2.2 \\
\hline 2010 & 6.04 & 104 & 31.9 & 22.3 & 21.4 & 41.7 & 25.2 & 4.1 & 2.5 \\
\hline \multicolumn{10}{|l|}{ India } \\
\hline 1960 & 1.13 & 266 & 72.1 & 24.8 & 8.6 & 2.5 & 0.2 & 0.6 & 0.3 \\
\hline 1980 & 2.35 & 423 & 66.3 & 12.7 & 7.8 & 18.7 & 0.5 & 2.3 & 1.3 \\
\hline 2000 & 5.04 & 673 & 44.2 & 16.2 & 13.5 & 32.5 & 19.7 & 7.1 & 4.4 \\
\hline 2010 & 6.26 & 829 & 33.2 & 16.8 & 15.1 & 41.5 & 24.3 & 8.5 & 5.2 \\
\hline \multicolumn{10}{|l|}{ Nepal } \\
\hline 1960 & 0.13 & 6 & 98.3 & 0.6 & 0.2 & 1.1 & 0.3 & 0.2 & 0.1 \\
\hline 1980 & 0.99 & 9 & 85.1 & 6.8 & 2.8 & 6.9 & 1.2 & 1.2 & 0.6 \\
\hline 2000 & 2.97 & 14 & 53.9 & 22.3 & 11.4 & 21.0 & 7.9 & 2.9 & 1.8 \\
\hline 2010 & 4.23 & 19 & 36.2 & 31.1 & 18.9 & 29.8 & 12.6 & 2.9 & 1.8 \\
\hline \multicolumn{10}{|l|}{ Sri Lanka } \\
\hline 1960 & 4.00 & 6 & 29.7 & 46.6 & 6.9 & 23.4 & 11.7 & 0.4 & 0.2 \\
\hline 1980 & 7.00 & 10 & 13.5 & 44.7 & 26.3 & 41.1 & 26.6 & 0.8 & 0.5 \\
\hline 2000 & 10.36 & 15 & 8.7 & 13.7 & 8.8 & 64.3 & 48.1 & 13.3 & 7.9 \\
\hline 2010 & 10.25 & 17 & 4.3 & 16.3 & 10.6 & 64.8 & 18.0 & 14.6 & 8.6 \\
\hline \multicolumn{10}{|c|}{ Other Asian countries } \\
\hline \multicolumn{10}{|c|}{ China, People's Republic of } \\
\hline 1960 & 2.43 & 402 & 56.9 & 29.6 & 12.5 & 12.8 & 2.9 & 0.7 & 0.4 \\
\hline 1980 & 4.91 & 644 & 24.8 & 40.7 & 22.4 & 33.7 & 10.2 & 0.9 & 0.5 \\
\hline 2000 & 7.04 & 958 & 10.9 & 30.4 & 17.8 & 54.1 & 31.1 & 4.6 & 2.7 \\
\hline 2010 & 7.58 & 1091 & 5.2 & 23.7 & 14.1 & 66.7 & 22.9 & 4.4 & 2.5 \\
\hline \multicolumn{10}{|c|}{ Korea, Republic of } \\
\hline 1960 & 4.22 & 15 & 42.6 & 36.9 & 33.3 & 17.8 & 7.9 & 2.6 & 1.5 \\
\hline 1980 & 8.26 & 25 & 13.1 & 28.0 & 26.9 & 49.8 & 28.0 & 9.1 & 4.7 \\
\hline 2000 & 11.11 & 37 & 6.0 & 11.9 & 11.2 & 51.9 & 40.5 & 30.2 & 16.8 \\
\hline 2010 & 12.10 & 41 & 3.7 & 10.0 & 9.2 & 44.2 & 36.1 & 42.0 & 30.2 \\
\hline \multicolumn{10}{|l|}{ Indonesia } \\
\hline 1960 & 1.59 & 58 & 67.4 & 29.0 & 12.3 & 3.5 & 0.7 & 0.1 & 0.1 \\
\hline 1980 & 3.68 & 89 & 31.9 & 55.1 & 22.1 & 12.4 & 5.3 & 0.6 & 0.3 \\
\hline
\end{tabular}


Table 6 continued

\begin{tabular}{|c|c|c|c|c|c|c|c|c|c|}
\hline \multirow{4}{*}{$\begin{array}{l}\text { Region, } \\
\text { Country, } \\
\text { and Year }\end{array}$} & \multirow{4}{*}{$\begin{array}{l}\text { Average } \\
\text { Years of } \\
\text { Schooling }\end{array}$} & \multirow{4}{*}{$\begin{array}{l}\text { Population } \\
\text { Aged } \\
15-64 \\
\text { (million) }\end{array}$} & \multicolumn{7}{|c|}{ Highest Level Attained } \\
\hline & & & \multirow{2}{*}{$\begin{array}{c}\text { No } \\
\text { Schooling }\end{array}$} & \multicolumn{2}{|c|}{ Primary } & \multicolumn{2}{|c|}{ Secondary } & \multicolumn{2}{|c|}{ Tertiary } \\
\hline & & & & Total & Comp. & Total & Comp. & Total & Comp. \\
\hline & & & \multicolumn{7}{|c|}{ (\% of population aged $15-64$ ) } \\
\hline 2000 & 5.16 & 146 & 22.4 & 56.3 & 37.5 & 19.4 & 9.8 & 2.0 & 1.3 \\
\hline 2010 & 7.65 & 173 & 7.5 & 43.8 & 29.1 & 42.3 & 22.4 & 6.4 & 4.1 \\
\hline \multicolumn{10}{|l|}{ Malaysia } \\
\hline 1960 & 2.86 & 4 & 50.0 & 38.4 & 14.8 & 10.0 & 3.2 & 1.5 & 0.5 \\
\hline 1980 & 5.76 & 8 & 26.9 & 37.9 & 20.7 & 31.7 & 15.4 & 3.5 & 0.9 \\
\hline 2000 & 9.22 & 15 & 10.7 & 22.2 & 13.9 & 56.9 & 35.7 & 10.3 & 3.1 \\
\hline 2010 & 10.38 & 19 & 7.1 & 18.6 & 11.8 & 56.1 & 39.7 & 18.2 & 5.5 \\
\hline \multicolumn{10}{|c|}{ Philippines } \\
\hline 1960 & 3.46 & 15 & 26.0 & 53.4 & 16.8 & 14.3 & 7.4 & 6.3 & 3.6 \\
\hline 1980 & 6.16 & 27 & 8.6 & 48.9 & 22.3 & 26.3 & 11.8 & 16.3 & 8.2 \\
\hline 2000 & 7.86 & 47 & 5.3 & 32.9 & 18.1 & 35.8 & 18.0 & 25.9 & 6.5 \\
\hline 2010 & 8.40 & 61 & 2.7 & 27.2 & 15.9 & 46.4 & 22.4 & 23.7 & 5.9 \\
\hline \multicolumn{10}{|l|}{ Singapore } \\
\hline 1960 & 3.72 & 1 & 49.4 & 27.0 & 10.3 & 22.1 & 7.5 & 1.5 & 1.2 \\
\hline 1980 & 5.28 & 2 & 29.8 & 38.4 & 19.0 & 28.5 & 9.9 & 3.3 & 2.7 \\
\hline 2000 & 9.33 & 3 & 18.1 & 11.5 & 6.0 & 54.6 & 43.5 & 15.7 & 13.6 \\
\hline 2010 & 10.74 & 4 & 14.8 & 6.8 & 3.6 & 44.4 & 34.3 & 33.9 & 27.4 \\
\hline \multicolumn{10}{|l|}{ Thailand } \\
\hline 1960 & 2.58 & 15 & 37.2 & 55.1 & 42.5 & 7.0 & 1.8 & 0.7 & 0.3 \\
\hline 1980 & 3.77 & 28 & 14.2 & 70.4 & 4.0 & 12.3 & 4.3 & 3.1 & 2.8 \\
\hline 2000 & 5.74 & 46 & 13.1 & 58.3 & 20.2 & 22.6 & 11.0 & 6.0 & 5.0 \\
\hline 2010 & 7.90 & 52 & 3.4 & 47.9 & 18.2 & 35.5 & 19.7 & 13.3 & 10.8 \\
\hline \multicolumn{10}{|l|}{ Viet Nam } \\
\hline 1960 & 2.86 & 20 & 44.3 & 38.3 & 13.8 & 16.9 & 4.6 & 0.5 & 0.3 \\
\hline 1980 & 5.13 & 31 & 20.5 & 37.7 & 17.6 & 40.9 & 11.7 & 0.9 & 0.5 \\
\hline 2000 & 5.65 & 52 & 10.8 & 52.7 & 30.6 & 32.5 & 9.4 & 4.0 & 2.3 \\
\hline 2010 & 7.15 & 66 & 15.2 & 22.3 & 13.0 & 56.8 & 19.7 & 5.7 & 3.6 \\
\hline
\end{tabular}

Source: Barro and Lee (2013). 
Table 7: Gender Parity Index by Level

(female gross enrollment ratio/male gross enrollment ratio)

\begin{tabular}{|l|c|c|c|c|}
\hline \multirow{2}{*}{ Region and Country } & \multicolumn{3}{|c|}{ Level } \\
\cline { 2 - 5 } & Pre-Primary & Primary & Secondary & Tertiary \\
\hline South Asia & & & & \\
\hline Bangladesh & 0.98 & 1.06 & 1.14 & 0.72 \\
\hline India & 1.05 & 1.02 & 0.94 & 0.78 \\
\hline Nepal & 0.96 & 1.09 & 1.06 & 0.64 \\
\hline Sri Lanka & 1.00 & 1.00 & 1.06 & 1.66 \\
\hline Other Asian countries & & & & \\
\hline China, People's Rep. of & 1.00 & 1.00 & 1.02 & 1.13 \\
\hline Indonesia & 1.04 & 1.00 & 1.03 & 1.03 \\
\hline Philippines & 1.02 & 0.98 & 1.08 & 1.24 \\
\hline Viet Nam & 0.95 & 1.01 & - & 0.90 \\
\hline
\end{tabular}

- = data not available.

Note: Figures reflected are most recent data from 2009 to 2012.

Source: United Nations Educational, Scientific and Cultural Organization Institute for Statistics (2015).

Current educational achievements across South Asian countries still reflect the significant disparities in school access, participation, and completion in earlier decades in the region (Figure 6). Unlike in most countries in South Asia, where greater access to basic education helped reduce the gender disparity in educational achievement over time, gender disparity in educational attainment continue to widen in India. The difference in average years of schooling between males and females in India increased by half a year to 2.7 years in 2010 from 1990.

School completion rates in the region are also low. Many of those who enroll in school drop out sooner or later. In India, for instance, seven in every 20 students who started school do not reach grade 10 (Sabharwal 2013). Of the 26 million who take the grade 10 exit examinations, 10 million fail to clear them. Half of the 16 million who take the grade 12 examinations do not pass. Only 5 million of the 8 million who successfully go past grade 12 examinations go on to college. In Bangladesh, only 66 out of 100 students -62 males and 71 females - survive to the last grade of primary education. The survival ratio in Sri Lanka is much higher (97\%), although the ratio is much higher among male students (100\%) than among female students (95\%). 
Figure 6: Educational Attainment

(average years of schooling)

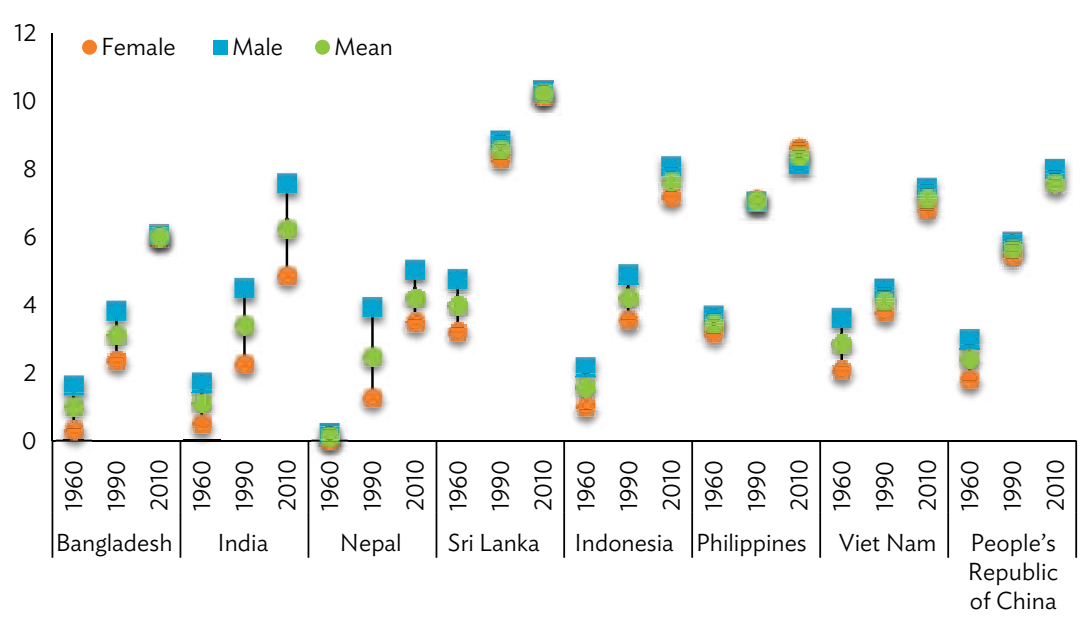

Source: Barro and Lee (2014).

\section{B. Quality of Education}

Though important, simply narrowing the gaps in enrollment ratios and years of schooling is not enough. Education, if successful, transforms lives. Quality of education, which is not captured by these quantitative measures, is a very important determinant of workers' productivity and economic growth (Hanushek and Woessman 2007, 2008). It reduces poverty - a pervasive barrier to school attendance and learning-and, if broad-based, it can potentially improve income distribution (Aslam et al. 2012, Hanushek and Woessman 2012, Fasih et al. 2012, Bhatta and Sharma 2011). Higher and better education among parents, especially among mothers, translates into lower maternal deaths, better health and nutrition among children (e.g., lower stunting), and higher school participation and better cognitive development among children (Bhalotra and Clarke 2013, Bhalotra et al. 2013, Headey 2013, Sabates 2013, Behrman et al. 2009, Semba et al. 2008). ${ }^{8}$

In South Asia, while educational investments have led to large improvements in access and reduction in enrollment gaps, they have not translated into better learning outcomes. Indicated by low learning outcomes in comparison with international standards, quality of education remains poor across different levels of education (Dundar et al. 2014, Panagariya 2008), and it undermines South Asia's competitiveness and economic growth, especially at this day and age of rapidly evolving technology. Nonetheless, South Asian governments are increasingly recognizing that to fully realize the expected returns on their investments, and generate gains in labor productivity and income, a greater focus on improving education is essential.

8 See UNESCO 2014 for a review of related literature. 
Beyond school participation and completion, the goal for education is ultimately to improve learning, as well as develop both cognitive and noncognitive skills. Thus, as United Nations Educational, Scientific and Cultural Organization (2014) puts it, while improving access, governments should also ensure that children are learning in school. Recent literature has clearly shown that a substantial part of the variation in labor market outcomes between individuals and differences in economic growth rates between countries can be explained by the quality, rather than the quantity, of schooling (World Bank 2014). For instance, in Pakistan, a 1 standard deviation increase in cognitive skills, as measured by cognitive achievement test scores, is associated with a $25 \%$ increase in earnings (Behrman et al. 2008).

The weight of evidence points to the urgent need to shift South Asia's efforts beyond increasing educational access, and toward a greater focus on improving learning outcomes, especially at the primary and secondary levels, as well as narrowing regional and social gaps in learning that start at the point of entry and expand through higher levels (Dundar et al. 2014). Beyond increasing school access and quality, ensuring that all children can learn also requires addressing disparities and inadequacies among children at an early age. Getting them off to the right start means addressing early gaps in health, nutrition, and education (World Bank 2013, 2015). For instance, as shown in Figure 7, the prevalence of malnutrition, as measured by the proportion of underweight, is especially very high among poor children under 5 years old in South Asian countries. In India, and similarly in Bangladesh, one in every two children 5 years old and below from poor households (bottom 40\%) is not getting enough nourishment that is required to reach the appropriate weight.

Investing early in health, nutrition, and education, especially of those disadvantaged children, helps address early gaps in cognitive skills which have serious short-term

Figure 7: Prevalence of Underweight Children (\% of malnourished children under 5 by wealth quantile)

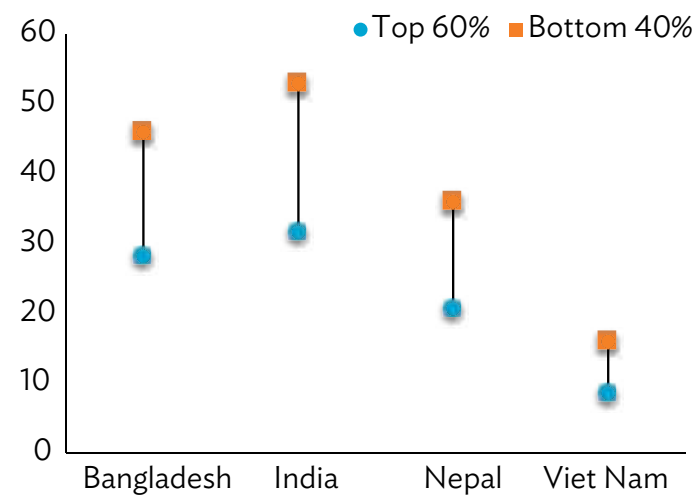

Notes: Figures for all countries, except for India, are as of 2011. Data for India is as of 2006.

Source: Author's estimate based on data from the World Bank's Health and Nutrition Database by Wealth Quintile database. 
(e.g., school readiness and achievement) and long-term cognitive consequences (e.g., lifelong learning, employability, and productivity) (Alderman et al. 2006, Cunha et al. 2006, Carneiro and Heckman 2003). For instance, low cognitive development in early childhood is associated with a higher likelihood of illness, grade repetition, and school dropout, and poor labor outcomes (Heckman and Masterov 2007, Feinstein 2003, Currie and Thomas 1999, Pianta and McCoy 1997). ${ }^{9}$

In addition to the 21 million children aged 8-14 years in South Asia who are not enrolled in school and the large proportion of working-age population who has never attended school, those who are in school are not acquiring the basic cognitive skills they need (UIS 2015, Dundar et al. 2014, Lee 2014b, Barro and Lee 2013). These basic skills, such as literacy and numeracy, problem-solving ability, and general scientific knowledge, are crucial for either continuing their education or performing productive jobs.

In India, regional and social disparities in access to good quality education are a serious concern, especially in poorer rural areas. Furthermore, inadequate education at the secondary and tertiary levels, including technical and vocational education and training result in job market mismatches. On the one hand, there are students unequipped to meet the job market's changing demands, and employers are struggling to seek workers with the appropriate skills on the other.

The achievement of students and graduates is a usual measure of school quality. However, because most countries in South Asia do not participate in international student assessments, the data to compare learning outcomes within the region with those in other regions is not available. Nonetheless, the results of the Programme for International Student Assessment $(\mathrm{PISA})^{10}$ study are illustrative of the poor level of learning among students in Tamil Nadu and Himachal Pradesh in India. As shown in Table 8, out of 74 groups of students across different locations worldwide, the two Indian states ranked poorly in all subjects (mathematics, reading, and science).

In most countries in the region, except in Sri Lanka, most students perform poorly in nationally administered achievement tests. Student performance can also vary widely across regions and subjects. For example, in an achievement test administered among grade 5 students across India between March and May 2010 (National Council of Educational Research and Training [NCERT] 2011), ${ }^{11}$ only around half of students were able to correctly identify the cause of an event, and only less than a third could read with understanding and make inferences. Their mathematics test scores show that only a third could compute the difference between two decimal numbers. The educational assessment survey also revealed wide disparity in achievement levels, and therefore inequity in learning outcomes, among students and between states. Furthermore, students from minority groups-castes, tribes, and other backward categories-scored significantly lower than other students.

9 See Alderman (2011) for a detailed review of evidence on the long-term consequences of early child development from countries of different income groups.

10 Administered by the International Association for the Evaluation of Educational Achievement, PISA is a triennial international survey among 15-year-old students in randomly selected schools to measure students' competencies and evaluate education systems in participating economies worldwide.

11 This refers to National Achievement Survey, the most comprehensive educational assessment survey in India, which was conducted by the National Council of Educational Research and Training. 
Table 8: Programme for International Student Assessment (mean score and rank)

\begin{tabular}{|l|r|r|r|r|r|r|}
\hline \multirow{2}{*}{ Location } & \multicolumn{2}{|c|}{ Mathematics } & \multicolumn{2}{c|}{ Reading } & \multicolumn{2}{c|}{ Science } \\
\cline { 2 - 7 } & 2009 Plus & \multicolumn{1}{|c|}{2012} & 2009 Plus & 2012 & 2009 Plus & 2012 \\
\hline $\begin{array}{l}\text { Shanghai, People's } \\
\text { Republic of China }\end{array}$ & $600(1)$ & $613(1)$ & $556(1)$ & $570(1)$ & $575(1)$ & $580(1)$ \\
\hline Singapore & $562(2)$ & $573(2)$ & $526(5)$ & $542(3)$ & $542(4)$ & $551(3)$ \\
\hline Hong Kong, China & $555(3)$ & $561(3)$ & $533(4)$ & $545(2)$ & $549(3)$ & $555(2)$ \\
\hline Korea, Republic of & $546(4)$ & $554(5)$ & $539(2)$ & $536(5)$ & $538(6)$ & $538(7)$ \\
\hline Taipei,China & $543(5)$ & $560(4)$ & $495(23)$ & $523(8)$ & $520(12)$ & $523(13)$ \\
\hline Japan & $529(9)$ & $536(7)$ & $520(8)$ & $538(4)$ & $539(5)$ & $547(4)$ \\
\hline Macau, China & $525(12)$ & $538(6)$ & $487(28)$ & $509(16)$ & $511(18)$ & $521(17)$ \\
\hline Germany & $513(16)$ & $514(16)$ & $497(19)$ & $508(20)$ & $520(13)$ & $524(12)$ \\
\hline Viet Nam & & $511(17)$ & & $508(19)$ & & $528(8)$ \\
\hline United Kingdom & $492(28)$ & $494(26)$ & $494(25)$ & $499(23)$ & $514(16)$ & $514(20)$ \\
\hline United States & $487(31)$ & $481(36)$ & $500(15)$ & $498(24)$ & $502(23)$ & $497(28)$ \\
\hline Russian Federation & $468(38)$ & $482(34)$ & $459(52)$ & $475(41)$ & $478(41)$ & $486(37)$ \\
\hline Thailand & $419(52)$ & $427(50)$ & $421(53)$ & $441(47)$ & $425(51)$ & $444(48)$ \\
\hline Malaysia & $404(57)$ & $421(52)$ & $414(55)$ & $398(59)$ & $422(53)$ & $420(53)$ \\
\hline Indonesia & $371(68)$ & $375(64)$ & $402(62)$ & $396(60)$ & $383(66)$ & $382(64)$ \\
\hline Tamil Nadu, India & $351(72)$ & - & $337(72)$ & - & $348(72)$ & - \\
\hline Himachal Pradesh, India & $338(73)$ & - & $317(73)$ & - & $325(74)$ & - \\
\hline
\end{tabular}

- = data not available.

Notes: Figures in parentheses are rankings. Participants in Programme for International Student Assessment 2009 Plus are 74 economies and Programme for International Student Assessment 2012 are 65 economies.

Sources: OECD (2012a) and Walker (2011).

In Bangladesh, a student assessment administered in $2011^{12}$ indicated that more than one-third of grade 5 students tested did not even have grade 3 competencies (World Bank 2013). Only one in every three grade 5 students have mastered the mathematics competencies expected in the national curriculum, and only one in every four students have mastered Bangla (World Bank 2013). An earlier assessment in rural Bangladesh showed that only $80 \%-90 \%$ of students who have completed grade 9 have basic grade 5 competencies in oral and written mathematics (Asadullah et al. 2009).

In Nepal, national assessments of grade 5 and grade 8 students in 2008 revealed that, similar to other students in South Asia, the general level of competence of students in Nepal across core subjects (including on core subjects of Nepali, English, and mathematics) was below satisfactory (Dundar et al. 2014). ${ }^{13}$ As shown in Figure 8, mean student

\footnotetext{
12 Bangladesh's 2011 National Student Assessment.

132008 national assessment of grade 5 students and the Educational and Developmental Services Centre's national assessment of grade 8 students in Nepal.
} 
performance varies widely across regions and across subjects, and is especially very low in mathematics among grade 8 students.

In contrast, learning outcomes in Sri Lanka-where school participation is historically high-are encouragingly more progressive than the rest of South Asia. A 2009 assessment test administered nationwide revealed that a relatively large proportion of grade 4 students were able to master essential learning competencies specified in the national curriculum, registering an average mean achievement score in mathematics of 77\% in Sinhala-medium schools and 62\% in Tamil-medium schools (National Education Research and Evaluation Center [NEREC] 2009). It is nonetheless interesting to note that test scores were 14\%-18\% lower in English than in first-language competency, and that scores are consistently lower among students from Tamil-medium schools, which suggests income disparities in learning outcomes (Dundar et al. 2014).

Aside from the wide disparities in learning outcomes, the decline in mean achievement test scores in India, and in most of South Asia (except in Sri Lanka), over time is also an indicator of the quality of education in South Asia. For instance, Annual Status of Education Report assessments in India revealed that the proportion of grade 3 students who can read grade 1 text fell from 48\% in 2006 to 40\% in 2011. Similarly, among grade 5 students, the proportion of those who can read grade 2 text fell from $53 \%$ to 48\% between 2006 and 2011. The decline was even steeper in the case of arithmetic achievement test scores during the same period: the proportion of grade 3 students who are able to perform subtraction fell from $45 \%$ to $28 \%$, while those in grade 5 who can perform division went down from $49 \%$ to $30 \%$. While a similar trend can be observed in Bangladesh, a more encouraging pattern can be seen in Sri Lanka.

Figure 8: Mean Achievement Test Scores of Grade 5 and Grade 8 Students in Nepal by Subject and Region (\%)

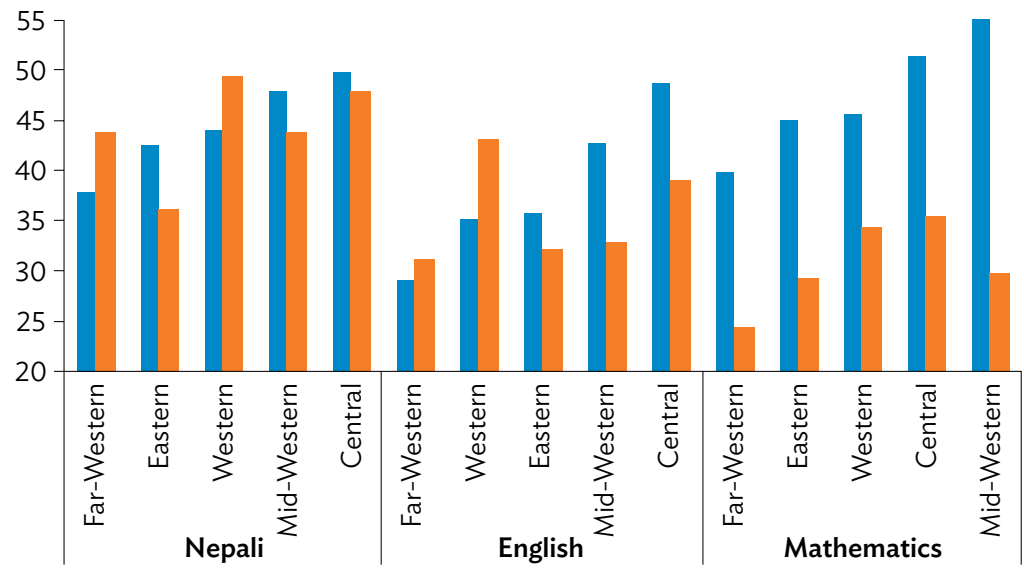

Grade 5 Grade 8

Source: Dundar et al. (2014). 
Poor student performance in national assessments is a glaring indication that many teachers in South Asia are still unable to explain basic concepts, and thus transmit knowledge to their pupils. While it is unclear what makes a good teacher (Box 4), there is consensus that good teaching is important for better performance. No other school inputs are as important as teachers in influencing learning outcomes (Hanushek 2011). Some teachers are more successful than others in generating greater learning among students. Because these gains accumulate through the years, a bad year could have implications on the ability of students to gain more learning in subsequent academic years.

Although learning is influenced by many other factors, motivated teachers capable of not only imparting knowledge, but also supporting students to develop their cognitive and noncognitive skills, especially weak learners, play an important role (Hanushek et al. 2009, Goldhaber and Brewer 1999, Card and Krueger 1992, Behrman and Birdsall 1983)..$^{14}$ Aside from the large variation in students' achievement across OECD countries, teachers' skills also explain around $14 \%$ of the large variation in mathematics achievement test scores at the country level, and 17\% for reading (Meroni et al. 2015).

In South Asia, more than is typical in other regions of the world, about one-half to twothirds of the variation in student achievement in many countries can be attributed to school-specific factors, such as teachers, and school resources (Dundar et al. 2014). As in the case of student achievement, data to compare teacher quality in the region with those in other regions is unavailable. Some of the indicators that are typically used as a measure of quality or effectiveness of teaching include years of schooling, achievement test score, teaching certification, teaching experience, in-service training, and salary. However, as discussed in Box 4, the evidence on the relationship between these measures and teacher effectiveness is inconclusive.

Except in Bangladesh, average class size at the primary level in South Asia is generally comparable with other developing countries (Figure 9). It is, however, worrying that a significant proportion of the teachers are untrained. Around two in every 10 primary school teachers in Maldives, Nepal, and even in Sri Lanka lack training. The ratio of students to trained teachers in these countries is much higher than what is typical in other Asian countries. An outlier, Bangladesh has a very high primary pupil-to-teacher ratio (40 pupils per teacher) and, at the same time, a very low proportion of trained primary teachers (only six in every 10 are trained).

Although, the impact of pupil-to-teacher ratio on average student achievement is less clear, reductions in class size benefit those with less ability to learn (Bosworth 2014, Cho et al. 2012, Hanushek 2011, Mishel and Rothstein 2002, Ehrenberg et al. 2001, Krueger 1999). In the United States, evidence shows that reductions in class size greatly benefit students who struggle in school, as well as those who belong to minorities and poorer families (Bosworth 2014, De Paola et al. 2012, Krueger 1999). It is not difficult to think that teachers, even if well trained, may find it very challenging to identify and closely support weak learners when handling large classes. In addition, teachers who lack the proper training, as those in South Asia, may find it difficult, if not impossible, to do so.

14 Recent studies have shown that differences in school systems and institutional characteristics play an important role in explaining cross-country differences in students' performances (Hanushek and Woessman 2011). 


\section{Box 4: What Makes a Good Teacher?}

What attributes should a teacher possess to achieve better learning among students? Teachers' formal education and experience are some of the attributes that are commonly considered in hiring and rewarding teachers. However, hundreds of research studies have found little or no evidence that these observable characteristics and others (e.g., subject knowledge and certification) are related to teacher effectiveness or student outcomes.

Some studies suggest, nonetheless, that teachers with better verbal and cognitive ability tend to be more effective in the classroom. Similarly, some studies have found that teacher quality in terms of what teachers know about the subject matter (subject matter knowledge) and are able to teach (pedagogical skill) are somehow both positively related to student achievement. Evidence also suggests that skills of teachers, including literacy, numeracy, and problem-solving measured at the country level using Programme for the International Assessment of Adult Competencies, are positively associated with learning outcomes among students, as measured using Programme for International Student Assessment, in Organisation for Economic Co-operation and Development countries.

Sources: Harris and Sass 2011; Hanushek 2011; Hanushek and Rivkin 2006; Glewwe and Kremer 2006; Santiago 2002; Hanushek 1971; Aloe and Becker 2009; Andrew et al. 2005; Baumert et al. 2010; Rice 2003; Monk 1994; Meroni et al. 2015.

To make matters worse, absenteeism - a symptom of having poorly motivated workersamong teachers is also pervasive in South Asia (Wan and Francisco 2009, Dundar et al. 2014). Absenteeism rates among teachers in South Asia range from around $15 \%$ to $25 \%$ (Dundar et al. 2014). Due to the lack of motivated and well-trained teachers, learning in the region is mainly procedural. Although students can read and comprehend written material, they have trouble expressing thoughts in their own words. Although they can recognize numbers and perform mathematical operation, they cannot relate the concepts to real life.

\section{Figure 9: Class Size and Trained Teachers in Primary Schools}

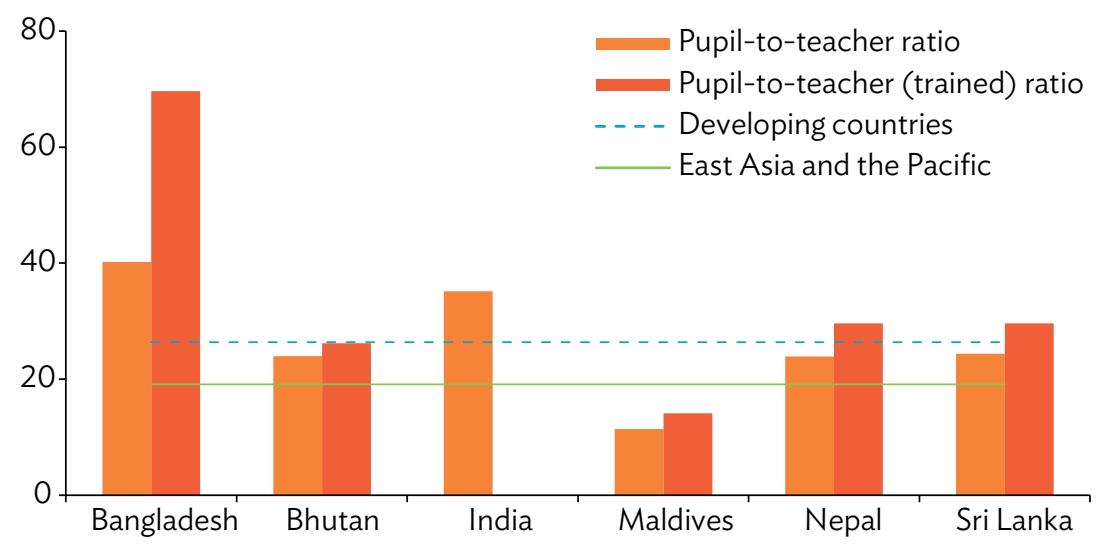

Source: United Nations Educational, Scientific and Cultural Organization Institute for Statistics Database (2015). 
Student and household characteristics, such as gender and nutritional status, the language spoken at home, parental education, household income, and social status, are also strong determinants of academic performance in South Asia, as in other parts of the world (Dundar et al. 2014, Lee 2014b). In addition, school-specific factors, such as teacher quality, class size, expenditure per pupil, instruction time, and the amount of school resources available to students, also play a greater role in student achievement in many South Asian countries than is typical in other regions of the world (Dundar et al. 2014). The institutional features of education systems, such as private financing and provision, school autonomy, and external monitoring and assessment mechanisms, also tend to influence the quality of education by changing the incentives for students and teachers (Lee 2014b).

Although the test scores of students reflect the quality of schooling, and hence indicate the quality of the labor force, they do not directly measure the educational capital held by a country's working-age population. The measure of students' educational attainment does not take into account the skills and experience gained by individuals after their formal schooling. Knowledge can be also lost after the completion of formal education. Ideally, tests of cognitive ability would be administered to adults rather than students. There have been attempts to directly measure the skills of the labor force across countries through the International Adult Literacy Survey (IALS), Adult Literacy and Life Skills Survey, and Programme for the International Assessment of Adult Competencies (PIAAC). Unfortunately, not many Asian economies have participated in these adult skill tests. The existing survey data will be particularly in the Republic of Korea, to assess the link between formal education and adult skills.

\section{Higher Education and Employability of Graduates}

As emphasized in Section II, higher education contributes significantly to the technological capacity and overall competitiveness of an economy. While only a small proportion of high school graduates would intend to pursue college or university education, efforts to provide high-quality higher education for a sufficient number of secondary school graduates, especially in the fields of science and technology, as well as extending access in ways that promote better equity, are important for promoting and sustaining growth in the region.

Aside from having low gross enrollment ratio at the tertiary level (10.4\% in Bangladesh, $14.3 \%$ in Nepal, $16.9 \%$ in Sri Lanka, and 18\% in India), many young workers in the region are failing to develop the right skills for today's job market (section IV extends this discussion to vocational education). For example, a survey of large and small industrial companies across India has found that more than three in every five companies hiring fresh engineering graduates are either only somewhat satisfied or dissatisfied with the quality of skills of their new hires (Blom and Saeki 2011). Employers in India perceive soft skillscore values (e.g., integrity, reliability, flexibility) and communication skills (e.g., written and oral communication, computer skills) - to be very important. Skill gaps in India are most severe in the higher-order thinking skills, and least in English communication-one of the most demanded skills by the employers. Similar data and analysis on other countries in the region, although useful, are lacking.

The concern on the lack of employability of graduates is also shared by other Asian countries. For instance, in the PRC where a rapid expansion in tertiary enrollment has been observed in recent years, unemployment among graduates from top-tier universities 
was around $10 \%$ or more than twice the overall unemployment rate in the country in 2008 (ADB 2012d). This figure was even higher for graduates of the other colleges and universities (13\%) and of technical-vocational colleges (16\%). ${ }^{15}$ In Thailand, where the education system skews toward social science rather than science, technology, and health science, four in every five firms report difficulties in finding employees with adequate technical skills (ADB 2012d, World Bank 2011b).

The quality of tertiary graduates in South Asia has been affected mainly by three factors. One factor that contributed to the low quality of tertiary education in the region is the rapid universalization which caused the limited public resources to be thinly spread across a large number of public institutions. Another factor is the limited regulatory capacity of the government to maintain standards as private sector institutions grow rapidly. Finally, the lack of responsiveness of tertiary institutions to the changing demands of the industry and the economy results in a mismatch between the courses that most students take and the jobs of today's labor market. Consequently, a large proportion of the number of youth globally who are not in education, training, or employment are in South Asia (ADB 2013a).

Employability of tertiary graduates is largely influenced by what students are studying and the skills that they are able to form, and how well aligned it is with the demands of the labor market (see Box 5 for a discussion on East Asia and Southeast Asia). As shown in Figure 10, the share of students studying engineering, manufacturing, or construction-related disciplines is miniscule, except in India (where it is comparable with that found in Southeast Asia). This is consistent with the fact that the share of manufacturing in South Asia's output has not grown, and remains well below that for Southeast Asia.

Second, despite the fact that half or more than half of the workforce is in agriculture, the share of students studying agriculture as a discipline is tiny, and even smaller than for the engineering category. Third, the share of students enrolled in humanities and arts courses is very high, except for India. Fourth, although the needs of the education and health sectors are huge, the share of students in these disciplines is also quite small. Finally, the disciplines that account for the largest share of students are social science, business, and law-a finding which is consistent with the fact that the share of services in total output and employment is surprisingly high for South Asian countries.

15 ADB (2012d) notes that the top-tier universities are approaching international standards, but the standard of the second- and third-tier universities necessitates further improvement. The lower tiers need to focus on building partnerships with industry for this purpose, with appointment of representatives of local industry on their career advisory boards. 


\section{Figure 10: Distribution of Tertiary Students by Program (\% of total)}

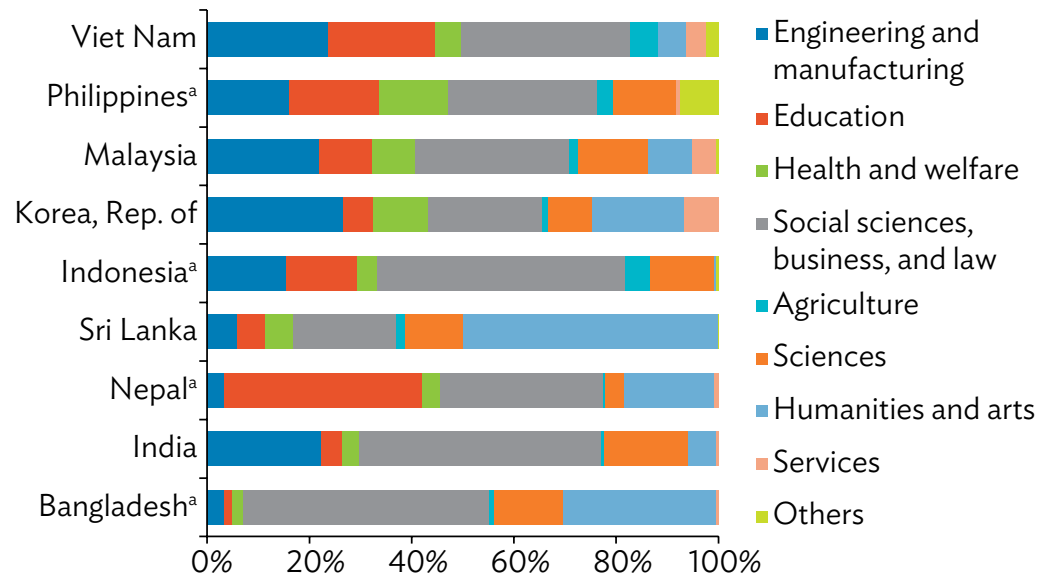

Notes: Unless otherwise specified, figures are as of 2012. *denotes that figures are estimates as of 2011 and 2004.

Source: United Nations Educational, Scientific and Cultural Organization Institute of Statistics.

\section{Box 5: Higher Education and Employability in East Asia and Southeast Asia}

The investments in higher education have paid off in Southeast Asia. Aside from having generally higher levels of education, the employability of graduates in Southeast Asia is also much higher. What is striking about Southeast Asian countries is the distribution at tertiary level by different disciplines. In Southeast Asia, there has been a focus on industrial policy and moving up the value chain in manufactured products. Correspondingly, a very significant proportion of students are in engineering, manufacturing, and construction programs $(15.5 \%$ in the Philippines, 16\% in Indonesia, 23.6\% in Viet Nam, 22\% in Malaysia, and 26.7\% in the Republic of Korea). The sciences also have a significant share of total students. The humanities and arts have a very small proportion of students in Southeast Asia.

The composition of the tertiary students by discipline has implications for the transition to the workplace (ADB 2012b). The salaried positions in the workforce achieved for receiving higher education are higher for workers with graduate degrees. But the situation is more complex when the difference is compared between university and higher technical and vocational education and training (TVET) graduates. University graduates in Indonesia receive higher occupation premiums than higher TVET graduates. But premiums for service, sales, and production workers are slightly higher in the Philippines. In Indonesia, about half of those with higher TVET qualifications are in professional occupations, and about one-third of university degree holders have jobs in the same occupations. But, importantly, a third of university degree holders are in clerical jobs, and less than a fifth of higher TVET holders are in clerical jobs. In any case, in both countries, earnings increase with greater occupational skills.

Source: ADB 2012b. 
What is notable about India is that technical education below graduate level, as well as at the graduate level and above, significantly raises the probability of getting a regular salary job than if one is a graduate with only general academic education. ${ }^{16}$ The good news is that the share in the workforce of those with any tertiary-level education rose from $7.3 \%$ in 2004-2005 to 10.3\% in 2011-2012 (Mehrotra 2015).

Both the labor market and tertiary education outcomes for men and women are rather different in India. It is well known that the labor force participation rate of women in India is well below that for men and, in fact, is one of the lowest in the world. Even more worrying is the fact that it has been declining. While there were 351 million men in the total workforce of 485 million in 2012, there were only 134 million women in the workforce. Nearly half of the women in the workforce are illiterate, but less than one-third of men in the workforce are illiterate.

If women acquire education up to the graduate level, whether it is general or academic or technical education, there is a high likelihood they will get regular employment. In fact, the probability of their getting regular employment is slightly greater with graduate education if they are women rather than if they were men.

Mehrotra (2015) analyzed the sectoral distribution of the workforce by level of education, both with general as well as technical education. The information is analyzed for the entire workforce by level of education: (i) illiterate, (ii) general education up to secondary level, (iii) general education up to higher secondary level, and finally (iv) graduate and above general education. The remaining two of the six categories analyzed are for technical education, below graduate, and then graduate and above level. As one would expect, twothirds of all illiterate workers are in agriculture. It is also noted that construction employees are a significant share of all illiterate workers.

Two-thirds of those who have graduate-level education enter services sector employment. This is more than 7 times as many as those graduates who enter manufacturing sector employment. It is well known that services account for $25 \%$ of total employment in the Indian economy, while manufacturing accounts for only $11 \%$. In fact, services account for the majority of those who have technical education as well. Half of those with below graduate technical education are employed in the services sector. That share rises to $80 \%$ for those with technical education of graduate level. In other words, the services sector accounts for the majority of those with some tertiary-level education, including those with technical education. On the ground, one example of this is reflected in the following fact: that elite Indian institutes of technology (better known as IITs, of which there are 14) graduate engineers more often than not end up in finance and other services. Manufacturing and nonmanufacturing employment accounts for less than one-third of all technical education graduates who have employment.

${ }_{16}$ The rate of unemployment of those graduates with general academic education is only slightly lower at 7.3\% than for those with technical education below or at graduate level (8.8\%). 


\section{National Education Policies and Institutions}

As countries in South Asia pursue various educational reforms to expand school access, public investments were mostly directed toward this end, especially at the primary and secondary levels, and have indeed resulted in higher enrollment rates (Dundar et al. 2015). For instance, to improve enrollments, primary school completion, and measurement of student learning, Bangladesh launched the Third Primary Education Development Program in 2011 as part of its National Education Policy (2010). Bangladesh has also pursued a series of interventions toward improving access to and quality of secondary education since 2005 (e.g., Teaching Quality Improvement in Secondary Education Project, Secondary Education Quality and Access Enhancement Project, and Higher Secondary Female Stipend Project [Phase-4 2009]).

In India, a series of universal education programs - the 2001 Sarva Shiksha Abhiyan (SSA or Education for All) and 2009 Rashtriya Madhyamik Shiksha Abhiyan (RMSA or Program for Universalization of Secondary Education) - were pursued by the central government to achieve universal enrollment and retention at the primary level by 2010 and at the lower secondary level by 2018. A legislation mandating free and compulsory education for all children aged 6-14, as well as the minimum input requirements (but not learning outcomes), was enacted in 2009 (i.e., Right to Education Act).

In the same year, Nepal launched its School Sector Reform Program to improve access to and quality of primary education, especially for children in marginalized groups. Since the early 1990s, Nepal has implemented a series of national educational programs for access and quality improvement (e.g., Basic Primary Education Projects [I 1992-1998 and II 1999-2004], Community School Support Program [2003-2008], Secondary Education Support Program [2003-2009], Education for All Program [2004-2009], Education and Sector Development Framework and Program [2006-2010]).

A comparison of the rates of public and private investments on education in Table 9 and Figure 11 indicates that South Asian countries are generally investing less than their counterparts in East Asia and Southeast Asia. ${ }^{17}$ In East Asia, the rapid educational expansion observed in the past decade was largely due to high economic growth, low demographic burden, and more equal income distribution, in addition to government policies in the education sector. According to Lee (2001), the four key education policies that contributed largely to the rapid quantitative and qualitative educational improvements in the region include school entry age, high private funding for post-basic education, efficiency of resource, and technical and vocational education and training.

Furthermore, while there is an overall decline in public investment rates in South Asian economies in recent years from rates in 2000-2009, the rates have increased in many of their counterparts. From 2000 to 2009, the share of education in total government expenditure declined by at least 1.5 percentage points in Nepal and as much as 5 percentage points in India. Except in Nepal, public education expenditure-to-GDP ratio shows a similarly declining trend in the last decade across South Asian economies. In India,

\footnotetext{
17 Except for India, very little data on public and private spending on education is available in South Asia.
} 
Figure 11: Expenditure on Tertiary Education by Source (\% of total in 2007)

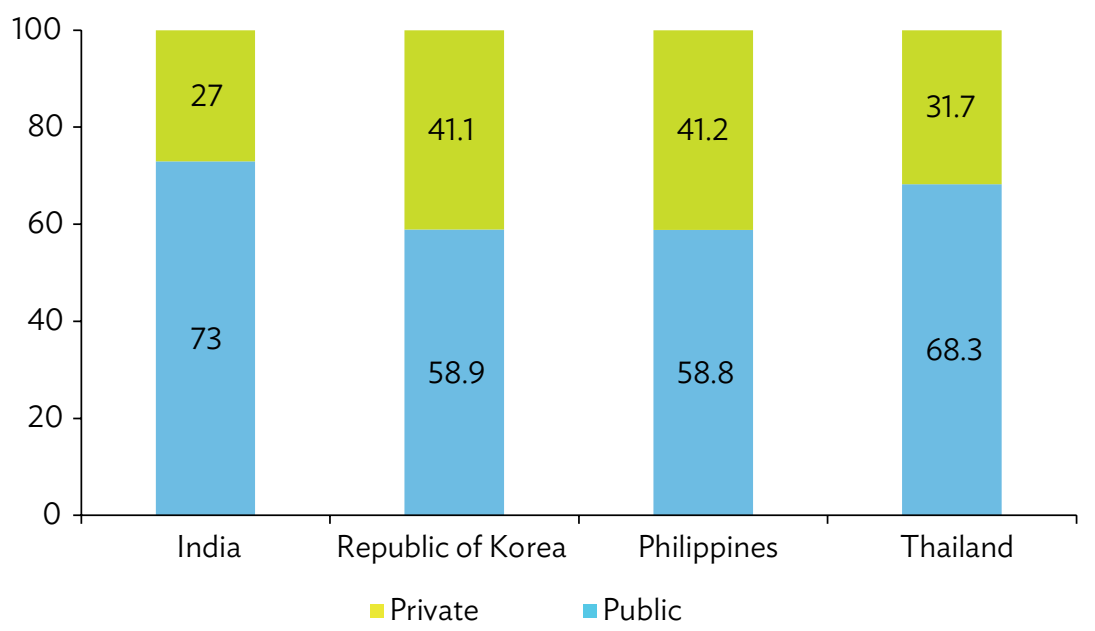

Source: United Nations Educational, Scientific and Cultural Organization Global Education Digest.

private education expenditure-to-GDP ratio increased from 0.2\% in 2000 to 1.3\% in 2004. This somehow offsets the decline in public education expenditure-to-GDP ratio.

In addition, the phenomenon that students receive private tutoring becomes common in the region. In Bangladesh, three in every 10 primary students (one in every two in urban areas) were privately tutored after school hours in 2005 (Bray 2009). Seven in every 10 households in West Bengal, India invest on tutoring of their primary school children. Similarly, in Sri Lanka, even if the number of private schools is very limited, three out of four primary school students are tutored privately (Dundar 2014).

Unlike in most South Asian economies, the expansion of private education institutions has been legally restricted in Sri Lanka since 1961 (Glewwe and Kremer 2006). In contrast, Bangladesh, India, and Nepal are increasingly relying on private sector expansion to support the growing demand for education, especially in the later part of the decade 2000-2009. According to Dundar and others (2014), private enrollment rates at the primary and lower secondary levels doubled in Bangladesh and Nepal between 2004 and 2010 (Dundar et al. 2014). In India, where private enrollment rates were initially higher, the expansion was more modest (by around 10\%), bringing private enrollment rates to around $26 \%$ at the primary and lower secondary levels in 2010. They estimate that in South Asia (including Pakistan), around three in every 10 children aged 6-15 years and four in every 10 children aged 16-19 years receive education from private schools. While the private enrollment rate at the upper secondary level in the region is comparable with that in the Republic of Korea, it is much lower at the tertiary level (80\% in 2012). 
Table 9: Public Investment on Education

\begin{tabular}{|c|c|c|c|c|c|}
\hline Region and Country & 2000 & & Latest & & Change (2000-latest) \\
\hline \multicolumn{6}{|l|}{$\%$ of government expenditure } \\
\hline \multicolumn{6}{|l|}{ South Asia } \\
\hline Bangladesh & 18.4 & & 13.84 & d & $(4.56)$ \\
\hline India & 16.36 & & 11.33 & g & $(5.03)$ \\
\hline Nepal & 24.19 & c & 22.73 & e & $(1.46)$ \\
\hline Sri Lanka & 11.58 & a & 8.75 & $\mathrm{~g}$ & $(2.83)$ \\
\hline \multicolumn{6}{|l|}{ Other Asian countries } \\
\hline China, People's Republic of & 11.36 & $\mathrm{~b}$ & - & & - \\
\hline Indonesia & 11.18 & c & 18.09 & g & 6.91 \\
\hline Korea, Republic of & 21.61 & c & 24.98 & f & 3.37 \\
\hline Malaysia & 21.39 & & 20.89 & f & $(0.50)$ \\
\hline Philippines & 15.21 & & 13.21 & d & $(2.00)$ \\
\hline Singapore & 14.77 & & 21.02 & $\mathrm{~g}$ & 6.25 \\
\hline Thailand & 27.48 & & 31.5 & g & 4.02 \\
\hline Viet Nam & - & & 20.94 & e & - \\
\hline \multicolumn{6}{|l|}{$\%$ of GDP } \\
\hline \multicolumn{6}{|l|}{ South Asia } \\
\hline Bangladesh & 2.38 & & 2.23 & d & $(0.15)$ \\
\hline India & 4.25 & & 3.35 & $\mathrm{~g}$ & $(0.90)$ \\
\hline Nepal & 2.98 & & 4.72 & e & 1.74 \\
\hline Sri Lanka & 3.05 & a & 1.72 & g & (1.33) \\
\hline \multicolumn{6}{|l|}{ Other Asian countries } \\
\hline China, People's Republic of & 1.91 & b & - &. & - \\
\hline Indonesia & 2.46 & c & 3.56 & $\mathrm{~g}$ & 1.10 \\
\hline Korea, Republic of & 4.12 & c & 5.25 & $f$ & 1.13 \\
\hline Malaysia & 5.97 & & 5.94 & $f$ & $(0.03)$ \\
\hline Philippines & 3.27 & & 2.65 & d & $(0.62)$ \\
\hline Singapore & 3.38 & & 3.23 & g & $(0.15)$ \\
\hline Thailand & 5.41 & & 7.57 & g & 2.16 \\
\hline Viet Nam & - & & 6.29 & e & - \\
\hline
\end{tabular}

- = data not available, GDP = gross domestic product.

a Reference year is 1998.

${ }^{b}$ Reference year is 1999.

c Reference year is 2001 .

d Reference year is 2009.

e Reference year is 2010.

${ }^{f}$ Reference year is 2011.

g Reference year is 2012.

Source: World Bank. 2014. World Development Indicators Online. http://databank.worldbank.org (accessed 24 December 2014). 
This is also reflected by the low private investment rates on tertiary education in the region (Figure 11). For example, while the private expenditure-to-GDP ratios on primary and secondary education in India are comparable with that in the Republic of Korea or the Philippines, it is strikingly very low at the tertiary level (Figure 12). The large contribution of private spending to educational expenditure, especially at the post-primary and tertiary levels, is a unique feature shared by East Asian economies in terms of education financing. East Asia relies heavily on the private sector to satisfy the demands for higher education (Lee 2001). The limited government resources available for education are largely directed to the development of primary education in most countries in East Asia, especially during their development period. Recent evidence on private rates of return on education support this (Box 6).

\section{Box 6: Rates of Return to Education}

Contrary to the results of earlier studies, recent studies suggest that the pattern in rates of return to education by education is rather changing. New evidence suggests that tertiary education, rather than primary education, has greater returns in the labor markets. Using the Living Standard and Measurement Study surveys conducted across 25 developing countries between 1985 and 2012, estimates of the standard Mincerian wage equations by Peet et al. (2015) demonstrate higher returns to tertiary education. They also found that return to education is higher for individuals residing in urban areas of developing countries than those residing in rural areas.

Sources: Psacharopoulos and Patrinos 2004; Peet et al. 2015; Colclough et al. 2009.

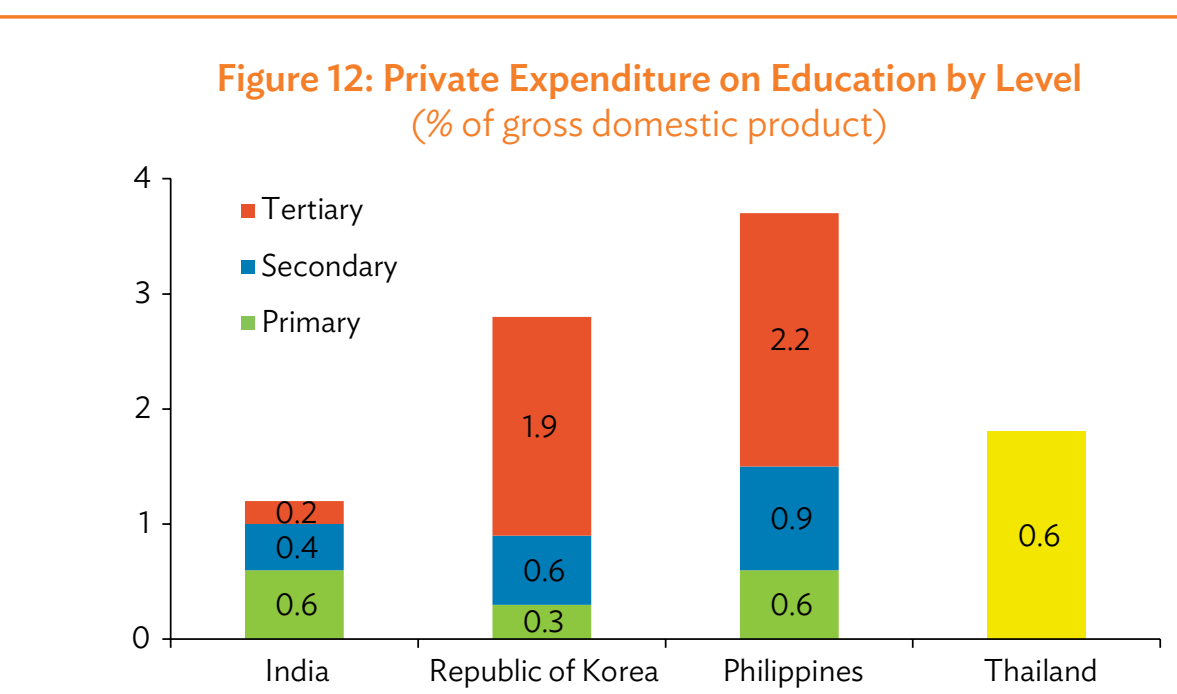

Note: Detailed breakdown of Thailand's private expenditure is unavailable.

Source: United Nations Educational, Scientific and Cultural Organization Global Education Digest (various years). 
Estimates on private rate of return do not seem to support the relative rates of private investment in India. Agrawal (2012) found that private returns increase with the level of education in India. Specifically, for every additional year of schooling, wage increases by over $5 \%$ at the primary level, over $6 \%$ at the middle level, over $11 \%$ at the secondary level, over $12 \%$ at the higher secondary, and almost $16 \%$ at the graduate level. The increasing returns to education suggest that, if given the opportunity, individuals have an incentive to achieve higher levels of schooling. However, as discussed earlier, many students fail to complete primary and secondary levels of education.

Agrawal suggests that the increasing private rates of educational returns can be attributed to two related factors: (i) technological advancement and industrial structure change, and (ii) the quality of schooling in India. The former suggests an increasing demand for skilled workers, while the latter implies the unavailability of these workers. Global firms and foreign enterprises, including call centers, which provide significant higher salaries than small-sized, domestic firms usually hire graduates from the good colleges and universities in India.

Rural-urban disparities in returns, which can be attributed to disparities in the quality of education, are also considerable in India (Agrawal 2012). Except at the graduate level, returns are lower across all levels in rural areas than in urban areas. The information regarding other South Asian countries is quite limited mainly because of lack of representative data. Asadullah (2006) reported that return to education is higher in the urban area compared with the rural area of Bangladesh.

Such disparities have implications to the pervasive income inequalities in India. For instance, a study by Cain et al. (2009) has shown that increases in returns to education, especially among households that rely on income from education-intensive services and/or education-intensive occupations, led to increased levels of inequality in the Indian urban sector during the 1993-2004 period. 


\section{LABOR FORCE AND SKILLS}

\section{Highlights}

- South Asia needs to keep up with the evolving skills requirement of the economic structural transformation process, as well as the rapidly growing youth workforce, in the region.

- In preparing new entrants to the workforce, both capacity and quality constraints are needed to be addressed by the public and private sectors in the region.

- Systemic problems are also needed to be addressed to enable skills development institutions to upgrade the quality of skills they produce.

Most South Asian economies, which have experienced more rapid economic growth in the past decade compared with earlier decades, are now undergoing a structural transformation process. Along with this usually comes an evolving skills requirement that the workforce has to meet in order to adequately support the economy and the transformation process. As these economies undergo early stages of structural transformation, they are now experiencing shortages of skilled personnel.

As shown in section II (Figure 2), unlike in most economies in East Asia and Southeast Asia, half of employment in most of South Asia remains in agriculture. Policy makers would like to see a greater shift in favor of nonagricultural output, as well as employment. However, the educational and skills development systems in these countries have little flexibility in response to the changing economy. The experience of other economies in East Asia and Southeast Asia, which have moved further along in the development process, in developing technical and vocational education and training (TVET) led by the government and firms provides useful lessons for South Asia.

\section{A. Evolution of Employment Structure and Skill Requirements}

One of the central lessons that can be learned from the economies in East Asia and Southeast Asia in terms of creating decent and productive employment is the deliberate use of well-designed government policies that target sectors with promising potential for both output and employment growth. Although defining the priority sectors for future development of skills remains a challenge, the presence of economic planning helps ensure the match between supply and demand of skills (OECD 2009). The coexistence of economic and human resources policies, along with prior investment on education and 
skills development, played a major role in the rapid structural transformation of East Asian and Southeast Asian economies as earlier discussed in section II (Figure 2).

Although the share of the industry sector in total employment in India, Bangladesh, and Nepal has improved since the 1990s, it has not managed to match the levels reached by other more developed economies in Asia at the peak of their industrialization (Table 10). This is mainly because economic reforms began in these South Asian economies later than in more developed East Asian and Southeast Asian economies. The reform started in India only in 1991. At that time, the proxy for industrial policy was perceived by policy makers to mean the dismantling of the license-permit raj, which was accompanied by deregulation, reduction in trade barriers, and domestic liberalization. However, it is not until 2 decades later that India has attempted to develop an industrial policy, which finds expression in the 12th Five Year Plan (which may well be the last 5-year plan in India, given the practical dismantling of the Planning Commission of India by the new government elected in May 2014). ${ }^{18}$

Table 10: Employment Share of Industry Sector

\begin{tabular}{|l|r|r|r|}
\hline Region and Country & 1980 & 1990 & 2012 \\
\hline South Asia & & & \\
\hline Bangladesh & 11.0 & 13.0 & 14.5 \\
\hline India & 15.7 & 15.7 & 24.7 \\
\hline Nepal & 2.7 & 2.7 & 13.4 \\
\hline Sri Lanka & 18.6 & 20.6 & 17.7 \\
\hline Other Asian countries & & & \\
\hline China, People's Republic of & 18.2 & 21.4 & 29.5 \\
\hline Indonesia & 13.1 & 13.7 & 21.7 \\
\hline Korea, Republic of & 29.0 & 35.4 & 17.0 \\
\hline Malaysia & 24.1 & 27.5 & 28.4 \\
\hline Philippines & 15.4 & 15.0 & 15.4 \\
\hline Singapore & 35.7 & 35.2 & 21.8 \\
\hline Thailand & 10.3 & 14.0 & 20.9 \\
\hline Viet Nam & 10.6 & 10.6 & 21.1 \\
\hline
\end{tabular}

Note: Figures are latest data as of 1980, 1990, and 2012.

Source: International Labour Organization's Key Indicators of the Labour Market database as compiled by World Bank (2015).

Nonetheless, policies are not the sole reason behind the success of industrial development in Southeast Asia. These economies have effectively utilized their abundant factor of production-labor-to initially produce simple manufactures and later progressed to more sophisticated products for the international market as shown by the rapid increase in their export-to-GDP ratios. These ratios grew even between the Asian economic crisis of 1997-

18 The new government in India does have a focus on manufacturing growth reflected in the slogan "Make in India" and "Skill India". 
1998 and the global economic crisis of 2008-2009, compared with South Asia. Equally importantly, Southeast Asian economies have successfully managed the rapid expansion of primary and then secondary enrollment and completion rates as discussed in Section II. Through time, a growing proportion of the labor force is increasingly achieving higher levels of education.

Another common dimension in the evolution of employment structure that has important implications for the preparation of human resources in both regions is the overall transition from manufacturing to services-based economies in Southeast Asia. This transition requires the development of a workforce that has more advanced skills. However, there has been premature growth in demand in the services sector in South Asia, without sufficient growth in the manufacturing sector. For low-income developing countries, deindustrialization and high dependence on the services industry could reduce productivity and output growth of the country (Rodrik 2014). A country with a services-led development tends to have a smaller market, compared with those that are driven by growth in the manufacturing sector. The services-oriented development may also hamper technological improvement, especially when the economy has a low level of human capital (Rodrik 2014).

In addition, most of the growth in both manufacturing and services employment in South Asia occurs in small enterprises. Mostly unorganized and informal, these enterprises usually employ fewer than 10 workers and have limited capacity to offer trainings, whether preservice or in-service.

Both South and Southeast Asia economies have high shares of employment in the informal sector. In South Asia, majority of the workforce is in the informal sector (Mehrotra and Biggeri 2007). The classic case is India with $78 \%$ of its workforce in small enterprises employing fewer than 10 workers in 2011-2012 (Mehrotra et al. 2013). This figure is lower for Sri Lanka (around $62 \%$ of nonagriculture sector employment in 2010), but not in the smaller South Asian economies, which have a larger proportion of workers in the informal sector.

In Southeast Asia, despite sustaining higher levels of economic growth and reaching the middle-income status much earlier than India, the informal sector remains large. For example, in 2010, the share of informal employment in nonagricultural employment was around $61.6 \%$ in Indonesia, 68.2\% in Viet Nam, and 70.1\% in the Philippines (World Bank Group 2013). With demographic change and urbanization, the expansion of the informal sector is not slowing down to levels lower than that in South Asia (Mehrotra and Biggeri 2007). Although agricultural employment is declining, the number of own-account workers is expected to increase (Fernandez-Martinez and Powell 2009). The informal sector may accounted to as much as $60 \%$ of the total employment of the Association of Southeast Asian Nations (ASEAN) in 2015 due to the rapid growth of urban populations in the region and the ongoing expansion of their service sectors. Unlike the PRC or the Republic of Korea, most ASEAN countries (except Singapore and Malaysia) have dual labor markets and skill requirements as in South Asia. Countries with greater urbanization, such as Cambodia, Indonesia, the Lao People's Democratic Republic, and Viet Nam, are likely to face greater social and economic challenges (International Labour Organization [ILO] 2007).

Although dual economies call for greater local flexibility, education and training institutions in South Asia, and to a lesser extent Southeast Asia, are mainly targeting the modern, 
formal sector. In both Southeast Asia and South Asia, the existing formal training apparatus is usually inaccessible to the poor. As a result, poor workers have little access to skills development. As economies become more advanced, governments in the region should give attention to strategies that facilitate the transition of entrepreneurs and self-employed from the informal economy into the formal economy. Skills development systems must not only focus on the skill demands of dynamic sectors, but also address the need for basic skills that most workers lack (ILO 2006, Palmer 2007). Governments should also focus their efforts on skills development and productivity of organizations that operate in the formal sector, by encouraging the private sector to take responsibility to a much greater extent than at present, especially those that are involved in higher value-added production and could support in-firm training.

Small and medium-sized enterprises (SMEs) outnumber large enterprises in South Asia and Southeast Asia, not only in terms of their share in the total number of establishments, but also in their share of the labor force they employ (OECD 2009). ${ }^{19}$ In India, over $90 \%$ of establishments operate with fewer than five workers and over $60 \%$ of the employees in the manufacturing sector are in SMEs (ADB 2009). There is often a "missing middle" hollowness in the industrial structure where there is a lower-than-average presence of medium-sized firms. In other smaller countries in South Asia, almost all firms are small. Over a decade ago, in Southeast Asia, the shares of SMEs to total number of firms were 98\% in Indonesia, $84 \%$ in Malaysia, 99\% in the Philippines, 91\% in Singapore, 96\% in Thailand, and $96 \%$ in Viet Nam (Asasen et al. 2003). During the same period, the shares of SMEs to employment were 88\% in Indonesia, 39\% in Malaysia, 66\% in the Philippines, 52\% in Singapore, $76 \%$ in Thailand, and 85\% in Viet Nam (Asasen et al. 2003).

However, it is very difficult to assess the state of skills in SMEs in both regions due to lack of consistent data on SMEs. Entrepreneurship development and managing skills, especially for SMEs, are needed across all industries. Training for workers in the informal economy on basic and generic skills (such as literacy and numeracy) as well as entrepreneurial skills (such as risk management, opportunity analysis) facilitates the transition from self-employment in the informal economy to microenterprise development in the formal economy. Across the region, there is little emphasis on building up local capabilities for training in entrepreneurship development in Southeast Asia too, not just in South Asia. In particular, financial capabilities of SMEs are among the greatest challenges for this sector to survive through the economic crisis. Therefore, it is a key skill to be developed.

Labor force participation rates (LFPRs) among females vary significantly across Southeast Asia and South Asia. The rates are much lower in South Asia, except in Nepal-a mountainous country where the majority of men migrate to neighboring India for work, leaving the women to look after the land or generate other means of livelihood (the same in Bhutan). The rates in Bangladesh and Sri Lanka are comparable with (though slightly higher than) those for India.

19 The important limitations to SME development are the lack of agreement on the definition of SMEs and the lack of data and information on the SME sector, which are not up-to-date across the region (hence the age of the data as reported above), despite the intrinsic importance of SMEs to Asian economies and a renewed policy focus on them in recent years. 
Table 11: Female Labor Force Participation Rates

(\% of female labor force)

\begin{tabular}{|l|c|c|}
\hline Country & $2005-2009$ & $2010-2013$ \\
\hline South Asia & & $36.0^{\mathrm{b}}$ \\
\hline Bangladesh & $18.0^{\mathrm{a}}$ & 77.5 \\
\hline Nepal & - & 25.8 \\
\hline India & 37.3 & 35.6 \\
\hline Sri Lanka & 32.8 & \\
\hline Other Asian countries & & 67.5 \\
\hline China, People's Rep. of & 66.4 & 50.3 \\
\hline Indonesia & 51.0 & 52.4 \\
\hline Malaysia & 46.4 & 50.2 \\
\hline Korea, Republic of & 49.2 & 49.9 \\
\hline Philippines & 49.5 & 73.2 \\
\hline Viet Nam & 72.3 & \\
\hline
\end{tabular}

- = data not available.

a Data for 2005.

${ }^{b}$ Data for 2010.

Source: International Labour Organization (2013) Key Indicators of Labor Market.

An important stylized fact in the labor economics literature about female LFPR is that, in a cross-section of countries, there is a $U$-shaped relationship between per capita income and female LFPR. That is, at very low levels of per capita income (e.g., Bangladesh, Nepal), female LFPR tends to be high, falling as per capita income rises (India). After crossing the middle-income country level, the female LFPR rises again. None of the South Asian countries may have reached that upward stage of the U-curve yet, except perhaps Sri Lanka. On the other hand, the Southeast Asian countries are in the upward part of the U-curve.

The implication for skills is that this evolution will force policy makers to become more proactive in South Asia to ensure that nonagriculture sectors (where women would prefer to work, as they get more educated) get the skilled labor that the sectors will demand. With greater urbanization and education, the young educated girls will also wish to move into modern industry as well as services, and the TVET system will need to respond accordingly.

Another demography that the policy makers in South Asia concerned with TVET will need to be worried about is the growing size of the labor force every year. Most South Asian countries are at the midpoint of their demographic dividend, and their labor force will continue to grow for another quarter century. Southeast Asian countries, on the other hand, are nearing the end of their demographic dividend (certainly the PRC and the Republic of Korea are at the tipping point), though the rest of the countries in Southeast Asia in this study would still have a growing labor force over the next decade. 
As shown in Table 12, youth and adult unemployment rates appear to be higher in Southeast Asia than in South Asia, which is a reflection more of a mismeasurement taking place in South Asian countries, given the higher degree of informality noted earlier. The scale of underemployment in South Asia is fairly well known and written about, and does not need elaboration here; hence, what appear to be lower rates of open unemployment in South Asia that we see in these tables should not leave policy makers complacent. If anything, the majority of workers in South Asia are too poor not to work, so that they take up such casual work as is available at low wages and low productivity, and appear to be working though would show up in the category of "working poor." In any case, such underemployed youth need to be skilled if they are already in the labor force in South Asia. Similarly, those entering the labor force should at least have access to TVET, so that they can get skilled before joining the labor force.

\section{Table 12: Youth and Adult Unemployment Rates}

(\%)

\begin{tabular}{|l|c|c|c|c|}
\hline \multirow{2}{*}{ Country } & \multicolumn{2}{|c|}{ Youth (15-24 Years Old) } & \multicolumn{2}{c|}{ Adult (24-64 Years Old) } \\
\cline { 2 - 5 } South Asia & $2001-2007$ & $2008-2014$ & $2001-2007$ & $2008-2014$ \\
\hline Bangladesh & & & & \\
\hline Nepal & 9.3 & 8.7 & 4.3 & 4.5 \\
\hline India & 3.0 & 3.5 & 1.9 & 2.2 \\
\hline Sri Lanka & 10.0 & 10.2 & - & - \\
\hline Other Asian countries & - & 15.7 & - & 4.4 \\
\hline Indonesia & & & & \\
\hline Malaysia & 25.1 & 31.3 & 9.4 & 9.4 \\
\hline Korea, Republic of & 10.9 & 10.4 & 3.2 & 3.1 \\
\hline Philippines & 8.8 & 9.3 & 3.8 & 3.2 \\
\hline Viet Nam & 17.4 & 16.2 & 7.6 & 7.7 \\
\hline
\end{tabular}

$-=$ data not available.

Sources: Secretariat of the Pacific Community 2004; and the National Minimum Development Indicator Database - Secretariat of the Pacific Community website (http://www.spc.int/nmdi/). World Development Report 2013 on Jobs Statistical Tables, World Bank Group.

\section{B. Technical and Vocational Education and Training Systems in South Asia}

Although TVET systems of the countries in South Asia vary in terms of characteristics, they share common weaknesses and skills development challenges, particularly the employability of new graduates.

India

India's demographic dividend, which started to accrue in the early 1980s, is now at the midpoint of this dividend, and is seen to last only until around 2040. Since 2005, there have been about 5 million-7 million young entrants to India's workforce every year. At the same time, 7.5 million nonagricultural jobs are added each year. As noted earlier, although the organized employment has been growing rapidly, most of the additional jobs are created 


\section{Box 7: Technical and Vocational Education and Training Systems in East Asia and Southeast Asia}

While many issues and challenges are country-specific, there are some that are common across Southeast Asian countries. Here are the common issues before going to each country. One common challenge to most countries in East Asia and Southeast Asia, which also present opportunities, is the migration and mobility of skills, both within and across countries. This implies the need for increased transferability and recognition of skills.

As in most developing countries in Asia, training unskilled workers from rural areas to become production workers is a common challenge in Southeast Asia. In the more industrialized parts of Asia, such as the People's Republic of China, Japan, the Republic of Korea, Malaysia, and Singapore, demand for medium-skilled workers (e.g., craft/trades and operator/assembler) has declined quickly as the demand for high-skilled workers has increased. Although the shares of elementary occupations have increased in all countries, the decline in production jobs was not entirely matched by the growth in high-skilled jobs. Mongolia and the Philippines have experienced a reduction of craft/trades and production jobs and an increase of elementary occupations. The countries are faced with upskilling demands for a wide range of their unskilled workforce.

Another problem faced by many Asian countries is the increasing knowledge intensity and skills development in the workplace. Asian countries commonly have a large share of unskilled and semiskilled workers, more so in South Asia than in Southeast Asia. To move to higher value-added production and toward a sustained growth path, workplace training is becoming a key. Skill shortages are becoming an impediment for their sustained growth, and countries are seeking to upskill their labor force through workplace training. A common problem in promoting workplace training is the low level of skill investment of industries, especially in South Asia (though much less so in Southeast Asia). To overcome this problem, several countries have introduced incentives, including tax exemptions for training costs in Southeast Asia, to promote workplace training.

East Asian and Southeast Asian countries are at different levels of development of their technical and vocational education and training (TVET) systems. The People's Republic of China, the Republic of Korea, and Malaysia have fairly evolved systems with reasonably good articulation among their various constituent parts, on the one hand, and between the TVET system and industrial policy for economic growth on the other. The other TVET systems discussed in this section (Indonesia, the Philippines, and Viet Nam) are less effective in both their internal articulation as well as their articulation with the needs of their economy. Annex 1 provides a detailed analysis of TVET systems in selected countries in East Asia and Southeast Asia.

Source: Christina-Martinez and Powell 2012.

in the unorganized segments of industry and services sectors (i.e., those employing fewer than 10 workers) (Mehrotra et al. 2014).

After the biases inherent in India's import-substituting industrialization regime were eliminated during the economic reforms of 1991, there ceased to be any industrial policy worth the name. The entire education system was biased for 40 years toward higher-level education to the detriment of overall school education, and a focus on technical education at tertiary level to the detriment of vocational education in school or adequate expansion of even polytechnics. There occurred complete neglect for 4 decades until 1990 of school education, including vocational education in schools as well as preemployment pre-tertiary vocational training, on the one hand; and too much emphasis on elite tertiary technical institutions (in science, engineering and management, medicine) to the detriment of the 
larger higher education system's growth with quality. Since the early 1990s, there has been appropriate focus on universalizing at least 8 years of general academic education and, since the middle of 2000-2009, a newfound focus on skills development, but not enough reform and even quantitative growth of the TVET system.

Growing by almost $8 \%$ (at factor cost) the 10th and 11th plan period (2002-2007 and 2007-2012), India is likely to surpass the PRC's GDP growth rate by 2016 (Planning Commission 2013). It is inevitable for a fast-growing economy like India to experience skill shortages, especially among semiskilled and highly skilled workers. As of 2010 , only $2 \%$ of India's workforce had acquired any form of formal vocational training, and an additional $8 \%$ of the workforce had acquired vocational training informally on the job. In other words, only $10 \%$ of the workforce and $20 \%$ of the nonagricultural workforce had acquired vocational training of any sort, formal or informal kind (Mehrotra et al. 2014). Mehrotra et al. (2014) estimated that, between 2012 and 2022, India will have almost 300 million additional workers to be skilled. Of this number, some 100 million youth should complete at least up to the secondary level (i.e., grade 10). In addition, the remaining 200 million consist not only of new entrants to the labor force, but also those who have acquired training informally on the job. They will need to receive some formal vocational training, and also certification of their already achieved vocational skills ( 55 million). Furthermore, it is estimated that at least 136 million youthful new entrants to the labor force will need to be provided vocational training on a formal basis. The task clearly needs an expanded school education system and additional vocational training providers, as well as for India's companies to undertake more vocational training. The task is stupendous, if not monumental. ${ }^{20}$

India's neglect of elementary education in the first 4 decades after independence (i.e., between 1950 and 1990) had led to millions joining the labor force without even completing primary education. As a result, in 2009-2010, the share of the labor force (in the $15-59$ age group) that was not even literate was $29.1 \%$, or 125.7 million of the 431.2 million labor force. In addition, another $23.7 \%$ of the labor force had either primary or below primary level of education (102.4 million) (Mehrotra et al. 2014).

Although 90\% of employment opportunities in India require vocational skills (Okada 2012), skill formation among young people who constitute the largest and rapidly growing segment of the demographic structure is low. About $17.6 \%$ of the labor force (or 76.1 million) had only acquired up to grade 8, and as of 2009-2010, seven in every 10 workers in India did not complete secondary education. In addition, the vocational education system in the higher secondary level had remained stunted, with only $3 \%$ of those who were in higher secondary education (11th and 12th) in the vocational education stream, compared with $44 \%$ of youth at the secondary level of education in the PRC who were in the vocational education stream (Kuczera and Field 2010).

\footnotetext{
20 The Government of India's National Skill Policy (2009), now under revision (with a new draft available for consultation), is working with an estimate of those requiring skills development of an even larger number: 500 million. This 500 million number (arrived at on the suggestion of an Indian American, the late Professor C.K. Prahlad, a management guru) is a gross overestimate, since it is highly unlikely that the size of the labor force in 2022 will exceed 570 million (see Mehrotra et al. 2013 for a detailed explanation). It is illogical to suggest that 500 million of the 570 million would need, or could feasibly be provided, general and vocational education and training. Moreover, the 500 million number seems to assume that all those farmers in agriculture would need training, or they move out of agriculture to nonagricultural occupations (which is highly unlikely given the rate of absorption of workers in industry and services). In any case, there is no definition of "skills" that underlies the 500 million figure.
} 
As shown in Figure 13, student participation in formal technical and/or vocational courses at the secondary level in India is very low compared with the PRC, other developed countries in Asia, and the United Kingdom. Every year, about 6 million-7 million young people enter the labor market. However, with only 5 million vocational training seats available in the country (Mehrotra 2014), most of these young people remain unskilled and, often, they find work in the informal sector (Okada 2012). In addition, aside from being low, the level of skill formation varies across states in India. For instance, while 15.5\% of youth aged 15-24 received formal skills training in Kerala, only less than $1 \%$ of those in Bihar were formally trained.

\section{Figure 13: Proportion of Secondary Students Enrolled in Technical and/or Vocational Education Programs}

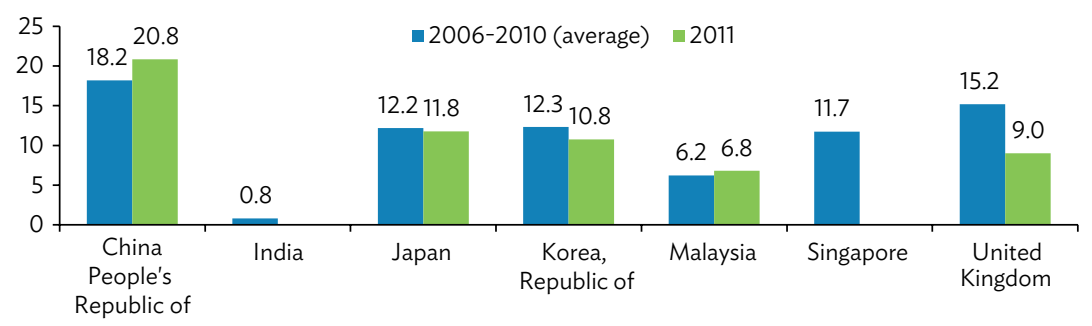

Source: World Bank (2014).

As of 2010 , only around 43 million or less than $10 \%$ of the labor force in India had some vocational training in 2009-2010, and only less than $2 \%$ of the total labor force in India had formal training (Government of India 2012a). As shown in Figure 14, the proportion of males (ages 15-59) who are either receiving or have received any vocational training is twice as much as females. Some $33 \%$ of workers with vocational training are in the services sector, $31 \%$ are in manufacturing, $27 \%$ are in agriculture, and the rest are in nonmanufacturing and allied activities (Government of India 2012a).

As noted previously, India's female LFPR is one of the lowest in the world (as India is probably at the bottom of the $U$-shape), though it should begin to rise again. Providing jobs keep growing in the nonagriculture sector and education levels keep rising, as they have been. However, skill levels for girls must also rise for girls to be wage-work or selfemployment ready in industry and services. Youth open unemployment rate was over $10 \%$ in 2010 (Table 12), but more worrying is the fact that as much as half of young women aged 15-24 are neither in school nor at work. A slowly growing share of these women, as they get educated up to secondary level, are likely to join the labor force, looking for modern, urban employment-a phenomenon that occurred in the PRC and most of Southeast Asia. They will have to be skilled to be prepared to join new nonagricultural work in occupations that their mothers did not engage in. Enrollment at secondary and upper secondary levels has been rising rapidly, especially but not only for girls. 


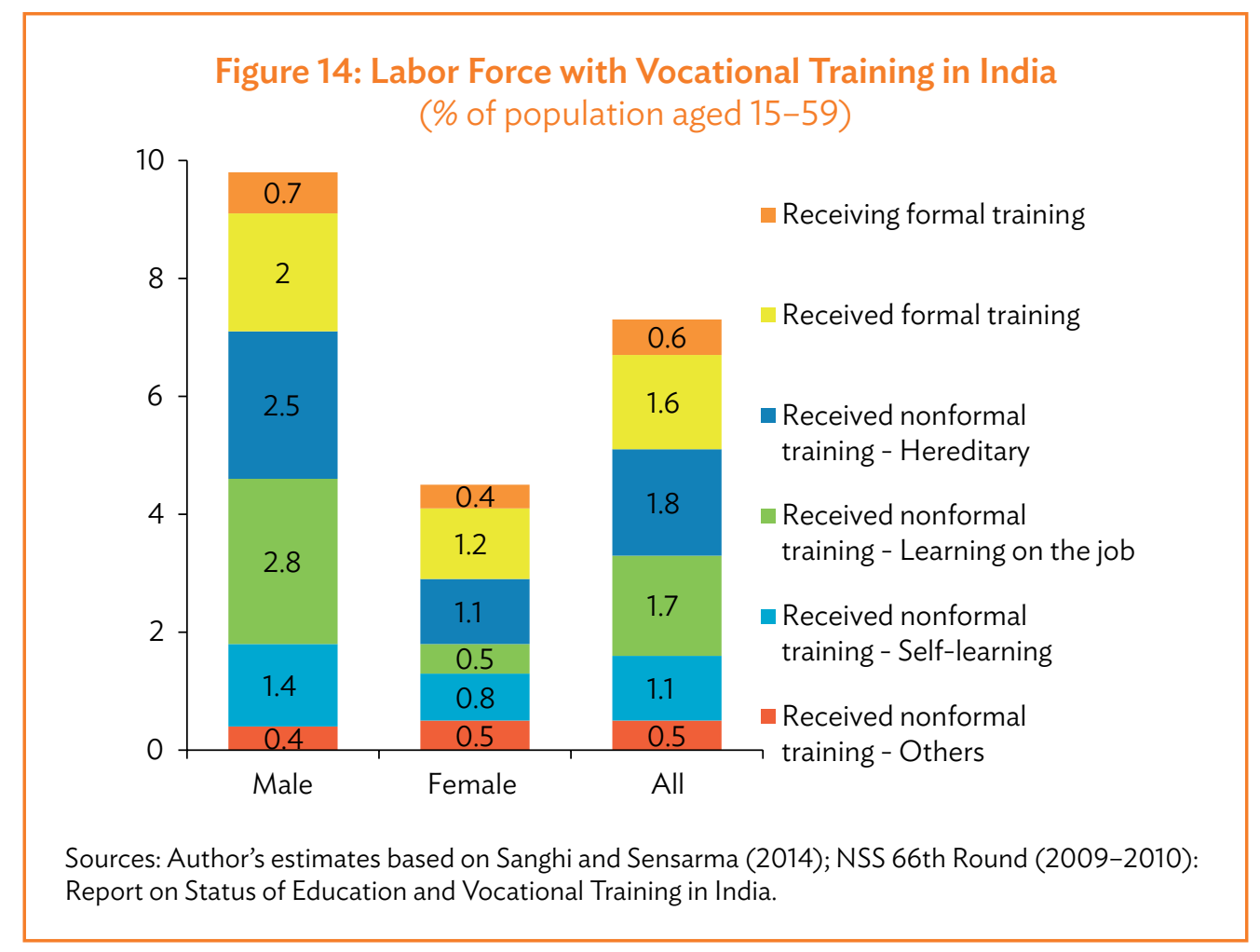

Barely $2 \%$ of the total workforce in India has formally acquired TVET skills. ${ }^{21}$ Sponsored by various agencies, TVET programs in India are identified as too fragmented and ineffective (Panth 2013). Programs, which have varying duration, target groups, entry qualifications, testing and certification, and curriculum, overlap and have little unified recognition of qualifications and equivalence (Okada 2012). Industrial training institutes in India have largely been supply-driven rather than demand-driven (Okada 2012). They lack the flexibility to respond to specific local skill demands because they follow a highly standardized curriculum. They are also outdated in terms of facilities and equipment.

As in many other countries, the governance of India's vocational training system has been complex. Until recently, the Ministry of Human Resource Development, which is responsible for formal education, was only slightly involved in TVET activities. In addition to the Directorate General of Employment and Training, more than 17 ministries or departments of the Government of India, along with their related agencies, provide or sponsor TVET programs.

The Government of India has recently pursued drastic measures to reform its training policy, intensifying its efforts to increase the number of skilled workers. These include forging partnerships with leading firms in the industry (e.g., Toyota, Tata Motors, Suzuki) to offer training courses to suit specific skills requirements of the firms. It will be interesting to assess the effectiveness of this reform in improving access to, and responding to the demand for vocational training.

${ }_{21}$ For a more detailed critique of the Indian TVET system, see Mehrotra (2014). 
There are various reasons behind the narrow coverage of TVET system in India. First, vocational education has historically been offered only at the higher secondary level (classes 11 and 12). In the school system, the only possibility for a young person to acquire any vocational skills arises when the youth has achieved the age of 16, and enters the higher secondary level. In the PRC, children can opt for either the general academic or the vocational scheme after completing 9 years of compulsory academic education. In India, children do not have any opportunity to pursue vocational education until they have completed at least secondary schooling (classes 9 and 10) at general academic level. Not surprisingly, only 3\% of all youth of the relevant age group are in the vocational education stream (Kuczera and Field 2010). This is now beginning to change, thanks to the National Skills Qualification Framework, which became national policy from 2012 onward.

Second, the Ministry of Labour (MOL) runs industrial training institutes (ITIs) (nearly 2,000 ITIs in 2014) in the public sector. In addition, there are about 10,000 private ITIs that are supposedly regulated by the MOL. Children who have completed 8 years of education can enter in some vocational training courses in these ITIs, but most ITI courses require at least 10 years of general education. Given the still less-than-universal enrollment in upper primary level (83\% gross enrollment ratio for grades 6-8), the secondary enrollment is even lower, the narrow TVET coverage is understandable.

Third, since 2010 when the National Skill Development Corporation (NSDC) was created, over 1,000 private providers have emerged across the country, which are financed by the NSDC. ${ }^{22}$ In addition, there is a very large number of private vocational training providers (VTPs) which are unregulated and unrecognized by the government; it is impossible to estimate their number precisely because these are neither registered nor recognized by any government body and, hence, continue to mushroom in whichever sector might be seen by entrepreneurs as profitable. The NSDC-supported private VTPs, however, are not only registered but have to promise, when they receive funding from NSDC in the form of equity and loans, that they will ensure that $70 \%$ of their trainees will get placement. Thus, the NSDC has promoted, for the first time in India's TVET history, vocational training provision on a for-profit-based business model, but where the providers are registered, recognized, and are not fly-by-night operators, and could be held to account for nonperformance in terms of poor placement record of their trainees. The information technology (IT) sector in India has, for long, had this business model, and been very successful. The National Institute of Information Technology is a classic example, which has opened offices in many other countries as well. But, in other sectors, this business model has not taken off.

Finally, the fourth form of skills development is in-firm, provided in-house by medium-sized and large enterprises. The proportion of companies that were formally conducting in-firm training in India more than doubled between 2006 and 2014, from only 15.9\% to 35.9\%, but still less than half of the same figure in the PRC (80\%). Aside from being relatively low, training provision is mostly confined in the organized segment of the Indian industry, which accounts for only $22 \%$ of all employment in India.

22 The NSDC is one of the three bodies that came into existence as part of an effort to implement the National Skills Policy (2009). The first body is primarily advisory, the Prime Minister's Council on Skill Development; the second body has the role of coordinating the training activities of the 17 line ministries of the Government of India engaged in TVET, as well as coordinating with state governments and private bodies that are engaged in skills development functions; and the third is a public-private partnership (with $50 \%$ equity provided by the private chambers of commerce and industry, and $49 \%$ of equity by the Government of India), the NSDC, which is effectively the implementation arm of the national skill development strategy. 
Figure 15: Proportion of Companies Providing Formal In-Service Training

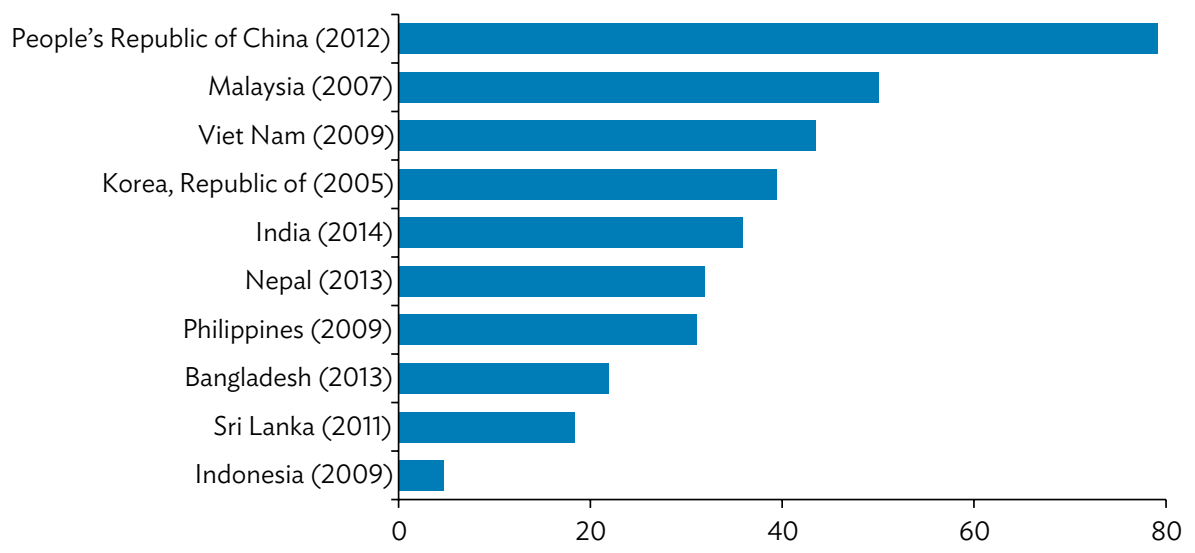

Source: World Bank (2015).

This in-firm training could be in one of the following three forms. First, the MOL has been promoting the engagement of apprentices by organized sector enterprises under the Apprenticeship Act 1962. This is intended mostly for those graduating from the MOL's ITIs, private or public. ${ }^{23}$ However, an ITI certificate is not a necessary prerequisite for becoming an apprentice under the MOL's scheme, the Apprenticeship Training Scheme. The second form that the apprenticeship takes is intended for those who have at least a post-higher secondary diploma or certificate, or a degree in one of the many engineering disciplines from polytechnics or engineering degree colleges, supervised and regulated by the Ministry of Human Resource Development of the Government of India. While the MOL promotes apprenticeships for 16-18-year olds who have graduated from their ITIs, the Ministry of Human Resource Development promotes apprenticeships for a slightly older age cohort, which has received a higher level of skills training than the ITI graduates. The third form of in-firm training is offered usually by private companies, which have nothing to do with either the apprenticeship scheme of the MOL or of the Ministry of Human Resource Development.

What distinguished the Southeast Asian countries' job-creation and skills-generation record (especially in the PRC, the Republic of Korea, and Malaysia) to match that is effective industrial policy focusing on meeting international demand for manufactures. While the 12th Five Year Plan of India in the industry chapter has articulated the need for an industrial policy, the skills or TVET preconditions for such an industrial policy also need further elaboration. ${ }^{24} \mathrm{~A}$ lesson from the PRC is that the sheer scale and size of their TVET system dwarf anything found in any South Asian country. For instance, India cannot match that scale without ensuring that India's 100,000 secondary/senior secondary schools have a vocational education stream. Currently, vocational education is offered mainly at the

23 This responsibility has been moved to the newly created Ministry of Skill Development since May 2015.

${ }^{24}$ Like the other South Asian countries, India too has a National Skills Policy 2009, which is being revised. 
senior secondary level in India (i.e., classes 11-12). Three years ago, the Ministry of Human Resource Development had approved a National Vocational Education Qualifications Framework (which was called the National Skills Qualifications Framework later), which mandated the inclusion of vocational education from class 9 . However, that has been introduced in only 1,000 or so secondary schools in 22 states so far.

Many children aged 15 (legal working age) drop out after completing only 8 years of basic education to enter the labor force. While half of all children completing 9 years of compulsory academic schooling in the PRC enter vocational schools at senior secondary level, in India, only 3\% of children at the senior secondary do so (Kuczera and Field 2010). Starting a vocational stream in every secondary school may help India to catch up with the PRC system.

\section{Bangladesh}

Despite the rapid progress in recent years, the gross enrollment ratios in Bangladesh remain lower than those in other South Asian countries, especially at the secondary level. Nonetheless, it has a rather large number of students in vocational programs at upper secondary school relative to other South Asian countries, but still lower than those in Southeast Asian countries. This is perhaps a reflection of the fact that children have access to vocational education at secondary level already (unlike in India where vocational education was not even an option at secondary level until recently, and was available only at upper secondary level).

The TVET system in Bangladesh consists of three parts: (i) a basic course of less than 360 hours; (ii) a vocational program at secondary school certificate level; higher secondary certificate in vocational of 2 years duration; and (iii) a 4-year diploma at polytechnics and mono technical institutions. Most of the children enrolled in vocational programs at secondary level are in private institutions and the number of private institution is also 10 times larger than that of public institutions at secondary level.

The management of TVET is in the hands of the Ministry of Education. Two separate bodies in the ministry manage the system: the Bangladesh Technical Education Board is responsible for quality control by means of examination, certification, and approval of private training providers. The Directorate of Technical Education is the body for administering government technical and vocational institutions and programs. At the national level, the policy-making body is the National Skills Development Council headed by the Prime Minister (ADB 2014).

The quality of vocational education crucially depends upon the number and quality of technical teachers. The problem is that the two teacher training institutes in vocational education - the Technical Teacher Training College and the Vocational Teacher Training Institute - are not doing much training (ADB 2014). The Technical Teacher Training College has the capacity to train 80 teachers and the Vocational Teacher Training Institute, 240 teachers, but teacher vacancies in both the actual teachers being trained are much lower. At higher level in polytechnics, only $50 \%$ of teachers have been trained but more cannot be trained in the public training institutions because of the large number of vacancies for teacher positions in polytechnics (ADB 2014). 
The large number and share of private providers in the vocational space regulation of private providers are critical. The Technical Education Act of 1967 requires affiliation by private providers. Government teams are supposed to inspect institutions before they are approved. In principle, inspectors are supposed to make regular visits to ensure that standards are maintained. Regulating institutions are short of staff so inspection is minimal.

It is notable that in-firm training was being provided by almost $22 \%$ of all firms. However, formal sector firms are so small in number, and informal employment is such a large proportion of all nonagricultural employment that in-firm training would be consequential for only a small share of the workforce.

\section{Nepal}

Having a small formal economy, a very large proportion of the male labor force works in India since Nepal opened its border with India. Nepalese workers are also working in the Middle East, the PRC, and Southeast Asia. Similar with other countries in South Asia, most of its workforce are employed in the agriculture sector, and a vast majority of those in the nonagriculture sectors are in the informal economy. Because the majority of male workers are working in India, the female workers are doing farmwork. As a result, labor force participation rate among females (77.5\%) is higher compared with Viet Nam (73\%) or the PRC (67.5\%).

Nepal's Council for Technical Education and Vocational Training is responsible for formulating TVET policy, coordinating and developing TVET programs, and ensuring its quality. Nepal's TVET system has three levels: (i) short-term vocational program (< 1 year), (ii) upper secondary technical certificate programs (around 2 years), and (ii) post-secondary certificate and diploma program (3 years). In addition to technical schools, polytechnics, and institutes, public vocational schools called annex schools, which are formerly regular secondary schools, with additional physical facilities such as equipment and tools, offer TVET programs before and after school hours (ADB 2014). Private training schools have also grown significantly since the 1990s. From only three accredited private VTPs in 1991, the number grew to 450 as of 2013.

The Training Institute for Technical Instruction, which is highly competent, provides instructor training. It provides courses in management and special courses for private training providers. It also can provide long-term training at the diploma level in technical instruction and Bachelor of Technical Education together with Kathmandu University. For curriculum development and examination, the National Skill Testing Board has the capacity to test students for short-term vocational skills.

Private institutions must obtain approval to open new training programs. In Nepal, the number of private institutions as well as enrollment in private institutes are much greater than in public ones. Private institutions should obtain approval to open new training programs. For long-term programs, the approval of institutions by Nepal's Council for Technical Education and Vocational Training enables institutions to attract trainees on account of affiliation. But, for short-term vocational training, 2,012 institutions operate without affiliation. 


\section{Sri Lanka}

Sri Lanka, a middle-income economy, was an exceptional performer in the South Asia region very early in its development process in respect of both education and health (Alailama and Sanderatne 1997). Vocational education is not provided in Sri Lanka's secondary school system. Currently, there are around 2,077 registered training providers, including 291 government institutes, 648 other institutes, and 1,138 nongovernment vocational training providers. Nongovernment providers were about $55 \%$ of all institutions, but the public sector controlled the majority of students (70\% of the total). A separate ministry manages TVET in the country, and the apex institution Tertiary and Vocational Education Commission (TVEC) is carrying out policy development, planning, quality assurance, and some funding and research.

The Tertiary and Vocational Education Act No. 20 of 1990, the main legal document guiding TVET in Sri Lanka, stipulates the establishment of TVEC. In 2008, the University of Vocational Technology was created with a view to give those with TVET qualifications the opportunity to acquire university-level degree in a technical field. In addition, it prepares technical teachers through its faculty for the Bachelor of Education Technology degree. It is the only institution that provides pedagogical training for TVET teachers. But it faces the problem of lack of sufficiently qualified academic staff.

Education in Sri Lanka is administered centrally and at the provincial level. The Ministry of Education is responsible for drawing up national policies and plans, managing public schools, teacher education, and quality assurance. Provincial councils are in charge of implementing education policies. Each of the nine provinces has a provincial ministry of education. The National TVET Policy Framework sets the following goals, among many others, for TVET: (i) create a legal environment that facilitates development initiatives and effective implementation of TVET; and (ii) ensure that all TVET institutions in the state sector provide relevant statistics on an annual basis to the TVEC (UNESCO International Centre for Technical and Vocational Education and Training [UNEVOC] 2012).

The National Strategy on TVET Provision for Vulnerable People in Sri Lanka (2010) recognizes that a shift to an inclusive vocational training system will help to relieve the root causes of conflict and social tension on advantages of TVET. The six groups were selected according to vulnerability due to their limited access to skills training and finding employment, and were to be targeted by awareness campaigns. The identified groups consist of disadvantaged women, especially women who are heads of households; people with disabilities (mental and physical); disadvantaged youth (including school dropouts and former child laborers); the poor (including people from plantation, rural, and urban areas); persons affected by conflict; and family members of migrant workers.

While private training institutes, which operate on a fee basis, are well-established, the public sector continues to be the dominant player in the provision of TVET services. Nongovernment organization sector institutions include many religious and voluntary organizations that offer craft-level training targeted at unemployed youth, rural women, school leavers, and semiskilled or unskilled workers. The annual average intake of the TVET sector is more than 150,000 students, and the sector operates through an island-wide training service network. About $90 \%$ of the programs offered are at the certificate level, and $8 \%$ are at the diploma level, while the remaining $2 \%$ cover short-term programs of less than 
2 months. Computer and IT and finance and management courses account for about $44 \%$ of enrollment. Full-time course programs account for $77 \%$ of the total enrollment.

A large proportion of education and training is provided free of charge, together with a daily allowance. Some public training institutions charge fees for high-demand courses, such as computing, cosmetology, and bakery; and engage in training-related production to generate income. At present, the state TVET sector depends heavily on treasury funds and a significant extent on donor or lender funding and interventions for development activities (UNEVOC 2012).

Along with India (Malaysia and Singapore in Southeast Asia), Sri Lanka has adopted a national vocational qualification framework based upon competency consistent training.

Training assessment has shifted from being exam-based to a continuous assessment of competency (World Bank 2014). Sri Lanka provides for private institutions to be accredited by the government based on minimum training standards. By end of 2010, about 2,100 institutions had been registered, but, by end of 2011, only 901 courses had been accredited. All government providers are registered, but some private providers do not wish to register. All private institutions are not registered, and accredited mainly because of shortage of staff in the relevant government office to carry out this task.

In dealing with the economic relevance of TVET programs, due attention should be paid to the training needs of the emerging high-growth sectors of the economy. The tourism industry is one such example, and it is, at present, faced with a human resource crisis. Currently, the Sri Lanka Institute of Tourism and Hotel Management functions as the only training provider.

Foreign employment accounts for about $24 \%$ of the labor force and ranks as the secondhighest foreign exchange earner. The analysis also revealed that departures for foreign employment account for $20 \%$ of job placements. In terms of relevance, this is an important area requiring the immediate attention of TVET providers. At present, training for those who seek foreign employment is being conducted by both public (Sri Lanka Bureau of Foreign Employment) and private institutes. The programs conducted are certificate-level courses and cover about $20 \%$ of departures for foreign employment per year. The duration of the programs vary from 3 days to 25 days, with training programs for employment in the Middle East (which are 15 days), accounting for about $93 \%$ of total programs conducted by private providers.

Despite several noteworthy milestones, TVET in Sri Lanka faces unresolved and emerging challenges. The following are identified as key concerns in the country's TVET sector: (i) improving the quality and relevance of TVET programs and increasing the accessibility, efficiency, and effectiveness of training delivery systems; (ii) professional preparation of teachers and inadequate participation of the industries (users) in the design and delivery of TVET courses; (iii) inadequate quality assurance and quality control systems and strengthening the national vocational qualifications system; (iv) inadequate emphasis on training of individuals seeking foreign employment; and ( $v$ ) inadequate policy support, particularly to promote private and nongovernment organization sector participation (Innovative Strategies in Technical and Vocational Education and Training for Accelerated 
Human Resource Development in South Asia: Country Paper for Sri Lanka, by Sunil Chandrasiri; and ADB 2013).

\section{Challenges to the Technical and Vocational Education and Training Systems in South Asia}

TVET systems are always built around a sound foundation of general academic education. As discussed in the previous section, the quantity and, more importantly, the quality of education in South Asia is generally below par. Inequality in access and outcomes across gender, income level, and social class is also a serious concern. Although Sri Lanka is historically performing better than the rest of South Asia in terms of attainment, the quality of education remains a challenge.

Because of the lack of quality education and TVET, especially at the higher levels, the supply of skilled labor in many developing countries is not sufficient to meet the challenges of growing demand and changing skill requirements (Chen et al. 2013, World Bank 2012). Concerns about the quality of graduates are widespread, with employer surveys revealing that university or vocational school graduates usually lack higher-order thinking skills, English communication skills, training, as well as soft skills (e.g., integrity, reliability, flexibility) that the employers require (Blom and Saeki 2011). In addition, there is a mismatch between the level of skills that employers require and the supply of employable skills in the labor market today.

While general academic education prepares young people for the labor market and work transition to some extent for semiskilled work in manufacturing and modern services, vocational education and training can help to prepare young people for relatively lowlevel skilled jobs. While there are a considerable share of students at the secondary and higher secondary levels, there are hardly any children in vocational programs in South Asia, especially at the higher secondary levels.

Thus, one of the major challenges facing South Asian countries is simply that general academic education has to be universalized before children will be ready to enter vocational education after completing 8 years of basic education, well-prepared to acquire both transversal or soft skills as well as vocational ones.

It is remarkable how much commonality there is in the weaknesses and problems with TVET systems, and the rather poor outcomes, across all South Asian countries. Weaknesses of South Asia TVET systems under three heads will be examined: inputs, processes, and outcomes.

\section{Inputs}

Access to education and skills training remains limited. South Asia failed its children by not ensuring universalization of schooling up to at least class 8 early on in its development process. The result is that there are millions already on the workforce who do not have 8 completed years of education. So, historically, the paradoxical situation is that most of the children accessing formal TVET consist of young males who can afford to stay more years in school having completed at least class 8 , but they have strong white collar job aspirations. As a result, those who do enter formal TVET actually have no interest in acquiring a 
vocational skill since their hope is for a government or a white collar job. Meanwhile, youth who do not complete 8 years of schooling are automatically excluded from entering TVET, since 8 years of schooling is a common prerequisite. In other words, those who would have benefited more from vocational education end up getting excluded from it. This is the foundational reason why vocational education has such a low rate of enrollment.

Historically, the groups who have been most likely not to complete 8 years of schooling are those who are most excluded from TVET, although they are the ones who need it most: the poor, the girls, and the rural population. On the other hand, the shortage of skilled workers reflects the capacity constraints in India in terms of skills development. While India has well-institutionalized public vocational education and training systems, they are not large enough to accommodate large numbers of school graduates.

\section{Process}

The lack of qualified technical teachers is one of the factors causing the poor quality of training across South Asian countries. This is main cause by two constraints: (i) the lack of capacity to train instructors; and (ii) red tape, which makes recruitment and hiring to fill vacant posts difficult. There is usually no formal policy or guideline for the professional development of TVET instructors. They usually receive little pedagogical training, let alone competency-based training. They also have few practical skills, and industry experience is not necessarily a requirement to become an instructor.

The fact that two countries in the region, India and Sri Lanka, now have a national vocational qualification framework may well mean that competency-based training may be required for instructors and not just for trainees. But this is clearly in the future.

The labor market information available is inadequate. None of the countries in South Asia have a labor market information system in place, although discussion around the subject has taken place at least in India and in Sri Lanka.

Governments provide inadequate financial allocation for skills training. The government contribution to vocational education in Bangladesh does not exceed $1.5 \%-2.5 \%$ or $2.3 \%$ of education spending. In Nepal, TVET received about $1.2 \%$ of the education budget and only $0.2 \%$ of the total government budget.

There is little industry involvement. The most effective TVET systems in the world are those where there is strong employer involvement. Where there is weak involvement of employers in the system are the ones that are government-driven as well as supply-driven. Employment involvement can take two forms: one is that enterprises offer training in-firm; the other is that employers get involved in TVET systems at the preemployment stage. The latter should ideally take at least five forms: (i) assisting curriculum design for industry- or occupation-specific programs; (ii) the offer of internships, so that all TVET institutions offer practical training; (iii) the offer of their own staff as trainers at courses offered by VTPs or in vocational secondary schools; (iv) assessment; and (v) career guidance prior to placement.

The lack of employer involvement leads to slow and inadequate response to changes in the labor market. This situation is exacerbated by the fact that training institutions usually do 
not carry out analysis for skills in demand locally. There is usually no position for training and placement officers in either vocational school or college.

This situation has been remedied partially in India by the creation of sector skill councils being incubated by the NSDC. The sector skill councils, however, are in an incipient stage and still beginning to get established, and only time will show their involvement of industry in the development of national occupational standards. In Sri Lanka, there is some engagement of industry, unlike in the two other smaller South Asian countries. In Sri Lanka, as in India, sector or industry advisory councils have been created under the aegis of TVEC.

Supply responsiveness is limited. When TVET systems are government- and supply-driven, the responsiveness of TVET is limited. This situation leads to curriculum development, the introduction of new courses and the closing of obsolete courses becoming a timeconsuming process. The government is unable to introduce new courses to keep up with technological changes in firms. Thus, in Bangladesh, the World Bank (2007) reported that training in agriculture was in demand, especially in horticulture, poultry, agro-based food, dairy and aquaculture, as well as leather making, but it failed to materialize. It takes a long time to develop new courses and get them introduced in TVET institution. In addition, on account of administrative rules which make hiring centralized, it is difficult to recruit new staff on a contractual basis to respond to demand for new courses from the market.

There is lack of vertical and horizontal mobilities in TVET. All across South Asian countries, it is difficult for graduates of vocational programs in secondary school to gain admission to high-level technical program at the university or polytechnic level. Just as this vertical mobility is restricted if a young person decides to register in a vocational program, similarly horizontal mobility from general academic education to a vocational program or vice versa is highly restricted. In India, there has been an effort since the national skill qualification framework was made official, that such vertical mobility will be made easier.

Accreditation programs are weak. Given that private providers tend to enroll most of the vocational students, quality assurance in such institutions is dependent upon proper regulation. But in none of the countries does the regulator have the capacity to actually ensure such quality.

The administration of educational programs is highly centralized. If the administration of educational institution is centralized, then it is very difficult to ensure flexibility that normally comes with autonomy. This is also a problem that is found in all South Asian countries. This is really a normal problem in government-driven and supply-driven vocational programs.

In addition, there is a problem of lack of integration and coordination. For instance, in Sri Lanka, the TVET system has been unified under one ministry, but the difficulty is that the providers all created at different times and under different legal provisions have not been integrated. The result is that fragmentation continues in practice at the district and provincial levels. In India, vocational training is offered by 21 ministries of the central government. In addition, these are actually delivered by state governments across 28 states of India. The coordination function has been missing all together until recently. A new Ministry of Skill Development and Entrepreneurship was created in late 2014, but it remains to be seen how it will perform. 
Given all these problems on the input and process sides of vocational program, it is not surprising that outcomes are less than desirable.

\section{Outputs}

India's TVET system needs to be adequately prepared to equip the young workforce with skills that industries require to meet today's changing skill requirements, which are a result of rapid globalization and technological innovation (Okada 2012).

Employability of students is low and widely varied across cities and states in India. Results of a nationwide multidimensional skill assessment test-the Wheebox Employability Skill Test-showed that only slightly over a third of the students who took the exam were found employable (Cll, PeopleStrong, and Wheebox 2013). Performance differed widely across cities, states, skill domains, age groups, and gender. Younger students (39\% passing rate) performed better than older ones (28\%), while female students (42\%) fared better than male students (30\%).

In Bangladesh, a World Bank tracer study involving 2,300 graduates of public and private TVET institutions in 2003 found employment rates to be low. In Bangladesh, one study indicated that only $9 \%$ were employed, $45 \%$ were pursuing higher education, and $46 \%$ were unemployed. Of those who were employed, about 38\% took less than 6 months to get a job and another $15 \%$ took up to 1 year. The study indicated that the unemployment rate for technical and vocational graduates was above that of general graduates. In Nepal, employment of skills training graduates is between $30 \%$ and 50\%. In Sri Lanka, a study in 2005 has shown weak linkages between training and employment. About three-quarters of trainees were employed after training and a quarter were unemployed, with another $27 \%$ stating that training was not helpful in finding a job. About one-third of those employed were working in fields other than that of their training. 


\section{CHANGES IN SKILL DEMAND AND SUPPLY AND WAGE STRUCTURE}

\section{Highlights}

- Changes in demand of skilled labor and its supply have influenced wage inequality in South Asian economies.

- Technological change is driving the increasing skilled labor demand.

- The expansion of skilled workers that matches the pace of technological progress can help reduce both skill-job mismatches and wage inequality.

In recent years, many developing countries have experienced rapid development of both education and technology. Evidence shows that the relative demand and supply of skilled workers influence wage inequalities in Asia. Guided by the existing literature, this section focuses on the changes in demand and supply of skilled workers and wage structure across education levels in selected South Asian and Southeast Asian economies. It also highlights the implications of technological development in South Asia and other Asian economies on labor demand changes and wage distribution at the enterprise level.

\section{A. Skill Upgrading, Wage Structure, and Skill Premium in Labor Markets}

The analysis of the determinants of labor demand and supply and differences in wages and employments among individuals has been one of the important topics in labor economics literature (Autor and Katz 1999). Theoretical framework explains that wage differences are determined by supply and demand factors and institutional (noncompetitive) factors.

Wage of individuals can be expressed as a sum of competitive wage and deviation from competitive wage that reflects institutional or noncompetitive forces (Freeman and Katz 1994, Bound and Johnson 1992). In the United States, most of the changes in wage inequality can be explained by simple demand-and-supply framework (Katz and Murphy 1994). Behind the increasing wage inequality in the country was a shift toward for more skilled workers. 
Institutional factors, as union and minimum wage law, can influence the wage distribution. ${ }^{25}$ Union density can explain around $20 \%$ of rise in male earnings inequality in the United States (Freeman 1993). After adjusting for selection issue in union status of workers, Card (1998) concluded that declining unionization can explain about $12 \%$ of the rise in wage inequality. Increase in the 50-10 wage differential in the 1980s can be attributed to the decline in the effective federal minimum wage (Lee 1999). Differences in labor market institutions across countries played a significant role in patterns of wage inequality (Freeman and Katz 1994, 1995).

Skill-biased technological changes play an important role on the changes in relative labor demand and wage distribution, especially in advanced economies (Lee and Wie 2015a; Berman et al. 1998, 1994; Katz and Murphy 1992). Despite an increase in supply of skilled workers, demand shifts toward more skilled workers in the services sector caused a rise in skill premium in seven Asian countries: Cambodia, the PRC, Indonesia, Mongolia, the Philippines, Thailand, and Viet Nam (Di Gropello and Sakellariou 2010).

A number of studies using labor force survey data from the PRC have established that the increasing demand for more skilled workers can explain the increasing skill premium in the PRC, especially during the post-reform period (1988-2001) (ADB 2014, Meng 2012, Xu and Li 2008, Knight and Song 2003b). Because of institutional reforms in the labor market, there was a dramatic increase in the demand for skilled workers in the PRC, and, at the same time, an increase in wage premium occurred within narrowly defined groups (Zhang et al. 2005). Knight and Song (2003b) identified the increase in wage differential in favor of skilled workers as a major factor behind the increase in wage inequality between 1988 and 1994. A similar pattern was observed between 1998 and 2000, and Xu and Li (2008) confirmed that the rise in wage inequality during the period was related to the rising skill demand by foreign-owned firms in the country. Han et al. (2012) suggest that, by raising the returns to education, trade liberalization contributed to increase in wage inequality in the PRC.

In India, the demand for skilled male workers has been increasing since the 1960s (Chamarbagwala 2006). In the 1990s, the greater demand for skilled workers was mostly due to the increasing level of technology in each industry, as well as the increase in output and capital-skill complementarity, combined with rapid capital investment from India (Berman et al. 2005). Studies have confirmed that the increasing returns to skills, especially of males, due to skill-biased technological changes within industries were the driving force behind the increasing income disparity across skills and between gender in the country (Mehta and Hasan 2012, Kijima 2006, Chamarbagwala 2006). According to Mehta and Hasan (2012), around one-third to two-thirds of the increase in wage inequality in India is due to changes in industry wages and skill premiums. Menon and Rodgers (2008) suggest that trade liberalization increased competition and reduced the discrimination against female workers, and, as a result, women's relative wages and employment increased between 1983 and 2004.

Literature on other Asian countries report similar trends in wage inequalities and skill premium with other countries. In Bangladesh, returns to education is higher in urban area than in rural area, and that gaps in observed qualifications, including education and experience, are important determinants of gender-wage gap (Asadullah 2006, Kapsos 2006). In Sri Lanka,

${ }^{25}$ Estimating independent effect of institutional factors on wage is, however, difficult as they can be affected by supply and demand. 
using data from the 1999-2000 Sri Lanka Integrated Survey, Ajwad and Kurukulasuriya (2002) found that most of the wage disparities across ethnic groups in the formal sector could be explained by education and experience. In the Republc of Korea, the rising wage inequalities across educational levels since the mid-1990s, despite the increase in supply of skilled labor, could be explained by increasing demand for skilled labor (Jeong et al. 2004).

In Indonesia, wage inequality narrowed with economic growth between 1990 and 2003, but the wage inequality trend reversed thereafter. From 1990 to 2003, real wages of less-educated (unskilled) workers grew as the economy expanded, but contracted after 2003, while the wages of highly educated (skilled) workers grew steadily. Although the decline in relative supply of less-educated (unskilled) workers partly explains the increase in their real wages before 2003, as shown in Table 13, the increase in the relative supply of highly educated (skilled) workers cannot explain the increase in their real wage in 2000-2009 (Lee and Wie 2015a). Lee and Wie (2015a) found that the increase in relative demand for skilled labor in Indonesia, which is related with the increase in the transfer of foreign technology through foreign direct investment and imported goods in the country, largely explains the increase in the wage premium for skilled workers in 2000s.

In the Philippines, demand for skilled labor and wage premium has been increasing over the last 20 years due to openness to advanced technology and international competition (Di Gropello et al. 2010). Luo and Terada (2009) confirmed that income inequality in the country between 2003 and 2007 was largely associated with the return to education.

\section{B. Micro Level Analysis of Skill Composition and Wage Structure}

The literature suggests that change in relative labor supply and demand effect is a key factor in affecting the structure of wage and inequality. Using labor force survey data in selected South Asian and Southeast Asian countries, this section analyzes the evolution of employment composition and wage structure by skill group.

This section examines whether supply and demand for skilled labor are a driving force behind the increase in wage inequality by skill level. Using long-run survey of labor force, the evolution of wage gap is examined by education and gender in target countries.

To examine the evolution of wage structure related to skills, good quality micro data is needed with detailed information of wage and skill level of workers. The consistency and representativeness of data over the long period are also essential to examine whether the change in wage structure is a secular trend not caused by temporary shock in the economy. Analysis is limited by the availability of quality data in selected countries in South Asia and Southeast Asia.

India

To analyze the changes in demand and supply of skilled workers in India, four rounds of the India National Sample Survey Employment and Unemployment data (1993-1994, 
Figure 16: Trends in Wage Inequality in India
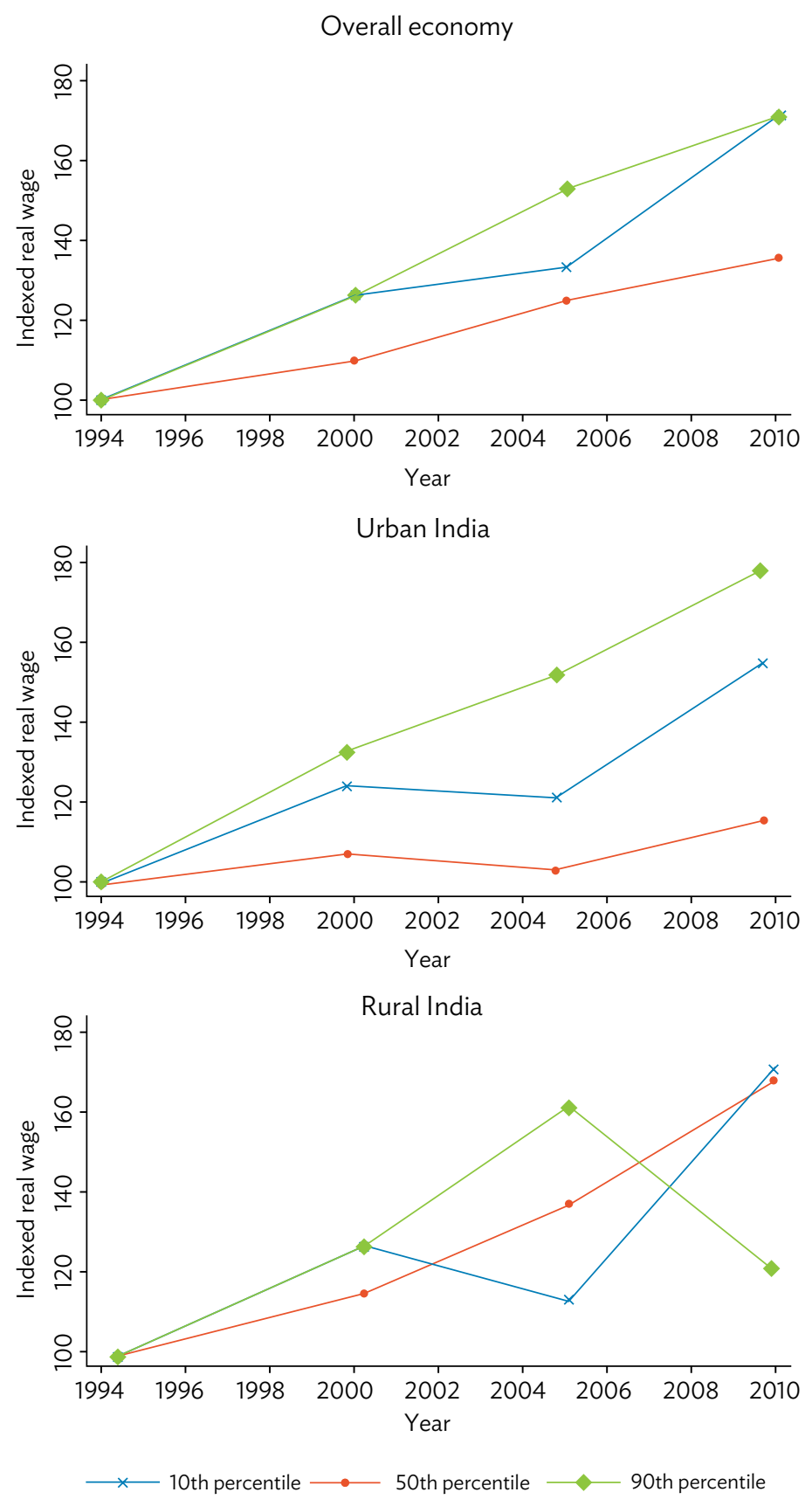

Note: Sample includes all full-time paid workers.

Source: Author. 
1999-2000, 2005-2006, and 2009-2010) were employed. ${ }^{26}$ Each wave had more than 100,000 samples on average, and contained both employed workers in the formal sector and self-employed and/or unpaid workers in the informal sector.

\section{Wage Inequality in India}

Since the mid-1990s, wage inequality in India has gradually deteriorated (Figure 16). One should note a regional difference in the trends of wage inequality. Urban India experienced constant increase in wage inequality over the period 1994-2010, in contrast to rural India where the inequality improved.

In urban India, the collapse of the median group mainly contributed to increasing wage inequality over the sample period. The median group (proxied here by the 50th percentile) gained the least benefit from the economic growth, while the skilled one (proxied here by 10th percentile) benefited the most.

The movements of Gini coefficients in Figure 17 also confirm the difference in the trends of wage inequality across regions. Gini coefficients increased in urban India while sharply declining in rural India.

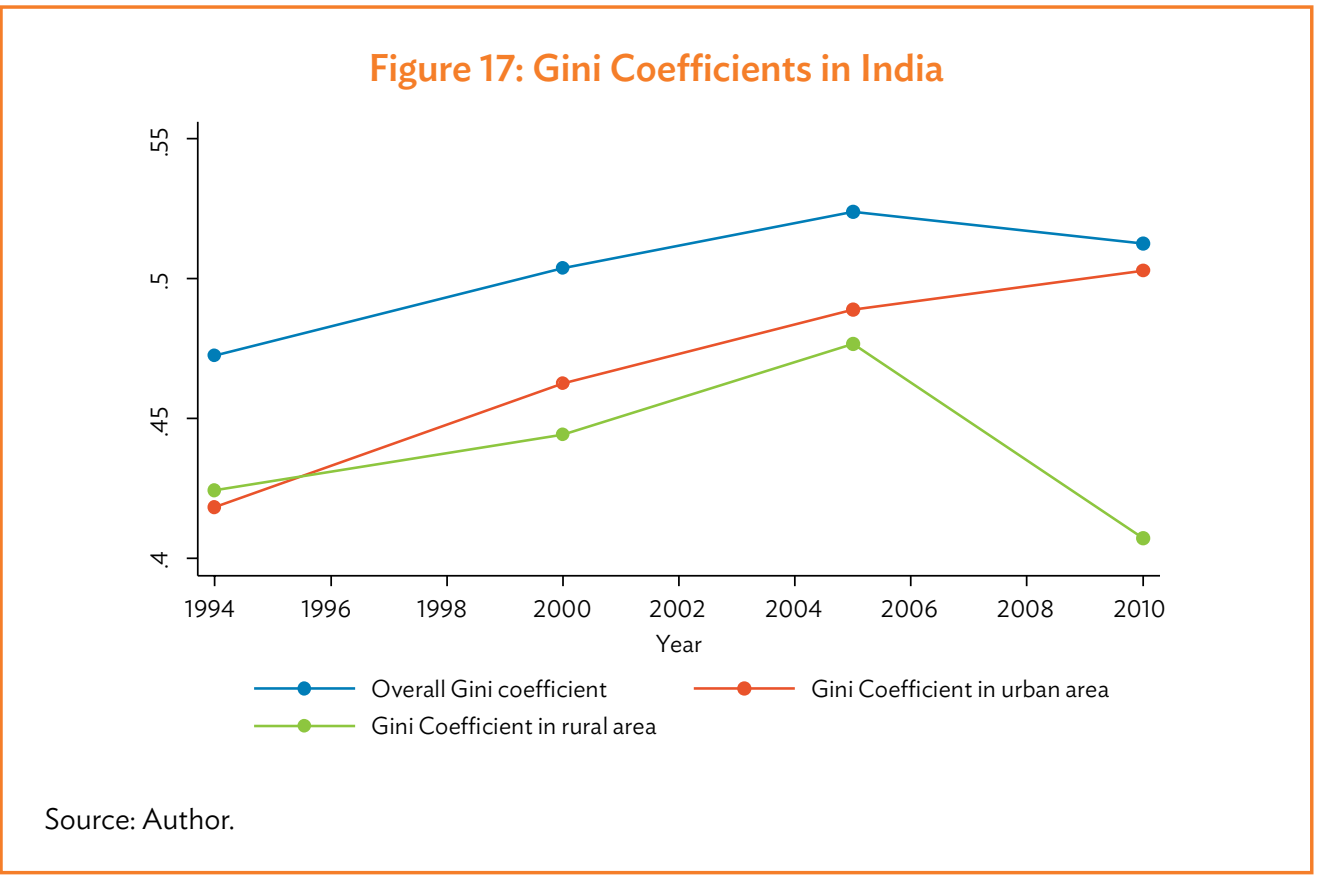

\footnotetext{
${ }^{26}$ Please refer to ADB (2015) for details. The analysis on labor market in India in this report is based on the one in ADB (2015) that covers a longer period, 1988-2010.
} 


\section{Skill Premium Trends}

As in ADB (2015), the relationship between wage inequality and skill premium was examined. Figure 18 suggests the change of skill premium as a driving source behind increasing and/or decreasing wage inequality in urban and rural India. College premium in urban India increased constantly from 1994 to 2010, while in rural India, it peaked in 2000 and declined thereafter.

Figure 18: Skill Premium in India
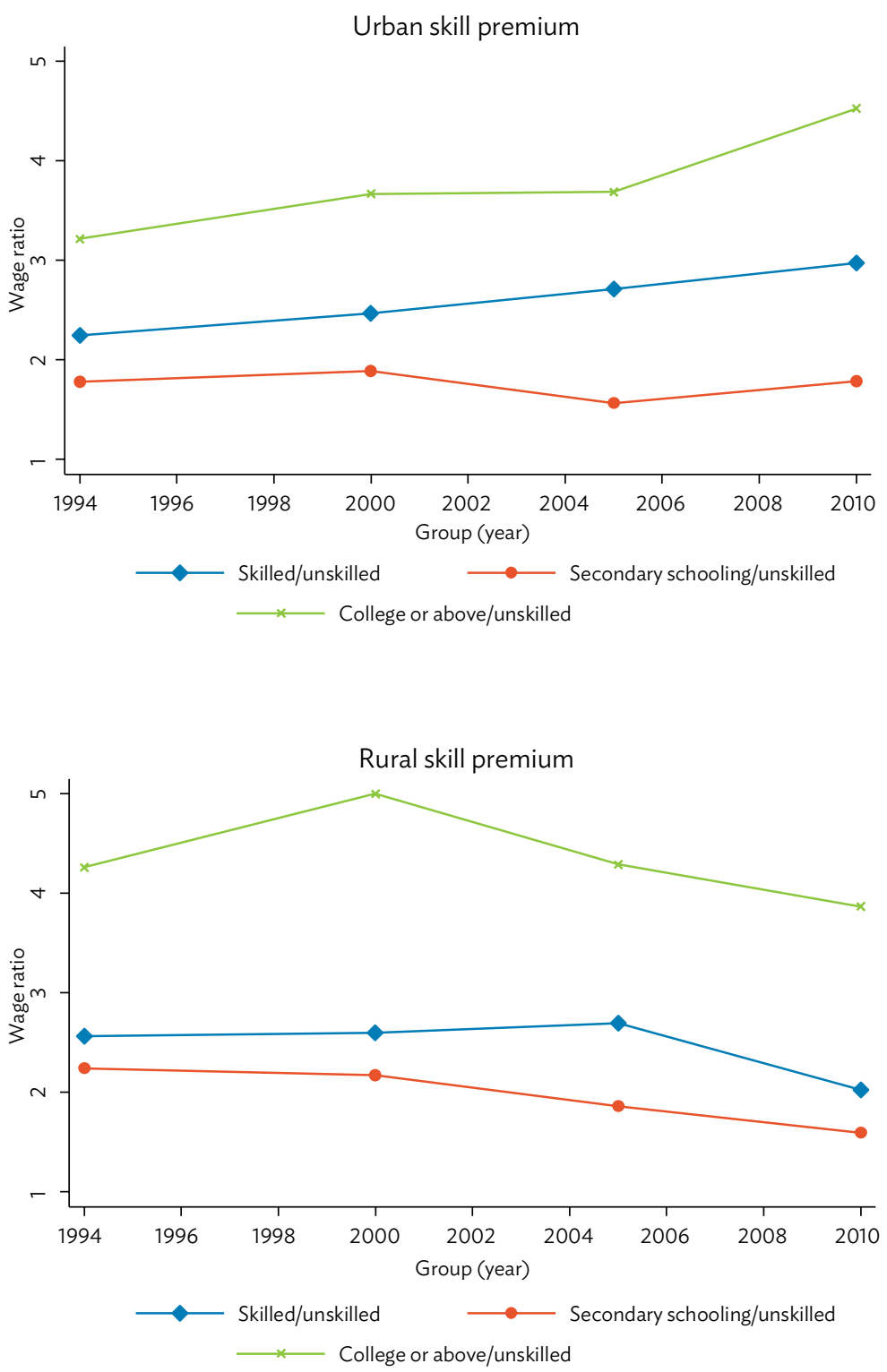

Source: Author. 


\section{Residual Wage Inequality Implications}

Within-group wage inequality in India was examined using the regression of log weekly wage on experience (up to quartic and interacted with sex and education level dummies), and years of schooling (ADB 2015). The residuals from this regression capture the dispersion of wages within each demographic group. The difference in the log wages of those at the 19th and at the 10th percentiles of the distribution is then calculated.

A steady increase in residual inequality only in urban area is demonstrated in contrast to a mere change in residual wage differentials in rural India over the period 1994-2010 (Figure 19). This indicates increase in wage inequality even within narrowly defined demographic group, especially in urban India.

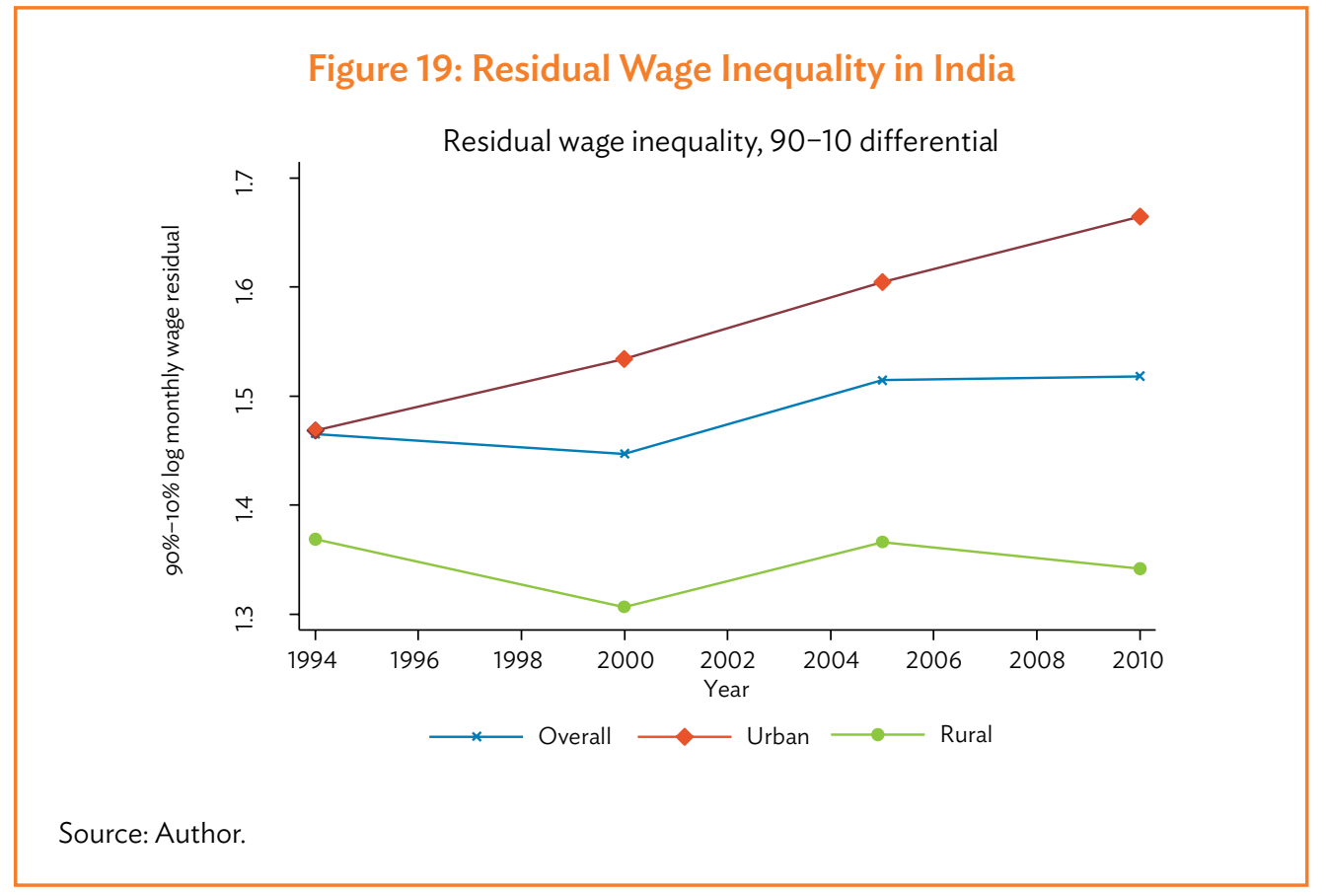

\section{Labor Market Participation in India}

ADB (2015) examines the changes of labor market participation rate across different labor markets and gender over the period 1998-2010, a longer period than the sample period in this report. A gender gap in labor force participation rates and sharp changes in skill composition of labor force over the period 1994-2010 is shown (Figure 5.12 in ADB 2014). For both female and male workers, the proportion of unskilled workers (workers with education level equal or lower than junior high school) decreased over time, while that of skilled workers increased.

A sharp increase in the proportion of workers with tertiary education prevailed only in urban India. Female labor market participation in rural India is much higher than that in the urban area, implying income effect as the driving force behind the low labor market participation rate of urban area. 


\section{Demand and Supply Analysis}

As in ADB (2015), by employing the methodology of Katz and Murphy (1992), the changes of relative wages and relative supplies were investigated. Two sample groups were constructed: wage sample and count sample. To examine the movement of relative supply and relative wage series of various demographic groups, the sample was divided into 64 categories (by region, gender, four education levels, and four experience levels). ${ }^{27}$

The summary statistics of all workers in the sample are provided in Table 17. Many of the workers belonged to the informal sector and did not have reported wage variables. According to the summary, the proportion of illiterate workers sharply declined over the sample period, 1994-2010, while workers with university diploma or higher education sharply increased. The summary statistics show a slight decline in female labor market participation of rate around $25 \%$ and a modest changes in the experience distribution of workers.

\section{Evolution of Relative Wages in India}

Changes in the relative wages of India for the sample period (1994-2010) are shown in Table 13. Overall, relative wage increased except for the period 2000-2005. In addition, female and more-experienced workers benefited the most over the sample period. However, in the recent period, young workers gained the most due to their high skill level.

Gains from economic growth varied across their skill levels. The least-skilled group and the most-skilled group were the beneficiaries over the sample period. At the same time, relative wage of the median group did not grow as much as that of other groups.

Region-education disaggregation reports a difference in the changes in relative wage across regions. The labor groups that gained the most are the workers who are illiterate in rural India and those with university degree in urban India.

\section{Evolution of Relative Supplies in India}

Table 14 suggests that the change in the wage structure of India cannot be fully explained by the supply and demand analysis. Over the whole periods, except in 2005-2010, the relative supply of skilled labor sharply increased, suggesting that supply-side change cannot explain the increase of relative wage of skilled workers. However, within the supply-demand framework, it can be argued that the huge decline in relative supply of unskilled workers over the sample period in Table 14 contributed to the increase in relative wage of leastskilled group in Table 13. Also, slight decrease in more experienced workers may be the factor of increasing premium to experience.

As argued in ADB (2015), a slight increase in relative supply of female workers in Table 14 implies demand shift favoring female workers. According to Lee and Wie (2015b), relatively high wage gains of the least- and middle-skilled workers, as well as improvement of women's qualification, favored female workers both in urban and rural India.

$\overline{27}$ See ADB (2015) for further details on the methodology. 
Table 13: Real Weekly Wage Changes for Full-Time Workers in India, 1994-2010

\begin{tabular}{|c|c|c|c|c|}
\hline \multirow[b]{2}{*}{ Group } & \multicolumn{4}{|c|}{ Changes in Log Average Real Weekly Wage (multiplied by 100) } \\
\hline & 1994-2010 & 1994-2000 & $2000-2005$ & $2005-2010$ \\
\hline All & 30.7 & 17.4 & -1.8 & 15.1 \\
\hline \multicolumn{5}{|l|}{ By region } \\
\hline Rural & 32.4 & 16.7 & -0.0 & 15.7 \\
\hline Urban & 27.4 & 18.8 & -5.3 & 13.9 \\
\hline \multicolumn{5}{|l|}{ By gender } \\
\hline Male & 29.4 & 17.9 & -0.5 & 12.0 \\
\hline Female & 34.9 & 16.0 & -6.1 & 25.0 \\
\hline \multicolumn{5}{|l|}{ By education } \\
\hline Illiterate & 43.6 & 18.9 & 1.6 & 23.1 \\
\hline Elementary school & 29.3 & 19.3 & 2.3 & 7.7 \\
\hline Secondary school & 10.9 & 12.0 & -8.4 & 7.4 \\
\hline College or above & 38.8 & 22.0 & -4.8 & 21.7 \\
\hline \multicolumn{5}{|l|}{ By experience } \\
\hline $1-10$ years & 30.2 & 14.8 & -5.0 & 20.4 \\
\hline $11-20$ years & 28.4 & 14.8 & -3.0 & 16.6 \\
\hline $21-30$ years & 29.4 & 20.1 & -1.8 & 11.1 \\
\hline$\geq 30$ years & 34.4 & 19.2 & 1.3 & 14.0 \\
\hline \multicolumn{5}{|l|}{ By region and education } \\
\hline \multicolumn{5}{|l|}{ Rural workers } \\
\hline Illiterate & 46.7 & 19.9 & 1.4 & 25.3 \\
\hline Primary school & 32.6 & 18.7 & 3.3 & 10.5 \\
\hline Secondary schooling & 6.2 & 8.5 & -4.6 & 2.3 \\
\hline College or above & 15.5 & 14.4 & -8.9 & 10.1 \\
\hline \multicolumn{5}{|l|}{ Urban workers } \\
\hline Illiterate & 25.7 & 13.0 & 2.4 & 10.4 \\
\hline Primary school & 21.5 & 20.6 & -0.0 & 0.9 \\
\hline Secondary schooling & 16.4 & 16.1 & -12.8 & 13.2 \\
\hline College or above & 48.6 & 25.1 & -3.0 & 26.5 \\
\hline
\end{tabular}

Source: Author.

The decline in skilled labor in the recent period, 2005-2010, needs further examination due to the global economic crisis in 2008.

\section{Demand Shift toward Skilled Workers}

Tables 13 and 14 provide evidence for the existence of a demand factor increasing relative wage and employment of skilled workers, especially in urban India. The existence of demand factor was addressed using the supply-demand analysis suggested by Katz and Murphy (1992) and using the 64 different labor groups in our sample. The inner products 
Table 14: Relative Monthly Supply Changes for Full-Time Workers in India, 1994-2010

\begin{tabular}{|c|c|c|c|c|}
\hline \multirow[b]{2}{*}{ Group } & \multicolumn{3}{|c|}{$\begin{array}{l}\text { Changes in Log Share of Aggregate Labor Inputs } \\
\text { (multiplied by 100) }\end{array}$} & \multirow[b]{2}{*}{$2005-2010$} \\
\hline & 1994-2010 & $1994-2000$ & 2000-2005 & \\
\hline \multicolumn{5}{|l|}{ By region } \\
\hline Rural & -6.6 & -4.9 & -8.9 & 7.1 \\
\hline Urban & 5.9 & 4.5 & 7.1 & -5.7 \\
\hline \multicolumn{5}{|l|}{ By gender } \\
\hline Male & -0.8 & -0.6 & -1.5 & 1.3 \\
\hline Female & 4.9 & 3.8 & 8.4 & -7.3 \\
\hline \multicolumn{5}{|l|}{ By education } \\
\hline Illiterate & -62.0 & -18.1 & -37.0 & -6.8 \\
\hline Elementary school & -17.2 & -12.9 & -6.2 & 1.9 \\
\hline Secondary school & 6.0 & 7.9 & -37.3 & 35.4 \\
\hline College or above & 39.1 & 12.5 & 50.9 & -24.3 \\
\hline \multicolumn{5}{|l|}{ By experience } \\
\hline 1-10 years & 35.6 & 9.8 & 26.8 & -1.0 \\
\hline $11-20$ years & -4.6 & -2.4 & -1.2 & -1.0 \\
\hline $21-30$ years & -11.0 & 0.9 & -7.5 & -4.4 \\
\hline$\geq 30$ years & -5.6 & -3.8 & -8.7 & 6.9 \\
\hline \multicolumn{5}{|c|}{ By region and education } \\
\hline \multicolumn{5}{|c|}{ Rural workers } \\
\hline Illiterate & -66.4 & -19.5 & -40.9 & -5.1 \\
\hline Primary school & -6.4 & -12.3 & -10.1 & -16.0 \\
\hline Secondary school & 24.8 & 10.4 & -29.6 & 44.1 \\
\hline College or above & 46.0 & 14.6 & 72.0 & -40.6 \\
\hline \multicolumn{5}{|l|}{ Urban workers } \\
\hline Illiterate & -48.8 & -12.8 & -23.0 & -12.6 \\
\hline Primary school & -36.4 & -13.9 & 0.4 & -22.2 \\
\hline Secondary school & -9.5 & 6.2 & -43.3 & 27.6 \\
\hline College or above & 37.1 & 12.0 & 44.3 & -19.1 \\
\hline
\end{tabular}

Source: Author.

of the changes in these measures of wages and supplies between each pair of these 5 years were calculated.

The results for the supply-demand analysis in Table 15 present positive signs for most of sample period except for the most recent years, indicating demand shift favoring skilled labor. Further research is needed to determine if the resulting demand shift is related to trade or technology. 
Table 15: Inner Products of Changes in Wages with Changes in Supplies

\begin{tabular}{|l|c|c|c|}
\hline \multirow{2}{*}{ End period } & \multicolumn{3}{|c|}{ Starting period } \\
\hline 2000 & 1994 & 2000 & 2005 \\
\hline 2005 & 0.0040 & & \\
\hline 2010 & 0.0270 & 0.0095 & \\
\hline
\end{tabular}

Notes: Numbers represent inner products between changes in relative wages and change in relative supplies of 64 cells. Each inner product is calculated using changes across column period and row period. Relative wage measure is constructed from the sample of full-time workers in the formal sector, while relative supply is calculated from the sample of workers in the formal sector.

Source: Author.

India has experienced increasing wage inequality since the 1990s (ADB 2015). The supplydemand analyses present demand shift favoring more educated workers in India in the late 1990s and early 2000s. To conclude tentatively, widening wage differential between skilled and unskilled workers in urban India seems to be the source of rising inequality in India.

\section{Sri Lanka}

For the analysis on demand and supply of skilled labor in Sri Lanka, four sets of Sri Lanka labor force survey were used in the years 2000, 2004, 2008 and 2012. Each round had around 60,000 observations that were representative of Sri Lankan economy. The survey also employed two-stage clustered sampling and post-estimated survey weight for researchers to acquire accurate estimates.

The survey included detailed information of workers such as demographics, education, and workplace. Sri Lanka has a large informal sector, estimated at around $40 \%$ and consisting of self-employed and unpaid family workers. The data included wage variable of formal sector workers only.

\section{Wage Inequality in Sri Lanka}

Over the period 2000-2012, benefits of economic growth were equally distributed across workers with different skill levels, implying improvement of wage inequality in Sri Lanka (Figure 20). The benefits were largest for the median group (proxied here by the 50th percentile) and the least-skilled group (proxied here by the 10th percentile), but the lowest for the skilled group (proxied here by the 90th percentile) from 2000 to 2012.

This pattern also appears in the Gini coefficient of Sri Lanka (Figure 21). Overall Gini coefficients as well as female and male Gini coefficients were estimated separately. All of the coefficients declined over the sample period, confirming decreasing wage inequality. 
Figure 20: Indexed Wage Inequality in Sri Lanka

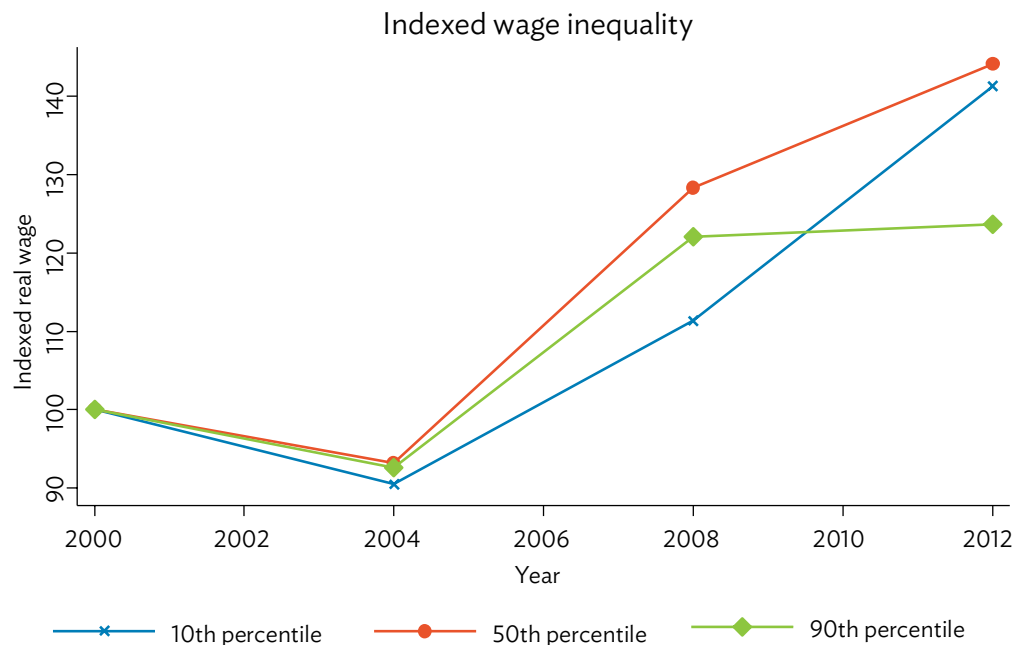

Sample: Wage sample (full-time paid workers).

Source: Author.

Figure 21: Gini Coefficients in Sri Lanka

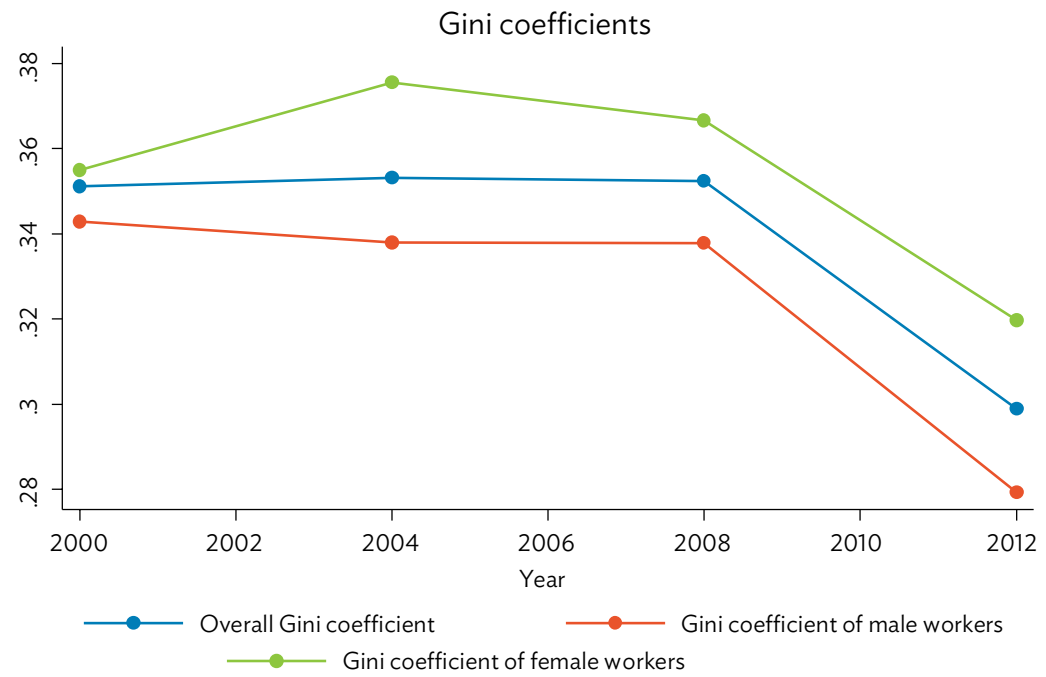

Sample: Wage sample (full-time paid workers).

Source: Author. 
Skill Premium and Wage Inequality

Can the movement of skill premium explain wage inequality in Sri Lanka? All of the measures of skill premium, including the premium to college or higher education, showed a slight increase over the period 2000-2008, and a sudden and sharp decline thereafter.

Skill premium of female and male workers show slightly different trends over time. Skill premium to tertiary education for male workers constantly decreased from 2000 to 2012, while that for female workers increased until 2008 and declined thereafter (Figure 22). The difference between female and male skill premiums suggests the possibility that wage trends for both females and males can be explained by the difference in the relative supply of workers.

\section{Labor Force Participation}

Changes in the labor market participation rate by gender and educational groups over the period 2000-2004 in Sri Lanka are shown in Figure 23. Labor force participation of female in Sri Lanka was constant at around $40 \%$, which was much lower than that of male, but much larger than that in India.

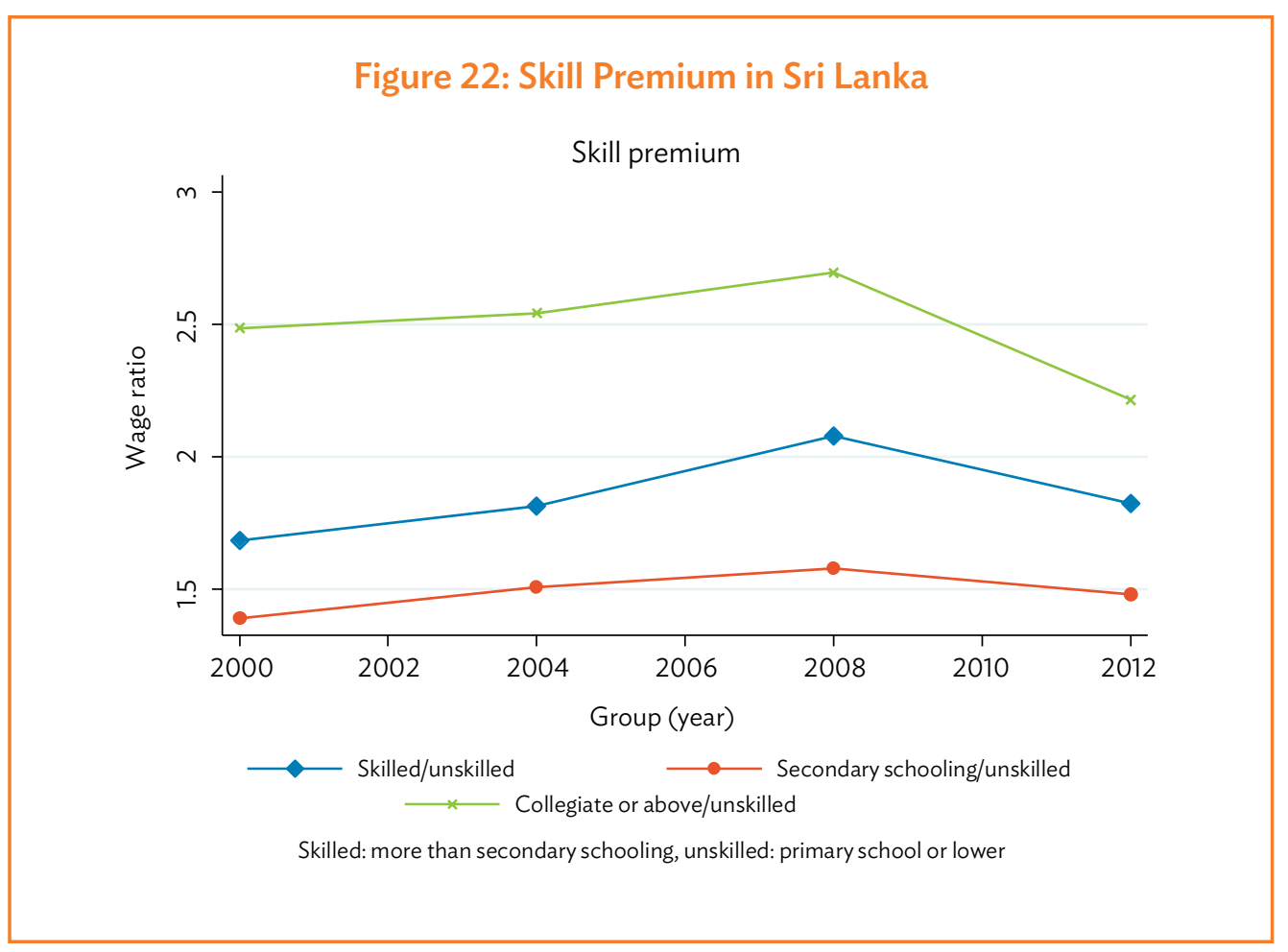

continued on next page 
Figure 22 continued

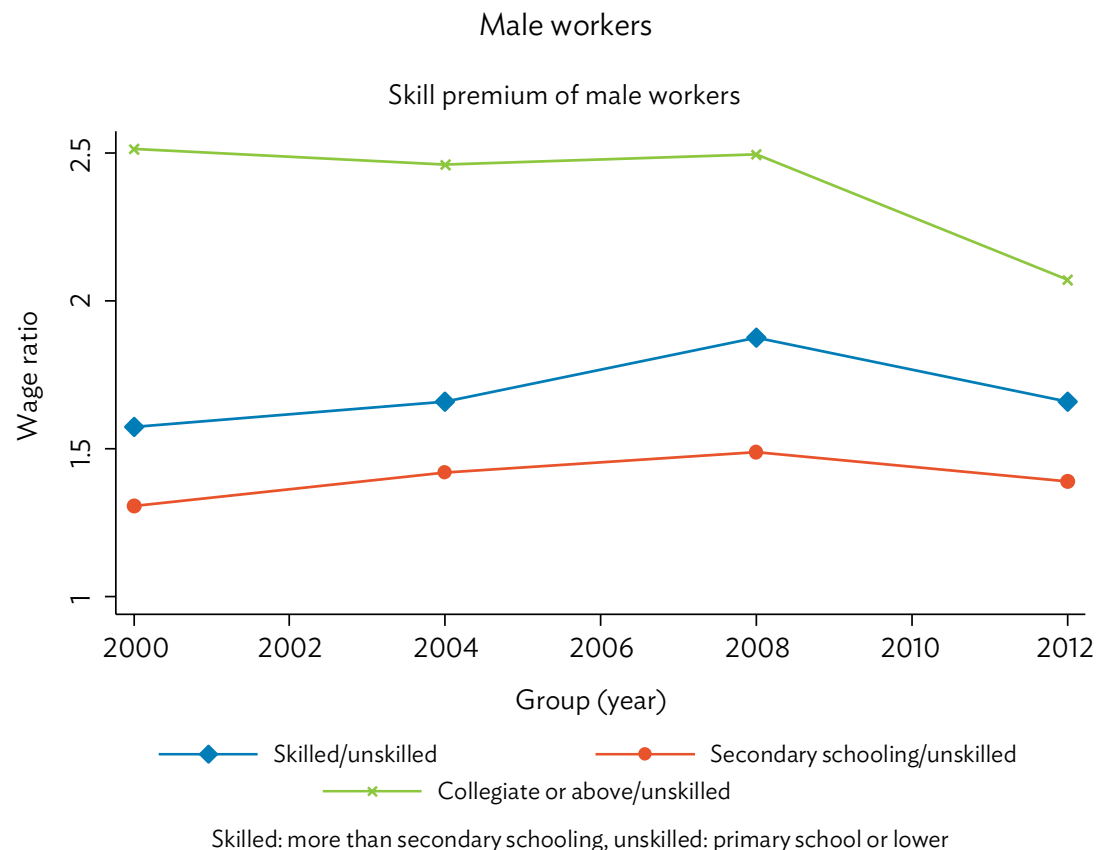

Skilled: more than secondary schooling, unskilled: primary school or lower

Female workers

Skill premium of female workers

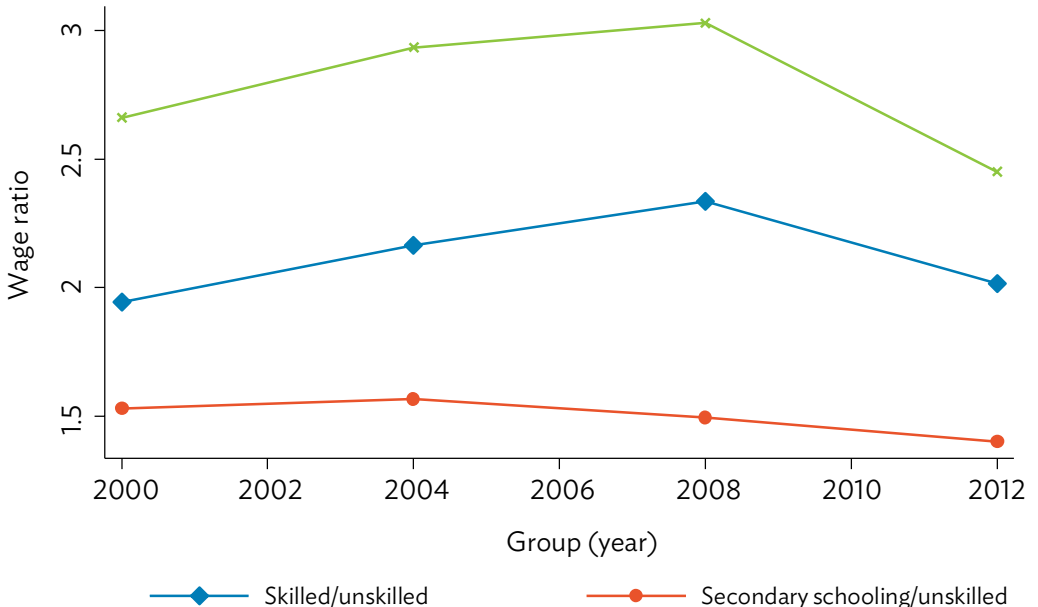

* Collegiate or above/unskilled

Source: Author. 
For both male and female workers in Sri Lanka, the proportion of the workers with tertiary education increased over the period 2000-2012, while the proportion of workers with primary education or lower declined. In addition, the workers who received secondary education occupied the largest proportion in labor market participation.

Figure 23: Labor Force Participation Rate in Sri Lanka

(\% of labor force, male)

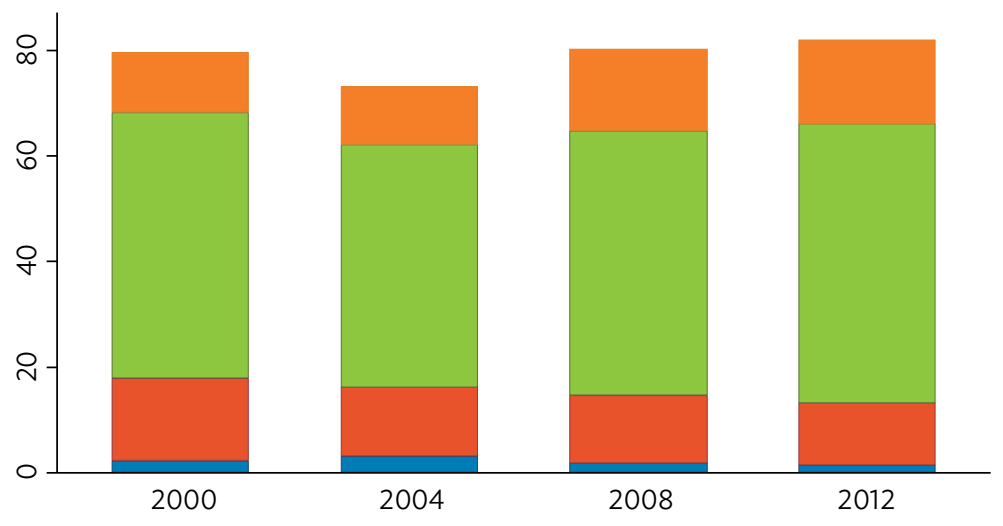

(\% of labor force, female)

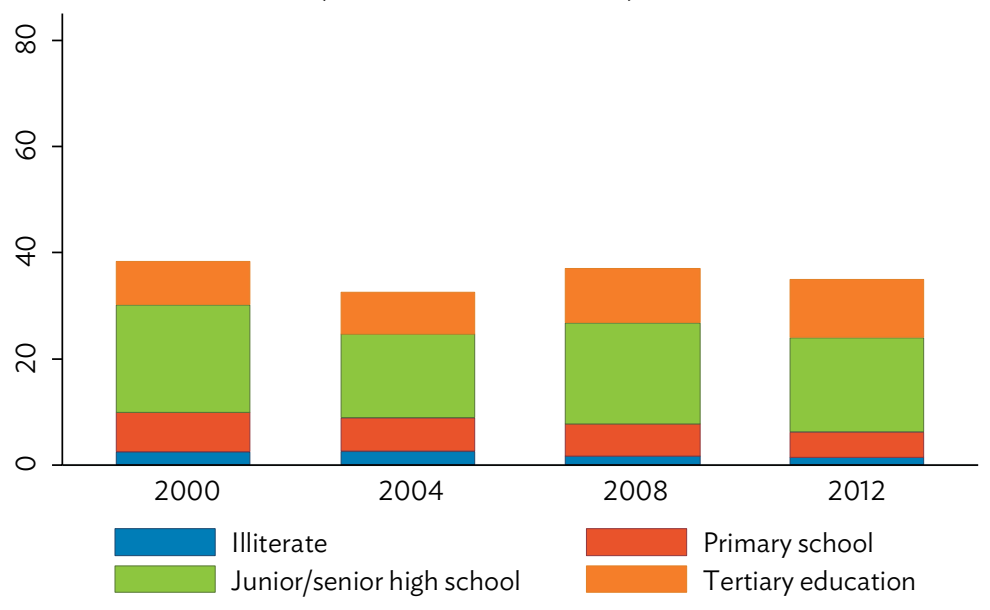

Note: Sample includes males and females 18-60 years old.

Source: Author. 


\section{Demand and Supply Analysis}

As in India, the changes in demand and supply of skilled labor in Sri Lanka were examined using the methodology of Katz and Murphy (1992). Wage and count sample were likewise constructed. The wage sample included full-time workers who were reported to work more than 30 hours per week at the primary job, but excluded unpaid family workers and anyone who did not have reported wage variable. Measures of working hours and wages were all unified in weekly terms. As in India, the full-time workers with zero weekly wage were treated as observations with missing wage variables. The count sample was constructed using all of the workers whose education level could be identified and restricted to the workers aged $15-60$.

The movement of relative supply and relative wage of various demographic groups was examined. The sample was divided into 32 categories by gender, four education levels, and four experience levels. The fixed weight of average employment share for 32 cells among all workers during the entire sample period was used to construct aggregate measures in the wage sample, while the count sample used the fixed weight of average relative wage for 32 cells.

Table 16 presents the summary statistics for waged workers in Sri Lanka. Over the sample period 2000-2012, the proportion of female workers was constant at around 33\% of the whole labor force. There was an increase in the workers with tertiary education from $16.4 \%$ in 2000 to $23.3 \%$ in 2012, while those with primary schooling or no education declined. Compared with India, Sri Lanka had a much smaller share of the workers with no education over the sample period. The distribution of workers by experience shows that the share of workers with more than 30 years of experience slightly increased over time.

\section{Table 16: Data Summary Statistics of Waged Workers in the Labor Force}

\begin{tabular}{|c|c|c|c|c|c|}
\hline \multirow[b]{2}{*}{ Variable } & \multirow[b]{2}{*}{ Category } & 2000 & 2004 & 2008 & 2012 \\
\hline & & \multicolumn{4}{|c|}{ (\% of total) } \\
\hline \multirow[t]{2}{*}{ Sex } & Male & 66.8 & 67.7 & 65.5 & 67.2 \\
\hline & Female & 33.2 & 32.3 & 34.5 & 32.8 \\
\hline \multirow[t]{4}{*}{ Education } & No education & 3.9 & 5.4 & 3.1 & 2.5 \\
\hline & Primary school & 19.7 & 18.2 & 15.9 & 14.1 \\
\hline & Secondary school & 60.0 & 58.5 & 59.0 & 60.1 \\
\hline & Tertiary education & 16.4 & 17.9 & 22.0 & 23.3 \\
\hline \multirow[t]{4}{*}{ Experience } & $\leq 9$ years & 22.7 & 21.1 & 19.8 & 18.5 \\
\hline & $10-20$ years of experience & 24.7 & 24.0 & 23.9 & 24.8 \\
\hline & $20-30$ years of experience & 24.0 & 24.5 & 23.7 & 23.8 \\
\hline & $>30$ years & 28.6 & 30.4 & 32.7 & 32.9 \\
\hline Sample Size & $\mathrm{N}$ & 21,039 & 31,196 & 25,021 & 20,190 \\
\hline
\end{tabular}

Source: Author. 


\section{Evolution of Relative Wage Change in Sri Lanka}

Changes in real weekly wages for full-time workers in Sri Lanka over the period 2000-2012 are shown in Table 17. Overall, the real wage decreased from 2000 to 2004, remained constant over the period 2004-2008, and turned around from 2008 to 2012.

The benefits were evenly distributed across female and male workers. The real wage of male workers increased by 22.2 from 2000 to 2012, while that of female workers increased by 19.5 over the same period.

However, the benefits were not evenly distributed across workers with different educational backgrounds. The workers with primary education gained the most over the period 20082012. The workers with secondary education are also beneficiaries over the whole period 2008-2012. They gained more in the recent period, 2008-2012, than in past periods. Additionally, the benefits of workers with secondary education in Sri Lanka were larger, compared with those in India. As the workers with secondary education and those with primary education comprised a large proportion in Sri Lanka, their wage gains significantly contributed to declining wage inequality in Figure 16.

Young workers also gained more compared with workers with more experience, implying that a reduction of experience premium can also be a driving force behind declining wage inequality.

\section{Table 17: Real Weekly Wage Changes for Full-Time Workers in Sri Lanka, 2000-2012}

\begin{tabular}{|l|c|c|c|c|}
\hline \multirow{2}{*}{ Group } & \multicolumn{4}{|c|}{ Changes in Log Average Real Monthly Wage (multiplied by 100) } \\
\cline { 2 - 5 } & $2000-2012$ & $2000-2004$ & $2004-2008$ & $2008-2012$ \\
\hline All & 21.3 & -8.3 & -0.86 & 30.5 \\
\hline By gender & & & & \\
\hline Male & 22.1 & -8.5 & -0.3 & 30.9 \\
\hline Female & 19.5 & -7.6 & -2.1 & 29.2 \\
\hline By education & & & -36.9 & \\
\hline No schooling & -31.9 & 3.5 & -18.8 & 54.8 \\
\hline Elementary & 21.9 & -14.0 & 2.3 & 29.3 \\
\hline Secondary school & 24.9 & -6.7 & 9.8 & 13.8 \\
\hline $\begin{array}{l}\text { University degree or } \\
\text { above }\end{array}$ & 13.3 & -10.3 & & \\
\hline By experience & & & -3.2 & 35.2 \\
\hline $1-10$ years & 25.8 & -6.2 & -5.4 & 33.1 \\
\hline $11-20$ years & 22.2 & -5.6 & 4.8 & 31.3 \\
\hline $21-30$ years & 26.7 & -9.4 & 0.3 & 24.0 \\
\hline$\geq 30$ years & 13.1 & -11.2 & & \\
\hline By gender and education & & & & \\
\hline Male workers & -52.8 & & & \\
\hline No schooling & & & & \\
\hline
\end{tabular}


Table 17 continued

\begin{tabular}{|c|c|c|c|c|}
\hline \multirow[b]{2}{*}{ Group } & \multicolumn{4}{|c|}{ Changes in Log Average Real Monthly Wage (multiplied by 100) } \\
\hline & 2000-2012 & $2000-2004$ & $2004-2008$ & 2008-2012 \\
\hline Elementary & 21.1 & -16.9 & -18.9 & 56.9 \\
\hline Secondary school & 26.2 & -4.9 & 3.3 & 27.8 \\
\hline $\begin{array}{l}\text { University degree } \\
\text { or above }\end{array}$ & 12.3 & -16.9 & 12.0 & 17.2 \\
\hline \multicolumn{5}{|l|}{ Female workers } \\
\hline No schooling & -9.0 & -2.4 & -6.9 & 0.3 \\
\hline Elementary & 23.7 & -7.8 & -18.6 & 50.1 \\
\hline Secondary school & 21.1 & -11.9 & -0.9 & 33.9 \\
\hline $\begin{array}{l}\text { University degree } \\
\text { or above }\end{array}$ & 14.7 & -0.9 & 6.6 & 9.0 \\
\hline
\end{tabular}

Notes: Numbers represent log changes in average weekly wages. Average weekly wages for full-time workers in each of 32 sex education-experience cells were computed in each year. Average wages for broader groups in each year are weighted averages of these cell averages using a fixed set of weights (the average employment share of the cell for entire period). All earnings are deflated by the consumer price index each year.

Source: Author.

Table 18: Relative Monthly Supply Changes of Employed Workers in Sri Lanka, 2000-2012

\begin{tabular}{|c|c|c|c|c|}
\hline \multirow[b]{2}{*}{ Group } & \multicolumn{4}{|c|}{$\begin{array}{l}\text { Changes in Log Share of Aggregate Labor Input } \\
\text { (multiplied by 100) }\end{array}$} \\
\hline & 2000-2012 & 2000-2004 & 2004-2008 & 2008-2012 \\
\hline \multicolumn{5}{|l|}{ By gender } \\
\hline Men & -2.5 & 1.2 & -4.1 & 0.3 \\
\hline Women & 7.4 & -3.8 & 12.0 & -0.8 \\
\hline \multicolumn{5}{|l|}{ By education } \\
\hline No schooling & -43.8 & 34.2 & -57.9 & -20.1 \\
\hline Primary school & -51.9 & -10.6 & -18.9 & -22.4 \\
\hline Secondary school & -14.9 & -3.3 & -3.0 & -8.6 \\
\hline University Degree & 44.4 & 8.9 & 16.5 & 18.9 \\
\hline \multicolumn{5}{|l|}{ By experience } \\
\hline $1-10$ years & 1.8 & -6.6 & -0.2 & 8.7 \\
\hline $11-20$ years & 2.5 & -1.8 & -1.4 & 5.7 \\
\hline $21-30$ years & -3.6 & 3.9 & -4.4 & -3.1 \\
\hline$\geq 30$ years & -0.5 & 2.8 & 5.6 & -9.0 \\
\hline \multicolumn{5}{|c|}{ By gender and education } \\
\hline \multicolumn{5}{|c|}{ Male workers } \\
\hline No schooling & -38.9 & 47.9 & -66.4 & -20.5 \\
\hline Elementary school & -53.7 & -11.3 & -20.9 & -21.5 \\
\hline
\end{tabular}


Table 18 continued

\begin{tabular}{|c|c|c|c|c|}
\hline \multirow{2}{*}{ Group } & \multicolumn{4}{|c|}{ Changes in Log Share of Aggregate Labor Input } \\
(multiplied by 100) \\
\hline Secondary school & $2000-2012$ & $2000-2004$ & $2004-2008$ & $2008-2012$ \\
\hline University Degree & -10.5 & -0.5 & -6.7 & -3.3 \\
\hline Female workers & 35.8 & 8.4 & 13.2 & 14.3 \\
\hline No schooling & & & & \\
\hline Elementary school & -50.4 & 13.1 & -44.1 & -19.5 \\
\hline Secondary school & -46.0 & -8.2 & -12.6 & -25.2 \\
\hline University Degree & -33.5 & -14.9 & 11.8 & -30.4 \\
\hline
\end{tabular}

Source: Author.

\section{Evolution of Relative Supply Changes in Sri Lanka}

Table 18 shows the relative supply changes in employed workers in Sri Lanka over the sample period 2000-2012, and suggests supply-side changes as the possible source for the evolution of relative weekly wage in Table 17. The evolution of relative supply changes by education level implies that the declining wage inequality could have resulted from an increase in the relative supply of more skilled workers and a decrease in the relative supply of middle-skilled workers.

To be specific, the relative supply of workers with university degree sharply increased for the whole period, while that of workers with primary education or lower significantly decreased over the same period. In addition, there was a decline in the relative supply of workers with secondary education. This pattern also appears in the analysis of relative supply changes for both female and male workers. Furthermore, the increase in the relative supply of skilled workers had been accelerated.

\section{Demand Shift toward Skilled Workers}

To further examine the demand and supply factor on wage inequality, the supply-demand analysis suggested by Katz and Murphy (1992) was conducted using 32 labor groups in the sample. The inner products of the changes in these measures of wages and supplies between each pair of these 4 years were calculated.

As presented in Table 19, the results for the supply-demand analysis in Sri Lanka show overall negative signs, indicating that supply and demand mechanism determined wage in the market for most of the time except early 2000 to 2009 . The early 2000 to 2009 should be considered as a depression period in Sri Lanka due to tsunami damages in 2004.

Sri Lanka experienced declining wage inequality from 2000 to 2012. The supply-demand analysis reports demand and supply of skilled workers as the major force in Sri Lanka's labor market. To conclude, the increase in supply of skilled labor may have caused the declining skill premium and wage inequality in Sri Lanka. 
Table 19: Inner Products of Changes in Wages with Changes in Supplies

\begin{tabular}{|l|c|c|c|}
\hline \multirow{2}{*}{ End period } & \multicolumn{3}{|c|}{ Starting Period } \\
\cline { 2 - 4 } & 2000 & 2004 & 2008 \\
\hline 2004 & 0.0004 & - & - \\
\hline 2008 & 0.0007 & 0.0018 & -0.0084 \\
\hline
\end{tabular}

- = data not available.

Notes: Numbers represent inner products between changes in relative wages and change in relative supplies of 32 cells. Each inner product is calculated using changes across column period and row period. Relative wage measure is constructed from the sample of full-time workers in the formal sector while relative supply is calculated from the sample of workers in the formal sector.

Source: Author.

\section{Bangladesh}

In the investigation of the change in demand and supply of skilled workers in Bangladesh, the focus was on whether there has been greater employment of skilled workers. If so, the change was driven mostly by increased demand from within industries or between industries. The demand shift within each industry, rather than between industries, was attributed to technological changes that favor more skilled workers.

Two sets of labor force surveys from Bangladesh in 2006 and 2010 were employed, which were more or less consistent in terms of sample size and variables. Each round had around 180,000 observations that were representative of Bangladesh economy. ${ }^{28}$ The survey also employed two-stage clustered sampling and post-estimated survey weight for researchers to acquire accurate estimates.

Bangladesh labor market has a significant size of informal economy. Even measuring the accurate size of the informal sector was difficult as many of those sector-related variables have missing values. One big caveat of Bangladesh labor force survey data was that wage variable has lots of missing values, especially in the 2006 survey. Therefore, wage information was not utilized in the analysis.

Figure 24 shows the labor force participation and skill composition of workers in Bangladesh by area and gender over time. The labor market was marked by a significantly higher labor force participation rates in urban area than in rural area over the period. The overall labor force participation of male workers declined, while that of female workers sharply increased from 2006 to 2010.

There were also some changes in skill composition. Surprisingly, the share of workers with tertiary education declined among urban male workers, while that of workers with secondary schooling increased at the same time. Among female workers, there was a sharp increase in the share of workers with secondary schooling in the labor market.

${ }^{28}$ Each round of the Bangladesh labor force survey different industry codes. For analysis of pooled data, one unified two-digit industry code was constructed. 


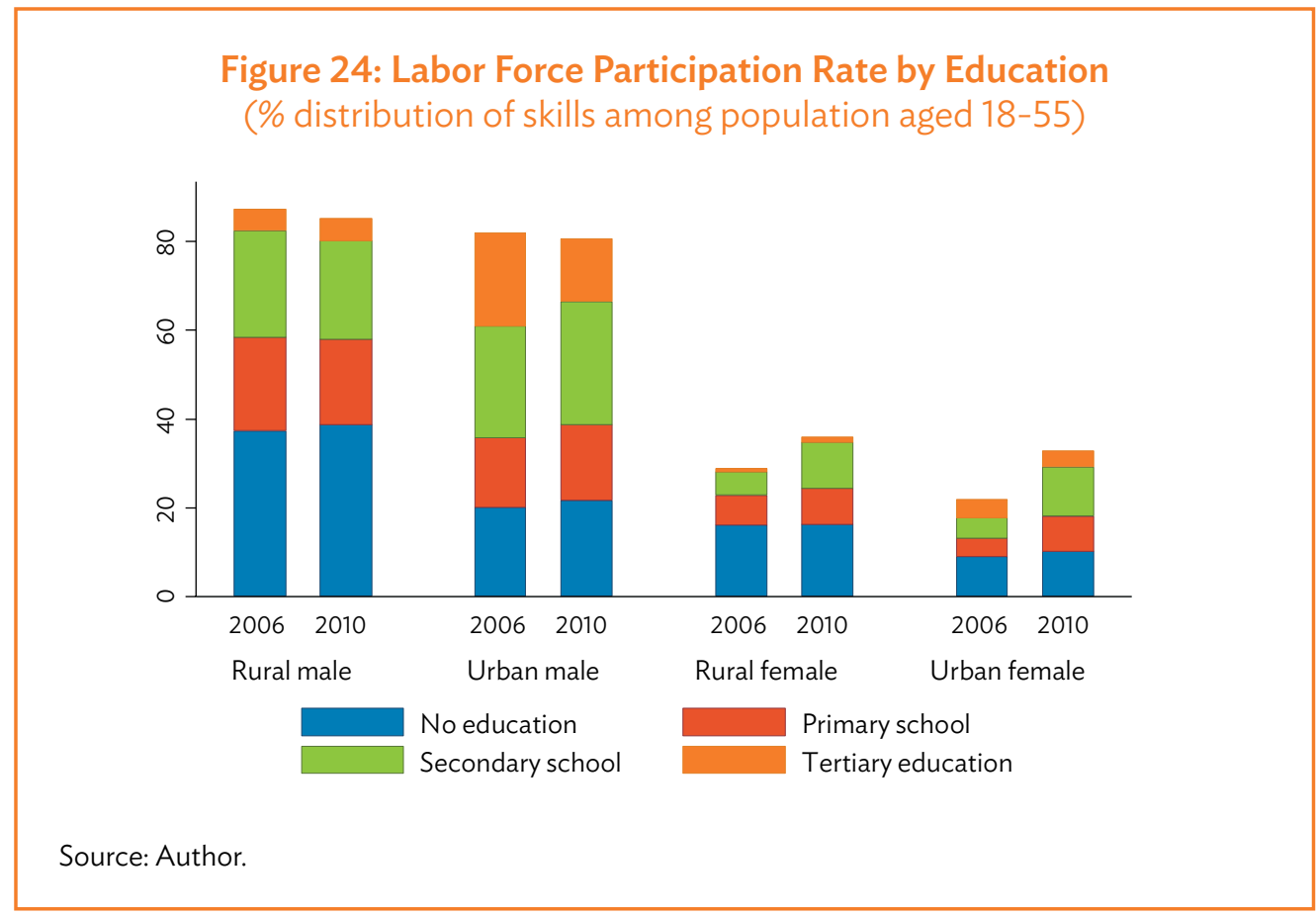

Table 20 presents the characteristics of labor force in Bangladesh. According to the data, male workers accounted for more than 70\% of the workforce in 2006 and 2010. However, the proportion of male workers slightly declined from 2006 to 2010 in both rural and urban Bangladesh.

One should note distinctions in educational distribution of workers across regions. In rural Bangladesh, more than $40 \%$ of the workers did not receive any formal education, which is lower than 30\% in urban Bangladesh. The workers with tertiary education accounted for around $5 \%$ in rural area in both 2000 and 2006, while the ones in urban area accounted for $15.9 \%$ in 2010 , a decrease from $24.1 \%$ in 2006 . The sudden drop of the proportion of workers with tertiary education in urban Bangladesh should be studied further.

In 2010, the proportion of workers in management or professional occupation was very small: only around $4 \%$ in rural Bangladesh and more than $10 \%$ in urban Bangladesh. Attention should be placed on the slight decrease in workers in professional occupation. Majority of workers belong to manual workers in both rural and urban areas. However, in urban area, workers in clerical jobs are much larger (around 20\%), compared with those in rural area (around 17\%). 
Table 20: Data Summary Statistics of Waged Workers in the Labor Force

\begin{tabular}{|c|c|c|c|c|c|}
\hline \multirow[b]{3}{*}{ Variable } & \multirow[b]{3}{*}{ Category } & \multicolumn{2}{|c|}{ Rural Area } & \multicolumn{2}{|c|}{ Urban Area } \\
\hline & & 2006 & 2010 & 2006 & 2010 \\
\hline & & \multicolumn{4}{|c|}{ (\% of total) } \\
\hline \multirow[t]{2}{*}{ Sex } & Male & 75.1 & 70.0 & 79.2 & 71.2 \\
\hline & Female & 24.9 & 30.0 & 20.8 & 28.8 \\
\hline \multirow[t]{4}{*}{ Education } & No education & 46.0 & 45.5 & 28.0 & 28.1 \\
\hline & Primary education & 24.0 & 22.5 & 19.2 & 22.0 \\
\hline & Secondary education & 25.2 & 26.9 & 28.7 & 34.0 \\
\hline & Tertiary education & 4.8 & 5.1 & 24.1 & 15.9 \\
\hline \multirow[t]{3}{*}{ Occupation } & Management, professionals & 3.7 & 4.6 & 13.3 & 10.3 \\
\hline & Service and clerical workers & 16.4 & 18.5 & 36.7 & 23.8 \\
\hline & Manual workers & 79.9 & 77.0 & 50.0 & 65.9 \\
\hline Sample Size & $\mathrm{N}$ & 37,608 & 54,592 & 19,236 & 13,869 \\
\hline
\end{tabular}

Source: Author.

The fixed-coefficient manpower requirements index is widely used to measure the effect of between-sector demand shifts on relative labor demand. The index calculates the percentage change in the demand for a demographic group as the weighted average of percentage employment growth by industry (Freeman 1975 and 1980). The industrial employment distribution by demographic group in a base period serves as weights. This measurement of demand shift proved to be appropriate, although it has a tendency to understate relative demand shifts of groups with increase in relative wages.

One unified 2-digit industry code for analysis was used. Occupation codes were aggregated into three general categories following the existing literature. The first category included professional workers and management workers, the second category included service and clerical workers, and the third category included manual workers and production workers.

Female workers of high education level are still not very representative across all industries and occupations. To prevent any bias coming from measurement errors of dealing with a small sample of female workers, the focus was on male workers only.

According to Katz and Murphy (1992), the overall (industry-occupation) demand shift index for group $k, \Delta X_{k}^{d}$, as the index given in the following equation:

$$
\Delta X_{k}^{d}=\frac{\Delta D_{k}}{E_{k}}=\sum_{j}\left(\frac{E_{j k}}{E_{k}}\right)\left(\frac{\Delta E_{j}}{E_{j}}\right)=\frac{\sum_{j} \propto_{j k} \Delta E_{j}}{E_{k}}
$$

where index of demand shift for group $k$ is measured relative to base employment of group $k$ in efficiency units, $E_{k} . \Delta E_{j}$ measures total labor input as efficiency unit in cell $j$, where $j$ indexes 54 industry-occupation cells. $\alpha_{j k}=\left(\frac{E_{j k}}{E_{J}}\right)$ is group $k$ 's average share of total employment in efficiency units in cell $j$ during the sample period. Thus, the average share of total employment is used in cell $j$ of group $k$ over the sample period as our measure of $\propto_{j k}$, and the average share of group $k$ in total employment over the sample period as the measure of $E_{k}$. To make it easy to calculate, we normalize equation (1), so that total 
employment in efficiency units in each year sums to one. Group $k$ is divided by workers' job status (informal/formal) and three skill levels: no education, junior high education, and senior high education or higher. Since the share of workers who acquired tertiary education is very low in 1990 s, tertiary education category is merged with senior high school category to decrease bias resulting from measurement error.

This index is also decomposed into between- and within-industry components. The between-industry demand shift index for group $k, \Delta X_{k}^{b}$ is given by the index in equation (1) when $j$ refers to 18 industries. Within-industry demand shift index for $k, \Delta X_{k}^{w}$ is defined as the difference between the overall demand shift index and the between-industry demand shift index (i.e., $\Delta X_{k}^{w}=\Delta X_{k}^{d}-\Delta X_{k}^{b}$ ). These within-industry demand shifts reflect shifts in employment within industries.

Existing literature defines informal employment as workers who have no written contract (ADB 2010). The survey data has a variable regarding their working contract; however, many observations have missing values. Therefore, formal and informal are categorize by sector rather than by the existence of working contract. Government and private formal firms are categorized into formal sector, while sole proprietorship and household production are categorized into informal sector.

Total employment declined partly due to negative macroeconomic shocks such as global financial crisis (Table 21). There is no demand shift toward more skilled workers in Bangladesh yet (Table 21). Rather, there is a trend of hiring unskilled workers as the size of industries with low-skilled workers increases. The between-industry demand for more skilled workers decreased, while that for less-skilled workers increased in both formal and informal sectors.

Both formal and informal sectors experienced a sharp decrease in within-industry demand for skilled workers. However, in the formal sector, the magnitude of decrease in demand for more skilled workers was smaller than that for less-skilled workers. Overall, there is no evidence that Bangladesh experienced any demand shift toward more skilled workers.

Table 21: Changes in Log Relative Demand for Male Workers (multiplied by 100)

\begin{tabular}{|c|c|c|c|}
\hline & Between Industry & Within Industry & Overall \\
\hline Formal workers & & & \\
\hline No education & 6.67 & -23.74 & -17.07 \\
\hline Primary education & 4.20 & -16.62 & -12.42 \\
\hline Secondary schooling or higher & -3.76 & -7.02 & -10.77 \\
\hline Informal workers & & & \\
\hline No education & 0.28 & -11.90 & -11.62 \\
\hline Primary education & 1.19 & -12.39 & -11.20 \\
\hline Secondary schooling or higher & -0.15 & -10.79 & -10.94 \\
\hline
\end{tabular}

Source: Author. 


\section{Indonesia}

Recent changes in demand and supply of skilled workers in Indonesia were analyzed by extending the work of Lee and Wie (2015a). The data sets now cover the period between 1990 and $2013 . .^{29}$

\section{Wage Inequality in Indonesia}

Indonesia experienced a decline in wage inequality until 2003 and a sharp increase thereafter (Lee and Wie 2015a). The increasing trend in wage inequality intensified during the recent period, 2010-2013 (Figure 25). The most-skilled group (proxied here by the 10th percentile) benefited the most from economic growth over the recent period. In contrast, the median and least-skilled groups experienced a decline in real wages.

During the recent period, differences in trends in wage inequality across regions emerged, especially for the least-skilled group. Real wages of the least-skilled group showed a decreasing trend in urban Indonesia, but an increasing trend in rural Indonesia. Those of the median groups moved in a similar manner, but less intensively.

Differences between rural and urban Indonesia are more prominent in Figure 26 that shows trends in Gini coefficients of Indonesia from 1990 to 2013. From 2010 to 2013, Gini coefficients in rural areas decreased, in contrast to the increase in urban areas and Indonesia as a whole. This indicates that, despite the improvement in wage inequality in rural area, the equality deteriorated in Indonesia over the recent period.

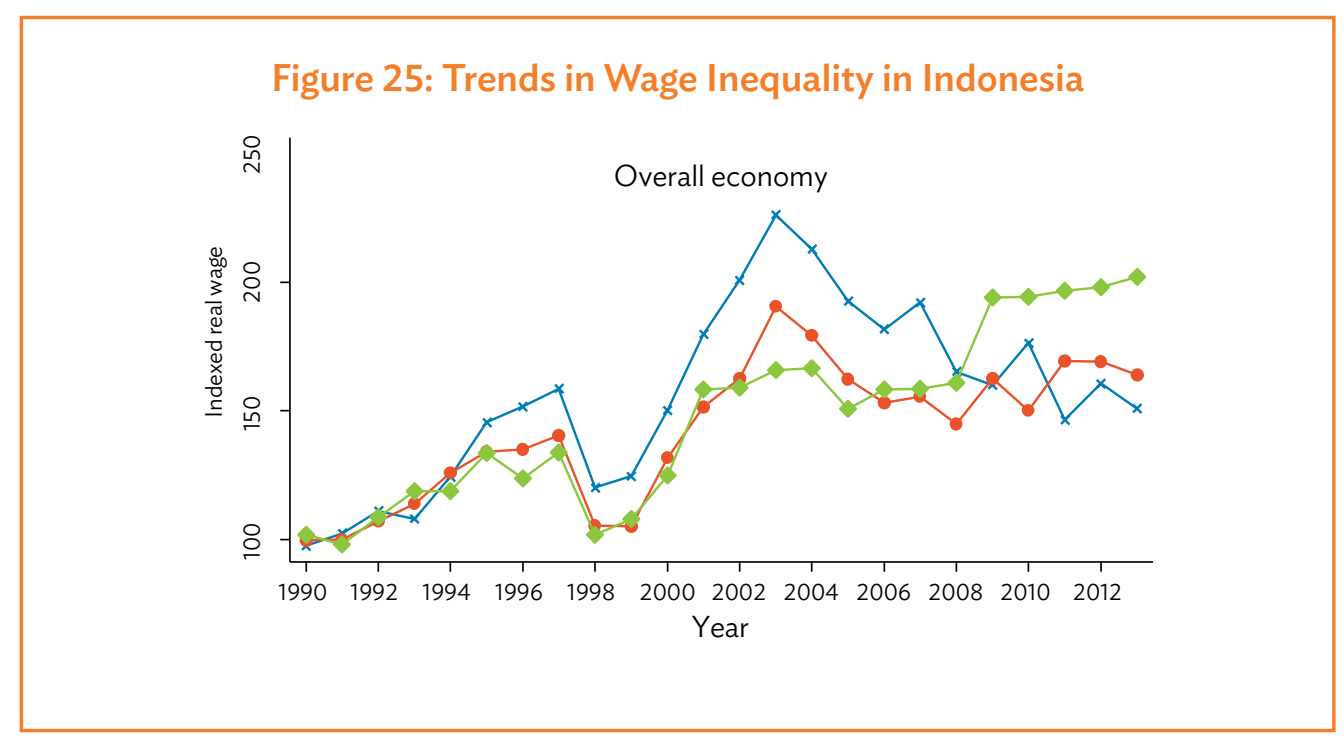

continued on next page

\footnotetext{
29 Please refer to Lee and Wie (2015a) for details. An analysis in this paper is an updated investigation of Lee and Wie (2015a) by adding recent years 2011, 2012, and 2013.
} 

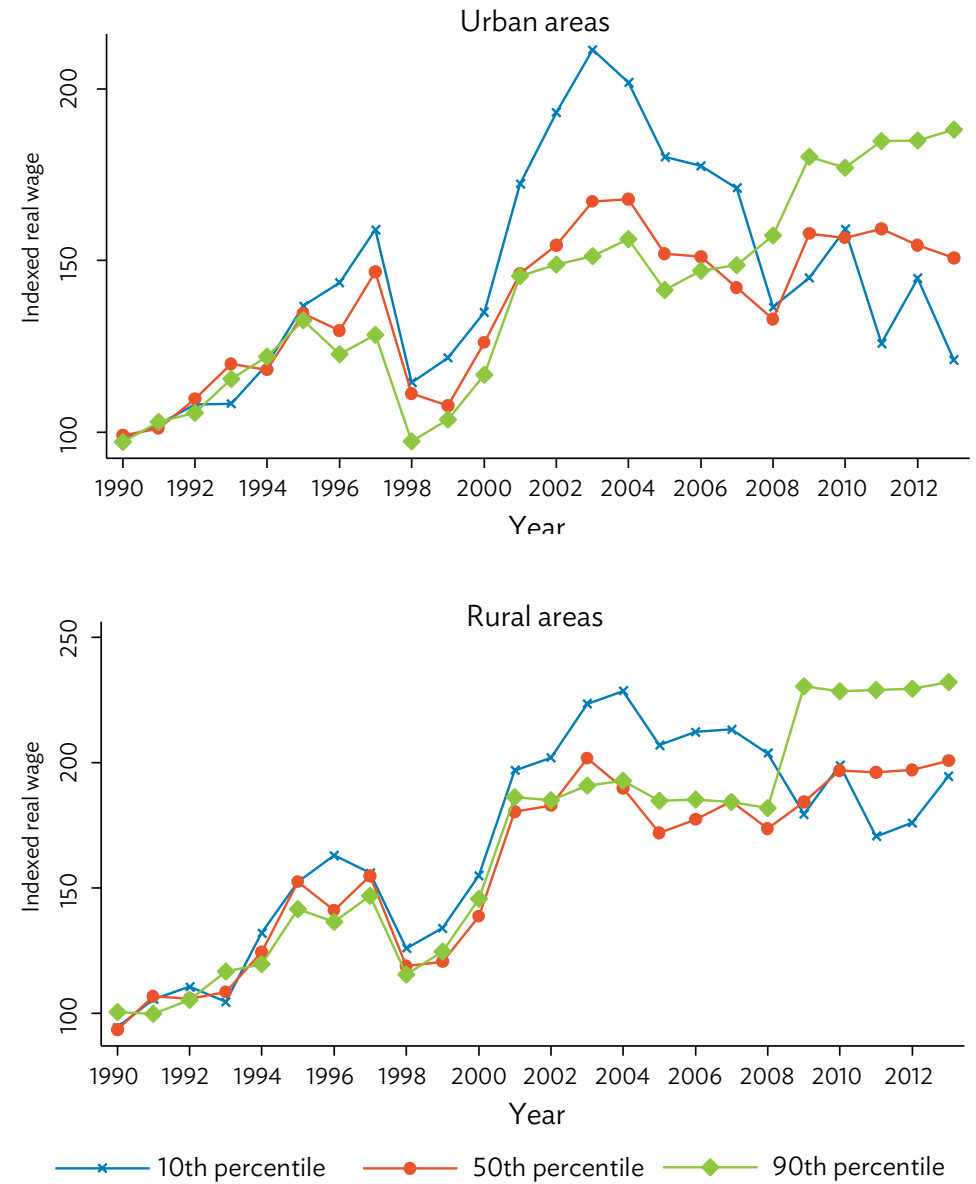

Note: Samples include paid workers.

Source: Author.

Figure 26: Gini Coefficients in Indonesia

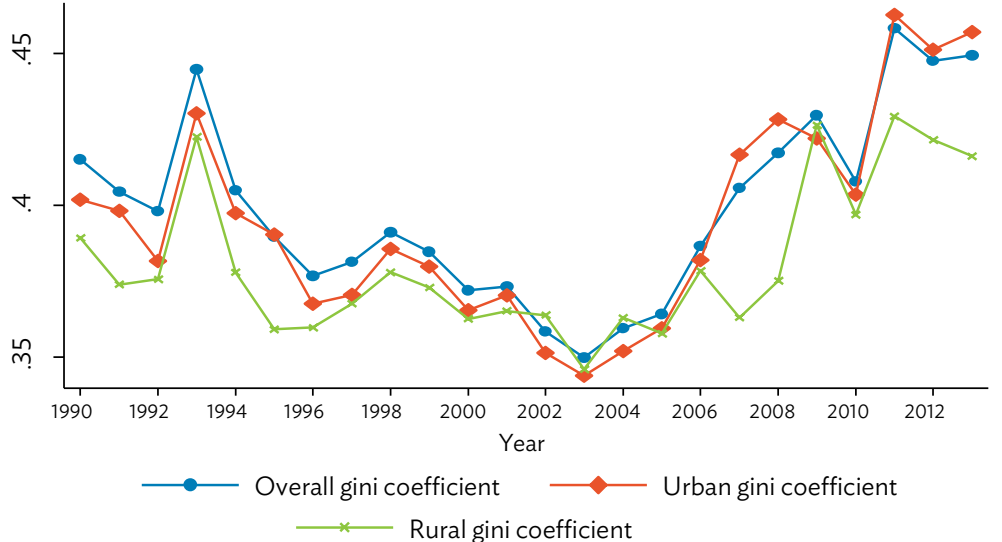

Source: Author. 


\section{Skill Premium Trends}

As suggested in Lee and Wie (2015a), in Indonesia, the recent change in wage inequality is related to the change in skilled premiums. Premiums to high school and college in urban Indonesia significantly increased after 2003. In both urban and rural areas, skill premiums decreased until 2008, and then suddenly rose in 2009. After 2009, all of the premium indicators remained high across the regions. These trends seem to imply an increase in the skill premium as a source of rising wage inequality.

\section{Figure 27: Skill Premium in Indonesia}

Urban areas
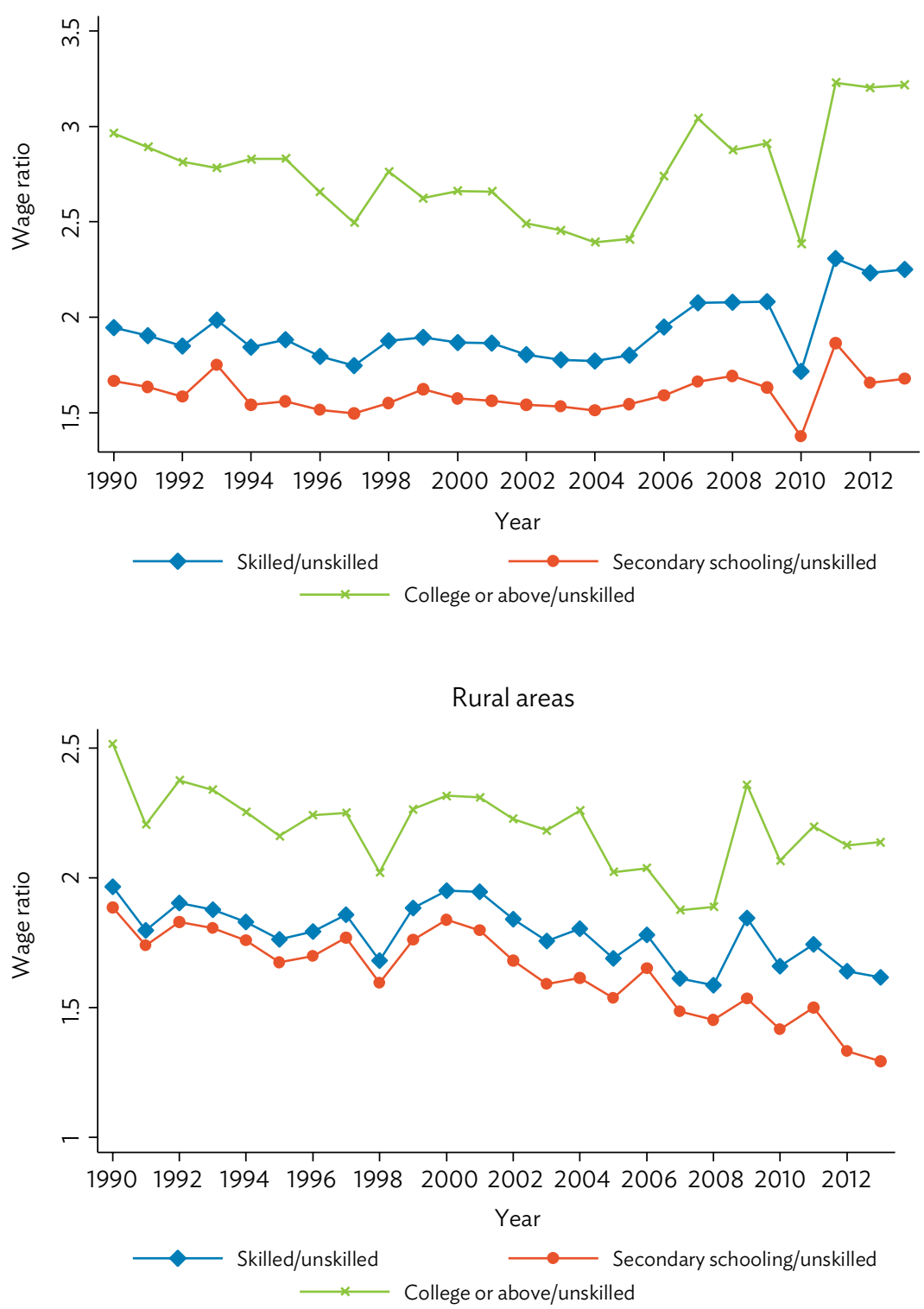

Source: Author. 
Residual Wage Inequality Implications

As in India, using the regression in Lee and Wie (2015a), residual equality was calculated across regions and gender to examine within-group wage inequality in Indonesia. Figure 28 shows the increases in residual wage inequality in both region and for both males and females from 2004 to 2013. This implies that high-skilled workers enjoyed far more gains compared with low-skilled workers during recent periods (Lee and Wie 2015a).

Figure 28: Residual Wage Inequality in Indonesia
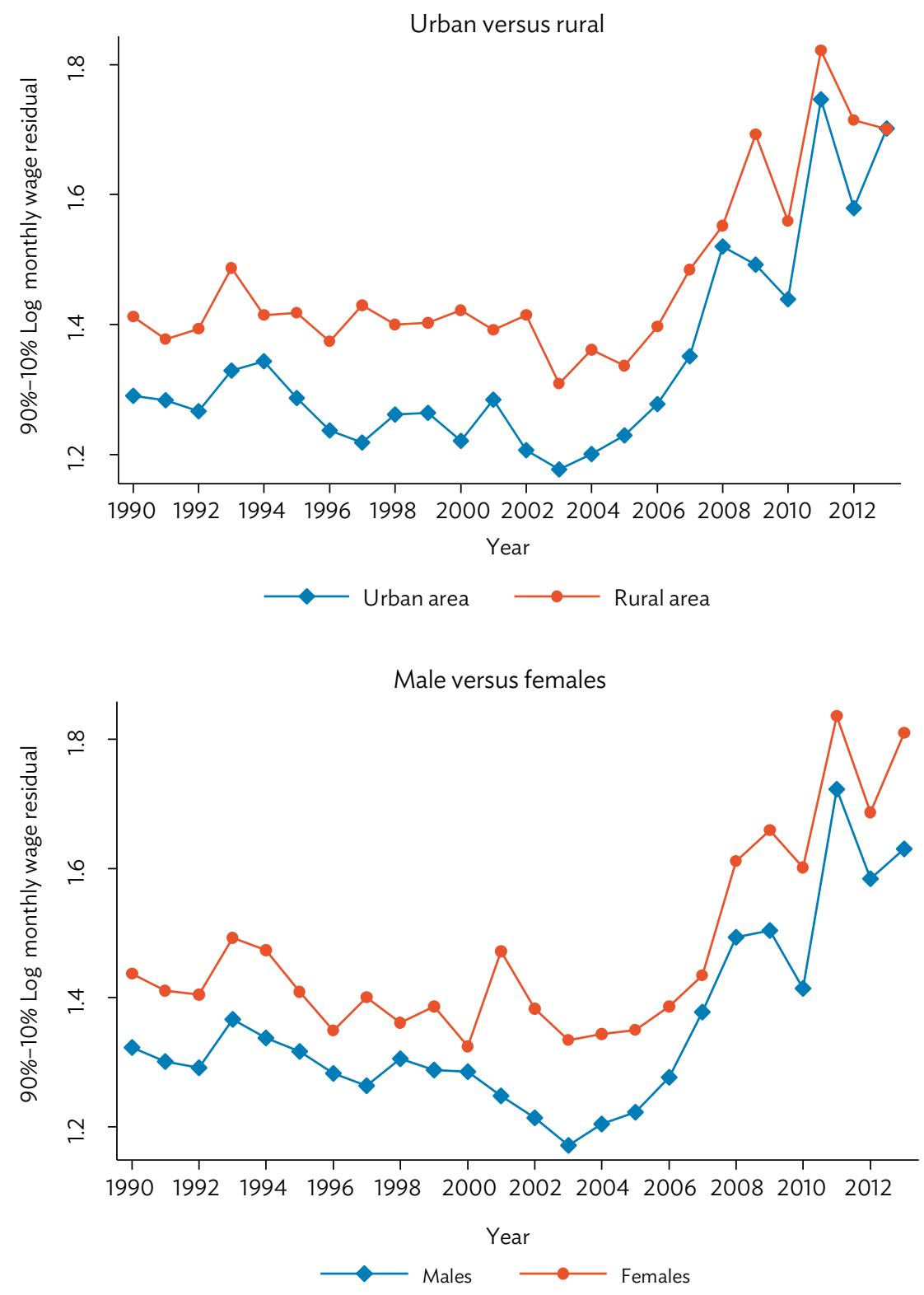

Source: Author. 


\section{Demand and Supply Analysis}

As mentioned earlier, the supply and demand analysis was conducted by adding the years 2011, 2012, and 2013 to the methodology used by Lee and Wie (2015a). The methodology of Katz and Murphy (1992) was likewise used. Table 22 presents the summary statistics of Indonesian labor market over the period 1990-2013. As suggested in Lee and Wie (2015a), a significant increase in younger and more education workers in the recent years is one of the distinctive features of the labor market.

Table 22: Data Summary Statistics of Workers in the Labor Force, 1990-2013 (\% of total)

\begin{tabular}{|c|c|c|c|c|c|}
\hline Variable & Category & 1990-1995 & 1996-2002 & $2002-2008$ & $2008-2013$ \\
\hline \multirow[t]{2}{*}{ Region } & Urban & 50.8 & 57.7 & 68.9 & 68.6 \\
\hline & Rural & 49.2 & 42.3 & 31.1 & 31.4 \\
\hline \multirow[t]{2}{*}{ Sex } & Male & 70.5 & 68.9 & 68.8 & 65.3 \\
\hline & Female & 29.5 & 31.1 & 31.2 & 34.7 \\
\hline \multirow[t]{4}{*}{ Education } & Elementary degree or less & 50.6 & 41.0 & 25.3 & 22.6 \\
\hline & Junior high school & 13.2 & 15.2 & 18.8 & 17.1 \\
\hline & Senior high school & 28.9 & 32.7 & 39.3 & 38.8 \\
\hline & Tertiary education & 7.4 & 11.2 & 16.7 & 21.5 \\
\hline \multirow[t]{4}{*}{ Experience } & $\leq$ years & 26.9 & 27.6 & 31.1 & 32.4 \\
\hline & $10-20$ years of experience & 30.8 & 30.7 & 32.4 & 30.6 \\
\hline & 20-30 years of experience & 22.6 & 22.5 & 21.5 & 22.4 \\
\hline & $>30$ years & 19.7 & 19.2 & 15.0 & 14.6 \\
\hline Sample size & $\mathrm{N}$ & 331,262 & 174,669 & 197,194 & 228,111 \\
\hline
\end{tabular}

Note: Sample includes all formal sector employed workers.

Source: National Labor Force Survey (SAKERNAS).

\section{Evolution of Relative Wages in Indonesia}

Changes in real monthly wages for full-time workers in Indonesia over the period 19902013 are shown in Table 23. As reported in Lee and Wie (2015a), over the whole sample period, the real wage increased. Females and less-educated workers gained more than other groups, despite their huge declines during the period 2002-2008.

From 2008 to 2013, workers with primary education gained the most, followed by workers with university degree or above. The benefits of other groups, including workers with junior high and senior high education, are much smaller. Among the skilled groups, the leastskilled group benefited the most, followed by workers with 21-30 years of experience. 
Table 23: Real Monthly Wage Changes for Full-Time Workers in Indonesia, 1990-2013

\begin{tabular}{|c|c|c|c|c|c|}
\hline \multirow[b]{2}{*}{ Group } & \multicolumn{5}{|c|}{ Changes in Log Average Real Monthly Wage (multiplied by 100) } \\
\hline & 1990-2013 & 1990-1996 & 1996-2002 & $2002-2008$ & 2008-2013 \\
\hline All & 44.1 & 29.2 & 12.7 & -6.0 & 8.2 \\
\hline \multicolumn{6}{|l|}{ By gender } \\
\hline Male & 37.3 & 27.0 & 11.3 & -8.2 & 7.2 \\
\hline Female & 58.8 & 34.2 & 15.7 & -1.4 & 10.2 \\
\hline \multicolumn{6}{|l|}{ By education } \\
\hline $\begin{array}{l}\text { Elementary degree } \\
\text { or less }\end{array}$ & 57.1 & 33.6 & 14.6 & -3.5 & 12.5 \\
\hline Junior high school & 26.9 & 23.9 & 11.03 & -10.6 & 2.6 \\
\hline Senior high school & 25.2 & 23.8 & 10.4 & -10.1 & 1.0 \\
\hline University degree & 35.6 & 20.4 & 7.4 & -1.6 & 9.4 \\
\hline \multicolumn{6}{|l|}{ Experience } \\
\hline $1-10$ years & 38.7 & 33.1 & 9.7 & -13.0 & 8.8 \\
\hline $11-20$ years & 33.9 & 24.7 & 11.2 & -9.4 & 4.5 \\
\hline $21-30$ years & 35.2 & 24.3 & 11.7 & -8.9 & 8.1 \\
\hline$\geq 30$ years & 42.0 & 28.0 & 12.0 & -2.8 & 4.8 \\
\hline \multicolumn{6}{|l|}{ Region } \\
\hline Urban & 25.2 & 24.6 & 9.9 & -11.0 & 1.7 \\
\hline Rural & 58.7 & 32.9 & 14.9 & -2.1 & 13.1 \\
\hline
\end{tabular}

Notes: Numbers represent log changes in average monthly wages using SAKERNAS for 1990-2013. Average monthly wages for full-time workers in each of 64 sex education region-experience cells were computed in each year. Average wages for broader groups in each year are weighted averages of these cell averages using a fixed set of weights (the average employment share of the cell for entire period). All earnings are deflated by the consumer price index each year.

Source: Author.

\section{Evolution of Relative Supplies in Indonesia}

Table 24 shows the relative supply changes for employed workers over the period 19902013. Over the whole period, the relative supply of female labor increased significantly, implying that the supply-side change could not explain the increase in relative wage of female workers.

The evolution of relative supply changes by education level suggests that the supply and demand analysis cannot fully explain the change in wage structure of Indonesia. While the declining relative supply of the least-educated workers during the recent period 20082013 can explain the increase in their real wages, the increasing relative supply of workers with university diploma or higher may imply demand shift favoring educated and skilled workers. 
Table 24: Relative Monthly Supply Changes of Employed Workers, 1990-2013

\begin{tabular}{|l|c|c|c|c|c|}
\hline \multirow{2}{*}{ Group } & \multicolumn{4}{|c|}{ Changes in Log Share of Aggregate Labor Input (multiplied by 100) } \\
\hline Gender & $1990-2013$ & $1990-1996$ & $1996-2002$ & $2002-2008$ & $2008-2013$ \\
\hline Men & & & & & \\
\hline Women & -6.9 & -0.5 & 0.0 & -4.8 & -1.6 \\
\hline Education & 19.9 & 1.7 & -0.0 & 14.0 & 4.2 \\
\hline Primary schooling or less & -80.9 & -25.4 & -17.0 & -16.7 & -21.7 \\
\hline Junior high school & 29.8 & 17.0 & 22.3 & 4.9 & -14.4 \\
\hline Senior high school & 59.8 & 34.7 & 6.2 & 8.0 & 11.0 \\
\hline University degree & 125.7 & 50.9 & 21.0 & 22.2 & 31.6 \\
\hline Experience & & & & & \\
\hline $1-10$ years & 7.0 & 10.1 & -12.3 & 10.2 & -1.1 \\
\hline $11-20$ years & -4.1 & 0.8 & 9.7 & -11.8 & -2.8 \\
\hline $21-30$ years & -0.5 & 1.9 & -3.6 & -4.6 & 5.9 \\
\hline$\geq 30$ years & -26.0 & -10.6 & 0.1 & -5.8 & -9.7 \\
\hline Region & & & & & \\
\hline Urban & 50.9 & 24.4 & 14.6 & -0.5 & 12.3 \\
\hline Rural & -51.1 & -18.2 & -15.7 & 0.6 & -17.7 \\
\hline
\end{tabular}

Notes: Numbers represent log changes in each group's share of total monthly labor supply measured in efficiency units (annual working hours times the average relative wage of the group for the sample period) using SAKERNAS. Supply measures include all workers in the count sample described above.

Source: Author.

\section{Demand Shift toward Skilled Workers}

As in Lee and Wie (2015a), the existence of demand factor was examined using the supplydemand analysis suggested by Katz and Murphy (1992). The results for the analysis (Table 25) present positive signs in recent periods, indicating that there is demand shift favoring skilled workers in the labor market in Indonesia.

Table 25: Inner Products of Changes in Wages with Changes in Supplies

\begin{tabular}{|l|c|c|c|c|}
\hline \multirow{2}{*}{ 5-Year Centered Interval } & \multicolumn{3}{|c|}{ 5-Year Centered Interval } \\
\cline { 2 - 5 } & $1990-1994$ & $1995-1999$ & 2000-2004 & 2005-2009 \\
\hline $1995-1999$ & -0.0112 & & & \\
\hline $2000-2004$ & -0.0402 & -0.0069 & & \\
\hline $2005-2009$ & -0.0300 & -0.0002 & 0.0022 & 0.0048 \\
\hline $2009-2013$ & -0.0237 & 0.0088 & 0.0141 & \\
\hline
\end{tabular}

Notes: Numbers represent inner products between changes in relative wages and change in relative supplies of 64 cells. Each inner product is calculated using changes across column period and row period. Relative wage measure is constructed from the sample of full-time workers in the formal sector while relative supply is calculated from the sample of workers in the formal sector.

Source: Author. 


\section{Technology Change and Skill Demand by Enterprises in Asia}

The change in demand for skilled labor of firms in South Asian and Southeast Asian countries was investigated, including whether the technological change of these firms influences skill demand. Using firm-level data from the World Bank's Enterprise Survey, an analysis was conducted to determine whether demand for skilled worker is related to technological changes.

In developed countries, technological advancement is the main factor of demand for skilled workers (Berman et al. 1994). Studies using firm-level data of developing countries, albeit limited in number, have confirmed that the level of trade and openness to foreign technology is related to higher share of skilled workers (Lee and Wie 2015a, Almeida 2010, Berman et al. 2005). For instance, using firm-level data from East Asian developing countries, Almeida (2010) showed that higher levels of technological innovation and foreign direct investment (FDI) are related to greater skill demand. Whether this relationship also holds using a larger sample of South Asian and Southeast Asian countries was examined.

To examine the effect of technological changes on demand for skilled workers, nine national rounds of World Bank enterprise surveys were analyzed covering the following eight Asian countries: Bangladesh (2002), the PRC (2003), India (2002 and 2006), Malaysia (2002), the Philippines (2003), Sri Lanka (2004), Thailand (2004), and Viet Nam (2005). Although available for these countries, more recent survey rounds were not included in the sample due to lack of technology indicator. Although the sample firms are not the same in the multiple rounds of an individual country, the increasing trend in the share of non-production workers can be observed in all Asian countries in the sample (not shown here). For example, the share of nonproduction workers increased from around 10\% in 2003 to over $50 \%$ in 2009.

\section{Figure 29: Share of Nonproduction Workers}

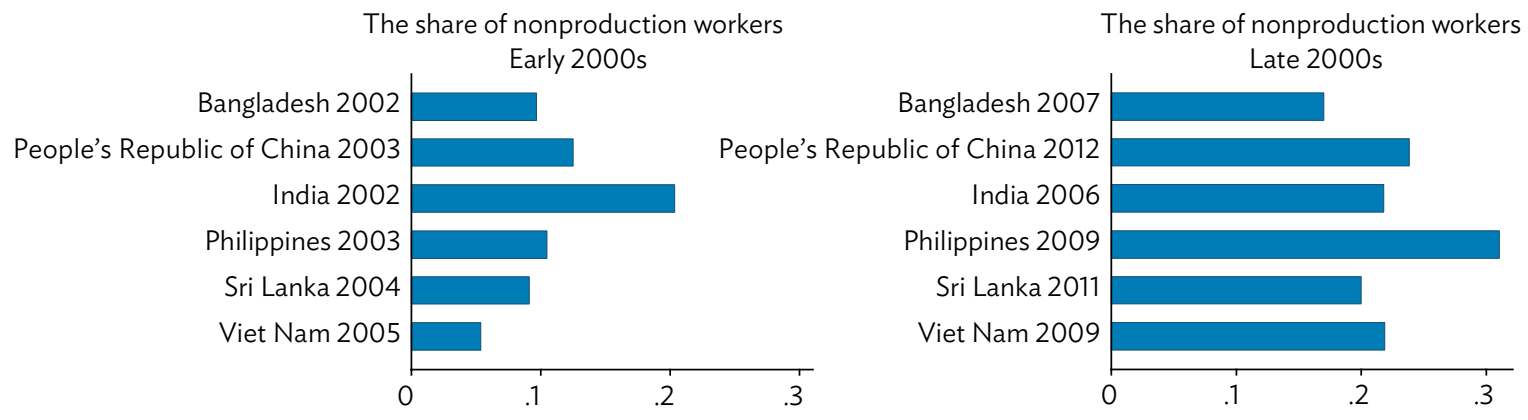

Source: Author. 
The following equation was estimated to find out the association between technology and capital on demand for more skilled workers, while controlling for other firm-, industry-, and country-specific factors. The specification relates changes in nonproduction workers' employment to technological measures. The share equation is derived from a translog cost function, which is commonly used to measure skill-biased technological change (Berman et al. 1994, Machin and Van Reenen 1998):

$$
\begin{aligned}
\text { Share_Skills }_{i j t} & =\beta_{0}+\beta_{1} K_{i j t}+\beta_{2} \text { Sales }_{i j t}+\beta_{3} \text { Wage }_{i j t}+\beta_{4} \text { Technology }_{i j t}+\beta_{5} \text { Industry }_{j} \\
& +\beta_{6} \text { Country }_{t}+\varepsilon_{i j t}
\end{aligned}
$$

where Share_Skills $s_{i j t}$ indicates share of nonproduction workers of each firm $i$ in $j$ industry of $t$ country-year, $\mathrm{K}$ is the logarithm of capital share or the share of the net value of capital in total sales in the past year, Sales is the logarithm of total sales in the past year, Wage represents relative wages in the past year, Technology indicates the extent of technological innovation or adaptation which is represented here by the share of research and development (R\&D) investment to sales in the past year and the use of internet (e-mail use for external communications), and finally Industry and Country are dummy variables to control for industry and country-specific factors that may affect skill demand. Employment pattern of companies by industry is important to understand demand for workers.

With this specification, the conclusion was that there is capital-skill complementarity when $\beta_{1}>0$ (Krusell et al. 2000). The coefficient $\beta_{1}$ would estimate the effect of technology on demand for skilled labor. Exports and foreign ownership were also considered as additional variables that can be related to technological development. Table 26 presents a summary of descriptive statistics for our sample.

The regression results are presented in Table 27. Column (1) reports the estimation of the specification without relative wage variable by taking into consideration the possible endogeneity of wage. Result in column (1) covers all the survey rounds described earlier, including the 2002 and 2006 survey rounds for India. However, because the 2002 round for India does not have separate information on wage bill paid to production workers and

Table 26: Descriptive Statistics: World Bank Enterprise Survey Data

\begin{tabular}{|l|r|r|r|r|r|}
\hline Variable & Obs & Mean & Std. Dev. & Min & Max \\
\hline Share of nonproduction workers (\%) & 7,701 & 13.87 & 15.21 & 0 & 100 \\
\hline Log (capital share) & 7,701 & 0.48 & 0.67 & 0.00 & 11.06 \\
\hline Log (sales) & 7,701 & 10.68 & 3.12 & -1.61 & 23.19 \\
\hline Log (relative wage) & 6,023 & 0.57 & 0.47 & 0.00 & 1.65 \\
\hline Share of R\&D in sales (\%) & 7,701 & 0.97 & 7.23 & 0 & 100 \\
\hline $\begin{array}{l}\text { Internet use dummy (1 if using e-mail for } \\
\text { communication, 0 otherwise) }\end{array}$ & 7,701 & 0.52 & 0.50 & 0 & 1 \\
\hline $\begin{array}{l}\text { Exporter dummy (1 if exporting products, } \\
\text { O otherwise) }\end{array}$ & 7,701 & 0.28 & 0.45 & 0 & 1 \\
\hline $\begin{array}{l}\text { Foreign ownership dummy (1 if majority of } \\
\text { shares are foreign-owned, 0 otherwise) }\end{array}$ & 7,701 & 0.13 & 0.33 & 0 & 1 \\
\hline
\end{tabular}

$0=$ magnitude zero, Max = maximum value, Min = minimum value, Obs = number of observations, R\&D = research and development, Std. Dev. = standard deviation.

Source: Author. 
nonproduction workers, the results in columns (2) and (3), which included the variable on relative wage, did not cover the 2002 round. Aside from R\&D investment and use of internet, the specification in column (3) also included foreign ownership dummy as an additional technology variable. All the specifications included exporter dummy variable.

All these three specifications show that the capital-skill complementarity and technology effect are both positive and statistically significant in the sample. An increase in the ratio of capital to sales translates into a significant increase in the proportion of skilled workers to total workers in the following year. The estimated coefficients on R\&D variable imply that, for every 1 percentage point increase in the share of R\&D investment to total sales, the share of skilled workers increases by $0.05-0.06$ percentage points. It is also interesting to note that firms using internet or e-mail for external communications, which are usually more technologically sophisticated, require more skilled workers (i.e., 0.9-1.3 percentage points more) than otherwise. These confirm the presence of skill-biased technological change in these firms. The strong positive effect of technological change on skill demand is held robust regardless of inclusion of relative wage.

Table 27: Regression Results for Nonproduction Workers' Share in Employment

\begin{tabular}{|l|c|c|c|}
\hline Explanatory Variable & $(1)$ & $(2)$ & $(3)$ \\
\hline Log (capital share) & $0.8009^{* * *}$ & $0.6736^{* *}$ & $0.6665^{* *}$ \\
\hline & {$[0.231]$} & {$[0.227]$} & {$[0.245]$} \\
\hline Log (sales) & $0.4035^{*}$ & 0.2581 & 0.2517 \\
\hline & {$[0.190]$} & {$[0.145]$} & {$[0.158]$} \\
\hline Log (relative wage) & & $-6.5721^{* * *}$ & $-6.5954^{* * *}$ \\
\hline & & {$[0.349]$} & {$[0.400]$} \\
\hline Share of R\&D in sales (\%) & $0.0571^{* *}$ & $0.0497^{* *}$ & $0.0493^{* *}$ \\
\hline & {$[0.019]$} & {$[0.019]$} & {$[0.020]$} \\
\hline Internet use dummy & $0.9329^{*}$ & $1.3086^{* *}$ & $1.3057^{* *}$ \\
\hline & {$[0.433]$} & {$[0.419]$} & {$[0.424]$} \\
\hline Foreign ownership dummy & & & 0.1790 \\
\hline & & & {$[1.053]$} \\
\hline Exporter dummy & $-2.7422^{* * *}$ & $-1.9935^{* *}$ & $-2.0234^{* * *}$ \\
\hline & {$[0.756]$} & {$[0.542]$} & {$[0.426]$} \\
\hline Constant & 2.8727 & $16.3505^{* * *}$ & $16.4265^{* * *}$ \\
\hline & {$[2.022]$} & {$[1.188]$} & {$[1.469]$} \\
\hline & & & 8,023 \\
\hline Survey rounds & 9.761 & 6,023 & 8.164 \\
\hline Observations & 0.157 & 0.164 & 8 \\
\hline R-squared & & & 8 \\
\hline
\end{tabular}

$R \& D=$ research and development.

Note: Robust standard errors in brackets. ${ }^{* *} p<0.01,{ }^{* *} p<0.05,{ }^{*} p<0.1$. Specifications (2) and (3) exclude India (2006).

Source: Author. 
The results in the specification (3) show that the effect of FDI on skill demand is not statistically significant. This may come from the measurement of foreign ownership (as a binary indicator variable in this data set) and the time lag between introduction of FDI and interaction with human capital. Previous literature, including Lee and Wie (2015a), found the positive impact of technological changes induced by foreign investment on demand for skilled labor.

The coefficient of the exporter dummy variable is negative and statistically significant, consistent with existing literature (Almeida 2010, Lee and Wie 2015a). Export-oriented firms in developing countries, which usually specialize in labor-intensive products, are less likely to hire skilled workers and rely mainly on relatively cheap labor for production. 


\section{POLICY RECOMMENDATIONS FOR HUMAN CAPITAL DEVELOPMENT}

\section{Highlights}

- South Asian countries need to focus on improving the quality of education and broadening access to it to address the poor and high disparity in learning outcomes, and stand a better chance to compete in the global economy.

- More efforts are required toward improving the readiness of graduates to satisfy the changing demands of today's job market.

- Mainstreaming education and skills development in national development policies are important to strengthen commitment, and to ensure that education and skills development could support economic development priorities.

This section focuses on some of the key high-level policy directions toward addressing the key education, skills development, and employment challenges in South Asia presented in previous sections.

\section{A. Access and Quality}

Building human capital and a well-skilled labor force for a modern, competitive economy requires good quality, inclusive education. Although South Asia has made a tremendous progress in expanding access to schooling over the past decade, high increases in enrollment rates mask serious deficiencies in inclusiveness of education and learning. Countries in the region are now facing two major challenges. First, there is still a substantial number of children who remain out of school, nearly 21 million children aged 8-14. Second, more attention should be placed on boosting the quality of education at all levels. Due to the focus of education policies led by government on educational expansion, learning outcomes at all levels are still poor compared with other countries. Quality of teachers is still low, especially in rural areas. A large proportion of students completing primary school lack basic numeracy and literacy skills. Additionally, students have a limited access to postprimary education, which is often of poor quality.

To ensure that children receive quality education, UNESCO (2014) recommends several important teaching reforms to policy makers. For instance, technical reforms are for quality improvement such as closing teacher gaps, training teachers to meet the learning needs of all children preservice and in-service, developing classroom assessments to help teachers identify and support weak learners, preparing teacher educators and mentors to support teachers, and providing better data on trained teachers. In addition, a system that rewards 
good performance, acquiring new skills, and greater accountability through a favorable career progression and performance-related pay structure will likely foster better learning outcomes.

South Asia should now look beyond enrollment rates, and shift its focus toward boosting quality, strengthening inclusiveness, and improving relevance of skills at all levels of education. Pursuing policies that can improve the poor quality of education should now be a priority for a more sustainable economic development. In the Republic of Korea, a low-cost, gradual quantitative expansion strategy-from elementary to secondary education, and then to tertiary education, from rural to urban areas - was initially pursued, given the limited resources available following the Korean War (Box 8). After the expansion targets were successfully reached, focus shifted on qualitative improvements, and the same sequential approach was followed. Average student-teacher ratio was reduced significantly, after it ballooned during the expansionary period, and teacher qualifications were systematically upgraded (Lee 2008). ${ }^{30}$ Today, students in the Republic of Korea are among the world's top performers in both mathematics and science, as shown by international achievement test results.

\section{Box 8: Sequential Development of Education in the Republic of Korea}

After the post-war reconstruction of schools, the Government of the Republic of Korea pursued a temporary low-cost approach to quantitative educational expansion toward achieving its post-war goal of universal primary education. At this time, the education budget was severely constrained and the primary school-age population was still growing. Although primary education was made compulsory starting in 1954, parents had to initially buy textbooks and pay supplementary fees to operate the schools. Fees were later abolished, and free textbooks were provided to poor families, starting with rural schools and later extending to urban schools.

A similar approach was followed to universalize secondary education in the 1970s, followed by tertiary education in the 1980s. After the entrance examinations for middle and high schools were abolished in the early 1970s, compulsory education was extended to include lower-secondary education. Tuition and textbook fees were also later removed at the lowersecondary level, starting with the poor families in remote rural and fishing communities. By 1979, admission was universalized at the middle school and at the high school levels years later.

A fixed proportion of domestic tax revenues (around 13\%) was set aside for elementary and secondary education through legislation between 1961 and 1980. This translated into remarkable improvements in education conditions, which deteriorated during the earlier years of enrollment expansion, as the economy grew. The 1974 High School Equalization Policy reinforced this by equalizing school inputs, such as operating expenditures, student intake, class size, and education facilities, in both private and public high schools. Because of this, quality differences across public schools or between private and public institutions were diminished.

Another period of educational quality improvement and expansion of opportunities for higher education followed in 1981-2000. Greater emphasis was given on learner-centered education, program diversification, and autonomy and accountability of school operations. A new monitoring and evaluation mechanism was implemented to assess the results of school education.

Source: Lee, C. J. 2008. Chapter 5: Education in the Republic of Korea: Approaches, Achievements, and Current Challenges. In B. Fredriksen and J. P. Tan, eds. An African Exploration of the East Asian Education Experience. Washington, DC: World Bank.

\footnotetext{
30 Average class size at the upper-secondary level declined from around 60 in 1985 to only 34 in 2005 in the Republic of Korea. Similarly, at the lower-secondary level, it went down to 35 in 2005 from over 60 during the period 1955-1985.
} 
Beyond these technical solutions to poor learning outcomes, larger issues of accountability and governance in the education sector need to be addressed immediately. The strong nexus among teachers, politicians, and government officials in South Asia weakens teacher accountability in many cases and undermines efforts to improve learning outcomes among students (UNESCO 2014). Given the persisting system-wide governance and accountability issues in the region, pursuing any of these reforms would also require governments in South Asia to build coalitions with various stakeholders (i.e., communities, teacher unions, schools, and civil society groups) to obtain their support for reforms.

\section{Invest in upgrading and monitoring educational quality toward achieving better learning outcomes.}

\section{Improve teaching quality.}

Persistent weaknesses in the quality of education lead to substantial learning deficiencies that progress as students move to higher levels of education. As discussed in section III.B, upgrading teacher quality is a key to improving learning outcomes in South Asia. More teachers who are qualified, trained, and committed to broadly support a large, growing population of students, as well as effectively handle weak learners, are required, especially at the primary and secondary levels across the region. Teachers should be well-equipped to engage students in classroom discussions and develop critical thinking, and other core cognitive and noncognitive competencies among them. As learning goes beyond the classroom, schools and teachers should also enable students to engage in alternative learning experiences.

Increasing public investment to address the urgent need in improving overall teaching quality is crucial to upgrade educational quality in South Asia, especially at the primary and secondary levels. Having more teachers with better teacher training, better motivation, and more accountability are very important in improving school quality. Clear and transparent recruitment standards through deployment and transfers are necessary for building a quality teaching force (Dundar et al. 2014).

Ensuring long-term investment to support teachers' continuous professional development is also very important for retaining and expanding a well-trained teaching workforce, which is necessary in sustaining quality improvements, and achieving better learning outcomes in the region. Creating a professional environment that encourages growth and development is also important in recruiting new talented graduates to augment the existing pool of teachers. For instance, in addition to ensuring initial preservice training for all new teachers, the ongoing in-service training for all teachers has demonstrated positive results for improving teaching quality in several developing countries. Recognizing and rewarding exceptional or innovative individual and team performance among teachers could help foster excellence in the teaching profession.

In East Asia, aside from having high private investments in education, to improve the quality of education, high-paid and better-qualified teachers are employed. Moreover, the operations and activities of individual educational institutions in the region are largely under the government's control (Ashton at al. 1999). 
Enforce quality standards and promote better accountability.

Periodic assessment of teachers' capacity and student performance could help promote accountability among teachers toward addressing quality challenge. It would be difficult to address capacity and learning gaps and assess effectiveness of quality improvement interventions unless performance is periodically measured. Strengthening school leadership and management in facilitating internal and external periodic assessments could help promote teacher quality. Schools and teachers should aim at enabling students to achieve local and international standards for learning.

Aside from traditional monitoring and assessment channels, use of information and communication technology (ICT) can also be considered in continually updating knowledge and skills of teachers, as well as assessing them. Nationwide assessment of students based on national curriculum and internationally accepted standards of learning, and providing school feedbacks could also help promote better learning outcomes. Effective quality improvement interventions, as demonstrated by several randomized trials in South Asia, can also be considered for scaling up.

\section{Narrow gender, geographical, and socioeconomic disparities in school} attainment and outcomes.

Countries need to foster equity and inclusiveness investments throughout the education systems (ADB 2010a, 2010b). As in other countries, even in countries in South Asia with high enrollments, children who are unable to go to school tend to be from disadvantaged groupspoor families, rural residents, ethnic and linguistic minorities, people with disabilities, refugees, and migrants. Countries must ensure that all learners will have an education of good quality, and can progress to reach their full learning potential to help reduce income disparities.

Aside from expanding the pool of qualified and well-trained teachers, ensuring that they are equitably deployed in schools across regions and communities, especially those underserved ones, could help narrow gaps. Use of ICT tools to facilitate classroom and distance learning is also a promising mechanism for tackling geographical disparities in the quality of education and skills learning.

Countries should improve their financing strategies to foster equity and inclusiveness in education. Scholarships and other assistantships for students from socially or economically disadvantaged families could also help reduce educational gaps. Countries must improve their capacity in targeting social protection measures toward reaching female students, and students from poor families and other disadvantaged groups. Education scholarships and stipends linked with conditional grants have produced positive impacts, particularly when targeted at girls and poor households.

Engaging the interest of local governments and rural communities to demand better learning outcomes can also help address geographical disparities. Empowering them to leverage their local resources toward better performance from local schools may not only help fill financing gaps and other resources, but also help ensure greater quality and accountability in the local school systems and outcomes.

They can also be tapped in facilitating distance education and skills development that are adaptable to the needs of rural children and families with different social and economic backgrounds. Promoting adult education and alternative learning experiences using ICT 
and other tools can especially help mothers and students in communities where learning outcomes and school participation are particularly low. This could help in promoting school participation among children from disadvantaged communities.

\section{Improve secondary and tertiary education to match the changing skill demand.}

A sufficient proportion of labor force with good quality tertiary and advanced education is crucial in a modern, competitive, and productive economy. At the same time, the changing skills requirements of labor markets and the increasing universalization of basic education in South Asia are increasing pressures to expand and, more importantly, improve secondary and postsecondary education. Secondary and tertiary schools are increasingly demanded to yield graduates with skills that are relevant to the labor markets, and on par with industry standards.

Encouraging greater partnership between educators and employers is a promising way toward narrowing the gap between the skill supply and demand. Such partnership could facilitate the joint development of curriculum standards, internship, workforce exchange, as well as financing (more discussion on this in section VI.C). With the use of ICT, governments could consider supporting a system that provides relevant and up-to-date information to employers, training providers, and workers. Availability of reliable and relevant information could help ease matching of skill demand and supply.

Promoting the integration of internship programs and other practical learning experiences in secondary and tertiary curriculum could also ease the greater production of graduates with employable skills. In Sri Lanka, the government is now piloting a new technology stream to prepare students who are pursuing technical jobs or higher education (Box 9).

\section{Box 9: Linking Education to Jobs in Sri Lanka}

To give students a better chance at entering university or the job market, Sri Lanka is now introducing its secondary students to a subject stream that focuses on advanced technology. The new technology stream focuses on preparing students who are interested in engineering or technical sciences to better opportunities for pursuing technical jobs, self-employment, or higher learning in the country's elite universities.

It focuses on practical learning, skills development, and job-relevant training through handson experience in performing experiments in a laboratory, as well as first-hand experience with mechanical equipment through visits in local technical colleges and vocational schools. Several national universities are now introducing a bachelor of technology degree that will be open to students from the technical stream. Students of the new stream can also pursue nationally recognized vocational qualification certificates, even while completing their secondary studies. These certificates open doors to higher-level vocational certification upon graduation or entry-level jobs.

Implementing the new technology stream is one of the government's strategies to respond to the need to modernize secondary education by (i) deepening curriculums; (ii) improving learning outcomes in core subjects such as science, mathematics, and English, and pass rates at both ordinary and advanced levels; (iii) improving school facilities, especially in rural areas; and (iv) developing a national student assessment framework, which integrates school assessments with external exams.

Source: Asian Development Bank. 2015. Linking Education to Jobs in Sri Lanka. http://www.adb.org/ news/features/linking-education-jobs-sri-lanka. 


\section{B. Skills, Employment, and Labor Markets}

Education and skills development play an important role in supporting human resource development. The effective and efficient utilization of human capital depends on the readiness of students entering the university and the employability of graduates in the dynamic labor markets. Achieving these requires cooperation from both the public and private sectors, while each actively plays its role in skills development. Governments and private institutions in South Asian countries must work hand in hand toward expanding their capacity to provide training to their ever-growing workforce, enhancing the quality of workers and their skills to match demand, and harnessing quality employment for different skills level.

1. Boost the quality of training and skills development systems to meet industry standards and hasten job-skill matching.

Technical and vocational education and training (TVET) is a promising tool toward developing skills to meet the country's changing labor demand. However, to achieve a skill demand matching, upgrading the training and skills development systems in South Asia as well as formulating a viable financing strategy to support these quality improvements is required.

Harness skills development standards and qualifications.

Certification tends to be a government responsibility in South Asia. Because this stretches government capacity as enrollment grows, the quality of either training inputs or output is often neglected. As end users of trainees and their skills, employers could play an important role in enforcing quality standards of training programs. The government's certification can help measure and assess graduates. A law enabling joint certification between employers and the government could not only help raise the quality of TVET graduates in the region, but also encourage training providers to be more accountable with the quality of service they provide.

Innovations such as competency-based training and vocational qualification frameworks can help establish appropriate quality standards in place. The poor educational attainment of incoming trainees limits skill achievements. Most TVET systems fail to monitor or evaluate the quality outcomes of training in terms of competencies achieved. While quality assurance standards are not usually applied to individual public training institutions, accreditation for private training providers is normally difficult.

Reforms in trade testing and examinations can be beneficial to the system so long as they are rooted in occupational analysis. Many systems of vocational training focus rigidly on preparation for terminal examinations or trade tests. Too often the test instruments have become obsolete, and disconnected from labor market requirements. Employers may pay little attention to the formal qualifications in their hiring practices. Still, testing can be used as a powerful means to reform the content of vocational training. The key is to root the tests in the competencies required for the job, as determined by occupational and job analysis. But this also requires adequate training in relevant competencies for the examiners and assessors. That is why the need for direct industry and employer involvement in assessment is emphasized, which should be mandated in South Asian countries by law. 
In many countries in Asia, including those in South Asia, migration to other countries for jobs is accelerating. While this type of migration raises the need to set internationally acceptable training standards, South Asian countries are still not moving toward this direction. Although India and Sri Lanka have their own frameworks for national skills qualification, efforts to revise the frameworks to conform to international standards remain lacking.

In Viet Nam, although progress is slower than expected, a national skill standards is being set to conform to regional and international standards in consultation with the various enterprises in the country (ADB 2013b). The government also plans to develop regionallevel and international-level skills standards. The government intends to adopt and adapt the skills standards used by regional neighbors, such as Malaysia, and those used by countries outside the region, such as Australia, Germany, and the United Kingdom.

Unlike in other countries in East Asia and Southeast Asia, South Asian TVET systems are deficient in practical training. There is also no clear distinction or relationship between lower- and higher-level TVET institutions in South Asia. For instance, the technical secondary and vocational secondary streams in Viet Nam used to be differentiated by the theoretical and practical contents of their respective curriculum. While the technical secondary schools had a curriculum that was about $40 \%$ practical and $60 \%$ theoretical, the ratio was about $70 \%-30 \%$ in vocational secondary schools. The greater theoretical content of the technical secondary school curriculum qualifies its graduates to enroll in colleges and universities. ${ }^{31}$

In contrast, graduates of vocational secondary schools in South Asia are not automatically eligible to enroll in technical colleges. Similarly, graduates of vocational colleges are not readily qualified to enroll in universities. With the recent initiation of the National Skills Qualification Framework, this issue is now being addressed in India. A better distinction between industrial training institutes, which are now managed by the MOL, and secondary vocational institutions, which are managed by the Ministry of Human Resource Development, will hopefully improve distinction of training levels, as well as encourage skills development progression.

\section{Upgrade quality of technical teachers.}

In addition to a lack of facilities, equipment, and updated materials, finding teachers or instructors is another problem that TVET institutions throughout South Asia are facing. The level of skills and knowledge of teachers and work-based instructors is a key determinant of the quality of any country's system of education and training. Inadequate numbers and qualifications of instructors are among the main factors responsible for the low quality of instruction. A significant proportion of teachers in vocational institutes in India lack the requisite teaching skills and the relevant industry experience. Public bureaucracies seldom recognize the need to certify and remunerate instructors based on industrial experience. In addition, due to poor career growth prospects, attrition rate is also high among faculty in vocational institutes.

\footnotetext{
31 Encouragingly, this situation has recently been rectified in Viet Nam. The proportion of theory and practice has been more standardized across two types of institutions, and a vocational college graduate may now enter university.
} 
A lack of quality teachers used to be a problem in Viet Nam when the participation by the industry in TVET activities was minimal. Teachers are mainly recruited from universities that provide degree programs in education or other relevant disciplines. Colleges used to employ workshop instructors, who are often graduates of the college who have some workplace experience, to provide training in practical work within school facilities. However, these instructors do have some technical and instructional skills, but do not have pedagogical training in integrating theory with practice. Consequently, there is poor integration between the knowledge developed through theory classes and the skills developed in college workshops (UNEVOC 2012).

To address this issue, along with other challenges, Viet Nam carried out several TVET reforms toward improving knowledge and skills of technical teachers (ADB 2013b). To develop more technical teachers, Viet Nam instituted a vocational teacher competency certificate course for prospective teachers with noneducation degrees. Delivered through universities and teacher training institutions, the course normally takes 6 months to complete. It requires students to successfully complete several core modules and two selective modules. ${ }^{32}$ The Ministry of Labor, Invalids and Social Affairs recently required teachers to know how to prepare training curricula from skills standards set by industry and the government. Teachers should also be able to assess the practical and technical competence of students after the training.

Similarly, the TVET system of the People's Republic of China (PRC) has also ensured regular training of technical teachers. Vocational teachers in the PRC are required to have a degree in the discipline or vocation they will teach and a certificate in pedagogy. In addition, to facilitate career progression and promotion, each instructor is required to spend a month working in the industry each year, or for 2 months every 2 years. Practical training at the enterprises equips them with knowledge of evolving industry needs.

Improve relevance and responsiveness of skills training programs to changing market demand.

Moving South Asian TVET systems from a supply-oriented to a more market demandoriented system, training system is essential to ensure relevance of education and skills to the changing industry demand. A review of technical and vocational education projects funded by ADB across countries in Asia and the Pacific has concluded that strengthening a linkage with industry is the single most important factor in training success (ADB 2004).

To build a more demand-oriented TVET system, governments in South Asia should consider some of the following steps: (i) appointing employers in governance structures, which is beginning to happen at least in industrial training institutes in India, though not very effectively so far (Mehrotra 2014); (ii) institutionalizing regular tracer or tracking studies to measure the effectiveness of training programs and continually change program offerings accordingly, which again happens rarely; (iii) paying incentives to providers for meeting market-based performance standards of quantity and quality (e.g., per trainee on schedule, per graduate meeting competency standards, per graduates employed);

32 The core module includes vocational educational psychology, pedagogical skills, management of teaching programs, teaching skills, and subject-specific teaching methods. The elective modules may include science methods in vocational education, curriculum development techniques, technology teaching methods, and use of information technology in teaching. 
(iv) making managers and institutions accountable for results to boards of governors dominated by employers; ( $v$ ) earning all or some of the budget through the market; (vi) making institutions autonomous with proper safeguards and accounting controls; (vii) enforcing competitive bidding for private companies to manage public training centers; and (viii) renting premises and equipment, while hiring instructors through short-term contracts, for greater flexibility.

The experience of the Republic of Korea is generally instructive for South Asia, particularly in India, which has a large industry sector to consider. The Republic of Korea's training system is designed to meet the training needs of both workers and employers (Oh 2013). Workers, who are unemployed, either with or without previous work experience, and are seeking for a job, are entitled to have individual training accounts which cover the cost of training. This helps unemployed workers to obtain skills that they can use for their future job. The Republic of Korea's training cost reimbursement system, which, as part of its employment insurance system, is designed to support companies in meeting their skills demand. Companies contribute employment insurance premiums and are entitled to posttraining reimbursements that are proportional to their contributions. ${ }^{33}$ The training fund, which is provided through a reimbursement mechanism, provides employers an incentive to train their own employees, which they would not be able to access otherwise. Because small and medium-sized enterprises (SMEs) usually lack time and resources needed to provide training, some SMEs form a training consortium to implement training more efficiently (Oh 2013).

The centralized TVET systems in South Asia, which tend to be government- and supplydriven, suffer from lengthy decision-making processes, remoteness from clients, and rigidity to change. Giving training institutions independence in operation-procurement and human resource management, program development and marketing, and income management-could help improve the responsiveness of training services to demand. It allows training institutions to generate and mobilize their own resources, as well as develop their market, and forge closer relationships to the labor market. Although full autonomy may require more planning and monitoring, partial autonomy may be realistic and generate impact (ADB 2009).

Flexibility in terms of introducing new courses and designing its curriculum is urgently needed in South Asia. For instance, in the PRC, local industry participation in TVET is encouraged, as provided for in the 1996 Vocational Education Law. The curriculum of a senior secondary vocational school is designed such that one-third consists of general academic skills defined nationally by the Ministry of Education, another one-third is again nationally defined content associated with the particular occupation, and the remaining one-third is defined again with respect to the occupational field, but is determined locally at the school level with the help of local enterprises. This flexibility allows for the curriculum for each trade to have a local content. Such flexibility in curriculum design is not yet allowed in South Asia. For instance, in India, flexibility is needed in both industrial training institutes and vocational schools.

33 A similar system is in place in Malaysia and Brazil. Variants of the system are also found in 63 countries worldwide. See Mehrotra (2013) for a detailed discussion of such funds. 
South Asia has a large rural population that aspires to migrate to cities and to better jobs outside of agriculture. Many Southeast Asian countries had the same problem during the earlier stage of their economic development. Both the PRC and Viet Nam are now facing the same problem. For long purpose-built training schools, the PRC has already the workforce to help adults who only have informally acquired skills on the job. Recognizing the need to adopt a demand-driven approach, Viet Nam's Rural Training Programme is designed to improve the quality of rural labor toward supporting industrialization and modernization of the agriculture sector (UNEVOC 2012). It intends to link training to socioeconomic development strategies and road maps nationally, regionally, sectorally, and for each locality. It seeks to provide vocational training for an average of about 1 million rural workers per year, which improves the quality and then increases incomes, in turn contributing to restructuring the efficiency of vocational training to generate employment (ADB 2012).

\section{Facilitate a favorable environment for skills development and training and improve public-private partnership.}

Shifting the role of skills training to the private sector, while strengthening the government's role and capacity to regulate the private sector, could better lead to sustained, adequate investments in TVET. Private training providers in South Asia remain unregulated. Lessons from the experience of other Asian governments can be useful in this regard. For instance, the regulatory environment for private training providers, which tend to concentrate on fields such as ICT, business subjects, and languages, is relatively favorable (UNEVOC 2013). Private providers can set their own fee levels, as long as they inform the responsible state authority, and go through the same registration screening as public institutions. Each provider must have a board of directors that selects and endorses a manager of the institution for government recognition. Private providers follow the same curriculum framework as public institutions. Private providers meet the bulk of the growing training needs of Viet Nam. According to the draft TVET Strategy 2020, private training provision is expected to increase from $20 \%$ of enrollees in technical secondary schools to $40 \%$ by 2020 (UNEVOC 2013).

Governments also need to recognize that there are limits to their role in skills development. Beyond being a provider of TVET in the economy, the government should play an active role in providing skills training where private solutions are not found. For example, certain geographical areas or highly strategic skills are too costly for private providers to cover. Nonetheless, governments should refrain from entering markets that are adequately served by private training providers to avoid crowding them out. To the extent that nonpublic providers are available and more efficient, the government can maximize the production of skills by financing its training through them, but even this financing of skills training should be largely confined for economically and socially disadvantaged groups, and for key occupations not covered by the private sector. Case studies have shown that excessive government control of training programs in Asian countries were sometimes not only ineffective, but discouraged private firm training (Lee 2001, Ashton et al. 1999).

Governments should also play an active role in providing the public with information about labor market requirements, as well as the training system (i.e., options available to students and parents) and the performance of the public system. The government should also share information with citizens about the scope, quality, outcomes, and cost of private provision. For instance, in India, the number of private industrial training institutes grew from 2,000 in 
2007 to 10,000 in 2014 , but enhancement in the ability of the MOL to monitor quality and outcomes is necessary.

Another role of government in creating demand for TVET would be to disseminate information (if such data were first collected), whether vocational education or training is more likely (than general academic education) to get youth a job. An analysis of private returns to general education and vocational training based on data from the 2008 Viet Nam Household Living Standards Survey has shown that workers with vocational training (including short-term training) are more likely to be employed than workers with a general education (ranging from no formal education to upper secondary) (ADB 2013b). It is only at the tertiary level that general education has better employment and wage outcomes than vocational college. Furthermore, workers with technical or vocational training at either the secondary or tertiary level earn $32 \%$ more than the average wage earner. Such research is needed in South Asia to show that youth with better skills are more likely to get a job.

Apprenticeship, which usually provides skills to young people by a master craftsperson, is the dominant form of skills acquisition in the informal economy, particularly in South Asia. Assisting the poor to finance their training could help expand access to apprenticeship. Upgrading the skills of master craftspersons, as well as linking apprenticeship with specialized training providers through facilitators and vouchers, could also help improve skills development and facilitate training support to informal sector associations. In addition, introducing supplementary training for apprentices could also contribute to skills development in the informal sector. Apprentices could also benefit from theoretical training to grasp the basics of the trade such as measuring, calculating, reading of drawings; and expanded technical training, e.g., on unavailable equipment in their workshops.

Encourage public-private partnership to promote the matching of skills system curriculum with the current and evolving demands of employers. In-firm training, which remains very low in South Asia, could be stimulated, especially in middle-income South Asian countries. Although public support for in-firm training may be needed in a few clearly defined areas, use of direct public subsidies should be avoided since many enterprises provide their own training without government support. To encourage in-firm training, various measures can instead be adopted to provide enterprises with incentives to expand their own in-firm training programs. These may include training grants or loans to enterprises to help them cover or recover part of the cost of training. Another form of incentive for the expansion of in-firm training is the provision of a wage subsidy by the state during the period of training.

Most of the in-firm training programs conducted in South Asia are in large firms and not in SMEs which are dominant. Such SMEs could be encouraged by governments to join hands, and jointly fund training within a cluster where such SMEs are producing similar products (Mehrotra et al. 2014b). The government should advocate training as a means to increase productivity and profits within such enterprises, but also facilitate such training by offering the premises of government TVET institutions. This could raise the basic skill levels of entrants to the labor market, stimulate training for low-educated workers and workers in small enterprises who have little access to training, and build the capacity of trade and sector associations to provide training services to their members. 
Local governments in the PRC try to attract the support of local enterprises in TVET. Because of fear of punishment (taxation or negative publicity or taint on reputation) at the hands of local governments (empowered by the provisions of the 1996 Vocational Education Law), local enterprises participate in practical training. To help local enterprises, local governments provide incentives such as allotment of land at subsidized prices, or preferential treatment in award of government projects. Such measures encourage industry to actively participate in vocational education and can be adopted in the case of South Asian firms as well.

\section{Harness training and quality employment opportunities for all.}

There is also a pressing need to strengthen skills training for the workforce in the informal sector, which continues to absorb the vast majority of new entrants in the labor market. Although training is not a sufficient condition to raise productivity, skills are essential in helping to raise productivity and income of workers, especially in the informal sector. Most skills training at present are oriented toward wage employment, and are generally irrelevant for the demands in the informal sector. Different from training for wage-workers, training must equip workers in the informal sector with business skills such as market analysis, pricing, and sales.

Foster training and gender-sensitive work environments to encourage greater female labor participation.

Promote TVET programs that are gender-sensitive to encourage and support greater female labor force participation in South Asia. Girls' school enrollment has grown not only at primary level and is especially increasing fast at secondary level in South Asia, but its female labor force participation rates remain the lowest in the world. Unemployed female workers in Asia can enter modern services, and even manufacturing activities in small towns and peri-urban areas, if TVET access is improved (Mehrotra and Sinha 2015). TVET access is generally very narrow in South Asia because of the lack of available TVET courses, especially for girls who prefer to pursue wage and self-employment activities in the services sector. As nonagricultural jobs grow in this region and poverty rates decline, there will be greater demand for women for nonagricultural employment.

\section{Use ICT to expand capacity for providing quality training and education, and make it inclusive.}

Although the evidence concerning the impact of improving learning outcomes is limited and mixed, the opportunities for supporting the delivery of better education and skills development arising from developments in ICT are very promising. There are clearly some benefits for using more affordable and user-friendly ICT solutions in education (Box 10). Nonetheless, a certain degree of caution is needed, especially when scaling up investments toward ICT as a tool for promoting better learning and making it inclusive. Governments in South Asia must initially improve their capacity to carefully formulate and adequately implement ICT strategies that are affordable and effective in reaching underserved, remote areas. Plans incorporating ICT for educational improvement must be based on the country's human development priorities, as well as infrastructure investment priorities. 


\section{Box 10: Benefits of Investing in Information and Communication Technology for Education}

Information and communication technology (ICT) investments for basic and secondary education contribute to

- better information literacy as an important foundation for subsequent learning,

- encouraging open communication between and among students and teachers,

- enhancing learning through ICT-enhanced and interactive student-centered learning experiences, and

- improving teamwork skills that are increasingly required in the labor market.

ICT investments for teacher training and higher education support the following:

- better access to and use of information and resources for enhanced teaching and learning in the classroom,

- improving the relevance of classroom learning and skills development to industry demand;

- distance learning and training programs for students in remote areas,

- developing an "ICT-capable" labor force able to attract foreign direct investment, and

- research and development activities and university-private sector links that are important drivers of innovation and growth.

Sources: ADB. 2009. Good Practice in Information and Communication Technology in Education. Manila; and ADB. 2010. Education by 2020.

\section{National Policies and Regional Cooperation}

As mentioned earlier, building adequate human capital and a well-skilled labor force is crucial in supporting a modern, competitive economy. To ensure adequate national investments, as well as support from other sectors, human development policies and strategies should be coherent with the overall development strategy of the country, as well as the strategies across sectors. Addressing other noneducation challenges, such as the lack of infrastructure and poor governance, is also crucial in reaping the full benefits from human capital development. Regional coordination and cooperation also offer opportunities for achieving better development outcomes in a more effective and efficient manner.

\section{Design human capital development strategies that are coherent} with the national development policy.

Human capital development is important for unlocking the country's development potential in the near term. Coordinating the development of education and skills and training systems with other departments that are responsible for trade and industry development is important in order to ensure that they are coherent with the government's economic and labor policy directions. Human resource development policies should be responsive to various human resource challenges such as the changing industry demand and structural transformation, having high youth unemployment rates, growing youth population, and expanding informal sector. 
Governments have a central role in connecting skills development policies to their national economic development plans to avoid supply and demand mismatches and promote economic transformation. Governments in successful economies in Asia, such as the PRC, the Republic of Korea, and Malaysia, played an active and central role in promoting industrial growth, skills development, and job creation, as well as supporting exportoriented firms. Public policies promoting general academic education, school-based and nonschool vocational programs, and in-firm trainings reinforced each other in creating the necessary human resources and skills to complement rapid industrial development.

In the Republic of Korea, for example, its government-led education and vocational training policy was one of the central factors for its fast economic growth. When the Government of the Republic of Korea designed and implemented an economic development plan in the era of industrialization, its vocational training system was focused on ensuring a smooth supply of skilled workers necessary to execute the plan.

By defining the broad industrial structure and development track that the country would support, an industrial policy could be an important guide for education and skills development priorities. Such policy is lacking in most South Asian countries. In India, the industrial policy of the early 1980s favored import-substituting industrialization heavily, and did not encourage external market opportunities. As a result, industrial development, as well as skills development, was very narrow and limited.

A law to guide the TVET system and to define the responsibility of different stakeholders could encourage greater industry participations in various aspects of TVET, such as curriculum design, teacher training, and certification. However, unlike in many countries worldwide, including the PRC, Germany, the Republic of Korea, as well as Viet Nam and the Philippines, such law is lacking in South Asia. A TVET law, if carefully designed and wellimplemented, could help guide and raise TVET provision in the region. Ideally, it should define the goal of TVET in the country, and the specific responsibilities of the government, at the local and national levels, as well as the skill providers and the business sector. It should also determine the regular updating of certification standards, teacher training, as well as the TVET curriculum in response to the changing demand of the local industry needs.

In the PRC, the 1996 Vocational Education Law, which spells out the roles and responsibilities of the various stakeholders, ${ }^{34}$ was a landmark for its TVET system. It provides for integrating education and training with the industrial process through the participation of local enterprises. In addition, it provides for adult training for those in the workforce, as well as vocational training in rural areas. In other countries, the TVET law also enables the active involvement of the business sector in the assessment and certification of competencies in other countries (e.g. the chambers of industry in Germany). Reforms in the Association of Southeast Asian Nations are moving in the direction toward establishing a regional qualifications framework.

34 The stakeholders include the Ministry of Education and Ministry of Human Resources and Social Security, subnational departments, education and training institutes, and enterprises. 
Since human capital development is a multidimensional issue, conscious efforts toward promoting noneducation policies that support greater human development are also important. For instance, addressing deficiencies in early childhood nutrition is required to tackle learning deficiencies in the region. Similarly, creating a favorable business environment, especially in the formal sector, is crucial to effectively encourage better utilization of available human resources and reduce wage inequalities. Better infrastructure is also necessary to attract more investments and trade in the region.

\section{Pursue sustainable mechanisms for financing quality improvements in education and skills development.}

Sustained and adequate investments in education are required to support quality improvements in education and skills development, and to make education inclusive. Too often, public resources are limited and, unless human development priorities are mainstreamed with national development strategies, securing adequate resources for quality improvements may be difficult. Given the young, growing population in South Asia, greater resources are needed to support improvements across different levels.

Countries should pursue financing strategies to adequately support quality improvements in education across different levels. Because learning deficiencies accumulate as students' progress to higher levels, the sequential or progressive process of reform, which was adopted in the Republic of Korea, may be adapted to South Asian countries. Countries should find proven ways to improve learning within the local context and allow more students to access it. They should pursue innovative and affordable solutions to improving teaching quality, especially in remote areas. Practical ways to periodically monitor and assess teachers and learning improvements will have to be pursued.

Too often, given the limited public sector funds in developing countries, using public funds to finance tertiary education may derail adequate financing to upgrade the quality of basic and secondary education. It is important for the public sector to effectively leverage its resources toward promoting greater private financing, and implementing cost-sharing mechanisms to expand greater access to quality higher education. In many cases, greater autonomy to public higher education institutions encourages greater accountability in the use of public funds and responsibility for raising funds. Governments should also consider providing higher education institutions with more information on potential sources of funds, as well as building their capacity for raising additional resources. Financing strategies that promote equity and inclusion, especially at the higher levels of education, are crucial especially in South Asia. Proven ways to provide quality higher education and better skills and training programs at competitive cost would have to be identified.

Sustainable mechanisms for financing TVET are essential for improving effectiveness and efficiency of training provision. In South Asia, however, financial resources are usually allocated to public training institutions on ad hoc historical bases regardless of performance. This reinforces inefficiency. Countries should consider adopting competitive financing, which has proven effective in creating training markets and reducing unit costs. Training vouchers have been successful in stimulating supply responses in some cases, such as in Chile and Cambodia. Use of normative financing could focus efforts on outputs and results. 
Training levies could be collected from firms to create a training fund, as have been practiced for many decades by over 60 countries worldwide, such as Malaysia, Singapore, and others in Latin America, Europe, and South Africa. Brazil, which has been operating several sector funds based on levies for around 6 decades, exemplifies a successful case. Because these schemes are more effective in countries with a large formal sector (i.e., large tax base), training levies tend to apply almost exclusively in middle- and upper-income countries, where these two essential conditions exist, rather than in low-income countries (Dar et al. 2003, Ziderman 2003).

Among countries in South Asia, India should be able to adopt a training levy and establish a training fund. The levy can be imposed on large and medium-sized firms with 100 workers or more, whether or not workers are permanent employees, or contract workers performing essentially the same tasks as regular, permanent workers. The draft National Skills Policy of India (2015) proposes this levy as a payroll tax (Mehrotra and Ghosh 2012). It was also included in the 12th Five Year Plan (see chapter on Skill Development, volume 3).

Sector- or industry-specific training funds, which have been proven very effective in Brazil, are an alternative to national (centralized) funding models (Castro 2012). A national system of sector-specific funds is flexible and yet could focus more directly on sector training needs. Because it is less bureaucratic and has a greater industry orientation, employers usually prefer this system. However, it does not facilitate redistribution of funds across sectors or financing nonsector-related skill priorities or the development of a common set of core skills that are relevant across industries. Earmarked payroll levies can be viewed as benefit taxation, i.e., those that benefit (employers and workers) pay for the training.

Although, levies could provide a steady and protected source of funding for training, it is unavoidable for governments under fiscal pressure to divert levy proceeds into general government revenues toward more urgent financing priorities. The Brazilian success with such funds shows that, when managed mainly by the private sector, funds achieve their objectives. Government management of such funds should be avoided also because large companies would then be reluctant to even contribute toward such a levy.

The modus operandi varies according to type of scheme: cost reimbursement, levy-grant, or levy exemption (train or pay). The Skills Development Fund in Singapore is a levygrant system. The Human Resource Development Fund in Malaysia uses both the costreimbursement system and levy exemption. Beneficiaries tend to be larger enterprises and, within enterprises, those at higher occupational levels. Small firms tend not to benefit proportionately. Enterprise incentive funds are the most common form of levy scheme worldwide. Rigorous evaluation is generally lacking, but, in some cases, levy schemes have led to an increase in the volume of training within enterprises. Levy-grant systems, in particular, can allocate resources according to national priorities. However, enterprise incentive schemes require administrative capacity to operate and can discourage enterprise participation because of red tape.

Integrating vocational education into the secondary schools curriculum in South Asia could encourage more students from poor families to stay in school. In South Asia, like 
in the PRC many decades ago, very few students opt for the vocational stream, which is often perceived as a dead-end in terms of educational advancement vertically. As noted earlier, the poorest students drop out of school and join the labor market in South Asia directly, without any formal training or preparedness for the world of work. Students and their families face direct (i.e., tuition fee) and indirect costs (e.g., transportation and food allowance, opportunity cost) when participating in school or training programs (Mehrotra and Ghosh 2014). Indirect costs, especially the forgone income when in school or opportunity, are usually substantial and cause school dropouts. These costs usually determine the family's decision to continue in school, and whether in a vocational program or not. Offsetting these two costs may encourage the expansion of TVET. More demand can be generated among the poor by providing stipends to be drawn from a national training fund based on the training levy on large enterprises.

In the PRC, to encourage more students to pursue vocational education, a special stipend is given to those in secondary high schools, and those from rural areas. The stipend covers board and lodging expenses. This is on top of the subsidy for all vocational students (since 2009), which covers the full cost of tuition. These have shown very positive outcomes. Having an employment rate of around 95\% among senior secondary vocational school graduates demonstrates the high level of external efficiency of the PRC's TVET system. South Asian countries need to find a way to do the same.

\section{Enhance regional cooperation for human development.}

While some challenges need to be closely examined at the national and local contexts, many education and skills development challenges, which are common across South Asia as well as in other Asian countries, could be tackled through greater regional cooperation on these areas. Students, teachers, and workers in South Asia could also benefit from stronger regional coordination and cooperation in teacher training, student assessment, curriculum development, regulation, as well as the use of ICT solutions in education. Countries in South Asia can learn from the experience of the countries in East Asia and Southeast Asia on skills upgrading, industrial development, and strategic financing.

International and regional development partners should forge closer cooperation among South Asian, Southeast Asian, and East Asian economies in human resource development. They could leverage their resources toward promoting knowledge-sharing, expert and student exchanges, research collaborations, and technology-sharing to improve school productivity and promote effective learning across countries in Asia.

Promoting greater mobility of students and labor across countries and improving flexibility of labor markets offer great promise in reducing wage disparities. Estimates by the McKinsey Global Institute (2012a) based on current global patterns of demographic trends, educational attainment, and demand growth suggest that there will be global shortages of around 38 million-40 million highly skilled workers by 2020 , and an oversupply of around 89 million-94 million low-skilled workers (10\% of the supply of such workers). A substantial proportion of these excess low-skilled workers should be trained to become medium-and high-skilled workers. In addition, increase in labor mobility can help improve the allocation of skilled workers across economies. 
Monitoring and facilitating short-term labor migration across countries in Asia could help hasten skill formation and regional transfer of knowledge, employment of human resources, and greater labor productivity. Students and workers in South Asia could also benefit from better coordination in quality assurance systems and qualifications, which can promote mobility of students, teachers, and laborers, as well as encourage investments in South Asia. 


\section{REFERENCES}

Abramovitz, M. 1986. Catching-up, Forging Ahead, and Falling Behind. Journal of Economic History. 46(2):385-406.

Adair, L. S., C. H. D. Fall, C. Osmond, A. D. Stein, R. Martorell, M. Ramirez-Zea, H. S. Sachdev, D. L. Dahly, I. Bas, and S. A. Norris. 2013. Associations of Linear Growth and Relative Weight Gain During Early Life with Adult Health and Human Capital in Countries of Low and Middle Income: Findings from Five Birth Cohort Studies. The Lancet. 382(9891): 535-534.

Adams, R. H., Jr., and A. Cuecuecha. 2010. The Economic Impact of International Remittances on Poverty and Household Consumption and Investment in Indonesia. World Bank Policy Research Working Paper. No. 5433.

Agrawal, T. 2012. Returns to Education in India: Some Recent Evidence. Journal of Quantitative Economics. 10(2):131-51.

Ajwad, M. I., and P. Kurukulasuriya. 2002. Ethnic and Gender Wage Disparities in Sri Lanka. World Bank Policy Research Division Working Paper. No. 2859.

Alailama, P., and N. Sanderatne. 1997. Social Policies in a Slowly Growing Economy: Sri Lanka. In S. Mehrotra and R. Jolly, eds. Development with a Human Face. Oxford: Clarendon Press.

Alderman, H., ed. 2011. No Small Matter: The Impact of Poverty, Shocks, and Human Capital Investments in Early Childhood Development. Washington, DC: World Bank Publications.

Alderman, H., J. Hoddinott, and B. Kinsey. 2006. Long-term Consequences of Early Childhood Malnutrition. Oxford Economic Papers. 58(3):450-474.

Almeida, R. 2009. Openness and Technological Innovation in East Asia: Have They Increased the Demand for Skills? IZA discussion paper. http://www.econstor.eu/ handle/10419/36093.

Almeida, R.K. 2010. Openness and Technological Innovation in East Asia: Have They Increased the Demand for Skills? Policy Research Working Paper. 5272. World Bank.

Altbach, P. G. 2009. One-third of the Globe: The Future of Higher Education in China and India. Prospect. 39(1):11-31.

Asadulla, M.N. 2006. Returns to Education in Bangladesh. Education Economics. 14(4): 453-368.

Asadullah, M., N. Chaudhury, D. Prajuli, L. R. Sarr, Y. Savchenko, and S. R. Al-Zayed. 2009. Secondary Education Quality and Access Enhancement Project (SEQAEP) Baseline 
Report. Human Development Department, South Asia Region. Washington, DC: World Bank.

Ashton, D., F. Green, D. James, and J. Sung. 1999. Education and Training for Development in East Asia: The Political Economy of Skill Formation in East Asian Newly Industrialized Economies. New York: Routledge.

Asian Development Bank (ADB). 2004. Improving Technical Education and Vocational Training: Strategies for Asia. Manila.

-2008. Report and Recommendation of the President to the Board of Directors: Proposed $\{$ Modality(ies) to \{Long Name of Country\} for the Vocational Education Strengthening Project. Manila.

- 2009a. Financing Technical and Vocational Education and Training in the People's Republic of China. Manila. http://www.adb.org/publications/financing-technicaland-vocational-education-and-training-peoples-republic-china.

- 2009b. Good Practices in TVET. Manila.

-2010a. Education by 2020: A Sector Operations Plan. Manila.

_. 2010b. Strengthening Inclusive Education. Manila.

_. 2011a. Asian Development Outlook Update 2011: Preparing for Demographic Transition. Manila.

- 2011b. Labor Force in Shanxi's Economic Transformation. Report for Shanxi Technical and Vocational Education and Training Development Project (RRP PRC 47029), Unpublished.

_. 2012a. Asian Development Outlook 2012: Confronting Rising Inequality in Asia. Manila.

_. 2012b. Regional Cooperation and Cross-Border Collaboration in Higher Education in Asia: Ensuring that Everyone Wins. Manila. http://www.adb.org/publications/ regional-cooperation-and-cross-border-collaboration-higher-education-asia.

_. 2012c. TVET in Viet Nam - An Assessment. Manila.

_. 2012d. Improving Transitions. From School to University to Workplace. Manila.

_. 2013a. Youth Employment and Skills Development in Asia and the Pacific: By the Numbers. http://www.adb.org/features/youth-employment-and-skillsdevelopment-asia-and-pacific-numbers.

_. 2013b. Viet Nam Labour and Employment: Skills Training for Jobs. Manila.

- 2014. Innovative Strategies in Technical and Vocational Education and Training for Accelerated Human Resource Development in South Asia. Manila. http://www.adb.org/ publications/innovative-strategies-tech-voc-education-training-human-resourcedevelopment-south-asia.

- 2015. Human Capital Development in the People's Republic of China and India: Achievements, Prospects, and Policy Challenges. (city).

Ashton, D., F. Green, D. James, and J. Sung. 2005. Education and Training for Development in East Asia: The Political Economy of Skill Formation in Newly Industrialised Economies. Routledge.

Australian Education International. 2006. The International Education Market in China. http://aei.dest.gov.au/AEl/PublicationsAndResearch. 
Autor, D. H. and L. F. Katz, 1999. Changes in the Wage Structure and Earnings Inequality. Handbook of Labor Economics. 3(A): 1463-1555.

Autor, D. H., L. F. Katz, and M. S. Kearney. 2008. Trends in US Wage Inequality: Revising the Revisionists. The Review of Economics and Statistics. 90(2):300-323.

Baldacci, E. M., T. Guin-Sui, and L. de Mello. 2003. More on the Effectiveness of Public Spending on Health Care and Education: A Covariance Structure Model. Journal of International Development. 15(6):709-725.

Banerjee, A. V., R. Banerji, E. Duflo, R. Glennerster, and S. Khemani. 2010. Pitfalls of Participatory Programs: Evidence from a Randomized Evaluation in Education in India. American Economic Journal: Economic Policy. 2(1):1-30.

Banerjee, A. V., S. Cole, E. Duflo, and L. Linden. 2007. Remedying Education: Evidence from Two Randomized Experiments in India. The Quarterly Journal of Economics. 122(3):1235-64.

Barro R. 1991. Economic Growth in a Cross Section of Countries. The Quarterly Journal of Economics. 106(2):407-43.

—. 1999. Notes on Growth Accounting. Journal of Economic Growth. 4(2):119-37.

Barro, R., and J.-W. Lee. 1994. Sources of Economic Growth. Carnegie-Rochester Conference Series on Public Policy. 40:1-46.

- 2013. A New Data Set of Educational Attainment in the World, 1950-2010. Journal of Development Economics. 104:184-98.

- 2015. Education Matters: Global Schooling Gains from the 19th to the 21st Century. New York: Oxford University Press.

Barro, R. J., and X. Sala-i-Martin. 1992. Convergence. Journal of Political Economy. 100(2): 223-51.

- 2004. Economic Growth. 2nd ed. Boston: MIT Press.

Becker, G. S. 1964. Human Capital: A Theoretical and Empirical Analysis, with Special Reference to Education. New York: Columbia University Press.

Becker, G. S., K. M. Murphy, and R. Tamura. 1990. Human Capital, Fertility and Economic Growth. The Journal of Political Economy. 98(2):S12-S37.

Benhabib, J., and M. M. Spiegel. 1994. The Roles of Human Capital in Economic Development: Evidence from Aggregate Cross-Country Data. Journal of Monetary Economics. 34(2):143-73.

Berman, E., J. Bound, and Z. Griliches. 1994. Changes in the Demand for Skilled Labor within US Manufacturing: Evidence from the Annual Survey of Manufacturers. The Quarterly Journal of Economics. 109(2):367-97.

Berman, E., J. Bound, and S. Machin. 1998. Implications of Skill-Biased Technological Change: International Evidence. The Quarterly Journal of Economics. 113(4):1245-79.

Berman, E., R. Somanathan, and H. Tan. 2005. Is Skill-biased Technological Change here Yet? Evidence from Indian Manufacturing in the 1990s. Annals d'Economie et de Statistique. 79/80:299-321.

Bhagwati, J., and A. Panagariya. 2013. Why Growth Matters: How Economic Growth in India Reduced Poverty and the Lessons for Other Developing Countries. New York: Public Affairs. 
Bhalla, S. S., and R. Kaur. 2011. Labour Force Participation of Women in India: Some Facts, Some Queries. Working Paper. No. 40. Asia Research Centre, London School of Economics and Political Science. http://eprints.Ise.ac.uk/38367.

Becker, G. S., and H. G. Lewis. 1973. On the Interaction between Quantity and Quality of Children. The Journal of Political Economy. 81(2):S279-S288.

Behrman, J. R., and N. Birdsall. 1983. The Quality of Schooling: Quantity Alone Is Misleading. American Economic Review. 73 (December): 928-46.

Blom, A., and H. Saeki. 2011. Employability and Skill Set of Newly Graduated Engineers in India. Policy Research Working Paper. No. 5640. Washington, DC: World Bank.

Borensztein, E., J. De Gregorio, and J.-W. Lee. 1998. How Does Foreign Direct Investment Affect Economic Growth? Journal of International Economics. 45(1):115-135.

Bosworth, B., and S. M. Collins. 2003. The Empirics of Growth: An Update. Brookings Papers on Economic Activity. 2003(2):113-206.

Bosworth, B., and S. M. Collins. 2008. Accounting for Growth: Comparing China and India. The Journal of Economic Perspectives. 22(1):45-66.

Bosworth, R. 2014. Class Size, Class Composition, and the Distribution of Student Achievement. Education Economics. 22(2): 141-165.

Bound, J., and G. Johnson. 1992. Changes in the Structure of Wages in the 1980s: An Evaluation of Alternative Explanations. American Economic Review. 82(3): 371-392.

Brixi, H., Y. Mu, B. Targa, and D. Hipgrove. 2011. Equity and Public Governance in Health System Reform: Challenges and Opportunities for China. Policy Research Working Paper. No. 5530. Washington, DC: World Bank.

Cai, F. 2014. Changing Trends and Future Challenges Facing China's Employment Situation. Perspectives from Around the World 022 April. Research Institute of Economy, Trade and Industry, IAA. http://www.rieti.go.jp/en/special/p_a_w/022.html.

Cai, F., Y. Du, and M. Wang. 2011. Labor Market Institutions and Social Protection Mechanism. Background paper for China 2030. Institute of Population and Labor Economics, China Academy of Social Sciences. Beijing.

Cai, F., D. Yang, and W. Meiyan. 2010. Employment and Inequality Outcomes in China. Paper presented at the OECD and European Union Join High-Level Conference. OECD Conference Centre. 19 May.

- 2010. Growth and Structural Changes in Employment in Transition China. Journal of Comparative Economics. 38(1):71-81. http://www.sciencedirect.com/science/article/ pii/ S0147596709000845.

Cain, J. S., R. Hasan, R. Magsombol, and A. Tandon. 2010. Accounting for Inequality in India: Evidence from Household Expenditures. World Development. 38(3):282-97.

Card, D. 1998. Falling Union Membership and Rising Wage Inequality: What's the Connection? NBER Working Paper. No. 6520. http://www.nber.org/papers/w6520.

Card, D., and A. B. Krueger. 1992. Does School Quality Matter? Returns to Education and the Characteristics of Public Schools in the United States. Journal of Political Economy. 100 (1): 1-40.

Carneiro, P., and J. Heckman. 2003. Human Capital Policy. Cambridge, MA: MIT Press.

Chamarbagwala, R. 2006. Economic Liberalization and Wage Inequality in India. World Development. 34(12):1997-2015. 
Chen, C., M. Mourshed, and A. Grant. 2013. The $\$ 250$ Billion Question: Can China Close the Skills Gap? McKinsey \& Company. http://mckinseyonsociety.com/can-chinaclose-the-skills-gap.

Chen, Y., and S. Feng. 2013. Access to Public Schools and the Education of Migrant Children in China. China Economic Review. 26:75-88.

Chenoy, D. 2012. Chapter 18: Skill Development in India-A Transformation in the Making. In Infrastructure Development Finance Company, India Infrastructure Report 2012, Private Sector in Education. http://www.idfc.com/foundation/policy_advocacy/ india_infrastructure_report.htm.

Cho, H., P. Glewwe, and M. Whitler. 2012. Do Reductions in Class Size Raise Students' Test Scores? Evidence from Population Variation in Minnesota's Elementary Schools. Economics of Education Review. 31(3): 77-95.

Chung, S. 2011. Innovation, Competitiveness, and Growth: Korean Experiences. Annual Bank Conference on Development Economics (ABCDE).

Confederation of Indian Industry (CII). 2014. Skill Challenges of Informal Sector in India. Focus of the Month. Confederation of Indian Industry. http://www.ies.gov.in/pdfs/ publications-sunita-sanghi-kuntal-sensarma.pdf.

CII. PeopleStrong, and Wheebox. 2013. The India Skills Report 2014. https://wheebox.com/ wheebox/resources/IndiaSkillsReport.pdf.

Colclough, C., G. Kingdon, and H. A. Patrinos. 2009. The Pattern of Returns to Education and its Implications. Research Consortium on Educational Outcomes \& Poverty. Policy Brief. No. 4. http://ceid.educ.cam.ac.uk/publications/pb4.pdf.

Collins, S. M. 2007. Economic Growth in South Asia: A Growth Accounting Perspective. In A. Ahmed and E. Ghani, eds. South Asia: Growth and Regional Integration. Washington, DC: World Bank.

Communist Party of China News. 2014. Enlarge and Deepen the Reform of the Vocational Education Run, 25 June. http://cpc.people.com.cn/n/2014/0625/c8722825196326.html.

Cunha, F., J. J. Heckman, L. Lochner, D. V. Masterov. 2006. Interpreting the Evidence on Life Cycle Skill Formation. Handbook of the Economics of Education. 1:697-812.

Das, J., and T. Zajonc. 2008. India Shining and Bharat Drowning: Comparing Two Indian States to the Worldwide Distribution in Mathematics Achievement. Policy Research Working Paper. No. 4644. Washington, DC: World Bank.

De Paola, M., M. Ponzo, and V. Scoppa. 2009. Class Size Effects on Student Achievement: Heterogeneity across Abilities and Fields. Education Economics. 21(2): 135-153.

Desai, S. B., A. Dubey, B. L. Joshi, M. Sen, A. Shariff, and R. Vanneman. 2010. Human Development in India. New Delhi: Oxford University Press.

Di Gropello, E., and C. Sakellariou. 2010. Industry and Skill Wage Premiums in East Asia. World Bank Policy Research Working Paper. No. 5379.

Di Gropello, E., H. W. Tan, and P. Tandon, P. 2010. Skills for the Labor Market in the Philippines. World Bank Publications.

Dittrich, J. 2010. Can Indonesia Learn Something from the German Model of TVET Teacher Education. Educationist. IV(2): 67-77. 
Ding, X., S. Yang, and W. Ha. 2013. Trends in the Mincerian Rates of Return to Education in Urban China: 1989-2009. Frontiers of Education in China. 8(3):378-97.

Ding, X. H., Q. M. Yu, and H. X. Yu. 2012. Research on Rates of Return to Education of Chinese Urban Residents and its Changes in this Century. Exploring Education Development. 11:1-6.

Drèze, J., and A. Sen. 2013. An Uncertain Glory: India and its Contradictions. Princeton University Press.

Dundar, H., T. Beteille, M. Riboud, and A. Deolalikar. 2014. Student Learning in South Asia: Challenges, Opportunities, and Policy Priorities. World Bank Publications.

Dutz, M., and S. O'Connell. 2013. Productivity, Innovation and Growth in Sri Lanka: An Empirical Investigation. World Bank Policy Research Working Paper. No. 6354.

Ehrenberg, R. G., D. J. Brewer, A. Gamoran, and J. D. Willms. 2001. Class size and student achievement. Psychological Science in the Public Interest. 2(1):1-30.

Eichengreen, B., Park, D., and Shin, K. 2013. Growth Slowdowns Redux: New Evidence on the Middle-income Trap. Working Paper. No. 18673. National Bureau of Economic Research.

Fang, H., K. N. Eggleston, J. A. Rizzo, S. Rozelle, and R. J. Zeckhauser. 2012. The Returns to Education in China: Evidence from the 1986 Compulsory Education Law. NBER Working Paper. No. 18189. http://www.nber.org/papers/w18189.

Farrell, D., and A. Grant. 2005. Addressing China's Looming Talent Shortage. McKinsey \& Company. http://www.mckinsey.com/insights/china/addressing_chinas_looming_ talent_shortage.

Feenstra, R. C., R. Inklaar, and M. I. P. Timmer. 2013. The Next Generation of the Penn World Table. www.ggdc.net/pwt.

Findlay, R. 1978. Relative Backwardness, Direct Foreign Investment, and the Transfer of Technology: A Simple Dynamic Model. Quarterly Journal of Economics. 92(1):1-16.

Fleisher, B., H. Li, and M. Q. Zhao. 2010. Human Capital, Economic Growth, and Regional Inequality in China. Journal of Development Economics. 92(2):215-31.

Fleisher, B. M., Y. Hu, H. Li, and S. Kim. 2011. Economic Transition, Higher Education and Worker Productivity in China. Journal of Development Economics. 94(1):86-94. http://www.sciencedirect.com/science/article/pii/S0304387810 000039.

Fleisher, B., and X. Wang. 2001. Efficiency Wages and Work Incentives in Urban and Rural China. Journal of Comparative Economics. 29:645-62.

- 2003. Potential Residual and Relative Wages in Chinese Township and Village Enterprises. Journal of Comparative Economics. 31:429-43.

- 2004. Skill Differentials, Return to Schooling, and Market Segmentation in a Transition Economy. Journal of Development Economics. 73:715-28.

Fleming, D., and H. Soborg. 2012. Malaysia's Skill Development and the Middle Income Trap, ILERA Conference Paper. Roskilde University, Denmark.

Fox, L., and Y. Zhao. 2002. China's Labor Market Reform: Performance and Prospects. Background paper for the 2002 Country Economic Memorandum. World Bank, Washington, DC. 
Fredriksen, B., and J. P. Tan, eds. 2008. An African Exploration of the East Asian Education Experience. Washington, DC: World Bank.

Freeman, R. B. 1993. How much has de-unionization contributed to the rise in male earnings inequality? In S. H. Danziger and P. Gottschalk, eds. Uneven Tides. New York: Russel Sage.

Freeman, R. B., and L. F. Katz. 1994. Rising Wage Inequality: the United States vs. Other Advanced Countries. In R. B. Freeman, ed. Working under Different Rules. New York: Russel Sage Foundation.

Freeman, R. B., and L. F. Katz 1995. Differences and Changes in Wage Structures. Chicago: University of Chicago Press.

Fulford, S. 2014. Returns to Education in India. World Development. 59:434-50.

Gallagher, M., A. Hasan, M. Canning, H. Newby, L. Saner-Yiu, and I. Whitman. 2009. OECD Reviews of Tertiary Education: China. Paris: Organisation for Economic Co-operation and Development.

Gerschenkron, A. 1962. Economic Backwardness in Historical Perspective. Cambridge, MA: The Belknap Press.

Ghai, D., ed. 1999. Social Development and Public Policy. A Study of Some Successful Experiences. Geneva: United Nations Research Institute for Social Development (UNRISD).

Ghazali, G. (2012). Mainstreaming skills training: Malaysia's skills and the future. In OECD-LEED (Eds.), Skills development pathways in Asia (pp. 67-70). Paris: OECD Publishing.

Glewwe, P., and M. Kremer. 2006. Schools, Teachers, and Education Outcomes in Developing Countries. Handbook of the Economics of Education. 2: 945-1017.

Global Campaign for Education (GCE) and Education International. 2012. Every Child Needs a Teacher: Closing the Trained Teacher Gap. Johannesburg: GCE. http:// www.campaignforeducation.org/docs/reports/ECNAT\%20Report_RGB.pdf.

Goldhaber, D. D., and D. J. Brewer. 1999. Why Don't Schools and Teacher Seem to Matter?: Assessing the Impact of Unobservables on Education Production. Journal of Human Resources. 32(3):505-523.

Gosper, M., and D. Ifenthaler, eds. 2014. Curriculum Models for the 21st Century Using Learning Technologies in Higher Education. New York: Springer.

Government of India. 2008. Eleventh Five Year Plan, 2007-2012. Delhi: Planning Commission.

- 2009. Right of Children to Free and Compulsory Education Act, 2009. Ministry of Human Resource Development, Department of School Education and Literacy. http://ssa.nic.in/ quality-of-education/right-of-children-to-free-and-compulsoryeducation-act-2009.

- 2011a. Employment and Unemployment Situation in India 2009-10, NSS 66th Round, NSS Report. No. 537. Delhi: Ministry of Statistics and Programme Implementation, National Sample Survey Office.

_. 2011b. National Institute of Open Schooling-Distance Vocational Education Programs, Prospectus. Uttar Pradesh: Ministry of Human Resource Development.

_. 2012a. Twelfth Five-Year Plan, 2012-2017. Delhi: Planning Commission. http://12thplan.gov.in.

_. 2012b. National Council of Educational Research and Training. http://www.ncert.nic. in/ finalguidelines.pdf. 
_. 2012c. Vocational Education. Minister of Human Resource Development. http://mhrd.gov.in/voc_edu

Government of Singapore. 2008. Learning for Life: Advancing with Skill: Annual Report 2007/08. Singapore: Singapore Workforce Development Authority.

_. 2013. Right to Education. http://www.indg.in/primary-education/ policiesandschemes/right-to-education-bill.

Griffin, K., and Z. Renwei. 1988. Chinese Household Income Project, 1988. ICPSR09836-v2. Michigan: Inter-university Consortium for Political and Social Research.

Gustafsson, B., and S. Li. 2000. Economic Transformation and the Gender Earnings Gap in Urban China. Journal of Population Economics. 13:305-329.

Han, J., R. Liu, and J. Zhang. 2012. Globalization and Wage Inequality: Evidence from Urban China. Journal of International Economics. 87:288-297.

Hanushek, E. A. 2011. The Economic Value of Higher Teacher Quality. Economics of Education Review. 30(3): 466-479.

Hanushek, E. A., S. Guido, S. Wiederhold, and L. Woessman. 2013. Returns to skills around the world: Evidence from PIAAC. OECD Education Working Paper. No. 101. OECD Publishing.

Hanushek, E. A., J. F. Kain, and S. G. Rivkin. 2009. New Evidence about Brown v. Board of Education: The Complex Effects of School Racial Composition on Achievement. Journal of Labor Economics. 27(3): 349-383.

Hanushek, E. A., and D. D. Kimko. 2000. Schooling, Labor Force Quality, and the Growth of Nations. American Economic Review. 90 (5): 1184-1208.

Hanushek, E. A., and S. G. Rivkin. 2006. Teacher quality. Handbook of the Economics of Education. 2 (2006): 1051-1078.

Hanushek, E. A., G. Schwerdt, S. Wiederhold, and L. Woessmann. 2015. Returns to Skills around the World: Evidence from PIAAC. European Economic Review. 73: 103-130.

Hanushek, E. A., and L. Woessmann. 2007. The Role of Education Quality for Economic Growth. World Bank Policy Research Working Paper. No. 4122. Washington, DC: World Bank.

2008a. Assessing National Achievement Levels in Education. National Assessments of Educational Attainment, Vol. 1. Washington, DC: World Bank.

2008b. The Role of Cognitive Skills in Economic Development. Journal of Economic Literature. 46(3): 607-668.

2011. The Economics of International Differences in Educational Achievement. Handbook of Education Economics. 3(2):89-200.

2012. Do Better Schools Lead to More Growth? Cognitive Skills, Economic Outcomes, and Causation. Journal of Economic Growth. 17(4): 267-321.

Harris, D. N., and T. R. Sass. 2011. Teacher Training, Teacher Quality and Student Achievement. Journal of Public Economics. 95(7):798-812.

Hasan, R., and K. R. Jandoc. 2012 Labor Laws and the Firm Size Distribution in Indian Manufacturing. In J. Bhagwati and A. Panagariya, eds. Reforms and Economic Transformation in India. Oxford University Press. 
Hasan, R., S. Lamba, and A. S. Gupta. 2013. Growth, Structural Change, and Poverty Reduction: Evidence from India. South Asia Working Paper Series. No. 22. Manila: Asian Development Bank.

Heckman, J.J., J. Stixrud, and S. Urzua. 2006. The Effects Of Cognitive and Noncognitive Abilities On Labor Market Outcomes and Social Behavior. Journal of Labor Economics. 24(3): 411-482.

Herrendorf, B., R. Rogerson, and A. Valentinyi. 2013. Growth and Structural Transformation. CEPR Discussion Paper. No. DP9370.

Hsieh, C. T., and P. J. Klenow. 2009. Misallocation and Manufacturing TFP in China and India. The Quarterly Journal of Economics. 124(4):1403-48.

Inchauste, G., and J. Saavedra-Chanduvi. 2014. Opportunity Knocks: Deepening Our Understanding of Poverty Reduction. In G. Inchauste, J. P. Azevedo, B. EssamaNssah, S. Olivieri, T. V. Nguyen, J. Saavedra-Chanduvi, and H. Winkler, eds. Understanding Changes in Poverty. Washington, DC: World Bank.

Institute for the Study of Labor, Australian National University, and Beijing Normal University. 2013. Longitudinal Survey on Rural-Urban Migration in China, 2008-2009.

International Labour Organization (ILO). 2011a. A Skilled Workforce for Strong, Sustainable and Balanced Growth. Geneva. http://www.ilo.org/wcmsp5/groups/public/--dgreports/---integration.

— 2011b. Skills for Employment Policy Brief: Formulating a National Policy on Skills Development. Geneva. http://ilo.org/wcmsp5/groups/public/---ed_emp/---ifp_ skills/documents/publication/wcms_167172.pdf.

- 2011c. TVET Centres in Indonesia. Pathways to Revitalization. Jakarta.

—. 2014. Labour Migration. Geneva. http://www.ilo.org/beijing/areas-of-work/labourmigration/lang--en/index.htm

Jeong, J.-H., K. -Y. Lee, and G. Choi. 2004. Change and Factor Analysis of the Wage Gap Between Educational Attainment. Korea Labor Institute.

Johanson, R. 2009. Review of National Training Funds. Social Protection. Discussion Paper. No. 0922. Washington: World Bank.

Jones, G., and D. Ramchand. 2013. Education and Human Capital Development in the Giants of Asia. Asian-Pacific Economic Literature. 27(1):40-61.

Jongwanich, J. 2007. Workers' Remittances, Economic Growth and Poverty in Developing Asia and the Pacific Countries. United Nations Publications.

Jongwanich, J. 2007. Workers' Remittances, Economic Growth and Poverty in Developing Asia and the Pacific Countries. UNESCAP Working Paper. (WP/07/01).

Kaspos, S. 2006. The Gender Wage Gap in Bangladesh. ILO Asia-Pacific Working Paper Series. (May).

Katz, L. F., and K. M. Murphy. 1992. Changes in Relative Wages, 1963-1987: Supply and Demand Factors. The Quarterly Journal of Economics. 107(1):35-78.

Kijima, Y. 2006. Why Did Wage Inequality Increase? Evidence from Urban India 1983-99. Journal of Development Economics. 81:97-117.

Kim, Sookon, Kim, Jae-won and Ihm, Chosun (1990). 'Republic of Korea', in Asian Development Bank, Human Resources and Economic Development: Selected Country Studies. Manila. 
Klenow, P. J., and A. Rodriguez-Clare. 1997. Economic Growth: A Review Essay. Journal of Monetary Economics. 40(3):597-617.

Knight, J., and L. Song. 2003a. Chinese Peasant Choices: Migration, Rural Industry or Farming. Oxford Development Studies. 31(2):123-48.

2003b. Increasing Urban Wage Inequality in China. Economics of Transition. 11(4):597-619.

Knight, J., L. Song, and J. Huaibin. 1999. Chinese Rural Migrants in Urban Enterprises: Three Perspectives. The Journal of Development Studies. 35(3):73-104.

Konings, J., and S. Vanormelingen. The Impact of Training on Productivity and Wages: Firmlevel Evidence. Review of Economics and Statistics. 97.2 (2015): 485-497.

Krueger A. B. 1999. Experimental Estimates of Education Production Functions. Quarterly Journal of Economics. 114: 497-532.

Krueger, A., and M. Lindahl. 2001. Education and Growth: Why and for Whom? Journal of Economic Literature. 39(4):1101-36.

Krusell, P., L. E. Ohanian, J. V. Rios-Rull, and G. L. Violante. 2000. Capital Skill Complementarity and Inequality: A Macroeconomic Analysis. Econometrica. 68 (55): 1029-1053.

Lai, F., E. Sadoulet, and A. De Janvry. 2011. The Contributions of School Quality and Teacher Qualifications to Student Performance Evidence from a Natural Experiment in Beijing Middle Schools. Journal of Human Resources. 46(1):123-53.

Lee, C. J. 2008. Chapter 5: Education in the Republic of Korea: Approaches, Achievements, and Current Challenges. In B. Fredriksen and J. P. Tan, eds. An African Exploration of the East Asian Education Experience. Washington, DC: World Bank.

Lee, D. S. 1999. Wage inequality in the United States during the 1980s: Rising Dispersion or Falling Minimum Wage. The Quarterly Journal of Economics. 114(3): 977-1023.

Lee, J.-W. 2001. Education for Technology Readiness: Prospects for Developing Countries. Journal of Human Development and Capabilities. 2(1):115-51.

- 2003. Economic Growth and Human Development in the Republic of Korea: 1945-1992. New York. (No. HDOCPA-1997-02). Human Development Report Office, United Nations Development Programme.

. 2014a. India's Chinese Dream. Project Syndicate, 24 July. http://www.projectsyndicate.org/commentary/lee-jong-wha-outlines-how-india-can-replicate-chinas-economic-success.

—. 2014b. Education and Opportunity. Project Syndicate, 11 September. http://www. project-syndicate.org/commentary/lee-jong-wha-shows-why-improvingacademic-access-and-quality-should-be-a-top-priority-for-world-leaders.

Lee, J.-W. and R. Francisco. 2012. Human Capital Accumulation in Emerging Asia, 19702030. Japan and the World Economy. 24(2):76-86.

Lee, J. -W. and D. Wie. 2015a. Technological Change, Skill Demand, and Wage Inequality: Evidence from Indonesia. World Development. 67, 238-250.

—. 2015b. Wage Structure, and Gender Earnings Differentials in China and India. Korea University and National Graduate Institute for Policy Studies. Working Paper.

- 2017. Returns to Education and Skills in the Labor Market: Evidence from Japan and Korea. Asian Economic Policy Review. 12(1): 139-160. 
Lee, S., and B. A. Malin. 2013. Education's Role in China's Structural Transformation. Journal of Development Economics. 101:148-66.

Lee, Y.-H. 2009. Vocational Education and Training in the Process of Industrialization. Understanding Korean Educational Policy. Vol. 5. Seoul: Educational Development Institute.

Leong, C. H., and S. H. Tan. 1997. Malaysia: Social Development, Poverty Reduction, and Economic Transformation. In S. Mehrotra and R. Jolly, eds. Development with a Human Face. Oxford: Clarendon Press.

Lewis, A. 1972. Reflections on Unlimited Labour. In L. Di Marco, ed. International Economics and Development. New York: Academic Press.

Li, H., and L. Huang. 2009. Health, Education, and Economic Growth in China: Empirical Findings and Implications. China Economic Review. 20(3):374-87.

Li, S., and S. Ding 2003. Long-term Change in Private Returns to Education in Urban China. Social Sciences in China. 6:58-72.

Li, W., T. Mengistae, and L.C. Xu. 2011. Diagnosing Development Bottlenecks: China and India. Oxford Bulletin of Economics and Statistics Special Issue: Economic Growth in China: Productivity and Policy. 73(6):722-52.

Liang, X., and S. Chen. 2014. Developing Skills for Economic Transformation and Social Harmony in China: A Study of Yunnan Province. Directions in Development; Human Development. Washington, DC. http://documents.worldbank.org/curated/en/2013/ 01/18437972/developing-skills-economic-transformation-social-harmony-chinastudy-yunnan-province.

Liu, C., L. Zhang, R. Luo, S. Rozelle, and B. Sharbono. 2009. Development Challenges, Tuition Barriers and High School Education in China. Asia Pacific Journal of Education. 29(4):503-520.

Liu, S., and A. Hu. 2013. Demographic Change and Economic Growth: Theory and Evidence from China. Economic Modelling. 35: 71-77.

Lucas, R. 1988. On the Mechanics of Economic Development. Journal of Monetary Economics. 22(1): 3-42.

—. 1993. Making a Miracle. Econometrica. 61(2): 251-272.

Luo, X., and T. Terada. 2009. Education and Wage Differentials in the Philippines. World Bank Policy Research Working Paper. No. 5120.

Ma, Y. 2009. Skills development to support rebalancing employment growth in China. Paris: Organisation for Economic Co-operation and Development.

Machin, S., and Van Reenen, J. 1998. Technology and changes in skill structure: Evidence from Seven OECD countries. The Quarterly Journal of Economics. 113(4), 1215-1244.

Maclean, R., S. Jagannathan, and J. Sarvi. 2013. Skills Development for Inclusive and Sustainable Growth in Developing Asia-Pacific. Manila: Asian Development Bank / Springer Publications (Springer).

Mankiw, N. G., D. Romer, and D. N. Weil. 1992. A Contribution to the Empirics of Economic Growth. The Quarterly Journal of Economics. 107(2):407-37.

Mansuri, G. 2006. Migration, School Attainment, and Child Labor: Evidence from Rural Pakistan. World Bank Policy Research Working Paper. No. 3945. 
Martinez-Fernandez, C., and Powell, M. 2010. Employment and Skills Strategies in Southeast Asia: Setting the Scene (No. 2010/1). OECD Publishing.

Mason, E., M. J. Kim, D. H. Perkins, K.S. Kim, and D. C. Cole. 1980. The Economic and Social Modernization of the Republic of Korea. Cambridge, MA: Harvard University Press.

McKinsey Global Institute. 2012a. Manufacturing the Future: The Next Era of Global Growth and Innovation. http://www.mckinsey.com/insights/manufacturing/the_ future_of_manufacturing.

_ 2012b. The World at Work: Jobs, Pay, and Skills for 3.5 Billion People. http://www. mckinsey.com/insights/employment_and_growth/the_world_at_work.

Mehrotra, S., ed. 2014. India's Skills Challenge. Reforming Vocational Education and Training to Harness the Demographic Dividend. New Delhi: Oxford University Press.

Mehrotra, S., and M. Biggeri, eds. 2007. Asian Informal Workers. Global Risks, Local Protection. London: Routledge.

Mehrotra, S., S. Gandhi, and Kamaladevi. Forthcoming. China's TVET System: Lessons for India. Economic and Political Weekly.

—. 2012b. Joblessness and Informalization: Challenges to Inclusive Growth in India. IAMR Occasional Paper. No. 9/2012. New Delhi: Institute of Applied Manpower Research.

- 2014. Is India's TVET System Responding to the Challenge of Rapid Economic Growth. In S. Mehrotra, ed. India's Skills Challenge. Reforming Vocational Education and Training to Harness the Demographic Dividend. New Delhi: Oxford University Press.

Mehrotra, S., and D. Ghosh. 2014. The International Experience with National Training Funds: Lessons for India. Economic and Political Weekly. 49 (26-27).

Mehrotra, S., and R. Jolly, eds. 1997. Development with a Human Face: Experiences in Social Achievement and Economic Growth. Oxford: Clarendon Press.

Mehrotra, S., A. Kalaiyarasan, K. N. Kumra, and R. Raman. (2015). Vocational training in India and the duality principle: A case for evidence-based reform. Prospects 45(2): 259-273.

Mehrotra, S. 2015. The Employability of Tertiary Education Graduates in India. In The Higher Education Report for India. New Delhi: National University of Educational Planning and Administration.

Mehrotra, S., I.-W. Park, and H.-J. Baek. 1997. Social Development in a Growing Economy: the role of the state in Republic of Korea. In S. Mehrotra and R. Jolly, eds. Development with a Human Face. Oxford: Clarendon Press.

Mehrotra S., P. Saha, A. Gandhi, K. Devi, and S. Sinha. 2013. Low Female Employment in a Period of High Growth: Insights from Primary Survey in Uttar Pradesh and Gujarat. IAMR Report. No. 9/2013. New Delhi: Institute of Applied Manpower Research.

Mehrotra S., A. Gandhi, and B. K. Sahoo. 2012a. Organised and Unorganised Employment in the Non-Agricultural Sectors in the 2000s. IAMR Occasional Paper. No. 6/2012. New Delhi: Institute of Applied Manpower Research.

Mehrotra, S., and S. Sinha. Forthcoming. Why is Women's Participation in the Labour Force Falling? In P. Jha and A. Mishra, eds. Women in India's Workforce. New Delhi: Sage. 
Mehta, A., and R. Hasan. 2012. Effects of Trade and Services Liberalization on Wage Inequality in India. International Review of Economics and Finance. 23:75-90.

Meng, X. 2012. Labor Market Outcomes and Reforms in China. The Journal of Economic Perspectives. 6(4):75-101.

Menon, M., and Y. M. Rodgers. 2008. International Trade and the Gender Wage Gap: New Evidence from India's Manufacturing Sector. World Development. 37(5):965-81.

Meroni, E. C., E. Vera-Toscano, and P. Costa. 2015. Can Low Skill Teachers Make Good Students? Empirical Evidence from PIAAC and PISA. Journal of Policy Modeling. 37(2): 308-323.

Mincer, J. A. 1974. Schooling and Earnings. Schooling, Experience and Earnings. New York. NBER, 41-63.

Mishel, L., and R. Rothstein, eds. 2002. The Class Size Debate. Washington, DC: Economic Policy Institute.

Mishra, V., and R. Smyth. 2014. Chapter 9: Returns to Education in China's Urban Labour Market: Evidence from Matched Employer-Employee Data for Shanghai. In Z. Cheng, W. Zhiming, M. Wang, and J. Chen, eds. Urban China in the New Era: Market Reforms, Current State, and the Road Forward. Heidelberg: Springer.

Muralidharan, K., and M. Kremer. 2008. Public and Private Schools in Rural India. In R. Chakrabarti and P. Peterson, eds. School Choice International: Exploring Public-Private Partnerships. Cambridge, MA: MIT Press.

National Council of Educational Research and Training. 2011. What Do They Know? A Summary of India's National Achievement Survey, Class V, Cycle 3 2010/11. New Delhi: NCERT.

National Education Research and Evaluation Center. 2009. National Assessment of Achievement of Grade 4 Pupils. Colombo.

Nelson, R. R., and E. S. Phelps. 1966. Investment in Humans, Technological Diffusion, and Economic Growth. The American Economic Review. 56(1-2): 69-75.

Organisation for Economic Co-operation and Development (OECD). 2012a. PISA 2012 Results in Focus: What 15-year-olds Know and What They Can Do with What They Know: Key Results from PISA 2012. Paris. http://www.oecd.org/pisa/keyfindings/ pisa-2012-results.htm.

_. 2012b. Education at a Glance 2012. Paris. http://www.oecd.org/edu/eag2012.htm.

_. 2013a. Education at a Glance. OECD Indicators. Paris: OECD Publishing.

_. 2013b. OECD Skills Outlook 2013: First Results from the Survey of Adult Skills. Paris.

Ojha, V. P., and B. K. Pradhan. 2006. Human Capital Formation and Economic Growth in India: A CGE Analysis. Policy. 1:28. http://www.isid.ac.in/.

Okada, A. 2012. Skills Development for Youth in India: Challenges and Opportunities. Journal of International Cooperation in Education. 15(2):169-93.

Ou, X., and J. Liu. 2007. China's Industrial Development and Industrial Policy. Beijing: Xinhua Press.

Panagariya, A. 2008. India: The Emerging Giant. New York: Oxford University Press.

Panth, B. 2013. Skills Training and Workforce Development with Reference to Underemployment and Migration. In R. Maclean, S. Jagannathan, and J. Sarvi, eds. Skills Development for Inclusive and Sustainable Growth in Developing Asia-Pacific. New York: Springer. 
Park, A., Y. Wu, and Y. Du. 2012. Informal Employment in Urban China: Measurement and implications. Working Paper. No. 77737. Washington, DC: World Bank. http:// documents.worldbank.org/curated/en/2012/07/17718498/informal-employmenturban-china-measurement-implications.

Park, J. 2012. Total Factor Productivity Growth for 12 Asian Economies: The Past and the Future. Japan and the World Economy. 24(2):114-27.

Peet, E. D., G. Fink, and W. 2015. Returns to Education in Low- and Middle-Income Countries: Evidence from the Living Standards and Measurement Study Surveys. Working Paper. Harvard University.

Poon, S. 2012. China's TVET: Vision and Priorities. Proceedings of the National Conference for TAFE Directors Australia - East Meets West. Perth. 6-7 September. http://www. thei.edu.hk/thei/files/file/China's\%20TVET\%20vision\%20and\%20priorities\%20 \%20SPoon\%20v\%202.pdf.

Pradhan, G., M. Upadhyay, and K. Upadhyaya. 2008. Remittances and Economic Growth in Developing Countries. The European Journal of Development Research. 20(3): 497-506.

Pratham. 2006. Annual Status of Education Report. http://www.asercentre.org.

_ 2013. Annual Status of Education Report. http://www.asercentre.org.

Psacharopoulos, G. 1994. Returns to Investment in Education: A Global Update. World Development. 22(9):1325-43.

Psacharopoulos, G., and H. A. Patrinos. 2004. Returns to Investment in Education: A Further Update. Education Economics. 12(2):111-2134.

Qiu, T., and Hudson. 2010. Private Returns to Education in Urban China. Economic Change and Restructuring. 43(2):131-50.

Qualifications Recognition. 2011. China-Description of Education and Training System. International Qualifications Database. http://www.qualificationsrecognition.ie/chinaQualityAssuranceofHigherEducationandTraining.html (accessed 1 May 2014).

Quisumbing, A., and S. McNiven. 2010. Moving Forward, Looking Back: the Impact of Migration and Remittances on Assets, Consumption, and Credit Constraints in the Rural Philippines. The Journal of Development Studies. 46(1): 91-113.

Ra, Y.-S., and Kang, S.-H. 2012. Vocational Training System for a Skilled Workforce. KDI School of Public Policy and Management. https://www.kdevelopedia.org/resource/ view/04201210100122122.do\#.VRZva2f9nIU.

Ranis, G., and F. Stewart. 2006. Successful Transition towards a Virtuous Cycle of Human Development and Economic Growth: Country Studies. Yale Economic Growth Center. Center Discussion Paper No. 943. New Haven.

Riskin, C., Z. Renwei, and L. Shi. 1995. Chinese Household Income Project, 1995. ICPSR03012-v2. Michigan: Inter-university Consortium for Political and Social Research.

Rodrik, D. 2014. Are Services the New Manufactures? Project Syndicate, 13 October. http:// www.project-syndicate.org/commentary/are-services-the-new-manufactures-bydani-rodrik-2014-10.

Romer, P. 1986. Growth Based on Increasing Returns Due to Specialization. Journal of Political Economy. 77:1002-37.

. 1990. Endogenous Technological Change. Journal of Political Economy. October: S71-S102. 
Rozelle, S. 2011. China's Human Capital Challenge and Investments in Education, Nutrition and Health. Background paper for China 2030: Building a Modern, Harmonious, and Creative High-Income Society. Washington, DC: World Bank.

Rozelle, S., X. C. Ma, L. X. Zhang, and C. F. Liu. 2009. Educating Beijing's Migrants: A Profile of the Weakest Link in China's Education System. REAP Working Paper. No. 212. Rural Education Action Program, Stanford University.

Sabharwal, M. 2013. Chapter 4: Education, Employability, Employment, and Entrepreneurship: Meeting the Challenge of the 4Es. In R. Maclean, S. Jagannathan, and J. Sarvi, eds. Skills Development for Inclusive and Sustainable Growth in Developing Asia-Pacific. New York: Springer.

Sabharwal, M., and Sharma. 2012. Chapter 19: Private Sector in Professional and Vocational Education. In Infrastructure Development Finance Company, India Infrastructure Report 2012: Private Sector in Education. http://www.idfc.com/foundation/policy_ advocacy/india_infrastructure_report.htm.

Sanghi, S., and Sensarma. 2014. Skill Challenges of Informal Sector in India. Focus of the Month. Confederation of Indian Industry. http://www.ies.gov.in/pdfs/publicationssunita-sanghi-kuntal-sensarma.pdf.

Santiago, P. 2002. Teacher Demand and Supply: Improving Teaching Quality and Addressing Teacher Shortages. OECD Publishing.

Schwab, K. and X. Sala-i-Martín. 2013. The Global Competitiveness Report 2013-2014: Full Data Edition. Geneva: World Economic Forum.

- 2014. The Global Competitiveness Report 2014-2015. Geneva: World Economic Forum. www.weforum.org/gcr.

Sellar, S., and B. Lingard. 2013. Looking East: Shanghai, PISA 2009 and the Reconstitution of Reference Societies in the Global Education Policy Field. Comparative Education 49(4):464-85.

Shi, L. 2002. Chinese Household Income Project, 2002. ICPSR21741-v1. Michigan: Interuniversity Consortium for Political and Social Research.

Shi, W. 2012. Development of TVET in China: Issues and Challenges. The Future of Vocational Education and Training in a Changing World. VS Verlag für Sozialwissenschaften 85-95.

Sharma, Y. P. 2010. Background Note to South-South Study Visit to China and India on Skills and Technical and Vocational Education and Training. 1-12 November. http://siteresources.worldbank.org/EDUCATION/ Resources/278200-1121703274255/1439264-1242337549970/ 6124382-1288297991092/ChinaNote-byWenjinWang.pdf.

Sinha, J. K., J. Abraham, and R. Vohra. 2008. India's Demographic Dilemma: Talent Challenges for the Services Sector. New Delhi: Confederation of Indian Industry and Boston Consulting Group.

Solow, R. M. 1957. Technical Change and the Aggregate Production Function. Review of Economics and Statistics. 39:312-20.

Suri, T., M. A. Boozer, G. Ranis, and F. Stewart. 2011. Paths to Success: The Relationship Between Human Development and Economic Growth. World Development. 39 (4): 506-522.

Tan, C. 2012. The Culture of Education Policy Making: Curriculum Reform in Shanghai. Critical Studies in Education. 53:153-67. 
Tan, C. 2013. Learning from Shanghai: Lessons on Achieving Educational Success. Dordrecht: Springer.

Tan, H. 2001. Do Training Levies Work? Malaysia's HRDF and Its Effects on Training and FirmLevel Productivity. Washington, DC: World Bank Institute.

Tan, H. W., and G. Batra. 1996. Enterprise Training in Developing Countries: Overview of Incidence, Determinants, and Productivity Outcomes. Private Sector Development Paper. No. 6. Washington: World Bank.

TeamLease and IIJT. 2009. The India Labour Report: The Geographic Mismatch and A Ranking of Indian States by their Labour Ecosystem. http://www.teamlease.com/ index.php?module=research\&event=india_Labour_Report.

Temple, J., and L. Woessmann. 2006. Dualism and Cross-Country Growth Regressions. Journal of Economic Growth. 11:187-228.

Topel, R. 1999. Labor Markets and Economic Growth. Handbook of Labor Economics. 2943 $-2984$.

United Nations. 2013. World Population Prospects: The 2012 Revision. New York: Department of Economic and Social Affairs, Population Division. http://esa.un.org/wpp/.

United Nations Development Programme (UNDP). 1990. Human Development Report 1990, Concept and Measurement of Human Development. New York. http://hdr.undp.org/ en/reports/global/hdr1990.

— 2013. Human Development Report 2013, The Rise of the South: Human Progress in a Diverse World. New York. http://hdr.undp.org/en/2013-report.

United Nations Educational, Scientific and Cultural Organization (UNESCO). 2012. Youth and Skills: Putting education to work. Education for All 2012 Report. France.

—. 2014. Teaching and Learning: Achieving Quality for all. Education for All 2013/4 Report. France.

United Nations Educational, Scientific and Cultural Organization Institute of Statistics (UIS). 2015. UIS database.

_. 2006. Teachers and Educational Quality: Monitoring Global Needs for 2015 (Vol. 253). UNESCO Institute of Statistics.

- 2015. UIS database.

UNESCO-UNEVOC International Centre. 2012a. TVET in Indonesia. www.unevoc.unesco. org.

- 2012b. TVET in the Philippines.

—. 2012c. TVET in Vietnam. www.unevoc.unesco.org

—. 2013a. TVET in Malaysia. www.unevoc.unesco.org

_. 2013b. TVET in Nepal. www.unevoc.unesco.org

—. 2013c. TVET in Sri Lanka. www.unevoc.unesco.org

Vogel, A., and Korinek, K. 2012. Passing by the Girls? Remittance Allocation for Educational Expenditures and Social Inequality in Nepal's Households 2003-2004. International Migration Review. 46(1):61-100.

Walker, M. 2011. PISA 2009 Plus Results: Performance of 15-year-olds in Reading, Mathematics and Science for 10 Additional Participants. Melbourne: ACER Press. 
Wang, L., and T. Holland. 2011. In Search of Educational Equity for the Migrant Children of Shanghai. Comparative Education. 47(4):471-87.

Wang, M. J., and C. J. Yue. 2009. Estimation and Comparison on Individual Returns to Schooling: A Semiparametric Approach. Statistical Research. 26(6):51-9.

Wang, R., and K. B. Wu. 2008. Urban Service Delivery and Governance in Education in Five Chinese Cities. Washington, DC: World Bank.

Wolf, Jr., C., S. Dalal, J. DaVanzo, E. V. Larson, A. Akhmedjonov, H. Dogo, M. Huang, and S. Montoya. 2011. China and India, 2025: A Comparative Assessment. Santa Monica: RAND National Defense Research Institute.

World Bank. 2006. Secondary Education in India: Investing in the Future. Washington, DC: Human Development Unit.

- 2007. China's Modernizing Labor Market: Trends and Emerging Challenges. Washington, DC: http://documents.worldbank.org/curated/en/2007/08/9858145/ chinas-modernizing-labor-market-trends-emerging-challenges.

_ 2010. Skills for Labour Market in the Philippines. Washington DC.

_. 2011a. More and Better Jobs in South Asia. Washington, DC.

- 2011b. Thailand Social Monitor: Towards a Competitive Higher Education System in a Global Economy. Washington DC.

- 2012. China 2030: Building a Modern, Harmonious, and Creative High-Income Society. http://documents.worldbank.org/curated/en/2013/03/17494829/

_. 2013a. Bangladesh Education Sector Review. Report 80613-BD, Human Development Sector, South Asia Region. Washington, DC.

_. 2013b. Bangladesh Enterprise-based Skills Survey. Washington, DC.

_. 2013. Jobs Statistical Tables. World Development Report 2013.

_. 2014. Building Skills for Economic Growth and Competitiveness in Sri Lanka. Washington, DC.

_. 2015a. World Development Indicators Online. http://databank.worldbank.org.

_. 2015b. Global Monitoring Report 2014/2015: Ending Poverty and Sharing Prosperity. Washington, DC.

Xu, B. 2000. Multinational Enterprises, Technology Diffusion, and Host Country Productivity Growth. Journal of Development Economics 62(2):477-93.

Xu, B., and W. Li. 2008. Trade, Technology, and China's Risking Skill Demand. Economics of Transition. 16(1):59-84.

Yang, D. 2008. International Migration, Remittances, and Household Investment: Evidence from Philippine Migrants' Exchange Rate Shocks. The Economic Journal. 118(528):591-630.

Yao, Y. 2013. The Chinese Growth Miracle. Handbook of Economic Growth. 2(B):943-1031.

Zhang, J., J. Han, P. W. Liu, and Y. Zhao. 2008. Trends in the Gender Earnings Differential in Urban China, 1988-2004. Industrial and Labor Relations Review. 61(2):224-43.

Zhang, J., Y. Zhao, A. Park, and X. Song. 2005. Economic Returns to Schooling in Urban China, 1988 to 2001. Journal of Comparative Economics. 33(4):730-52. 
Zhong, H. 2011. Returns to Higher Education in China: What is the Role of College Quality? China Economic Review. 22(2):260-75. http://www.sciencedirect.com/science/ article/pii/S1043951X11000228.

Ziesemer, T. H. 2009. Worker Remittances and Growth: The Physical and Human Capital Channels. Jahrbuecher fuer Nationaloekonomie und Statistik. 743-773.

—. 2012. Worker Remittances, Migration, Accumulation and Growth in Poor Developing Countries: Survey and Analysis of Direct and Indirect Effects. Economic Modelling. 29(2):103-118. 


\section{Human Capital Development in South Asia \\ Achievements, Prospects, and Policy Challenges}

Human capital is an important factor for economic growth in South Asia. Between 1981 and 2010, human capital contributed about $22 \%$ of annual gross domestic product per worker growth in India. During the same period, it contributed around 21\% in Bangladesh, and 16\% in Sri Lanka. However, education and skills remain the binding constraint. Raising the quality of education and skills in South Asia's workforce can play a critical role in catching up to the level of development of the People's Republic of China, the Republic of Korea, and other successful Southeast Asian economies. This study reviews the development of human capital in South

Asia and analyzes contributing factors to human development including policies and strategies that countries in South Asia follow.

\section{About the Asian Development Bank}

ADB's vision is an Asia and Pacific region free of poverty. Its mission is to help its developing member countries reduce poverty and improve the quality of life of their people. Despite the region's many successes, it remains home to a large share of the world's poor. ADB is committed to reducing poverty through inclusive economic growth, environmentally sustainable growth, and regional integration.

Based in Manila, ADB is owned by 67 members, including 48 from the region. Its main instruments for helping its developing member countries are policy dialogue, loans, equity investments, guarantees, grants, and technical assistance. 